UNIVERSIDADE DE SÃO PAULO

FACULDADE DE FILOSOFIA, LETRAS E CIÊNCIAS HUMANAS

DEPARTAMENTO DE ANTROPOLOGIA

PROGRAMA DE PÓS-GRADUAÇÃO EM ANTROPOLOGIA SOCIAL

\title{
Aparições de Nossa Senhora: \\ Mensagens e Peregrinações na contemporaneidade
}

\author{
Lilian Maria Pinto Sales
}

SÃo PAULO

2008 
UNIVERSIDADE DE SÃO PAULO

FACULDADE DE FILOSOFIA, LETRAS E CIÊNCIAS HUMANAS

DEPARTAMENTO DE ANTROPOLOGIA

PROGRAMA DE PÓS-GRADUAÇÃO EM ANTROPOLOGIA SOCIAL

Orientadora: Profa Dra Paula Montero

\title{
Aparições de Nossa Senhora: \\ Mensagens e Peregrinações na contemporaneidade
}

\author{
Lilian Maria Pinto Sales
}

Tese apresentada ao Programa de Pós-graduação em Antropologia Social, do Departamento de Antropologia Social da Faculdade de Filosofia, Letras e Ciências Humanas da Universidade de São Paulo

SÃO PAULO

2008 


\section{Resumo}

Realizamos neste trabalho uma análise das aparições de Nossa Senhora no Brasil, buscando compreender o processo social e simbólico que sustenta a formação de convicções coletivas em torno das aparições que sempre tem seu início em testemunhos pessoais sobre visões de Nossa Senhora. Para isso partimos do estudo de caso realizado nas aparições de Maria na cidade de Jacareí, interior de São Paulo.

Demonstramos o processo de construção destas manifestações, em que fatores de diferente ordem se mostraram fundamentais. Entre eles destacamos: as relações e conexões estabelecidas entre os atores e grupos envolvidos - inserindo a aparição numa "rede" de manifestações marianas -; a peregrinação entre elas; a centralidade do movimento católica Renovação Carismática - na organização dos eventos, disseminação de idéias e práticas e na modelagem simbólica dos fenômenos -; o papel desempenhado pela Igreja Católica - na produção de idéias e crenças que servem como fonte de legitimidade para as aparições -; a modelagem simbólica das aparições - fundamental para a atribuição de legitimidade ao fenômeno -, e a presença de elementos simbólicos de longa duração. Cada um desses temas foi desenvolvido ao longo dos quatro capítulos que compõem essa tese.

Palavras chave: aparições de Nossa Senhora; Renovação Carismática Católica, peregrinações, simbologia mariana; Igreja Católica. 


\section{Abstract}

The thesis analyses Our Lady’s appearances in Brazil, trying to understand the social and symbolic process supporting the creation of collective beliefs about these appearances, a process that always start with personal witness about the appearances of Our Lady. In order to analyze that, we realize a case study in the city of Jacareí, São Paulo state.

The thesis reveals the process in which these appearances occur, where different factors are fundamental. Among them we shall focus: 1) the relations and connections involving individuals and groups, inserting the apparitions in a net of Mary's demonstrations, like pilgrimages; 2) the Catholic Church role in the production of ideas and beliefs which give legitimacy to the appearances; 3) the symbolic molding of theses appearances, which are fundamental to that legitimacy; 4) the presence of long terms symbolic elements. Each one of these topics was developed in a separate chapter. 


\section{Agradecimentos}

Agradeço à Paula Montero, pela orientação desse trabalho, acompanhando-o em todas as suas etapas, mostrando-me importantes caminhos para a minha pesquisa e a enriquecendo com suas importantes considerações.

Ao professor José Guilherme Cantor Magnani, pelas conversas e discussões que trouxeram importantes rendimentos para o meu trabalho. Também o agradeço pela participação na banca de qualificação, assim como a professora Maria Lúcia Montes, cuja atenta leitura e importantes considerações contribuiu para a aprofundamento de temas de pesquisa.

Ao CNPq, pela concessão da bolsa de doutorado, e a Capes, que financiou minha estadia de pesquisa na EHESS, onde tive acesso a importantes bibliografias e documentos sobre meu tema de pesquisa, fundamentais para a elaboração deste trabalho.

Os amigos também foram muito importantes ao longo desses anos, discutindo, ajudando, interessando-se pela minha pesquisa. Entre eles cito: Adriana, Magno, Márcia, Delcimar, Ana Reis, Eliabe, Cíntia, Ronaldo e tantos outros de quem recebi apoio e amizade durante todos esses anos.

O agradecimento especial é para meus pais e para minha irmã Letícia, cujo apoio emocional durante a realização deste trabalho foi incondicional, principalmente para a minha mãe, que me deu todo o suporte que lhe foi possível em todas as etapas de minha pesquisa.

Outro agradecimento especial para Márcio, companheiro querido, pelo carinho e paciência durante todos esses anos. 


\section{SUMÁRIO}

\section{Introdução}

\section{Primeiro Capítulo}

Redes e Peregrinações, a Circulação nas Manifestações Marianas. .......28

1) A circulação de Pessoas: Peregrinação.............................................35

a) A Aparição de Nossa Senhora em Jacareí....................................36

b) O Público das Aparições...........................................................40

c) A Prática Ritual dos Peregrinos..............................................42

d) Os Rituais Carismáticos Paroquiais e as Aparições Marianas....45

e) A Peregrinação: entre o “novo” e o “antigo”................................51

2) A Circulação das Manifestações Marianas: Redes..............................56

a) $\quad$ A Circulação das Manifestações Marianas..........................................57

b) As Conexões entre as Manifestações Marianas................................62

3)Redes: Territorialização x Desterritorialização....................................73

4) Igreja e Movimentos: a importância da intermediação

na religiosidade contemporânea...........................................................77

\section{Segundo capítulo}

A presença da Igreja nas aparições contemporâneas.............................89

1) A Igreja e as aparições do século XIX.................................................92

2) A Avaliação estabelecida pelo Vaticano................................................96

3) Rene Laurentin e a defesa das aparições de Nossa Senhora....................101

3.1) Laurentin e a defesa das aparições de Nossa Senhora.........................105

3.2) Laurentin e interlocutores: o lugar do “extraordinário” na Igreja.........109 
4) João Paulo II e as Aparições Marianas................................................115

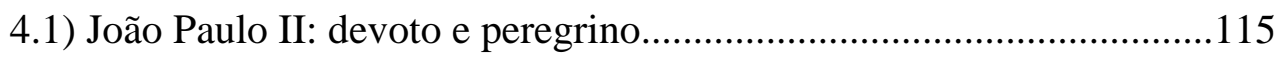

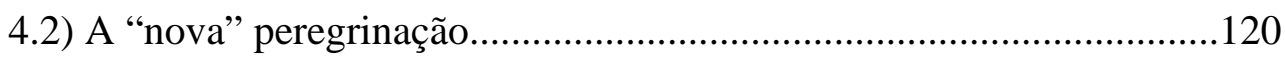

5) A organização hierárquica e burocrática da RCC:

Disseminação de Idéias e práticas..............................................................123

\section{Terceiro Capítulo}

As aparições de Nossa Senhora em Jacareí:

Continuidade e Modelagem................................................................................128

1)Continuidade Simbólica e Modelagem nas Aparições ............................134

1.1) Santuários e Peregrinações na Idade Média........................................135

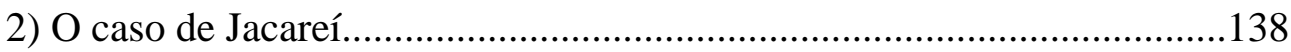

3) As aparições de Jacareí: a produção da legitimidade.............................141

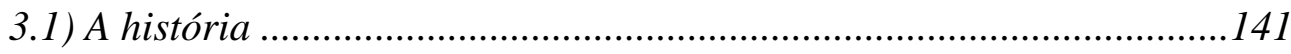

A) Quem é esta Jovem?

\section{2) O Santuário}

A) As aparições em local ermo............................................................142

B) O ponto da aparição......................................................................144

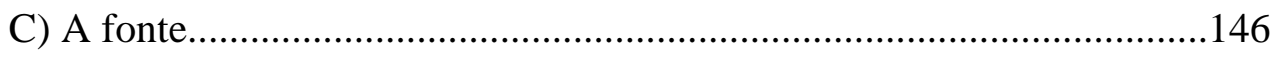

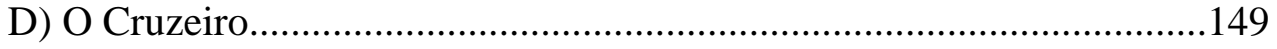

3.3) O Vidente

A) A Humildade e a Inocência ...............................................................152

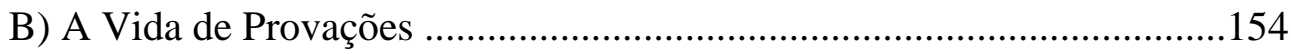

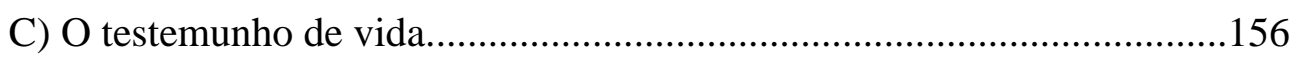


4) A Retração das Aparições ................................................................157

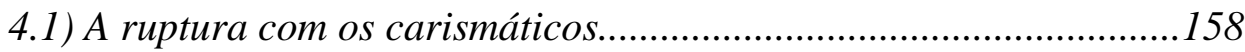

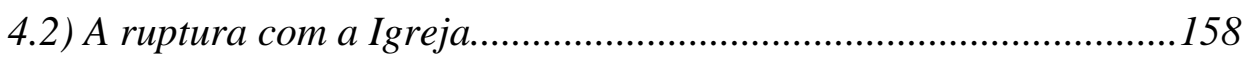

4.3) Os "exageros" do vidente e o combate do clero...............................159

4.4) O Vidente e a Comunidade: da inconsistência ao isolamento........162

5) As aparições contemporâneas: continuidades e inovações .................165

5.1) As mensagens e segredos.............................................................167

5.2) O Rosário e Nossa Senhora..............................................................170

\section{Quarto Capítulo:}

Maria nas aparições: elementos simbólicos e mensagens

1) Os dogmas marianos.

2) Maria: quem é esta mulher..................................................................182

2.1) A Fragilidade da Imagem..............................................................182

2.2) A Mensagem e suas interpretações....................................................183

A) Maria: Mãe …………………………………………………...187

B) Nossa Senhora: a Mediadora..........................................................191

C) Maria: Mater Dolorosa e Mulher de Coragem...................................195

D) Maria: a guerreira.........................................................................197

3) Nossa Senhora e o Fim dos Tempos...................................................201

3.1) Os elementos escatológicos das aparições.........................................203

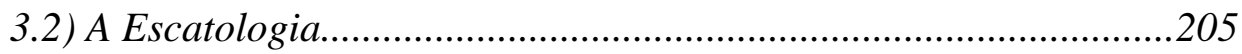

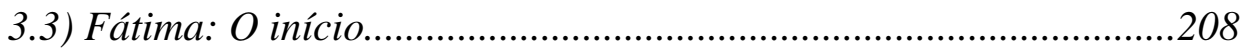

3.4) Garabandal: a continuação ...........................................................212

3.5) O Final: Por que Maria aparece em Jacareí? ………………….....215

Consideraçø̃es finais.......................................................................................221 


\section{Introdução}

As aparições da Virgem Maria tem se repetido em vários pontos do país, atraindo uma quantidade considerável de fiéis. Dados da revista Época afirmam existirem mais de trezentos casos de visões relatados no Brasil recentemente. Em pesquisas pela internet, constatamos a existência de várias páginas dedicadas a essas manifestações. Inclusive, não apenas as aparições marianas, mas outras manifestações extraordinárias relacionadas à Maria atraem, em alguns casos, multidões de pessoas. Exemplo disso foi o caso da chamada "Virgem da Vidraça”, na qual uma suposta imagem da Virgem foi estampada em uma vidraça, atraindo, durante semanas, um grande público ao local.

Embora a devoção a Nossa Senhora, em suas diversas denominações e invocações, seja característica marcante da religião católica, especialistas que analisaram as aparições na atualidade destacam que esses fenômenos têm aumentado nas últimas duas décadas (Mariz, 2000; Steil, 1995), sendo que Zindards-Swartz (1991), ao analisar as aparições de Nossa Senhora em Medjugorje, na antiga Iugoslávia, afirma a existência de um surto de aparições marianas nos últimos anos.

Nosso interesse pelas aparições marianas iniciou-se durante nossa pesquisa de mestrado, realizada entre os fiéis do movimento Renovação Carismática Católica (RCC). Percebemos não apenas a devoção e a centralidade da figura de Nossa Senhora durante os rituais do movimento, como também o interesse e a participação dos carismáticos nos eventos em que acreditam ocorrer manifestações visuais de Maria - as aparições.

Vale a pena destacar que esse surto de aparições, a partir da década de oitenta, é simultâneo ao momento em que RCC se expande e ganha força, não apenas no Brasil, mas em todo o mundo. Assim, embora os autores mencionados já tivessem destacado a proximidade entre o movimento carismático e as aparições marianas na atualidade, não fizeram dessa relação o foco da compreensão do fenômeno. Neste trabalho demonstraremos o papel do movimento carismático na expansão e na imputação de credibilidade às aparições de Maria.

Assim, alguns resultados obtidos em nossa pesquisa de mestrado foram importantes para esse desenho do problema referente às aparições de Nossa Senhora no 
Brasil. Embora as aparições marianas não fossem objetos do estudo daquele trabalho, a referência a elas aparecia constantemente nos rituais carismáticos, apesar delas não serem classificadas como pertencentes ao movimento. Por outro lado, nos rituais de aparições que assistimos para essa pesquisa a presença dos carismáticos era patente. Assim, não é possível compreender a configuração e o alcance desse fenômeno sem levar em conta a importância da presença dos carismáticos nesses eventos.

Dessa maneira, dois aspectos fundamentais do movimento carismático devem ser levados em conta para a melhor compreensão das aparições marianas: a constituição leiga e burocrática da organização institucional da RCC e a centralidade da devoção a Nossa Senhora em seus rituais. Pretendemos demonstrar neste trabalho que estas características foram fundamentais para que o caso da aparição de Jacareí se constituísse enquanto tal, mas isso não é tudo. Apesar da RCC desempenhar um papel central nesse surto de aparições contemporâneas no Brasil, existem outros fatores não relacionados a ela que não podem ser ignorados, pois também contribuem para o sucesso destas manifestações. De nosso ponto de vista é importante incorporar à análise sua dimensão simbólica. Trata-se de compreender os processos que tornam uma manifestação em que uma ou mais pessoas afirmam ter visto e/ou ouvido Nossa Senhora numa aparição, ou seja, em um fenômeno que mobiliza multidões, que por curiosidade ou crença, participam de rituais nos quais, segundo eles, Maria aparece e se comunica com um vidente.

Nesse sentido, entre o momento em que uma pessoa afirma ter visto e ouvido Nossa Senhora e o momento no qual o local ou fenômeno se torna uma "aparição” há um longo processo, que envolve diferentes atores - pessoas, grupos e instituições - e que mobiliza vários elementos simbólicos. Nossa intenção nesta tese é mapear os agentes e os elementos simbólicos que são capazes de transformar um ato esparso e localizado em um fenômeno social complexo. Essa questão é tão ou mais importante devido ao fato de que não são todas as manifestações marianas que obtém sucesso, pelo contrário, a grande maioria delas não chega a constituir-se em um ritual ou a atrair participação de fiéis; outras atraem pessoas durante um período muito curto de tempo, como ocorreu no caso mencionado da Virgem da Vidraça. Dessa forma, buscamos compreender neste trabalho o processo social e simbólico que sustenta a formação de convicções coletivas em torno das aparições que sempre tem seu início em testemunhos pessoais sobre visões de Nossa Senhora. Essa “convicção coletiva” é medida pela 
capacidade de mobilização de participantes nos rituais em que ocorre a manifestação de Maria.

Fatores de diferente ordem se mostraram centrais neste processo social e simbólico de “construção” das aparições marianas. Entre eles destacamos: as relações e conexões estabelecidas entre os atores e grupos envolvidos - inserindo a aparição numa “rede” de manifestações marianas -; o papel desempenhado pela Igreja Católica - na produção de idéias e crenças que servem como fonte de legitimidade para as aparições -; a modelagem simbólica das aparições e a presença de elementos simbólicos de longa duração. Podemos dizer que a aparição vai sendo “construída”, a partir das relações estabelecidas e dos elementos simbólicos acionados. Porém, não é só isso, pois, para que essa "construção" obtenha sucesso é preciso que ela faça sentido para quem dela participa e atenda as expectativas dos indivíduos na contemporaneidade.

\section{1) A rede de aparições marianas}

No primeiro capítulo buscamos descrever e compreender as relações entre os fenômenos. Importa destacar que apesar de partirmos de um caso específico - as aparições de Nossa Senhora ocorridas na cidade de Jacareí, interior de São Paulo - esses fenômenos não estão isolados, ou seja, há uma rede de manifestações extraordinárias de Nossa Senhora no Brasil atualmente, que se conecta entre si, permitindo a circulação de idéias, informações, pessoas e dos próprios eventos, e que se estende e busca legitimidade nos fenômenos europeus reconhecidos - especialmente Lourdes, Fátima e Medjugorje ${ }^{1}$.

Ao analisarmos as peregrinações às aparições marianas constatamos que uma análise centrada nos grupos vinculados a uma manifestação não seria suficiente para a compreensão da complexidade adquirida por esses fenômenos na atualidade. Apesar de existirem grupos que são vinculados e acompanham de perto uma manifestação, o sucesso delas depende das relações e contatos estabelecidos pelos participantes dos fenômenos, que ultrapassavam os limites da aparição e de seu Santuário. A utilização do conceito de redes nos permitiu entender as relações estabelecidas entre os membros das manifestações marianas. Segundo a definição de Barnes (1969) que usamos como referência em nossa análise, rede é “um conjunto de relações interpessoais que vinculam indivíduos a outros indivíduos” (1969:167), que

\footnotetext{
${ }^{1}$ Embora esta aparição não seja reconhecida oficialmente, é um dos maiores santuários marianos da atualidade e importante fonte de inspiração para as aparições no Brasil.
} 
permite ampliar o foco de nossa análise, incluindo "processos sociais que envolvem conexões que transpassam os limites de grupos e categorias” (1969:163).

Assim, apesar de partimos de um evento - a aparição de Nossa Senhora em Jacareí - nosso interesse não está exclusivamente em uma manifestação, mas nas relações sociais e simbólicas entre elas. A concepção de rede, por enfatizar as conexões entre grupos e indivíduos, nos permitiu sistematizar a análise das relações entre os participantes desses eventos, e perceber seu papel chave na sua organização e divulgação.

Dessa forma, nosso primeiro esforço foi o mapeamento da rede de conexões entre as manifestações e das práticas rituais dos participantes das aparições marianas na contemporaneidade, pois a inserção nesta rede constituía parte fundamental do sucesso das manifestações.

Além disso, o mapeamento da rede, realizado no primeiro capítulo, nos trouxe dados sobre os elementos em circulação e dos atores e grupos em destaque na rede - os "nós” da rede, que foram analisados nos capítulos seguintes. Observamos os atores e grupos que assumiam papéis centrais neste processo e, consequentemente, nas aparições marianas. Dois atores se destacaram: a Igreja Católica como um todo e o movimento Renovação Carismática Católica em particular.

\section{2) O papel da Igreja}

A Igreja Católica é parte importante do processo que dá sustentação e legitimidade para as aparições marianas na atualidade, sendo sua centralidade observada principalmente em dois aspectos: na produção de idéias para a legitimação das manifestações e na atribuição de novos sentidos para antigos símbolos do catolicismo, como a peregrinação.

Assim, no segundo capítulo demonstramos a centralidade da Igreja Católica na construção da legitimidade das aparições marianas contemporâneas. Importantes membros da hierarquia católica estão envolvidos nestes fenômenos, produzindo idéias, crenças e práticas que servem como fontes de valor para elas. Entre eles destacamos o teólogo René Laurentin e o Papa João Paulo II.

René Laurentin é um importante teólogo mariano e incansável defensor das aparições de Nossa Senhora no catolicismo, escrevendo vários livros repletos de documentos e análises. Já João Paulo II é o exemplo da fé e devoção, ele representa o novo peregrino. 
A análise desenvolvida por Phillipe Portier (2003) sobre o pensamento de João Paulo II traz uma reflexão sobre o papel da instituição católica na ressignificação de elementos de longa duração que trouxe importantes pistas para nosso problema de pesquisa. Especificamente a concepção de “ajustamento”, que corresponde à idéia de que não há uma adequação da Igreja à modernidade, mas sim um ajustamento, em que os elementos presentes anteriormente em um contexto de religião "tradicional” não desaparecem e nem são deixados de lado, pelo contrário, permanecem como eixo central das políticas e práticas adotadas, embora utilizando elementos e expressões que pertencem a esse novo contexto, chamado pelo autor de modernidade. Em seu modelo de ajustamento defende que novos termos e temas se inserem no discurso papal, porém, sem que as concepções “antigas e conservadoras” presentes no Vaticano fossem totalmente subvertidas.

O estudo desenvolvido por Portier argumenta que a Instituição Católica se mantém na atualidade, e que não precisa desenvolver “estratégias” para “sobreviver” ou para se "adequar" a esse novo contexto, mas, ao contrário, possui poder e influência, sendo capaz de manter seus conteúdos e dogmas centrais, mas de uma forma mais “aceitável” no mundo contemporâneo. Na verdade, a incorporação do novo permite a continuidade do pensamento teológico, nos termos já bem sedimentados de sua tradição dogmática, ressignificando as práticas contemporâneas, incorporando-as a seu sistema de pensamento.

Dessa forma, a Igreja não está à parte na religiosidade contemporânea. As idéias produzidas e as práticas desempenhadas por seus representantes atribuem valor às aparições e sentido para os símbolos associados a ela. Podemos adiantar que as peregrinações realizadas por João Paulo II são emblemáticas nesse sentido, pois ele dá início a uma nova forma de peregrinar que possui características semelhantes à movimentação de pessoas e de manifestações pela rede de aparições marianas. Ou seja, as novas características e sentidos da peregrinação na religiosidade contemporânea são em parte instituídos pelo supremo representante da Igreja: o Papa.

\section{3) A peregrinação}

A peregrinação é um elemento central que perpassa os dois primeiros capítulos, sendo sua análise parte importante de nosso trabalho. A participação nas aparições de Nossa Senhora ocorre pelo deslocamento de pessoas para os rituais de aparições. 
Embora a peregrinação seja um tema clássico na antropologia, seus estudos foram realizados em comunidades rurais, ou em grupos originários de pequenas cidades, nos quais as práticas rituais da religiosidade popular eram preponderantes. Neste contexto do catolicismo popular a principal razão da realização da romaria é a promessa realizada pelo devoto ao santo, sendo que a peregrinação é a forma de pagamento de um voto ou milagre alcançado. Assim, é estabelecida uma relação de aliança entre o peregrino e o santo, de reciprocidade, em que o peregrino recebe a graça e realiza a peregrinação como pagamento.

De acordo com estudiosos do tema, a promessa e seu pagamento expressam no plano simbólico as relações sociais presentes nas comunidades, em pequenas localidades - o estudo desenvolvido por Zaluar (1983) analisa as conexões entre as práticas rituais e as relações sociais em comunidades de pequena escala. Assim, trabalha com elementos simbólicos duradouros, mas cujo significado deve também ser buscado nas relações entre indivíduos e grupos sociais presentes no contexto analisado.

Procuramos destacar em nosso trabalho que os dois elementos que constituem o cerne dos estudos sobre as romarias para os santuários do catolicismo popular perdem a centralidade. Por um lado, o contexto em que elas ocorrem não são mais as pequenas comunidades, mas as cidades de médio e grande porte, marcadas por relações sociais de outro tipo. Por outro lado, a promessa perde a importância.

Ao analisarmos a peregrinação nas sociedades contemporâneas não podemos deixar de nos remeter aos estudos realizados por Daniélle Hervieu-Léger (1999) sobre a "modernidade religiosa” - as características e o lugar ocupado pela religião na sociedade contemporânea. Para essa autora a modernidade religiosa está fundamentada em duas bases: a autonomia do indivíduo e a perda de poder da instituição religiosa.

O peregrino é a figura típica da "modernidade religiosa”, representando o indivíduo autônomo e livre para realizar suas escolhas, inclusive religiosas. Assim, a individualização que marca as sociedades contemporâneas é também observada na modernidade religiosa, por meio da figura do peregrino.

Associada à autonomia do individuo está a perda do poder da instituição religiosa. Segundo Hervieu-Léger, antes a participação religiosa era herdada pelos indivíduos, estando relacionada à tradição. $\mathrm{Na}$ atualidade os indivíduos realizam suas escolhas e não aceitam os parâmetros religiosos e culturais socialmente herdados, sendo que as instituições ligadas à tradição - como o catolicismo -, perdem a importância diante da centralidade atribuída à escolha do indivíduo. Ou seja, os indivíduos não 
herdam a sua religiosidade, mas escolhem sua forma de agir religiosa e, neste processo não seguem os dogmas estabelecidos pela Instituição.

Há uma ruptura entre crer e pertencer, o peregrino crê, mas não pertence a uma religião - pois não segue os seus dogmas. Pertencer, no entender de toda uma sociologia da religião, é seguir aos dogmas e receber os sacramentos, que fazia do crente um praticante, figura importante no aferimento da vitalidade de uma denominação religiosa. Nesse sentido, para a autora, a Instituição perde importância no agir religioso contemporâneo, pois seus dogmas não são mais seguidos pelos fiéis, embora eles continuem a crer em seus símbolos. Dessa maneira, na sociedade contemporânea a Instituição perde seu lugar para o indivíduo, autônomo e livre, que busca realizar suas escolhas.

No Brasil, sob inspiração da análise weberiana do protestantismo, vários estudos já haviam apontado para a crescente autonomia do indivíduo e a diminuição da dimensão institucional da religião. Lembramos o trabalho de Prandi e Pierucci sobre o conceito de internalização desenvolvido por Procópio Camargo, considerando-o como a própria racionalização do agir religioso; "é o assumir conscientemente um determinado comportamento religioso e, no mesmo movimento, distinguir-se em oposição à religião tradicional” (1996:12). A internalização é conquistada contra o tradicionalismo e contra os valores dados, sendo que, para esses autores, a ocorrência e a expansão das religiões internalizadas representam um acréscimo de racionalidade na cultura. Notamos, pois, que a internalização está inextricavelmente relacionada com a mudança - ou mesmo ruptura no comportamento religioso. Mudança esta que leva a sociedade brasileira rumo à modernidade - percebida como positiva pelos autores - como na seguinte passagem: “mesmo as religiões mais densas de sacralidade podem ser portadoras de racionalidade, e por conseguintes sintomas da modernização da sociedade onde surgem e se esparramam, desde que se dêem como formas conscientes $e$ voluntárias de adesão a um corpo de símbolos religiosos.” (1996:13). Assim, para esses autores, a racionalidade e a modernização - no sentido weberiano - são os caminhos tomados pelas religiões no Brasil. E esse caminho parece ser positivo para eles, como o era para Candido Procópio, quando afirmam que para esse autor quanto mais internalizada a religião melhor, pois consciente e voluntariamente aceita. No prefácio redigido por eles ao livro "A realidade social das religiões no Brasil" permanece a impressão de que o caminho da modernidade e da internalização das religiões é o melhor caminho para as religiões no Brasil. Perpassa nesta obra pelas 
concepções de religião como um corpo doutrinário e de conversão - ou reconversão como a adesão consciente à doutrina, valores e comportamentos religiosos.

Também Procópio Ferreira considerava que o processo de internalização de uma religião como positivo no âmbito da modernização da sociedade. Entretanto, não podemos nos referir a esse processo de racionalização da religião - ou das religiões, sem mencionarmos outra dimensão da teoria weberiana que o acompanha - 0 desencantamento do mundo. Não é nossa intenção nesta introdução realizar uma retomada de toda essa complexa e importante teoria, mas apenas destacar que o desencantamento é o processo religioso pelo qual as religiões operam a eliminação da magia como meio de salvação.

A concepção do desencantamento do mundo é diferente da concepção da secularização, para Weber, embora ambas façam parte do processo de modernização. Essa diferenciação fica muito clara no texto de Pierucci (2000), em que o autor coloca:

“São as religiões éticas que operam a eliminação da magia como meio de salvação, como fica explicitado nesta outra passagem da ética protestante, em que Weber estabelece a seguinte equação: o desencantamento do mundo: a eliminação da magia como meio de salvação. (...) Secularização, por outro lado, implica abandono, redução subtração do status religioso; é a perda para a religião e a emancipação em relação a ela.”

Nesse sentido, o autor destaca que desencantamento e secularização são dois processos diferentes, enquanto o desencantamento do mundo remete a luta da religião contra a magia, em que esta perde a sua centralidade; a secularização remete-se a luta da modernidade cultural contra a religião, a separação da sociedade em esferas - sendo a esfera religiosa separada da esfera política. A soma desses dois processos no processo de modernização, segundo Pierucci, traz efeitos negativos para a religião, pois faz avançar o desencantamento do mundo concomitante a uma crescente racionalização da dominação política, que é laicizadora. Assim, apesar de Pierucci diferenciar os dois processos mencionados, ele reconhece que ambos compõem o processo de modernização, e que isso leva ao declínio da religião, pois, por um lado ela perde influência na esfera pública - o Estado é laico - e, por outro lado, as religiões perdem sua dimensão mágica com o avanço da racionalização. 
Para Pierucci (1997) a secularização, nos termos adotados por Weber, já aconteceu, trata-se de um processo irreversível, a criação e a emancipação das esferas já ocorreu. O autor vai além, afirmando que se trata mesmo de declínio da religião, pois, com a separação em esferas, desde o século XVIII a religião perdeu o lugar que ocupava nas sociedades tradicionais e essa perda de lugar vem aumentando desde então, nas palavras de Pierucci: “após a perda de espaço e poder no aparelho do Estado laicizado, (...) perda de influência no espaço público perda de força e autoridade sobre a vida cotidiana” (104:1997). A religião está restrita, na atualidade, ao âmbito da vida privada das pessoas, não exercendo qualquer influência pública.

É a partir desta perspectiva que o autor defende a idéia de que o aumento e a centralidade dos chamados Novos Movimentos Religiosos - NMRs - no Brasil expressam o processo de secularização e de desencantamento, significando a perda estrutural da posição hegemônica da religião.

Além disso, o autor vislumbra um declínio geral do compromisso religioso nos NMRs, comparando-os a supermercados espirituais: "O consumidor religioso escolhe uma e até mais de uma experiência mística, ou solução espiritual, ou serviço religioso dentre uma grande variedade de propostas provocantemente expostas no supermercado espiritual” (112:1997). Nesse sentido, percebemos que o autor, ao conceber a religião como um conjunto coeso de crenças e comportamentos, que são interiorizados pelos fiéis, ao qual eles aderem de forma racional, não considera os NMRs como religião. Seu crescimento na sociedade brasileira está relacionado ao processo de declínio da religião; pela diminuição da presença e influência da religião e pela diminuição do compromisso religioso dos indivíduos.

O estudo destes dois autores sobre a sociedade brasileira e o de HervieuLéger (1999) sobre a sociedade francesa podem ser aproximados, especialmente em três aspectos: a ênfase na perda do poder da religião institucional no mundo contemporâneo; a concepção do pertencimento religioso como adesão ao conjunto doutrinário de uma religião; e autonomia do indivíduo diante de uma série de ofertas religiosas. No entanto, importa reiterar que Hervieu-Léger não considera que a religião esteja em declínio - ela sequer usa este conceito. Ela menciona que a Instituição, especialmente as tradicionais, perdem seu espaço para os indivíduos, que não são mais “praticantes”, ou seja, adeptos do conjunto de normas estatuídas pelas instituições. 
Dessa maneira, seu estudo leva em conta o agir religioso na atualidade, que ele não é mais caracterizado pela adesão a uma religião - no sentido clássico dos dois termos -, mas pela mobilidade entre experiências religiosas - realizada pelo peregrino.

O peregrino é, pois, uma figura movente. Ele não é adepto de um conjunto de crenças e práticas, mas circula em busca de experiências religiosas. Esta concepção da autora foi importante para nosso trabalho, pois não considera o agir religioso como fixo, como adesão a práticas e normas. A fluidez foi central para a nossa compreensão da peregrinação e dos peregrinos e também dos fenômenos de aparição, de forma mais geral.

No entanto, duas outras dimensões correlacionadas na análise de HervieuLéger sobre o agir religioso contemporâneo são questionadas em nosso trabalho: a perda do espaço da Instituição religiosa, considerada como a perda da influência sobre os indivíduos e a grande autonomia do indivíduo em suas opções religiosas.

Demonstraremos que, mesmo a adesão religiosa não sendo observada entre os peregrinos das aparições marianas, as idéias e crenças produzidas pela Igreja influenciam e fundamentam seu agir religioso, sendo a realização da peregrinação o exemplo chave. Observamos que a Igreja Católica é importante para a constituição da legitimidade destes fenômenos, especialmente por meio de seus sacerdotes e movimentos.

Além disso, nas aparições de Nossa Senhora os participantes estão inseridos em importantes redes de relações religiosas, sendo a partir delas que tomam conhecimento sobre esse tipo de fenômeno - adquiriam informações e se interessavam por eles - e circulam entre eles. Essas relações eram estabelecidas principalmente nos rituais de base da RCC, sendo que parte significativa dos participantes era constituída de carismáticos, mas não só, pois esses contatos se estendiam aos grupos paroquiais e de vizinhança, também fornecedores de peregrinos para as aparições.

\section{4) As aparições: modelagem e continuidade}

O terceiro e o quarto capítulos são dedicados à análise dos elementos simbólicos das aparições de Nossa Senhora. Trabalhamos a hipótese de a dimensão simbólica ser central na construção dos fenômenos, sendo que parte importante da constituição de sua legitimidade se deve a presença e ao acionamento de uma 
simbologia de longa duração no catolicismo e a modelagem das manifestações a um padrão de aparições estabelecido a partir do século XIX.

O conceito de modelagem aqui utilizado vem do estudo realizado por Elisabeth Claverie (2003) sobre as aparições de Nossa Senhora na vila de Medjugorje, na Bósnia. Segundo ela, esta aparição foi modelada pelos atores envolvidos no fenômeno, principalmente os franciscanos da localidade. Para eles as aparições deveriam estar de acordo com determinados padrões recorrentes neste tipo de evento, realizando, então, um trabalho de "modelagem” da Virgem de Medjugorje, de forma a torná-la mais aceitável por meio da sua aproximação com as manifestações conhecidas e, de preferência, reconhecidas. Assim, realiza-se a adequação da Virgem de Medjugorje a um padrão de aparições estabelecido.

Nas aparições de Jacareí constatamos que na primeira década do evento a sua modelagem é realizada principalmente pelos carismáticos, que se apropriam das manifestações. Dois aspectos merecem ser destacados com relação a este tema: por um lado o estabelecimento de um padrão de aparições no final do século XIX e início do século XX, ao qual a aparição de Jacareí vai sendo modelada - a modelagem é percebida em três aspectos principais: na construção do Santuário, nas características do vidente e na história sobre os fenômenos, sendo que cada uma delas procura se aproximar deste padrão. Por outro lado, para que a modelagem possa ser realizada é preciso conhecimento sobre o padrão estabelecido - ou seja, os atores envolvidos na modelagem devem possuir conhecimento sobre as aparições reconhecidas - adquirido por meio das informações sobre elas e da circulação - peregrinação - entre fenômenos do mesmo tipo, especialmente os Santuários marianos reconhecidos - Fátima, Lourdes e Medjugorje.

O conceito de modelagem mostrou-se um instrumento importante na compreensão do processo social e simbólico responsável pela construção e sustentação das aparições marianas, sendo detalhada no terceiro capítulo, no qual demonstraremos que o prestígio inicial das aparições de Nossa Senhora na cidade de Jacareí e o declínio posterior da sua legitimidade dependeram de sua aproximação relativa ao padrão. Dessa forma, constatamos que a aproximação ao modelo foi central para o sucesso da aparição de Jacareí, em um primeiro momento, e que o distanciamento deste padrão contribuiu para o seu declínio. 


\section{5) A simbologia de longa duração}

A constatação da existência de um padrão de aparições constituído no século XIX, a partir do qual as aparições marianas contemporâneas se inspiram e são modeladas, porém, não é suficiente para a compreensão do sistema simbólico destes fenômenos. Há elementos importantes, especialmente no que se refere à simbologia mariana e a escatologia, e que possuem origem bastante anterior ao período de formação de um modelo para estes fenômenos: o século XIX. Assim, as características de Maria nas aparições possuem profundidade histórica, remetendo-se a crenças e práticas que ultrapassam o padrão mencionado. Sob esse aspecto, a análise da simbologia da Virgem nas aparições contemporâneas, demonstrando sua longa duração no imaginário católico e os sentidos atribuídos na atualidade também foi parte importante de nosso trabalho, sendo analisado no quarto capítulo desta tese.

Assim, apesar do século XIX ser considerado inaugural para as aparições por alguns autores, importantes elementos simbólicos que as constituem não são novidades estabelecidas por elas. Isso se deve, em parte, ao fato desse modelo, especialmente na França, ter sido construído por uma rede de clérigos interessados nos fenômenos franceses. Ou seja, a proximidade entre as aparições ocorridas neste período foi estabelecida por representantes da Igreja, que criam um “modelo". Além disso, estudos sobre as aparições marianas deste período (Harris, 2001) demonstram que elas apenas obtêm legitimidade devido ao reconhecimento dos elementos simbólicos por parte da população local. Ou seja, aparições não representam uma novidade no sistema simbólico dos locais.

Dessa forma, a concepção de que as aparições do século XIX inauguram um novo tipo de evento, com características específicas, torna-se mais complexa. Há um fenômeno específico sendo constituído neste momento a partir das aparições marianas francesas do século XIX - Lourdes, La Salette e Pontmain - porém, elementos importantes destas manifestações já estavam presentes anteriormente. Segundo Barnay (2000) em seu estudo sobre as aparições de Nossa Senhora na Idade Média, a crença no contato entre a Virgem Maria e os homens está presente no cristianismo no ocidente desde o século $\mathrm{X}$.

Nesse sentido, a existência de elementos de continuidade e o seu reconhecimento pela população são centrais para a aceitação das aparições do século XIX, como bem demonstrado por Harris (2001) em seu estudo sobre a aparição de 
Lourdes, e também das manifestações posteriores, como o caso de Medjugorje estudado por Claverie (2003).

Devemos destacar que elementos simbólicos centrais às manifestações apontam para a continuidade entre as aparições medievais, as aparições do século XIX e as aparições contemporâneas, sendo observados nas manifestações da atualidade, como em Jacareí. Assim, a longa duração da simbologia de Nossa Senhora constitui parte importante destes fenômenos.

Notamos que a simbologia mariana acionada nas aparições possui profundidade histórica, sendo símbolos associados a Nossa Senhora desde muito tempo no cristianismo. A esses símbolos, porém, são atribuídos significados que demonstram valores e características importantes da sociedade contemporânea. Assim, estes símbolos são, por um lado reconhecidos pelos peregrinos, estando presentes no imaginário de longa duração do cristianismo, mas através deles também percebemos características e valores importantes das sociedades contemporâneas, fazendo então sentido no contexto e no modo de vida dos indivíduos na atualidade. 


\section{Aspectos metodológicos}

Esta tese é o resultado de pesquisa desenvolvida sobre as aparições de Nossa Senhora que levou em consideração e buscou combinar diferentes recursos metodológicos. Iniciamos nosso trabalho pela participação nos rituais de aparição cenáculos - realizados na cidade de Jacareí. Escolhemos este ritual devido ao contato com os fiéis do movimento carismático no Vale do Paraíba - estudados em nossa dissertação de mestrado - e que participavam desta manifestação. Inclusive, nosso interesse por estes fenômenos teve início durante a pesquisa de mestrado sobre a Renovação Carismática, em que parte dos adeptos do movimento mantinha contato com manifestações deste tipo - posteriormente, ao longo desta análise, observamos a importância central dos carismáticos para o sucesso das aparições.

Nesta primeira etapa, procuramos levantar os diferentes grupos de freqüentadores das aparições, pois, logo em nossas primeiras visitas a campo notamos que não existia apenas um grupo homogêneo de participantes. Assim, nosso primeiro esforço foi compreender quem eram os freqüentadores e as relações religiosas estabelecidas por eles. Para isso nos valemos da observação dos rituais, de conversas com representantes de diferentes grupos de freqüentadores e de entrevistas. Os dados empíricos foram obtidos a partir da observação em rituais de aparição e outros tipos de manifestações de Maria aos homens, desde Julho de 2003. Podemos citar alguns destes rituais:

Cenáculos de Aparição de Nossa Senhora em Jacareí, São Paulo: Julho, Agosto, Outubro de 2003; Julho e Dezembro de 2004; Janeiro, Fevereiro de 2005; Dezembro de 2007; Fevereiro, Março e Abril de 2008.

Visitas da Imagem Itinerante de Nossa Senhora, que verte mel, à São José dos Campos: Julho de 2004.

Palestra e locução realizadas por Raimundo Lopes mensageiro de Nossa Senhora - em São José dos Campos.

- $\quad$ Palestra e locução realizadas por Vassula Ryden - mensageira de Nossa Senhora - em São Paulo.

Cenáculos Marianos de Pe Gobbi realizados em São José dos Campos, entre Julho de 2004 e Fevereiro de 2005. 
No que se refere à observação de rituais, também utilizamos gravações em fitas cassete, realizadas pelos próprios informantes ou compradas nos Cenáculos da Aparição de Jacareí. Desta maneira, pudemos também analisar os rituais realizados em Muriaé, Minas Gerais - vidente Mirna -, Niterói, Rio de Janeiro - vidente Ricardo - e Piedade das Gerais - vidente Marilda.

Ainda nesse primeiro momento de pesquisa de campo, levamos em conta os materiais impressos e virtuais divulgados pelos diferentes grupos participantes, atentando para as mensagens e para as interpretações dadas a elas. Assim, a consulta a sites católicos e carismáticos que divulgam as aparições marianas também foi constante durante nosso trabalho, bem como a análise de vários tipos de materiais publicados pelos grupos que acompanham as aparições e pelos fiéis do movimento Renovação Carismática Católica (RCC), como jornais, revistas, livros e CDs.

Já em uma segunda etapa do trabalho de campo, aprofundamos a análise do discurso de seus seguidores, por meio de entrevistas em profundidade com fiéis de cada grupo de participantes - vidente, carismáticos, representantes da Igreja e peregrinos - e da análise de suas falas durante os rituais. As entrevistas em profundidade foram realizadas enfocando a experiência religiosa dos seguidores, buscando captar suas redes de relações religiosas, no intuito de realizar uma classificação dos freqüentadores de aparições.

Dessa forma, a análise das mensagens e do material publicado foi combinada com as entrevistas e as observações diretas do comportamento dos seguidores e videntes, para, na etapa final da pesquisa, sistematizar o material empírico obtido e interpretá-lo a luz da bibliografia utilizada ao longo do trabalho.

Assim, por meio da combinação destas diferentes formas de observação pudemos perceber a conexão e a continuidade entre as aparições de Nossa Senhora. Os dados sobre ela estavam presentes nos sites católicos, nos materiais sobre as manifestações - livros, folhetos, cds, dvds, entre outros - bem como podia ser percebida na fala dos videntes durante os rituais - que sempre se referiam aos fenômenos diversos e citavam mensagens de Maria transmitidas em localidades distintas -, e no comportamento dos participantes - que sempre buscavam se informar sobre outras manifestações, conversando com outros participantes e/ou comprando produtos sobre diversos fenômenos. Restava-nos, pois, desvendar essa rede que colocava em contato as 
aparições marianas e seus participantes - que optamos chamar de peregrinos devido à mobilidade entre fenômenos do mesmo tipo.

Nesta etapa do trabalho as conversas com os peregrinos durante os rituais foi muito importante, sendo através delas que começamos a mapear a intrincada rede de manifestações, buscando compreender os contatos entre os participantes e entre as próprias manifestações de Nossa Senhora - esta rede está descrita no primeiro capítulo. Além disso, as entrevistas realizadas com participantes dos Cenáculos - confidentes, videntes e peregrinos - também foram fundamentais para a compreensão das características desta rede de aparições marianas. Parte destas entrevistas foi realizada durante os rituais, sendo entrevistas mais curtas e rápidas, e outra parte foi marcada com antecedência, mais longas e com mais detalhes, totalizando vinte e três entrevistas.

Dessa maneira, a partir da observação, das conversas, entrevistas e da pesquisa de material produzido pelos envolvidos nos fenômenos, conseguimos perceber que as aparições marianas não se tratavam de fenômenos isolados, mas inseridos em uma rede pela qual circulavam pessoas, informações e as próprias manifestações.

Importa destacar que, após desvendarmos a configuração da rede, notamos a existência de importantes "nós”, ou “elos”, que assumiam papéis de destaque na produção da legitimidade das manifestações. Entre eles se destacavam a Igreja Católica, por meio de seus sacerdotes e teólogos, e o movimento carismático. A relação entre a RCC e as aparições marianas, embora tenha sido percebida desde nossa pesquisa de mestrado, somente foi sistematizada nesta tese, perpassando várias partes do trabalho.

Já a importância da Igreja Católica e seus representantes foi constatada devido à leitura de processos e de documentos teológicos sobre as aparições de Nossa Senhora. A leitura documental foi realizada durante meu estágio de doutorado sanduíche na École des Hautes Études em Sciences Sociales - EHESS - em Paris, França. Os documentos sobre as aparições, bem como os pareceres dos diferentes teólogos sobre elas foram obtidos na "Bibliotéque du Salchoir", pertencente ao monastério dos dominicanos de Paris.

Neste período realizei a leitura dos documentos sobre os processos das aparições de Lourdes, Fátima, La Salette e Pontmain, bem como os pareceres de diversos teólogos sobre cada uma delas e os debates estabelecidos entre eles. Embora essa documentação não tenha sido utilizada diretamente na escrita da tese, esta fase do 
trabalho foi importante para percepção da centralidade do papel desempenhado pelos sacerdotes e teólogos no processo de legitimação de uma manifestação. A leitura da documentação do processo de Fátima, por exemplo, em que o empenho de um sacerdote foi determinante para o seu reconhecimento, nos forneceu a pista importante sobre a centralidade da Igreja, por meio de seus representantes, na construção da legitimidade das aparições. Além disso, percebi a existência de um intenso debate sobre as aparições marianas, não apenas de forma geral - o Vaticano possui uma série de normas a serem seguidas para a análise dos fenômenos - mas também sobre cada manifestação específica, e que serve como fonte para a legitimação ou para a deslegitimação de um fenômeno por parte de seus participantes.

Ao constatarmos a importância da Igreja sobre as aparições de Nossa Senhora no passado, passamos a compreensão de sua presença e influência sobre as manifestações contemporâneas. Para isso realizamos a leitura de várias obras do teólogo mariano René Laurentin, importante defensor das aparições de Nossa Senhora desde meados do século XX, e algumas encíclicas do Papa João Paulo II - a referência a eles é constante no discurso dos carismáticos e videntes. O cruzamento das leituras teológicas e documentais com o material de campo nos possibilitou a percepção da semelhança entre eles, sendo as justificativas e o vocabulário presente nestes documentos era muito semelhante ao observado em nosso trabalho de campo nas aparições - no discurso dos participantes e no material sobre as manifestações. Ou seja, estes dois representantes da Igreja participavam da rede de aparições marianas; eles produziam idéias, crenças e práticas que circulavam e eram reproduzidas entre os peregrinos e entre as manifestações, servindo também como fonte para a sua legitimidade.

No entanto, os representantes da Igreja não são os únicos a se destacarem no processo de legitimação dos fenômenos marianos. A observação dos Cenáculos de Jacareí em dois momentos distintos: no início dos anos 2000 - especificamente em 2003 e 2004 - e posteriormente em 2008 foi fundamental para percebermos os atores, fatos e elementos envolvidos neste processo, pois neste intervalo de tempo ocorreram importantes mudanças que levaram ao declínio dos Cenáculos. No primeiro momento havia um grande número de freqüentadores - peregrinos de toda região sudeste participavam dos Cenáculos mensais. Já em 2008 a freqüência aos Cenáculos estava restrita a um pequeno grupo de participantes fixos, o número de peregrinos havia diminuído drasticamente. 
Diante deste fato, buscamos compreender os fatores que contribuíram para o sucesso desta manifestação no final dos anos noventa - tendo por base as observações realizadas durante o primeiro período de trabalho de campo e principalmente as entrevistas e depoimentos dos freqüentadores - e aqueles que levaram ao declínio deste fenômeno. Dessa maneira, realizamos o estudo de caso da aparição de Jacareí, observando o processo de “construção” e de declínio deste fenômeno.

Nesta etapa da pesquisa a concepção “modelagem” das aparições, elaborado por Elisabeth Claverie em seu estudo sobre a aparição de Medjugorje, foi fundamental para a compreensão desta manifestação. Segundo ela, há um padrão de aparições de Nossa Senhora elaborado no século XIX e ao qual a aparição mencionada é modelada. Nesse sentido, ao analisarmos o material de campo levantado, especialmente as mudanças ocorridas no ritual, na fala, no comportamento e nas relações estabelecidas pelo vidente, observamos que a aparição de Jacareí foi moldada simbolicamente ao longo do tempo de acordo com o padrão de manifestações, e que o afastamento do modelo a partir dos anos 2000 - realizado principalmente pelo vidente - levou ao descrédito deste fenômeno diante dos peregrinos, que deixaram de freqüentá-lo. Assim, avaliamos, pois, o caso de Jacareí sob o enfoque da bibliografia específica sobre as aparições, e constatamos que a sua aproximação ao padrão de manifestações reconhecidas foi parte importante de seu processo de legitimação.

Por fim, além da leitura dos documentos históricos, a bibliografia produzida por historiadores sobre as aparições de Nossa Senhora na Idade Média e Moderna também foi parte de nosso trabalho. Esta pesquisa foi desenvolvida durante o estágio de doutorado sanduíche, em que realizamos o levantamento da bibliografia sobre as aparições marianas na biblioteca da "Maison des Sciences de l'homme” e na biblioteca do “Centre des Études des faits religieux”, e nos deparamos com uma grande produção bibliográfica sobre este fenômeno pelos historiadores. Como a referência às aparições do final do século XIX era constante durante os Cenáculos, no discurso dos participantes e no material sobre os fenômenos, percebemos a necessidade de nos aprofundar nas aparições reconhecidas - que servem de inspiração e modelo para os fenômenos da atualidade.

Assim, apreendemos os elementos e as características do "modelo" de aparições marianas, e, por meio da comparação com as aparições contemporâneas, constatamos que parte dos elementos que compõem os fenômenos da atualidade estão 
presentes há séculos neste tipo de manifestação - vários deles são inclusive anteriores ao momento de auge destas manifestações durante o século XIX. Dessa forma, a leitura da bibliografia sobre as aparições na idade média e na idade moderna nos permitiu perceber, por um lado, a longa duração dos elementos presentes nas aparições contemporâneas e, por outro lado, nos ajudou na compreensão dos sentidos atribuídos a estes elementos na atualidade. Ou seja, o método comparativo nos possibilitou a percepção da longa duração das características que compõem as aparições marianas contemporâneas, facilitando a análise da ressignificação destes elementos na atualidade.

No entanto, para a apreensão do sentido dos elementos simbólicos das aparições foi também fundamental a análise do discurso dos participantes - peregrinos e videntes - e das mensagens transmitidas por Nossa Senhora. Assim, através da análise das diversas “falas” presentes nos fenômenos, compreendemos os sentidos atribuídos a seus elementos simbólicos - analisamos o que os participantes consideram como a "fala de Maria”, a mensagem em si, e também as interpretações dadas a elas, tanto pelos videntes como pelos participantes dos cenáculos.

Dessa forma, foram utilizados vários recursos e combinações entre eles para a elaboração deste trabalho: a observação dos rituais - em que consideramos o comportamento e as das falas dos participantes - a análise das conversas e das entrevistas dos fiéis - buscando compreender as conexões entre os participantes, bem como os sentidos dados por eles aos elementos simbólicos presentes nas aparições. Ou seja, procurou-se combinar as entrevistas referentes às aparições com as observações diretas do comportamento dos fiéis nos rituais - especialmente as falas do vidente e da Virgem e as interpretações dadas a elas. Além disso, foi levado em conta o material produzido sobre a aparição de Jacareí e também sobre outras manifestações - fornecidos pelos peregrinos ou adquiridos na barraca do Cenáculo - bem como sites católicos indicados pelos participantes. Por fim, a esta análise de campo foi acrescentada a leitura de documentos produzidos pelos representantes da Igreja: encíclicas, documentos teológicos, processos e pareceres sobre as aparições "modernas", sendo que o cruzamento entre todas estas informações nos trouxe as reflexões que embasam este trabalho. 


\section{PRIMEIRO CAPÍTULO}

\section{REDES E PEREGRINAÇÕES: A CIRCULAÇÃO NAS MANIFESTAÇÕES MARIANAS}

Dois aspectos nos chamaram a atenção quando começamos a analisar as aparições marianas: a circulação das manifestações e a circulação de pessoas para os Cenáculos - rituais em que acontecem as manifestações. Nosso primeiro esforço, então, foi de sistematizar toda a mobilização que caracterizava estes fenômenos.

Se, por um lado, essa circulação tem características de peregrinação, pois se trata da locomoção de pessoas para os locais onde ocorrem aparições da Virgem, por outro lado, porém, não se trata apenas de mobilidade de pessoas para um Santuário. As movimentações de pessoas - que chamaremos de peregrinação - têm como destino os rituais em que acontecem as manifestações de Nossa Senhora e que, no caso das aparições atuais, nem sempre possuem um local fixo. Ou seja, Nossa Senhora entra em contato com seus "mensageiros” no local onde eles estiverem. As peregrinações são realizadas para rituais, que no caso das aparições da Nossa Senhora são denominados Cenáculos Marianos². Parte deste capítulo será dedicada à compreensão das características das peregrinações para essas manifestações.

Antes, devemos destacar que essas manifestações são marcadas pela fluidez, não somente no que se refere ao espaço - ocorrendo onde estiverem os peregrinos - como também no tempo, sendo que várias delas não possuem uma periodicidade fixa para a sua realização. Para serem realizadas dependem da eficiência de uma rede, bastante ampla, que se articula para a organização do Cenáculo responsabilizando-se pela divulgação, contatos e financiamento dos rituais. Assim, a outra parte do capítulo será dedicada a destrinchar e caracterizar a intricada rede que articula as peregrinações e as movimentações das manifestações da Virgem Maria.

\footnotetext{
${ }^{2}$ Apesar do contato com Nossa Senhora ocorrer onde o vidente estiver, notamos que a existência de um ponto de referência geográfico para as aparições permanece importante. Ou seja, mesmo com a mobilidade de videntes e manifestações, a constituição de Santuários nos locais de origem das aparições ainda ocorre. Essa questão será analisada em capítulo posterior.
} 
Começaremos pelas peregrinações e romarias, tema bastante caro aos antropólogos, tendo sido estudado a partir de diferentes paradigmas teóricos. Alba Zaluar, em seu clássico estudo sobre as festas no catolicismo popular, demonstra que as Romarias aos Santuários dos santos famosos vem em substituição à realização de festas e danças para os santos padroeiros, como cumprimento de uma promessa ou de um voto. Vale a pena detalhar um pouco o caminho traçado por essa autora, pois ela trabalha com elementos simbólicos de longa duração, que, por um lado, sofrem alterações em seu significado, sendo que estes novos significados são capazes de expressar relações sociais.

Zaluar realiza uma análise das práticas religiosas camponesas como "uma linguagem que expressaria as idéias dos agentes a respeito da oposição $e$ complementaridade existente entre as pessoas e entre os diversos grupos sociais” (1983:14), especialmente entre as classes sociais. Procura desvendar os padrões de relacionamento a partir da análise das práticas do catolicismo popular rural. Para isso busca compreender principalmente as festas e as promessas nesse universo de devoção. Assim, modificações nas relações de dominação entre as classes sociais poderiam acarretar alterações nessa linguagem - as práticas religiosas. Para essa análise utiliza-se de estudos realizados em cinco comunidades - estudadas por pesquisadores sob o paradigma teórico dos “estudos de comunidade” - que se encontravam em situações diferentes, em que as práticas rituais e as relações de dominação não eram idênticas, mas próximas. Ou seja, desde comunidades em que a situação de dominação pode ser considerada "tradicional rural” até outras comunidades em que o contato com a cidade e com relações de dominação de tipo capitalista era comum.

A autora demonstra que as festas e as promessas do catolicismo popular são práticas religiosas que, no final da década de setenta, estão passando por alterações em algumas das comunidades. Não nos cabe detalhar esse tema, mas nos interessa principalmente a análise das promessas, pois são elas que levam a autora a uma reflexão sobre as romarias aos Santuários. As promessas eram invocadas pelos devotos nos momentos de incerteza e para a cura de doenças, e, sob esse aspecto, as razões dos pedidos aos santos permanecem iguais em todas as comunidades estudadas, sendo que as alterações ocorrem na sua forma de pagamento. Nas comunidades mais tradicionais, elas eram cumpridas pela realização de uma festa ou de uma dança para o santo ao qual foi realizada a promessa, sendo sempre marcadas pela distribuição de comida farta e gratuita. Assim, as promessas eram cumpridas coletivamente - festas, danças, orações - 
e aproximavam parentes e vizinhos, reforçando os laços dos quais faziam parte em sua rede de relações. Embora pareça uma relação entre o santo e o promesseiro, são também relações dos homens entre si, e, como relações dos homens entre si, expressas no ritual da festa, representavam, num plano simbólico, as relações entre os que podiam assumir os papéis de controlador dos recursos e de protetor - que exerce, pois, a dominação. Nas palavras da autora: "As relações entre os membros das classes sociais básicas que compunham a sociedade local passavam a fazer parte da ordem universal das coisas. Conseqüentemente, o catolicismo popular, tal como praticado nas áreas tradicionais, sustentava os padrões de vida tradicionais do interior do Brasil, legitimando-os." (1983:96).

Já, por outro lado, nas comunidades em que as relações tradicionais entre os homens tinham se alterado, a promessa era paga por meio de uma Romaria a algum grande santuário. As localidades em que as promessas eram pagas por meio de Romarias eram caracterizadas pela crescente mobilidade dos lavradores e a fragilidade dos laços que os uniam aos parentes e vizinhos. Vários deles estavam inseridos em redes mais amplas, nas cidades próximas, com as quais estabeleciam relações comerciais e mesmo religiosas - como a participação nas grandes festas de santos - que já tinham se modificado, sendo marcadas não mais pela distribuição de comida, mas pela sua venda em barracas e em leilões. As promessas, pois, deixam de estar centradas nas dádivas de comida para a distribuição coletiva e passam a ser efetivadas pelas visitas às cidades santuários.

Esse novo tipo de promessa enfatiza o sacrifício pessoal do promesseiro, ou de alguma pessoa de sua família. Era, pois, oposta à festa, por não ser diversão, sendo muito destacadas as dificuldades que envolviam a viagem, sendo ela, por si só, percebida como um sacrifício pelos romeiros.

Assim, para Zaluar, alterações na prática ritual de cumprimento das promessas foram percebidas nos locais em que as alterações nas relações sociais também estavam presentes. A linguagem das práticas rituais expressava, pois, para os agentes, um outro tipo de sociedade, de oposição e complementaridade entre pessoas e/ou grupos sociais, não mais centrada na reciprocidade entre dominados e dominantes, mas já próxima das relações sociais capitalistas de dominação.

Esse estudo é bastante interessante, demonstrando que a promessa e a romaria adquirem sentidos e são legitimas em um determinado tipo de sociedade, em determinada situação social. A autora estabelece bastante bem as conexões e as 
mudanças nas práticas rituais e nas relações sociais, não concebendo as mudanças rituais como a conseqüência mecânica das alterações sociais, mas demonstrando que o sentido destas também deve ser buscado nas relações entre indivíduos e grupos sociais. Trabalha com elementos simbólicos duradouros, como a promessa, que passa, porém, por alterações em seu significado.

Esse tipo de análise estabelecido pela autora é passível de ser desenvolvido em sociedades de tipo tradicional, em que as relações sociais são estabelecidas, em sua maior parte, entre parentes e vizinhos, entre pessoas da mesma localidade, sendo poucas as relações que ultrapassem a comunidade. Para o contexto de nossa análise essa abordagem é importante por possibilitar contemplar a organização das peregrinações a partir dos grupos paroquiais, que possuem vínculos de parentesco e vizinhança, sendo a partir da mobilização destes vínculos que as peregrinações são realizadas.

Entretanto, como a peregrinação aos Cenáculos de aparições marianas tem novas configurações e sentidos, pois não se refere mais às sociedades de tipo tradicional rural, como as analisadas por Zaluar, mas às sociedades complexas, aos grupos urbanos, inseridos no contexto de intensa renovação tecnológica que afeta as redes de sociabilidade, tornando os vínculos e os contatos entre os indivíduos bem mais extensos. Referem-se, pois, a uma sociedade em que as relações sociais estão menos restritas a grupos de localidade e vizinhança, possuindo conexões internacionais, estabelecidas através dos meios de comunicação, principalmente por redes de televisão e internet. Assim, esse tipo de análise, apesar de importante, não é suficiente para a compreensão da circulação de pessoas e manifestações marianas. Esse tema será detalhado a seguir.

Antes de analisarmos as peregrinações na atualidade, vale a pena destacar algumas características importantes das peregrinações "tradicionais”. Duas características são recorrentes nas peregrinações, observadas por vários autores - no trabalho de Zaluar elas já estavam presentes, sendo confirmadas em outros trabalhos, como o realizado por Carlos Steil sobre as peregrinações ao Santuário de Bom Jesus da Lapa, na Bahia - os votos e os milagres e a centralidade do sacrifício.

Os votos e os milagres são as razões mais comuns para a peregrinação. Sob esse aspecto, nas palavras do autor: "O voto traz para a pauta a questão da lealdade que se estabelece entre o romeiro e o Bom Jesus a partir do princípio de reciprocidade informal (...), estabelecia uma relação de aliança, características das sociedades camponesas tradicionais. (1996:101)”. Assim, as características das sociedades 
tradicionais, já destacadas por Zaluar nas práticas do catolicismo popular, estão presentes nesta peregrinação, embora essa autora tenha constatado que as peregrinações sejam uma nova forma de se cumprir os votos, característica das comunidades em que as relações entre os grupos sociais deixam de ser baseadas principalmente na reciprocidade, ou seja, em que suas características tradicionais estavam em transformação.

Sem entrarmos em detalhes desta discussão, importa retermos que as peregrinações são realizadas, principalmente, para o cumprimento dos votos, que estabelecem uma relação de aliança entre o peregrino e o Bom Jesus, que perdura por toda a vida do romeiro, ou seja, ele deve realizar a Romaria anualmente, pela época da festa do santo. Assim, o caráter duradouro dos votos permite o estabelecimento de redes de relações entre os romeiros, que se sobrepõem a outras redes em que estão inseridos, como de parentesco, vizinhança, entre outras. Inclusive, o autor demonstra que essas redes se estendem além da Romaria, organizando um calendário religioso nos locais de onde elas partem composto por uma série de rituais domésticos comunitários - como rezas, terços, entre outros. O elo, pois, não é apenas entre o romeiro e o santo, ultrapassando o contrato privado, pois "o romeiro entra numa rede de relações que o envolve, passando a partilhar um código de valores e categorias religiosos e morais com uma comunidade de peregrinos” (1996:102), e os votos, embora tenham partido de uma decisão pessoal na hora em que foram realizados, assumem uma dimensão social ao serem cumpridos a partir de uma romaria.

Assim, pelo trabalho de Steil também podemos perceber que as peregrinações estão inseridas e expressam redes de relações sociais, embora não seja o objetivo do autor analisar quais tipos de relações sociais são expressas por essa prática devocional. Dois aspectos desta análise, porém, devem ser destacadas: a fixidez espacial e temporal das peregrinações e dos rituais.

Nos casos analisados, os locais de peregrinação, chamados Santuários, possuem uma referência geográfica fixa. O espaço do Santuário é considerado sagrado pelos devotos, permanentemente sagrado, sendo realizadas peregrinações constantes para esses locais. Assim, embora existam períodos do ano que o número de peregrinos seja muito maior - na época da realização da festa do Santo padroeiro do Santuário -, trata-se de um espaço permanentemente sagrado, para os quais a peregrinação é 
constante $^{3}$. Ocorre a sacralização de um espaço concreto, palpável para os peregrinos, como colocado por Steil, em seu estudo sobre o santuário de Bom Jesus da Lapa “os romeiros vão demarcando um espaço sagrado que torna determinados lugares $e$ objetos mais próximos de Deus do que outros. A sua consciência está inextricavelmente associada ao território, de forma que o sagrado se apresenta sempre encharcado de concretude, ao alcance da vista e da mão, podendo ser tocado” (23:1996) Assim, a relação com espaço, considerado sacro devido à proximidade com as divindades, é central nessas Romarias.

Já no caso das peregrinações marianas contemporâneas, a relação com o Santuário deverá ser nuançada, pois, embora a constituição de Santuários nos locais de origem das aparições permaneça importante, as peregrinações ganham novas dimensões e configurações que ultrapassam o espaço sagrado fixo ${ }^{4}$. Nesse sentido, há peregrinações que são realizadas apenas no dia dos Cenáculos - rituais que acompanham o momento das aparições. Trata-se, pois, de peregrinações para rituais os Cenáculos - e não para os locais - Santuários. A aparição de Jacareí é ilustrativa desse fato, pois as peregrinações ocorrem apenas no segundo domingo do mês - o dia da realização do Cenáculo - sendo que nos demais dias o "Santuário" não passa de uma montanha como outra qualquer, sem a presença de pessoas no local. Inclusive, devemos desde já destacar que algumas manifestações marianas não possuem qualquer tipo de referência geográfica, sendo que seus mensageiros permanecem em constante circulação pelo mundo.

Notamos também diferenças no que se refere à temporalidade das Romarias. Segundo Steil, os votos estabelecem vínculos entre o peregrino e o Santo que perduram por toda a vida do devoto, e que formam um calendário de devoção a ser cumprido por ele todos os anos. No caso das peregrinações da atualidade este vínculo está ausente, como também está ausente a periodicidade para a realização de vários dos Cenáculos. Não são eventos fixos a uma data, sendo outros fatores que determinam a sua realização, impossibilitando o estabelecimento de um calendário de práticas rituais por parte do devoto e também para a realização de Romarias.

Outro aspecto importante em relação às peregrinações "tradicionais” é que as redes mobilizadas, analisadas pelos dois autores, são de proximidade, principalmente

\footnotetext{
${ }^{3}$ Como nos casos do Santuário de Nossa Senhora Aparecida ou do Pe Cícero, em que as Romarias são constantes e em qualquer época do ano, embora em número maior pela época das festas destes santos.

${ }^{4}$ A importância da constituição de um Santuário, nos moldes dos Santuários marianos europeus, para a imputação de legitimidade às aparições será analisado no capítulo seguinte.
} 
redes de vizinhança e parentesco, passíveis de serem apreendidas nas comunidades tradicionais estudadas por eles. Mesmo as redes mencionadas por Steil - no caso das peregrinações realizadas ao Santuário de Bom Jesus da Lapa - são estabelecidas a partir da comunidade de origem do peregrino - no caso estudado, os peregrinos partiam do vilarejo de São Miguel, na Bahia. Assim, Zaluar e Steil consideram “redes” as relações de parentesco, vizinhança e religiosas estabelecidas nas comunidades de origem dos peregrinos.

Nesse sentido, as peregrinações para as manifestações marianas contemporâneas possuem semelhanças com as romarias tradicionais, pois as excursões partem das paróquias de origem dos peregrinos, sendo que os contatos para a participação são estabelecidos por meio das relações religiosas locais, de vizinhança e de parentesco. Assim, as relações locais dos participantes são importantes nas peregrinações para as aparições, como demonstraremos a seguir.

Entretanto, apenas as relações de proximidade não são suficientes para explicar as peregrinações contemporâneas. Observamos que os contatos estabelecidos pelos peregrinos ultrapassam a sua localidade de origem e possuem o caráter de "rede" abordado na introdução de nosso trabalho - e não o desenvolvido pelos autores que analisaram as romarias no catolicismo tradicional. São relações mais extensas, para a realização dos cenáculos é preciso a mobilização de uma rede que ultrapassa os limites locais e paroquiais e que não está fixa a um determinado território.

A RCC possui papel central nessa rede, podendo ser considerada como a célula organizativa das peregrinações e responsável, em grande parte, pelo sucesso dos rituais. Essa rede possui elos, representados por pessoas que são contactadas e avisadas sobre a realização de Cenáculos e, a partir de então, difundem a informação entre suas relações religiosas locais (paroquiais), articulando pessoas e organizando peregrinações para os eventos. Assim, a partir dos contatos em rede, os elos organizam peregrinações a partir de suas paróquias de origem, e, quanto maior o número de peregrinos e excursões presentes, maior o número de elos e a extensão da rede mobilizada.

Dois aspectos, porém, devem ser destacados em relação a essa rede: por um lado o caráter temporário das articulações. Essa rede não está em contato constante, sendo articulada nos momentos anteriores à realização das manifestações, desarticulando-se a seguir e voltando a se articular em eventos posteriores, mas não necessariamente recompondo sua configuração anterior. 
Por outro lado, a amplitude e extensão dessa rede. Para compreender melhor devemos mencionar o caráter massivo dos rituais de manifestações marianas, com a presença de um grande número de pessoas e cuja importância é medida, justamente, pela quantidade de público. Novamente o caso da aparição em Jacareí é ilustrativo, pois o vidente se lamenta da diminuição do número de peregrinos nos últimos dois anos. Segundo ele, antes cerca de dez mil pessoas compareciam aos Cenáculos, e atualmente elas não passam de duas mil. Isso é percebido como uma decadência por ele. Assim, o sucesso do evento, por ser medido pela quantidade de pessoas presentes, depende da capacidade dos organizadores em articular essa rede.

Assim, embora os autores mencionados nos tenham dado pistas importantes sobre as redes de relação e sociabilidade que são mobilizadas nas peregrinações - relações de parentesco e vizinhança -, em nosso trabalho deveremos ir um pouco além, buscando compreender as relações extensas que dão sustentação às aparições.

Entretanto, também não podemos perder de vista que, somente essa rede extensa, articulada por pessoas e grupos distantes geograficamente, não explica as peregrinações aos Cenáculos marianos, sendo que as relações locais permanecem importantes na mobilização dessas práticas. Assim, na primeira parte deste capítulo nos deteremos nas relações locais e de vizinhança, centrais para a organização das peregrinações aos Cenáculos marianos. Já na segunda parte demonstraremos a importância e a configuração de uma rede de manifestações de Nossa Senhora, extensa e desterritorializada, que é articulada para a realização dos eventos e que contacta seus elos para a organização das peregrinações.

\section{1) A circulação das pessoas: peregrinação}

A origem dos freqüentadores dos Cenáculos foi um dos primeiros fatos que chamaram a nossa atenção nas aparições de Nossa Senhora. Eles vêm de diferentes locais, participando dos rituais em excursões de variadas cidades, sendo apenas uma minoria de moradores do município em que ocorre o evento. São, pois, peregrinos pessoas que se deslocam de suas cidades para presenciar a aparição.

Antes de analisarmos esse público, devemos realizar uma breve descrição do ritual e do cenário que as acompanha, para melhor caracterizar esse evento. Descreveremos os cenáculos das aparições de Nossa Senhora no Município de Jacareí, 
no Vale do Paraíba, interior de São Paulo, a aparição Mariana com a qual mantivemos maior contato durante nossa pesquisa.

\section{a) A aparição de Nossa Senhora em Jacareí}

A aparição de Nossa Senhora em Jacareí, interior de São Paulo, teve inicio no ano de 1991. Seu vidente era o então adolescente Marcos Tadeu, de treze anos. A primeira visão ocorreu numa tarde, quando o menino voltava para a casa após a aula, e desde então se repete todo o dia, quando a "senhora do céu" lhe transmite alguma mensagem. Nesse capítulo nos deteremos nos chamados cenáculos, rituais mensais, realizados aos segundos domingos de cada mês, durante os quais, segundo os fiéis, aconteceria a aparição e a transmissão de uma mensagem especial.

Atualmente os cenáculos atraem cerca de 2000 fiéis mensalmente, vindos de várias localidades, principalmente do estado de São Paulo. A grande maioria dos freqüentadores vem em excursões, de ônibus ou vans. Os organizadores do cenáculo consideram esse número de freqüentadores muito pequeno, pois, em seu auge, no final da década de noventa, os cenáculos chegavam a contar 20.000 pessoas, vindos de todo o Brasil e inclusive de outros países da América do Sul, como Argentina e Uruguai. Nesse momento o vidente Marcos Tadeu era uma figura de destaque na mídia, sendo objeto de reportagens de revistas de repercussão nacional - como a Veja e a Época - e de programas televisivos - como o Programa do Gugu.

Segundo os freqüentadores, o principal motivo do esvaziamento dos cenáculos foi a intensa perseguição estabelecida pela hierarquia católica, principalmente o bispo local, contra as aparições. Tanto que, atualmente, os padres das proximidades são proibidos de participarem dos rituais - o último padre que aderiu às aparições foi transferido - e muitos deles falam contra as aparições em seus sermões, alguns negando a comunhão aos seguidores de Marcos. Entretanto, não se trata do objetivo neste capítulo a análise das relações e conflitos entre os seguidores e a Igreja local, que deverá ser realizada em capítulo posterior.

Neste ponto devemos falar brevemente da cidade de Jacareí e do local das aparições. Jacareí está situada no Vale do Paraíba paulista, no eixo Rio - São Paulo, as margens da rodovia Presidente Dutra, à aproximadamente $70 \mathrm{Km}$ da cidade de São Paulo. Possui características de uma cidade média, com aproximadamente 120.000 habitantes, algumas indústrias importantes. Sua população encontra-se empregada 
principalmente nessas indústrias, embora o comércio e os serviços da cidade também empreguem uma porcentagem significativa de sua mão de obra. Além disso, muitos estão empregados na cidade vizinha - São José dos Campos, maior cidade do Vale do Paraíba e também a mais industrializada, - principalmente na indústria.

Os cenáculos são realizados na zona rural, mas bastante próxima da cidade - a menos de dois quilômetros da zona urbana de Jacareí - estando em contato muito estreito com ela e apresentando, inclusive, problemas que podem ser considerados urbanos, como a violência ${ }^{5}$.

Já o público dos cenáculos advém majoritariamente da zona urbana, não apenas de Jacareí, mas de outras cidades, como São José dos Campos, São Paulo, Itu, Caçapava. Além disso, são vinculados à práticas religiosas características do contexto urbano, como o movimento Renovação Carismática Católica. Detalharemos um pouco mais o ritual das aparições marianas - os Cenáculos.

\section{Os Cenáculos}

Os cenáculos ocorrem todos os segundos domingos de cada mês, pela manhã, possuindo aproximadamente quatro horas de duração, entre as nove e treze horas. O ritual é realizado ao ar livre, no alto de uma pequena montanha. Esse é o dia de peregrinação para o local, sendo que, nos demais dias do mês a montanha não é freqüentada pelos devotos.

A primeira impressão é a de um grande piquenique, pois os participantes levam uma série de apetrechos consigo - cadeiras de praia, toalhas de mesa, esteiras, guarda-sóis, cestas com alimentos. É justamente um piquenique que presenciamos nas primeiras horas do cenáculo. Vários pequenos grupos reunidos em volta de uma cesta de comida, em suas cadeiras, lonas, esteiras...

Duas características importantes podem ser apreendidas a partir desta primeira observação: o grande número de pessoas presentes, que, segundo os organizadores, era de aproximadamente mil pessoas, e a aparente indistinção entre elas -

\footnotetext{
${ }^{5}$ Inclusive, a mudança no horário de realização dos cenáculos, até dois anos atrás eles eram realizados a partir da seis horas da tarde, aos sábados, entretanto, vários casos de violência começaram a ser registrados devido a escuridão - roubo e arrombamento dos carros dos visitantes, assaltos a fiéis durante o ritual - passando então a serem realizados aos domingos pela manhã, mesmo assim, diante da presença de vários seguranças particulares do santuário.
} 
todos fazem parte do público, sendo que a única pessoa que se destaca no ritual é o próprio vidente, que conduz todas as etapas do Cenáculo.

No "monte”, em frente à capela que está sendo construída, é instalado um pequeno altar improvisado, em sua parte mais alta e visível, onde permanece o vidente Marcos Tadeu. Neste altar há uma imagem de Maria - elaborada de acordo com as descrições de Marcos - e também microfones e caixas de som, permitindo que as orações sejam ouvidas por todos os participantes. O vidente permanece no altar durante todo o Cenáculo, e logo com a chegada das primeiras pessoas inicia suas orações - uma série de terços - terço da libertação, de Nossa Senhora desatadora dos nós, entre outros, que se estende durante todo o ritual, cessando apenas no momento em que Maria lhe aparece e lhe fala, por volta do meio dia. Esse é o auge do ritual, em que todos os presentes permanecem de joelhos, havendo um silêncio absoluto no local, sendo que o único ruído que se ouve é a voz do vidente, “falando com Nossa Senhora”.

Entremeando as orações, Marcos faz referência constante a mensagens proferidas em outras aparições marianas, principalmente de divulgação internacional, estabelecendo conexões e aproximações com as mensagens de Jacareí. A menção a outras aparições marianas é uma constante não apenas durante o cenáculo, mas também entre seus participantes. Exemplo disso é um livro publicado pelas pessoas mais próximas ao vidente - que chamarei de grupo de apoio - cujo título significativo é: “As aparições de Maria em Jacareí: a continuação de Fátima e a conclusão Garabandal”, estabelecendo não apenas uma aproximação entre essas aparições, mas uma continuidade entre elas.

Chama também a atenção o consumo de produtos religiosos durante o cenáculo. Há uma barraca instalada em um “canto” da montanha, na qual os presentes consomem produtos religiosos referentes a aparições de Nossa Senhora. Enquanto Marcos conduz as orações, fiéis aguardam na fila da barraca, permanecendo cerca de uma hora na espera antes de poderem comprar os produtos oferecidos, associados às aparições da Virgem, não apenas a de Jacareí. Os artigos consumidos em maior escala são as medalhas e terços das aparições locais, mas também há uma grande variedade de produtos de outras aparições marianas, principalmente DVDs, CDs e livros, referentes aos fenômenos internacionais, como Fátima, Garabandal, Medjugorge e Lourdes, e também a pequenas aparições locais, como Muriaé e Niterói. 
A observação do comportamento dos freqüentadores na banca do Cenáculo também demonstra a conexão estabelecida entre a aparição Jacareí e outras aparições marianas. A procura por produtos de outras aparições é um exemplo, mesmo que não comprem, os fiéis se informam sobre variados produtos, comumente perguntando aos vendedores sobre determinado fenômeno - sobre o qual há algum produto a venda - sua importância, etc. Inclusive, a conversa dos consumidores demonstra conhecimento e conexões sobre variadas aparições. Na fila, por exemplo, preenchem o tempo de espera trocando impressões e informações sobre diversas manifestações marianas.

Há, pois, interesse dos participantes sobre várias manifestações do mesmo tipo. Nesse sentido, o Cenáculo de Jacareí pode ser percebido como um dos "pontos de confluência” de uma rede de manifestações marianas, pela qual circulam manifestações, peregrinos, informações, práticas rituais, produtos religiosos e mensagens. As orações proferidas, bem como os produtos vendidos na barraca do cenáculo, nos dão pistas sobre as relações e conexões existentes entre várias manifestações marianas, desde as de respaldo internacional - como Fátima e Medjugorje, até algumas pequenas aparições brasileiras.

Essas relações e conexões tornaram-se ainda mais evidentes quando nos centramos nas peregrinações realizadas por parte do público dos Cenáculos de Jacareí, que se estendem para outras manifestações de Nossa Senhora. Inclusive, o próprio vidente - Marcos Tadeu - já havia peregrinado para outras aparições, sendo que mantém contato com outros “mensageiros” de Maria.

Na verdade, conforme desenvolvíamos nosso trabalho, mais as relações entre peregrinos de diferentes localidades pareciam estar imbricadas. O contato e a conexão entre manifestações marianas foram se tornando evidentes, caracterizando-se como uma rede, não comum a todos os peregrinos, mas apenas alguns deles, aqueles que possuíam algum papel de destaque - seja no movimento carismático, na organização das excursões ou nas aparições - pertencendo ao grupo de apoio e o próprio vidente. Optamos por chamar estes indivíduos de elos, pois eles estabeleciam as conexões entre essa rede e os pequenos grupos paroquiais, em que também estavam inseridos. Nos deteremos agora nas características do público. 
Os freqüentadores dos cenáculos vêm de diferentes locais, participando dos rituais em excursões de variadas cidades, sendo apenas uma minoria de moradores do próprio município. Há três tipos ou grupos de freqüentadores dos cenáculos: o grupo de apoio, os participantes assíduos e os participantes esporádicos.

O grupo de apoio é constituído pelos seguidores que acompanham de perto o fenômeno das aparições, e não apenas os cenáculos, sendo eles, justamente, os responsáveis pela sua organização - montagem do altar, vendas na barraca, segurança, entre outros. Todos moram atualmente em Jacareí ou nas cidades vizinhas - sendo que uma parte deles deixou suas cidades para se dedicarem ao fenômeno - e possuem uma certa coesão e mesmo unidade, especialmente no que se refere às práticas religiosas de seus membros, que basicamente apenas freqüentam as atividades promovidas pelo próprio grupo, com exceção da missa. Autores que analisaram outras aparições marianas também notaram a presença de um grupo responsável pela organização e divulgação do evento ${ }^{6}$.

Em Jacareí, o grupo de apoio não participa de outras atividades religiosas da Igreja por serem constantemente criticados por outros católicos, principalmente devido à negação da veracidade das aparições por parte das autoridades religiosas locais ${ }^{7}$. Já a freqüência à missa, diariamente, está relacionada à crença na necessidade do recebimento do sacramento da comunhão - segundo eles, professado pela Virgem ${ }^{8}$. O grupo de apoio desta aparição é constituído por aproximadamente vinte pessoas, não existindo distinções ou papéis definidos entre eles, mas apenas funções e responsabilidades organizativas durante o Cenáculo. Inclusive, durante o evento não percebemos essas pessoas em destaque em nenhum momento, sendo que apenas o vidente conduz o ritual - ele realiza as orações, tem a visão e faz a interpretação dela. Ou seja, somente ele detém a palavra.

\footnotetext{
${ }^{6}$ Há menções sobre esses grupos nos trabalhos de Steil, sobre a aparição de Taquari, de Mariz, sobre a aparição de Niterói, e de Almeida, sobre a aparição de Piedade das Gerais.

${ }^{7}$ As autoridades católicas locais promoveram um combate aberto aos cenáculos, proibindo, em alguns casos, os paroquianos de participar deles.

${ }^{8}$ Existe uma relação de forte tensão entre o grupo de apoio e os demais católicos, pois estes questionam a veracidade das aparições - com o aval e apoio da hierarquia da Igreja local - e, em muitos casos, procuram convencer os organizadores a se afastarem do fenômeno. A influência da hierarquia da Igreja sobre esse fenômeno não pode ser desconsiderada, e será analisada em capítulo posterior, sendo que mesmo a constituição do público está relacionada a essa tensão, pois são poucos os seus freqüentadores que fazem parte da diocese, a grande maioria é proveniente de cidades mais distantes, em que a aparição é pouco conhecida - e não combatida - pelos sacerdotes.
} 
Os dois outros tipos - participantes assíduos e participantes esporádicos possuem em comum o fato de não serem moradores da localidade, tendo realizado uma peregrinação ao Cenáculo. Constituem a grande maioria dos presentes, já que o grupo de apoio é composto de poucos membros. Esses dois grupos também estabelecem relações diferenciadas com os fenômenos.

Os participantes assíduos são aqueles que participam com freqüência regular a uma manifestação Mariana específica - como, por exemplo, as aparições de Jacareí. Essas pessoas são, em geral, organizadoras das excursões para a sua manifestação de devoção. Devemos destacar que a maior parte do público dos cenáculos - rituais em que ocorrem as aparições de Maria - é composta de pessoas que vêem em excursões organizadas por algum membro da comunidade. Em vários casos esse organizador é um participante assíduo. Entretanto, isso não é uma regra, pois alguns organizadores também são esporádicos, tendo obtido informação sobre alguma aparição mariana, se interessado por ela e realizado uma excursão, como também realiza para outras manifestações.

Inclusive, uma das características dos participantes assíduos é o interesse por outras manifestações de Nossa Senhora. Esse interesse foi observado pela busca de informações sobre eles - conversas, jornais, sites, fitas cassete - ou por participações em outras manifestações marianas. Ou seja, apesar de devotos da aparição de Jacareí, também freqüentam e se informam sobre várias outras manifestações do mesmo tipo, ou seja, estabelecem conexões com outros fenômenos.

O segundo tipo - os participantes esporádicos - não possui uma freqüência regular a uma manifestação mariana. São eles os participantes das excursões organizadas, geralmente, por participantes assíduos, que tomam contato com esses fenômenos a partir de relações católicas em suas paróquias ou em grupos de vizinhança. No caso das aparições de Jacareí, esse tipo de participante é cada vez mais escasso. Quando iniciamos nosso trabalho de campo, em 2003, eles constituíam a maioria dos freqüentadores, mas já no ano de 2008, com a diminuição significativa na freqüência ao local, os participantes esporádicos eram cada vez mais raros, sendo a maioria dos participantes formada por freqüentadores assíduos, que participavam dos Cenáculos há alguns anos.

Foi a partir da análise do público dos cenáculos das aparições marianas que percebemos que a circulação de pessoas é parte importante e constituinte dessas manifestações na atualidade. No caso de Jacareí, por exemplo, a grande maioria do 
público dos cenáculos vem de outros municípios, ou seja, peregrinavam para participar da aparição. Devemos, então, compreender como são realizadas estas peregrinações, que têm origem nas paróquias - as excursões, na maior parte dos casos, são organizadas entre grupos pertencentes a uma mesma paróquia. Para isso partimos das práticas rituais dos peregrinos, sendo por meio dos contatos estabelecidos nos rituais que são organizadas as peregrinações. Vale a pena destacar que foi também a partir da sistematização das práticas rituais dos peregrinos que a importância do movimento carismático nas manifestações de Nossa Senhora foi evidenciada, sendo pelos contatos estabelecidos em seus grupos de "base” que se organizam as Romarias aos Cenáculos marianos.

Entretanto, outra característica do público nos chamou a atenção: Os peregrinos, mesmo quando participantes assíduos de uma manifestação de Nossa Senhora, não peregrinavam exclusivamente para sua denominação de devoção, mas também para outros fenômenos semelhantes. Os membros do grupo de apoio e os participantes assíduos, principalmente, costumavam peregrinar para outros eventos, sendo Jacareí, pois, um dos “pontos de confluência” de uma rede de aparições marianas. Assim, a peregrinação “em rede” foi um aspecto que nos chamou a atenção nas aparições de Maria, pois, parte do público não era participante exclusivamente de uma manifestação, mas também de outras manifestações marianas, que mantinham contato entre si. Para entender essas movimentações devemos compreender a configuração dessa rede e os contatos de seus membros.

\section{c) A prática ritual dos peregrinos}

Analisamos as práticas rituais dos peregrinos que participavam dos cenáculos através de excursões realizadas por suas paróquias de origem, sendo que, a partir delas pudemos perceber as relações religiosas estabelecidas por eles.

Os peregrinos pesquisados possuíam um amplo leque de práticas religiosas, havendo, porém, várias em comum entre eles, aproximando-se de outras redes católicas - principalmente da RCC, composta por grupos de oração, terços da libertação, retiros, circulação de imagens de Maria pelas residências, terço da Virgem Desatadora dos Nós, além de participações em rituais com manifestações marianas aparições, locuções e milagres - entre outras práticas rituais. Assim, analisando as práticas rituais dos peregrinos das manifestações marianas pudemos entender as 
relações religiosas dos peregrinos de diferentes origens e de diferentes aparições marianas. Começaremos por uma excursão vinda de Itu para Jacareí.

Vilma e Maria são moradoras de Itu, estado de São Paulo, e participam mensalmente dos cenáculos em Jacareí, quando, segundo elas, ocorre a aparição de Maria ao vidente Marcos Tadeu. Todo segundo domingo do mês um grupo de fiéis da cidade realiza uma excursão para Jacareí. O organizador da excursão é Nei, e, apesar da freqüência das excursões partidas de Itu, segundo ele, apenas um grupo de cerca de dez pessoas participam mensalmente dos rituais, sendo o restante do ônibus preenchido por participantes esporádicos, que eventualmente peregrinam para o Cenáculo.

Nei, além de organizar as excursões, é freqüentador assíduo das missas de sua paróquia em Itu, organizando as excursões a partir de recados e contatos durante as cerimônias. Já as redes de relações católicas das outras duas entrevistadas - Vilma e Maria - é mais ampla. Semanalmente, freqüentam um grupo de orações da RCC e fazem parte de um grupo de circulação da imagem de Nossa Senhora nas residências, além da freqüência à missa. Também rezam diariamente o terço da libertação e o terço da misericórdia, em casa ou nas casas dos vizinhos, muitos deles também participantes dos grupos de oração. Esporadicamente realizam excursões a Aparecida. Possuem informações sobre outras aparições marianas no Brasil- mencionaram Muriaé, em Minas Gerais - mas não as freqüentam devido a grande distância.

Apesar de Nei não participar desses rituais, é a partir deles que a notícia sobre a excursão, bem como informações sobre o fenômeno, relatadas pelos praticantes que já peregrinaram, são divulgadas. Assim que o aviso era dado nas missas, era, em seguida, repetido por peregrinos assíduos em seus grupos de oração e grupos de terços, ocorrendo uma divulgação "boca a boca" da excursão, sendo a partir daí que a peregrinação mensal era realizada.

Outro grupo de peregrinos pesquisado era vinha da cidade da São Paulo, e possuía constituição semelhante à observada no grupo de Itu, possuindo uma organizadora, Dona Cláudia, que participava mensalmente das aparições de Jacareí. Dona Cláudia estava inserida em uma ampla rede de relações católicas, sendo também catequista em sua paróquia e líder de um grupo de oração. Além disso, também freqüentava, sempre que possível, as rezas de terços - da libertação, de Nossa Senhora desatadora dos nós, entre utros, realizados na vizinhança. A partir de seus contatos nessa rede reunia peregrinos para a excursão mensal à Jacareí. 
Com relação ao grupo de São Paulo, também conversamos com algumas participantes esporádicas, como Clara. Ela participa de várias práticas em comum com os peregrinos assíduos dos cenáculos, mas, como é também catequista, durante o período letivo tem outros compromissos com a paróquia aos domingos, participando das excursões apenas durante as férias escolares. Com relação as suas outras práticas religiosas, elas se repetem, sendo as já comentadas - missa, grupo de oração e terços, recebendo nestes locais as informações sobre as peregrinações a Jacareí. Mesmo nos meses que não participa, sabe notícias e detalhes da excursão, adquiridas a partir de seus contatos com membros das práticas religiosas das quais participa, sendo que os maiores detalhes sobre a aparição são obtidos em seu grupo de oração.

Os dois grupos de peregrinos tinham como principal local de peregrinação a montanha da aparição de Maria na cidade de Jacareí. Apesar de vindos de diferentes paróquias e dioceses - vale lembrar que distantes de Jacareí - possuíam práticas religiosas em comum. Essas práticas religiosas, excluindo-se as ligadas ao catolicismo oficial sacramental - as missas e catecismos - apontavam para o movimento carismático. A grande maioria dos peregrinos participava dos rituais característicos desse movimento - especialmente os grupos de oração - ou de práticas religiosas não exclusivas da RCC, mas amplamente divulgadas por ela, como os terços da libertação e outros semelhantes. Como demonstramos, vários membros assumiam papéis ativos em seus grupos paroquiais, sendo a partir deles que organizavam as Romarias.

Entretanto, esta é apenas uma relação das práticas rituais estabelecidas em suas paróquias, pois também possuíam vínculos e haviam participado de peregrinações para várias manifestações de Nossa Senhora, especialmente daquelas relativamente próximas de suas cidades. Podemos citar exemplos de manifestações visitadas por pessoas dos dois grupos mencionados, entre elas: Vinhedo, no Estado de São Paulo, como vidente Paulo; Muriaé, Minas Gerais, com a vidente Mirna; Piedade, em Minas Gerais, com a vidente Marilda; Niterói, no Rio de Janeiro, com o vidente Ricardo. Inclusive, a peregrinação para Cenáculos com a participação de mensageiros internacionais também foi observada, como rituais com a presença de Pe Gobbi e Vassula Ryden, dois confidentes marianos de muito destaque no Brasil, como veremos a seguir.

Importa mencionar que foi por meio da observação dessas práticas rituais que pudemos constatar a proximidade delas com o movimento carismático, através dos 
rituais da RCC “de base” presentes em todas as paróquias e responsáveis pela expansão do movimento, especialmente os grupos de oração ${ }^{9}$, terços e imagens itinerantes.

A proximidade entre o movimento carismático católico e as aparições de Nossa Senhora foi observada por autores que pesquisaram as aparições marianas ou o movimento carismático - como Tânia Almeida, Cecília Mariz e Carlos Steil. Tânia de Almeida (2003) percebe a presença importante dos carismáticos na aparição de Nossa Senhora na cidade de Piedade das Gerais, e Carlos Steil, ao estudar um santuário dedicado a uma aparição de Maria em Taquari, no Rio Grande do Sul, destaca a centralidade dos carismáticos nesse fenômeno. Já Cecília Mariz constata a devoção às aparições marianas por parte dos carismáticos ao estudar esse movimento. Também em meu trabalho de mestrado, sobre as práticas rituais da RCC, havia notado a importância da devoção a Nossa Senhora nesse movimento, e, além disso, a constante realização de excursões para locais ou santuários onde ocorriam aparições de Nossa Senhora por grupos de carismáticos.

Assim, uma primeira característica da relação entre os carismáticos e as aparições marianas, não mencionada pelos autores que estudaram estas manifestações, é a importância de seus rituais de base, aqueles que estão organizados nas paróquias grupos de oração - e entre grupos de vizinhança - terços - para a realização das peregrinações e, portanto, para a participação nos fenômenos. Inclusive, mesmo quando os participantes destes rituais carismáticos não peregrinam, ao menos recebem informações sobre as manifestações marianas a partir deles.

\section{d) Os Rituais Carismáticos Paroquiais e as Aparições Marianas}

Parcela significativa do público das aparições de Nossa Senhora é adepto de práticas rituais carismáticas e/ou divulgadas a partir da RCC. Autores que estudaram a RCC demonstram que os carismáticos possuem uma devoção especial à Virgem Maria, sendo ela figura central e de destaque nesse movimento. Assim, a devoção dos carismáticos a Nossa Senhora explica, ao menos em parte, a presença significativa de seus praticantes nas manifestações de Maria.

Vale a pena retomarmos a devoção Mariana na RCC. A devoção à Virgem Maria na RCC está relacionada ao sistema simbólico carismático. A bibliografia

\footnotetext{
${ }^{9}$ Os grupos de oração são rituais semanais da RCC, estando presentes em várias paróquias do Brasil. Cada grupo de oração possui um coordenador, que são pequenas lideranças do movimento nas paróquias.
} 
especializada refere-se à devoção a Nossa Senhora neste movimento como uma exigência da cúpula da Igreja. Segundo Prandi (1996) e Souza (2001), esta foi uma forma de demarcar a identidade católica da RCC estabelecida pela hierarquia da Igreja, afastando-a do pentecostalismo ${ }^{10}$.

A devoção a Virgem aproxima a RCC da espiritualidade católica. Em nosso trabalho de mestrado demonstramos como ela possui um lugar central nos principais rituais carismáticos - os grupos de oração e os retiros - havendo momentos especiais de louvor a Maria, que ocupavam parte importante desses rituais.

Há um processo de resignificação dos símbolos católicos referentes a Nossa Senhora no sistema de crenças carismático (Sales, 2003). As práticas rituais marcadas pela emocionalidade, embasadas no contato e comunicação com as figuras divinas, característica da RCC, são observadas na devoção carismática à Virgem. Tanto que, um dos momentos centrais, de maior emocionalidade durante os rituais carismáticos, é o chamado louvor à Virgem Maria. Essa devoção, pois, apesar de ter sido de certa forma imposta pela hierarquia da Igreja e de reforçar a identidade católica da RCC, adquire novos significados, inserindo-se nas práticas rituais características desse movimento.

No momento do louvor a imagem de Nossa Senhora adentra o salão em que está sendo realizado o ritual. Há muita emotividade entre os carismáticos: a imagem da Virgem passa entre os presentes, por cada um deles. Os carismáticos têm nesse momento expressões de carinho para com essa imagem. Eles a tocam, abraçam, beijam, pegam-na no colo, como se estivessem diante de alguém muito próximo, uma mãe realmente. Existe, pois, a crença no poder de Nossa Senhora em “levar” os sofrimentos, a angústia, a dor, e até os pecados dos fiéis presentes. Quando a imagem passa, cada um dos fiéis fala a Nossa Senhora seus sofrimentos e pecados, acreditando que serão libertados deles após essa “conversa com Nossa Senhora”.

Trata-se de um encontro pessoal com a Virgem. A imagem passa pelas mãos de cada um dos presentes, que a toca e conta a Nossa Senhora todos seus problemas e pecados, acreditando que ela possa levá-los, tornando-os libertos a partir de então. Os carismáticos vivenciam uma experiência autônoma e imediata de contato e

\footnotetext{
${ }^{10}$ A proximidade entre a RCC e o pentecostalismo foi notada por autores que estudaram o movimento, como também pela Igreja Católica, especialmente no que se refere à importância dos chamados "dons do Espírito Santo” em ambas as religiosidades. Já pentecostalismo, tanto em sua forma clássica como o neopentecostalismo, não aceita a devoção a Virgem Maria, característica do catolicismo.
} 
comunicação com o sagrado, exclusivamente sensitiva, nada racional. Os fiéis consideram-se pertencentes ao movimento após esse primeiro contato emocional e sensitivo com Nossa Senhora. A conversão, pois, é estabelecida através do sentimento, do toque. O louvor a Maria demonstra não apenas a devoção dos carismáticos, mas a centralidade do contato direto e imediato com as figuras divinas, sendo a experiência do contato, revivida a cada ritual, que justifica a permanência dos praticantes no movimento, que os estimula a voltarem a participar dos rituais. A importância da experiência do contato será analisada com mais detalhes, inclusive no que se refere às aparições; por hora basta destacar a sua presença e centralidade entre os carismáticos.

A freqüência às aparições de Nossa Senhora por fiéis da RCC pode ser considerada como mais uma busca de contato direto e pessoal com a santa, pois, nestes locais Nossa Senhora está presente inclusive visualmente para alguns. Nas aparições são freqüentes os relatos de devotos sobre odores de rosas no momento das visões, ou sobre o "sentir o toque de Maria em seus corações", ou seja, consideram que qualquer um dos presentes pode vivenciar experiências pessoais que demonstrem a presença e o contato de Maria.

Além da centralidade em seus principais rituais - grupos de oração e retiros - os carismáticos são grandes divulgadores de outras práticas que possuem Maria como figura central, especialmente os terços e as imagens peregrinas da Virgem. No que se refere aos terços, como os já citados terço da libertação, de Nossa Senhora desatadora dos nós, da misericórdia - não devemos nos esquecer de que o Rosário, e o terço, são considerados as orações marianas por excelência -, eles têm em comum o fato de suas jaculatórias serem muito curtas e simples, o que facilita e torna a reza do terço mais rápida. A sua oração é muito incentivada nos rituais carismáticos, que exortam os participantes a rezá-los e a formarem pequenos grupos domésticos para sua oração Também são divulgados através da rede carismática de rádio e televisão “Canção Nova”, que possui um horário específico para a oração de cada um deles. No relato dos peregrinos notamos que a oração desses terços é uma prática comum, seja em casa sozinho, ou no ônibus, seja com a família ou com amigos ou vizinhos, e mesmo através da TV, durante a sua transmissão.

Já a circulação de imagens peregrinas de Maria é outra prática muito comum entre os carismáticos, realizada entre grupos de vizinhança, que recebem as imagens em suas casas, oferecendo-lhe pousada por uma noite e levando-a na noite seguinte para outro “pouso”, em alguma residência da vizinhança. Durante a mudança 
de "pouso" pode ser realizada uma pequena procissão ou rezado algum dos terços mencionados. O recebimento das imagens peregrinas em casa também foi constatado no relato de vários participantes das aparições.

Essas práticas rituais, apesar de pertencentes à RCC, são também características do catolicismo popular, sendo que, ao observá-las, as referências a essa religiosidade ficavam patentes - a reza do terço, seguida de uma pequena procissão que acompanha a imagem da Virgem é muito semelhante às práticas católicas populares, em que a devoção a Nossa Senhora, bem como a relação de proximidade com as imagens de Santos, é marcante ${ }^{11}$. Azzi (1978), estudioso do catolicismo popular, considera fundamentalmente dois aspectos dessa religiosidade: a devoção aos santos e seus ritos, como as procissões e as Romarias, e as orações e rezas conduzidas pelos leigos, sem a presença de sacerdotes. Ambas podem ser observadas nestas práticas rituais da RCC, apenas com a ressalva de serem realizadas em grandes centros urbanos, e não apenas em suas periferias - como as já analisadas continuidades das práticas rituais católicas populares entre migrantes, na periferia dos centros urbanos ${ }^{12}$. Presenciamos, por exemplo, terços e procissões em bairros nobres de São José dos Campos.

Assim, podemos pensar que essas práticas de devoção a Maria, apesar de presentes em um movimento relativamente novo no catolicismo, possui também um aspecto de continuidade. Algumas práticas de devoção a Nossa Senhora desenvolvidas pelos carismáticos, bem como as próprias aparições de Maria a videntes, não são novidade no catolicismo, pelo contrário, podem ser consideradas como eventos de longa duração. Essa dimensão das aparições é muito importante em nosso trabalho, sendo aprofundado em um dos capítulos da tese.

Por hora, devemos enfatizar que as essas práticas demonstram as relações estabelecidas pelos participantes das aparições, vinculadas ao movimento carismático, mas que vão além dele, como no caso de duas práticas referidas, os terços e as imagens

\footnotetext{
${ }^{11}$ Segundo Hoonaert (1974) o catolicismo popular se manifesta de diversas formas, através da construção de cruzes, oratórios nas casas e lugares públicos, ermidas, santuários; além de manifestações rituais, como Romarias e procissões de diversos tipos. Uma característica marcante desta religiosidade é seu aspecto profundamente devocional, manifestada principalmente através da devoção aos Santos Padroeiros e da crença em promessas e milagres, geralmente relacionados aos Santos e a Virgem Maria.
}

\footnotetext{
${ }^{12}$ Carlos Rodrigues Brandão (1986) faz referências à continuidade de práticas rituais do catolicismo
} popular entre camponeses que migram para as cidades. 
peregrinas, que, apesar de serem divulgadas e estarem relacionadas com a RCC, possuem muitos praticantes não carismáticos.

Assim, grande parte dos peregrinos das aparições marianas, sejam esporádicos ou assíduos, participam de práticas rituais da RCC. Essas práticas rituais são organizadas em torno da paróquia - grupos de oração - ou da vizinhança - terços e imagens peregrinas - que também são vinculados às paróquias. É por meio das relações e contatos estabelecidos nas práticas rituais relatadas, em suas respectivas paróquias, que as excursões são divulgadas e organizadas. Essa rede mobilizada pelas peregrinações se estende além da RCC - embora seja entre seus seguidores que possua maior densidade - pois fiéis não carismáticos são também tocados por ela.

Isso explica como fiéis não carismáticos sejam freqüentadores assíduos e organizadores de excursão, como é o caso mencionado de Nei, da cidade de Itu, que mensalmente organiza as excursões e as divulga durante a missa na paróquia. É esse o ponto de partida, que toca os carismáticos locais que, em seguida, “espalham” a notícia entre seus colegas de grupo de oração ou do terço, que as espalham entre outros conhecidos. Assim, Nei, que não se considera carismático, arregimenta peregrinos entre os carismáticos de sua paróquia.

A percepção que os participantes têm de suas atividades religiosas foi importante, pois nos levou a constatar dimensões das relações religiosas estabelecidas por eles. Assim, as relações religiosas de vários peregrinos estavam mais restritas à paróquia, sobrepondo-se, em muitos casos, a práticas e obrigações vinculadas a um catolicismo oficial, ou seja, as práticas e crenças estabelecidas oficialmente pela Igreja Católica, como a doutrinação das crianças e/ou de jovens de acordo com as regras e normas da CNBB. Algumas das participantes desempenhavam a função de catequistas ou de coordenadoras de jovens crismandos, além de participarem de outros rituais não oficiais - como grupos de oração, terços, entre outros. Esses peregrinos tinham em comum não apenas as práticas religiosas, mas o fato de suas relações religiosas serem mantidas com pessoas ou grupos pertencentes à mesma paróquia ou diocese, sendo que a própria peregrinação era realizada com pessoas ou grupos paroquiais.

Os grupos de vizinhança são também importantes, como no caso da circulação da imagem peregrina de Maria entre as casas, junto da qual também circulam informações, como sobre a realização de excursões. Assim, apesar da importância chave da RCC, os contatos também são realizados por outros meios. Inclusive, o contato 
desses peregrinos nos Cenáculos muitas vezes limita-se ao seu grupo de peregrinos. Visualmente era fácil identificá-los durante os cenáculos, pois eles geralmente estavam juntos, circulando em pequenos grupos pela montanha, ou sentados compartilhando a comida levada, ou na fila da barraca de produtos religiosos. Ou seja, seus contatos, mesmo fora da paróquia, em geral eram estabelecidos com pessoas pertencentes a sua rede de relações paroquiais e de vizinhança. Nos casos mencionados das excursões de Itu e São Paulo isso era perceptível, a maioria dos integrantes não conversava ou estabelecia contato com membros de outras excursões, mas permaneciam em seus grupos. A maioria do público das aparições era constituída por esses "grupos” de peregrinos.

Entretanto, apenas as relações carismáticas de vizinhança não explicam o grande público presente nos Cenáculos de aparições marianas na atualidade, considerando, principalmente, a fluidez destes eventos, que, em muitos casos, não possuem local e data prefixados para a sua realização, acontecendo quando e onde estiver o vidente. Para isso devemos compreender outra dimensão dos Cenáculos e de suas peregrinações, que não é explicada pelas relações religiosas paroquiais, mas por relações religiosas mais extensas, que se configuram em redes.

A explicação para isso adveio da observação dos contatos estabelecidos por alguns peregrinos, que denominamos “elos" - pois servem como ponto de ligação entre uma rede que articula as aparições, que possui características desterritorializadas, e grupos paroquiais, que constituem a "massa” dos peregrinos. Para a articulação desta rede de manifestações marianas é fundamental a contactação dos elos, pois é por meio deles que as peregrinações são organizadas. Como a característica massiva das manifestações marianas na atualidade já foi destacada, podemos afirmar que o sucesso dos eventos depende da capacidade dos organizadores em articular essa rede, sendo que, quanto mais extensa esta articulação - ou seja, quanto mais elos contactados - maiores as possibilidades de sucesso.

Nesse sentido, as peregrinações contemporâneas ganham novas características. Apesar das relações religiosas locais e paroquiais serem importantes para a organização das excursões, as redes mais extensas e desterritorializadas são também necessárias para o sucesso dos fenômenos, como analisaremos a seguir.

Além disso, as relações paroquiais e de vizinhança, característica das romarias tradicionais, não explicam a circulação das pessoas por entre esses fenômenos 
e a circulação das próprias manifestações. Ou seja, os videntes peregrinam, levando o fenômeno consigo, e há peregrinos que circulam e se informam sobre fenômenos do mesmo tipo - não possuindo o perfil do romeiro, que realiza a romaria uma vez ao ano para cumprir a promessa a seu santo de devoção. Trata-se, pois, de uma dupla circulação: de pessoas para as manifestações e das manifestações.

Consideramos, pois, que as peregrinações para as aparições marianas possuem diferenças em relação às romarias, tanto no perfil de parte dos peregrinos como nas relações que possibilitam a movimentação - que são mais complexas do que na Romaria, não se restringindo às pessoas, mas se estendendo às manifestações e informações.

Assim, uma nova caracterização do peregrino e da peregrinação deve ser realizada no contexto atual das manifestações marianas. Para isso nos reportamos a Hervieu-Léger (1999), autora que desenvolve uma nova caracterização para a figura do peregrino na contemporaneidade.

E) A Peregrinação: entre o "novo" e o "antigo"

A figura emblemática da modernidade religiosa, segundo Hervieu-Léger (1999), é o peregrino. Segundo ela, duas características centrais da religiosidade contemporânea são: a mobilidade e as experiências pessoais, sendo que a adesão fixa a uma denominação religiosa é considerada cada vez mais rara. Assim, a autora constrói uma "nova” figura do peregrino - que possui características distintas do peregrino "tradicional” - sendo a "mobilidade, construída a partir de experiências pessoais" marcante nesta nova figura e emblemática da religiosidade contemporânea. O novo peregrino circula em busca de experiências religiosas marcadas pela intensidade emocional, sendo que esta circulação muitas vezes não obedece a fronteiras doutrinárias ou adesões fixas a uma denominação religiosa.

Vale a pena detalhar um pouco mais a figura do peregrino para HervieuLéger, que se delineia a partir de seu debate sobre a religiosidade contemporânea, chamada pela autora de "modernidade religiosa”. A teoria explicativa de Hervieu-Léger sobre a modernidade religiosa está embasada em dois pilares: a autonomia do individuo e a perda de poder e de controle da Instituição/Igreja - e, consequentemente da Tradição -, sendo que esses dois pilares estão profundamente relacionados. 
O ponto de partida de sua análise é o processo de secularização da sociedade francesa, concebida pela autora como um processo de mudança na religião contrapondo-se às análises mais correntes que consideram a secularização como a diminuição da presença da dimensão religiosa na sociedade moderna. Nesse sentido, o religioso ganharia novas formas de presença e inserção na sociedade, que são predominantemente marcadas por duas características interligadas: a perda de poder da instituição religiosa, das grandes religiões - como o catolicismo e o protestantismo, em que a Tradição ocupa um lugar central - e a autonomia do individuo em relação a suas escolhas religiosas.

Trata-se, pois, de um processo chamado de “desregulação institucional”, em que ocorre a diminuição da prática religiosa ligada às instituições, como a presente nas religiões "tradicionais” - protestantismo e catolicismo - e o aumento da participação nos movimentos religiosos “alternativos”, também chamados de novos movimentos religiosos - NMRs - que são pouco institucionalizados.

Nesse sentido, a autora explica o fenômeno de "reavivamento religioso", do qual os movimentos emocionais, como a RCC, são exemplos importantes, a partir das mudanças ocorridas no religioso no contexto da modernidade, em que os indivíduos, ao fazerem suas escolhas religiosas, afastam-se das religiões tradicionais. Antes a participação religiosa era predominantemente ligada à tradição, ela era herdada pelos indivíduos. Já atualmente a validação religiosa, em grande parte dos casos, está relacionada à escolha individual, “o indivíduo passa a deter e a exercer um poder de escolha em detrimento da aceitação naturalizada de parâmetros religiosos e culturais socialmente herdados.” Ou seja, as instituições ligadas à tradição perdem importância diante da centralidade atribuída à escolha do indivíduo. A desregulação institucional está, pois, relacionada principalmente ao processo de individualização que marca a modernidade religiosa.

Hervieu-Léger acrescenta que, com o aumento no seu poder de escolha, o indivíduo detém a possibilidade de transgredir antigos dogmas, de desobedecer à ortodoxia, especialmente no que se refere à unidade doutrinária. Assim, os indivíduos têm "liberdade de bricolar", ou seja, de escolher, de montar seu próprio sistema de crenças diante de uma série de ofertas. Os sujeitos ajustam suas crenças aos dados de sua própria experiência. Não há mais a fidelidade doutrinária a uma instituição religiosa, no caso o catolicismo ou o protestantismo, o universo religiosamente integrado da 
tradição - central nestas religiões segundo a autora - não faz mais sentido para os homens que vivem na modernidade.

Nesse sentido, as referências e signos cristãos permanecem no interior da “cultura moderna”, porém “as tradições religiosas do passado são tratadas como caixas de ferramentas simbólicas, nas quais os homens escolhem livremente, sem que isso signifique necessariamente que se reconheçam naquela visão integrada do mundo e da relação do homem com este mundo que se inscreva historicamente na linguagem daquelas tradições” (1999:41).

Esse processo de secularização na sociedade francesa é um processo de mutação na forma do ser e do agir religioso, em que a há um deslocamento do religioso das grandes Igrejas para o indivíduo, causando uma disjunção entre crença e pertencimento. Segundo a autora, as pessoas continuam crentes, se autodenominam religiosas, porém não pertencem a uma instituição religiosa, ou seja, os sujeitos continuam a acreditar em elementos pertencentes ao sistema de crenças das religiões “tradicionais”, porém, devido a sua subjetividade individual, não seguem ao pé da letra a doutrina das instituições, por isso, na concepção da autora, não “pertencem” à religião, embora sejam crentes, ou seja, a dimensão religiosa não está ausente em suas vidas.

Dessa maneira, há o suposto de que crença e pertencimento andavam sempre juntos na sociedade francesa, crer era pertencer. A figura típica desta religiosidade era o praticante regular, que cumpria com as obrigações religiosas participava da missa, recebia os sacramentos. Por isso a disjunção entre ambos é uma novidade neste contexto, segundo a autora, sendo hoje possível "crer sem pertencer". Uma nova figura de homem religioso surge, então, cujo protótipo é o peregrino, que não age de acordo com a doutrina estabelecida por uma instituição, mas apenas segue suas crenças.

Assim, à frente dessa mudança no religioso está o indivíduo, que não possui um enquadramento institucional fechado, que foge da "religião petrificada das igrejas”, cujo direito à subjetividade individual, mesmo em questões de religião, é central.

Nesse ponto devemos colocar um primeiro questionamento sobre a aplicação desta teoria no caso das aparições marianas no Brasil. Será que esta disjunção pode também ser pensada para o contexto brasileiro, ou melhor, a pergunta seria se a disjunção entre crer e pertencer é uma novidade no Brasil, parece-me que ela sempre ocorreu, embora por motivos bastante distintos daqueles relacionados à modernidade 
religiosa, em que o indivíduo e suas liberdades de escolha e subjetividade ocupam lugar central.

Importa destacar que essa concepção de Hervieu-Léger está inscrita em uma corrente teórica desenvolvida pela sociologia da religião na França, que, desde seu início, considera o pertencimento religioso como a realização das práticas rituais oficialmente estabelecidas pela Igreja, sendo que somente são considerados fiéis aqueles que têm uma regularidade na prática dos sacramentos - no caso do catolicismo. Trata-se de um modo de fazer sociologia em que os aspectos quantitativos são considerados centrais $^{13}$. O pertencimento religioso é medido pelo número de pessoas que recebem os sacramentos em uma paróquia, ou pelo número de vezes por mês que as pessoas freqüentam a missa. O número de sacramentos - batismos, casamentos, comunhões realizados por cada paróquia são contabilizados. Dessa forma, quando a autora menciona a diminuição do pertencimento religioso está fazendo referência à diminuição no número de praticantes regulares, de pessoas que recebem os sacramentos e que seguem a doutrina católica. Assim, nesta corrente teórica pertencimento religioso, doutrina e práticas oficiais caminham juntos, na tradição francesa "ser religioso" é pertencer e seguir os dogmas e práticas de uma instituição/Igreja.

Neste contexto a disjunção entre crença e pertencimento aparece como uma novidade para Hervieu-Léger. Ou seja, devemos levar em conta, então, que esta característica da religiosidade é uma novidade no contexto francês.

Entretanto, devemos mencionar algumas especificidades do catolicismo no Brasil. Em nosso país o ser religioso esteve historicamente relacionado com o ser católico, sendo que, segundo Giumbelli, não existia uma nitidez neste "ser religioso". Em suas palavras "a fórmula que talvez tenha captado melhor essa falta de nitidez do religioso é: ser brasileiro é ser católico” (2007:150). Ou seja, a relação entre catolicismo e sociedade sempre foi muito próxima no Brasil, a ponto de se misturarem. O ser religioso estava fortemente associado à tradição, à herança religiosa. O brasileiro já nascia católico, e sua vida era marcada pelo recebimento de alguns sacramentos especialmente o batismo, o matrimônio e a extrema unção. Já no que se refere à presença na missa e ao sacramento da hóstia, importantes para a caracterização dos “praticantes” na França, este era bastante esporádico no Brasil.

\footnotetext{
${ }^{13}$ Um de seus iniciadores realizou um mapa do pertencimento religioso na França na década de sessenta, em que contabilizou o número de práticas oficiais do catolicismo em todas as paróquias do país, levando em consideração principalmente o número de paroquianos e o número de sacramentos oferecidos por cada uma das paróquias.
} 
O catolicismo popular desenvolvido no Brasil é marcado por esta disjunção entre crer e pertencer, nos termos de Hervieu-Léger, sendo uma religiosidade caracterizada por crenças e práticas realizadas pelos leigos, com a rara presença da Instituição e de seus sacerdotes, na qual a freqüência à missa e o recebimento dos sacramentos não era comum. Nesse sentido, o próprio romeiro tradicional representa a figura do "crente", do devoto leigo que realiza uma promessa para "seu" santo e a cumpre por meio da peregrinação ao Santuário, sem que esta abranja os rituais e os sacramentos estabelecidos pela doutrina católica.

Dessa forma, o romeiro, como o peregrino, “crê sem pertencer”, pois não segue os dogmas católicos. A diferença entre eles - o peregrino de Hervieu-Léger e o romeiro do catolicismo popular brasileiro - está na forma de se exercer a religiosidade. O peregrino representa o indivíduo autônomo e livre para realizar suas escolhas religiosas. Já o romeiro representa o sujeito embrenhado em suas relações religiosas locais, de vizinhança e de parentesco, aquele que herda uma religiosidade tradicional.

Essa polaridade não nos é produtiva, pois os participantes das aparições marianas contemporâneas não se assemelham exclusivamente a nenhum destes dois “tipos”. Como demonstramos neste primeiro item, o "nosso" peregrino está inserido em relações religiosas locais - paroquiais, de vizinhança e parentesco - que são fundamentais para a realização das peregrinações, demonstrando que as relações de tipo tradicional, bem como a Instituição Católica, permanecem importantes nesses fenômenos.

Entretanto, os peregrinos, especialmente os “elos”, não possuem relações religiosas exclusivamente tradicionais, estando inseridos em uma rede de relações mais ampla e com características distintas da religiosidade tradicional. Assim, apesar das especificidades do catolicismo no Brasil, algumas características da "modernidade religiosa”, nos termos descritos por Hervieu-Léger, podem ser observados no agir religioso contemporâneo no país, especificamente no que se refere às aparições de Nossa Senhora. As características desses fenômenos: a mobilidade dos sujeitos entre manifestações religiosas, a forma de organização dos Cenáculos - em que as redes de contato se mobilizam especificamente para a realização do ritual, se dissolvendo em seguida - marcada pela fluidez e pela ausência de lugares fixos para a realização dos rituais, que se tornam possíveis devido à mobilização de uma rede de contatos que ultrapassa as fronteiras locais, paroquiais, aproximam essas manifestações das características desenvolvidas pela autora sobre a “modernidade religiosa". 
Demonstraremos estas novas características a partir da análise da circulação das manifestações marianas.

\section{2) A circulação das manifestações marianas: Redes}

Neste item nos deteremos na circulação das manifestações marianas, pois, foi a partir dessa circulação que constatamos importantes características de uma rede de manifestações de Nossa Senhora.

Para isso, entretanto, devemos diferenciar três tipos de manifestações de Nossa Senhora presentes nesta rede, pois, durante nosso trabalho de campo, percebemos que ao mencionar as aparições devemos também nos estender às outras manifestações extraordinárias, pois as visões são apenas um dos pontos de confluência desta rede, que está interligada a outros fenômenos de Nossa Senhora aos quais os devotos se reportam, ou seja, esses fenômenos pertencem a uma rede de relações religiosas extensas e diversificadas, que também abarca outros fenômenos considerados milagrosos e que interessam aos devotos.

Assim, podemos separar as manifestações de Nossa Senhora em três tipos: aparições, locuções e milagres. As aparições são os fenômenos em que Maria aparece para pessoas, chamadas de videntes, pois são capazes de ver e ouvir Nossa Senhora. Já no caso das locuções há um confidente, que ouve ou sente uma voz interior, reconhecida como de Maria, mas não vê a figura de Nossa Senhora, apenas a "sente”, sendo por isso chamadas de locuções interiores. Já no caso dos milagres não há um sujeito, um mensageiro, mas uma manifestação de Maria considerada incomum, e que, para os devotos, comprova a presença da Virgem - como, por exemplo, o caso de imagens de Maria que "choram”.

As locuções e os milagres da atualidade são marcados pela ausência de referências geográficas, não sendo atribuída qualquer importância ao local onde eles se iniciaram, sendo a circulação dos eventos a sua característica mais marcante e destacada pelos seus devotos. Já no caso das aparições, embora os videntes também circulem e tenham as visões em diferentes lugares, o local inicial, das primeiras aparições, é uma referência para os devotos, sendo os rituais - Cenáculos - organizados nesta localidade, formando-se, em alguns casos, comunidades de fiéis nas suas proximidades. 
De qualquer maneira, a circulação das manifestações, bem como a sua longa duração, é um aspecto presente em praticamente todos os eventos. Devemos desde já destacar que essas novas configurações possuem relação com as formas de apreensão do espaço e do tempo nestas manifestações, sendo que, ao extrapolarem as referências geográficas fixas - ocorrendo nos locais em que estão os videntes e confidentes - sacralizam estes espaços por curtos períodos de tempo - o tempo de duração e permanência das manifestações nos locais.

\section{A) A circulação das manifestações marianas}

Realizaremos uma breve descrição de alguns desses fenômenos em curso na atualidade para demonstrarmos a sua movimentação. Começaremos destacando dois casos de locuções interiores: Padre Gobbi e Vassula Ryden, um milagre: a imagem de Maria que chora mel, e algumas aparições.

\section{Padre Gobbi}

As locuções do Pe Gobbi são amplamente disseminadas pelo Brasil, sendo mencionado em aparições, em grupos de orações, em conversas com participantes, entre outros. Pe Gobbi é um sacerdote italiano que, segundo eles, recebe diariamente mensagens de Maria. Todas as mensagens recebidas por ele estão publicadas em um livro chamado “Aos sacerdotes, filhos preferidos de Nossa Senhora”, reeditado inúmeras vezes no Brasil. A partir das mensagens e do livro são organizados rituais - os cenáculos marianos - nos quais ocorre a oração do terço e a leitura e reflexão sobre alguma das mensagens.

Os cenáculos marianos do Pe Gobbi tiveram inicio em 1973, a partir da primeira locução da Virgem recebida por ele na capela de Nossa Senhora de Fátima, em Portugal. Ele recebeu então a missão de organizar um movimento de devoção a Virgem, que foi batizado como Movimento Sacerdotal Mariano - MSM. Esse movimento está disseminado pelo mundo todo, possuindo ampla penetração no Brasil.

Os cenáculos são realizados por pequenos grupos de pessoas, podendo ser domésticos, contando com cerca de dez pessoas, ou rituais maiores, realizados em capelas, com a presença de até duzentas pessoas. Os rituais não necessitam de locais 
fixos para sua realização, e sequer da presença do confidente, apenas do livro que contém as mensagens transmitidas pela Virgem.

Pe Gobbi circula por todo o mundo, recebendo mensagens diárias de Nossa Senhora e as leva - a mensagem e a própria Maria - por todos os locais por onde passa. Um dos aspectos constantemente destacado por seus devotos é o número de viagens que já realizou - mais de quinhentas, segundo a última edição do livro, em 2004 - por todo o mundo, havendo edições de seu livro em muitas línguas.

Dessa forma, suas locuções podem ser consideradas como desterritorializadas, pois, o local onde recebeu a primeira mensagem - a capela em Fátima - não possui uma importância especial para os membros do MSM, sendo que eles não se deslocam - não peregrinam - para esses locais. É, pois, o confidente que se desloca, sendo que, ao menos uma vez ao ano vem ao Brasil, para realizar palestras. Para estas palestras são organizadas Romarias. Assim, ocorre a peregrinação de fiéis para o ritual em que o mensageiro entra em contato com a Virgem, sendo que o confidente também se deslocou - de uma distância bem maior, inclusive - para o evento. Existe, pois, uma dupla mobilidade relacionada aos cenáculos marianos do Pe Gobbi.

\section{Vassula Ryden}

Vassula é uma católica ortodoxa que recebe mensagens de Maria na forma de locução, já tendo visitado várias vezes o Brasil, travando um contato muito estreito com fiéis da Renovação Carismática Católica no país - suas mensagens são constantemente mencionadas nos grupos de oração da RCC. Suas viagens ao país ocorreram a convite de pessoas ligadas ao movimento, sendo que o intuito delas é a realização de palestras, cujo tema são as locuções de Maria: ela divulga as mensagens que a Virgem lhe transmitiu, e realiza interpretações sobre elas em suas palestras.

Como Pe Gobbi, ela circula pelo mundo todo, não havendo uma localidade fixa aonde os fiéis possam visitá-la. É ela que percorre o mundo divulgando as mensagens que recebeu de Maria, sendo, como no caso do Pe Gobbi, realizadas Romarias com destino a suas palestras. 


\section{A imagem que chora mel}

A “virgem do mel” é uma imagem de Nossa Senhora de Fátima vinda de Portugal, que, no ano de 1994, começou a verter mel pelos olhos, como se fossem lágrimas. Atualmente ela tem autorização do bispo de Maringá - onde mora sua proprietária - para circular pelo país, dependendo sempre também da autorização do bispo da localidade a ser visitada. Nesse sentido, não existe um local fixo para as peregrinações, como um santuário, pelo contrário, é a própria imagem que peregrina pelo Brasil.

Trata-se, pois, de uma imagem itinerante ${ }^{14}$, que percorre diferentes localidades pelo país. Para isso existe um grupo de pessoas que a acompanha nas viagens, chamado, justamente, grupo de acompanhantes, composto por mulheres com mais de sessenta anos, algumas aposentadas. Segundo elas, sua única atividade religiosa é acompanhar Nossa Senhora, ou seja, não estão ligadas a nenhum movimento ou grupo da Igreja, e se denominam católicas “de missa”, estando seu circuito religioso relacionado com o circuito da própria imagem.

\section{As aparições marianas}

Não são apenas os confidentes e as imagens que se movimentam, mas também os videntes. Embora o local onde ocorrem as aparições ainda seja uma referência importante nesses fenômenos, sendo realizados Cenáculos e formadas comunidades nas suas proximidades, os videntes também circulam pelo Brasil, tendo as visões onde estiverem, ou seja, levando Maria consigo. Esse aspecto caracteriza vários fenômenos contemporâneos: Jacareí, Piedade das Gerais, Taquari, Mercês, Sumaré, Niterói, e outros.

Assim, neste item pudemos destacar a característica da circulação das manifestações marianas da atualidade. No caso das locuções e milagres notamos que a referência geográfica deixa de existir, sendo os confidentes e eventos que peregrinam pelo mundo, como nos casos demonstrados de Pe Gobbi, de Vassula Ryden e da imagem que chora mel. Nestes casos o local da manifestação deixa de ser importante,

\footnotetext{
${ }^{14}$ Apesar de sua proprietária ser de Maringá, a imagem praticamente não permanece mais na cidade, estando constantemente em circulação pelo Brasil.
} 
sendo o próprio mensageiro a figura central, pois é a partir deles que Nossa Senhora se manifesta - em locução interior, “em seu coração”.

Já no caso das aparições contemporâneas a circulação dos videntes e dos fenômenos também foi observada. Entretanto, apesar das visões ocorrerem nas mais variadas localidades, o local de origem da aparição permanece uma referência importante, sendo constituídos Santuários e/ou realizados rituais nestes locais.

Nesse sentido, as peregrinações para os locais em que ocorreram as primeiras aparições, bem como a constituição de comunidades nos locais das primeiras visões, apontam para o fato de que a referência geográfica ainda possui centralidade nas aparições contemporâneas. Dessa forma, ao contrário das locuções, em que o confidente é central, nas aparições a pessoa que recebe a visão, apesar de importante, está inserida em um conjunto mais amplo de símbolos e crenças que devem ser desvendados e analisados, pois fazem parte da explicação sobre as aparições.

Além disso, para os devotos a peregrinação aos Santuários é importante. O caso de Medjugorge é ilustrativo deste fato, pois vários peregrinos já participaram de rituais realizados no Brasil com a presença de Mirjana - uma das videntes. Porém, apesar disto, consideram a peregrinação a essa vila iugoslava como uma prática religiosa importante, de maior valor do que o contato apenas com a vidente. A análise mais aprofundada dos fenômenos, de seus símbolos e dos sentidos dados a essas manifestações pelos peregrinos, é parte importante de nosso trabalho, que deverá ser desenvolvido em capítulo posterior. Por hora, nos centramos na movimentação dos fenômenos marianos contemporâneos.

Consideramos, pois, que essa movimentação das manifestações de Maria traz novas características para esse fenômeno. Segundo autores que estudaram o tema das aparições, existe um modelo para esses fenômenos que foi instituído a partir das aparições do final do século XIX e início do Século XX, tendo como principais referências as aparições de Maria em Fátima e em Lourdes. Esse modelo possui padrões recorrentes, girando em torno, segundo Steil, das mensagens e dos segredos transmitidos pela Virgem aos videntes, que geralmente são crianças camponesas. As visões ocorrem em lugares ermos, distantes das cidades - uma gruta em Lourdes e uma “Cova” em Fátima.

Esse modelo se repete nas aparições brasileiras contemporâneas: as mensagens e segredos, as crianças videntes, as localidades rurais. Entretanto, importa reter dois aspectos desse modelo: o fato das aparições ocorrerem em um mesmo local - 
que pode tornar-se então um Santuário de peregrinação - e durante um curto período de tempo - no caso de Fátima foram somente sete aparições, e, em Lourdes, dezoito.

Essas características no tempo e no espaço distinguem as aparições do começo do século XX das aparições de Medjugorje, considerada um novo padrão de aparições, instituído a partir da década de 80 do século passado. Segundo Almeida (2003), a aparição de Medjugorje é o fenômeno que rompe com algumas das características recorrentes das aparições marianas. Duas características são destacadas pela autora: o tempo de duração das visões e a desterritorialização destas. Enquanto nas aparições anteriores o número de visões foi bastante restrito, ocorrendo durante um curto espaço de tempo - em Fátima ocorreram sete aparições, durante sete meses possuindo um local fixo para as manifestações - uma gruta em Lourdes, uma árvore em Fátima -, a aparição de Medjugorje rompe com esse padrão, pois são inúmeras manifestações ocorridas diariamente durante mais de duas décadas - as aparições acontecem desde 1981, todas as tardes - e, além disso, as visões ocorrem em qualquer local em que o visionário esteja presente. Para esta autora as aparições perdem a referência geográfica, se desterritorializam.

Apesar de constatarmos a circulação ou peregrinação das aparições marianas a partir da circulação de seus videntes - capazes de ter as visões em qualquer localidade - e de que elas possuem características desterritorializadas, não concordamos com a afirmação de Almeida de que elas percam sua referência geográfica, pelo contrário, consideramos que esse aspecto permanece importante nas aparições da atualidade. Como no caso de Medjugorje, por exemplo, que se tornou um local de peregrinação Mariana mundial - do mesmo vulto de Fátima e Lourdes - apesar da mobilidade das visões ${ }^{15}$.

Assim, consideramos que a dimensão desterritorializada destes fenômenos está relacionada à sua movimentação através de uma rede de relações bastante extensa não presente apenas no Brasil, mas interligada a outros países e continentes - que possui conexões que não estão presas a um território. As relações entre os membros e grupos dessa rede são estabelecidas a partir de outros meios, que não prescindem da

\footnotetext{
${ }^{15}$ As peregrinações para Medjugorje foram analisadas por Elisabeth Claverie (2003), que em sua obra "Les guerres de la Vierge" demonstra como a vila Bósnia se torna um dos maiores santuários marianos da atualidade. Ou seja, de acordo com a análise da autora, notamos que o local de origem da aparição permanece importante, sendo destino de peregrinos do mundo todo. Analisaremos a importância dos Santuários em capitulo posterior, no momento nos determos na característica desterritorializada destas manifestações.
} 
proximidade geográfica entre eles. De forma semelhante aos rituais com a presença de mensageiros, organizados por membros desta rede, que atraem peregrinos de diferentes localidades, não importando a distância geográfica.

Podemos considerar que a circulação aproxima as manifestações mais recentes das características da modernidade, em que a superação de barreiras geográficas "venceu as barreiras espaciais em tal grau que por vezes o mundo parece encolher sobre nós” (Harvey, 1989:219). Isso ocorreu devido a vários fatores, especialmente as inovações tecnológicas nos transportes - "que aniquilam o espaço por meio do tempo" e nos meios de comunicação. Nesse sentido, as pessoas envolvidas ou interessadas nos fenômenos circulam, mas também as informações sobre eles - seja na forma de livros e DVDs, seja na forma virtual de páginas na internet. No próximo item mostraremos a importância dos meios de comunicação - especialmente as redes de televisão e a internet - na divulgação das aparições marianas e no estabelecimento dos contatos e conexões entre as manifestações. Nesse sentido, as barreiras espaciais foram superadas, pois os membros e grupos circulam sem levar em consideração distâncias sendo comum, por exemplo, as peregrinações para a Europa, bem como a vinda de manifestações marianas européias ou norte americanas para o País, como nos casos de Pe Gobbi, Vassula e Mirjana - a vidente de Medjugorje.

A mobilização e a circulação das manifestações e dos peregrinos dependem, entretanto, de articulações estabelecidas em rede, que mobilizam e conectam membros, grupos e manifestações. Importa destacar que não se trata apenas de circulação simples, mas também de contato e conexão entre confidentes, videntes e pessoas próximas a eles - como os grupos que acompanham imagens milagrosas. Os videntes e confidentes participam uns dos rituais dos outros, e às vezes videntes de localidades diferentes se unem para terem visões. Existem vários exemplos disso, como no caso do vidente Marcos Tadeu, que conhecia Mirna - vidente de Muriaé - Nilda vidente de Goiás -, Ricardo - vidente de Niterói -, Pe Gobbi, Vassula Ryden e Mirian acompanhante da Virgem do mel._Devemos, pois, no próximo item compreender a configuração dessa rede, suas articulações e contatos.

\section{B) As conexões entre as manifestações marianas}

Neste item deveremos analisar as conexões e as articulações estabelecidas entre as manifestações marianas, por meio de seus videntes e confidentes, mas também 
dos grupos de apoio de cada fenômeno. A circulação das aparições marianas ocorre a partir das articulações estabelecidas pelos membros dessa rede, ou seja, ela não ocorre de forma aleatória, mas a partir dos contatos estabelecidos entre os membros de cada manifestação. Além disso, devemos destacar a centralidade dos carismáticos na organização destas articulações, assumindo funções importantes na movimentação das manifestações marianas.

Autores que analisaram as aparições marianas ocorridas recentemente no Brasil constataram o contato entre "mensageiros" de Maria. O caso estudado por Cecília Mariz (2003), sobre o vidente Ricardo, de Niterói, é um deles. Segundo a autora, Ricardo Já havia estado em contato com Marcos Tadeu - Jacareí - Nilda - Anápolis -, Mirna - Muriaé -, Raimundo Lopez - confidente de Belo Horizonte - Maria do Carmo e Lázaro - videntes de Pedralva, em Minas Gerais. Marcelo Camurça (2003), ao estudar as aparições de Mercês, em Minas Gerais, também se refere ao contato da vidente Maria da Penha, com outros mensageiros marianos, como Marilda - de Piedade das Gerais - e Marcos Tadeu - de Jacareí.

Além disso, em nosso trabalho de campo pudemos observar várias fotografias e filmagens - as aparições são comumente fotografadas e filmadas pelos devotos - nas quais estavam presentes mais de um vidente e/ou confidente participando de um mesmo ritual. Em uma delas estava Mirna - de Muriaé - ao lado de Mirjana - a vidente de Medjugorje. Em outra estavam três videntes em um cenáculo em Piedade das Gerais: Marilda - a vidente local -, Marcos Tadeu - de Jacareí - e Maria da Penha - de Mercês.

A partir da constatação da existência de contatos entre membros das manifestações marianas, principalmente entre videntes e grupos de apoio, devemos compreender como são estabelecidas as conexões, pois os autores em questão apenas nos dão pistas sobre contatos estabelecidos entre membros, especialmente videntes e confidentes, como demonstrado nos exemplos anteriores, mas não explicam como os contatos e conexões ocorrem e são estabelecidos. Para isso partiremos dos dados levantados em nosso trabalho de campo.

Começaremos por um grupo de peregrinos da cidade de São José dos Campos, que costumava participar das aparições na cidade de Muriaé. Desse grupo faziam parte Célia e Olga, ambas carismáticas, líderes de grupos de oração e participantes de retiros - de conversão, de libertação - realizadoras dos terços da libertação, da misericórdia e de Nossa Senhora desatadora dos nós. Na verdade, por seus 
depoimentos, poderíamos considerá-las como perfeitamente enquadradas na RCC, sendo que maioria de suas práticas estava vinculada a esse movimento, ou então eram divulgadas pela RCC - como no caso dos terços mencionados.

Ambas conheciam vários santuários de aparição, não apenas no Brasil como também no exterior - Fátima, Lourdes, Medjugorje e Garabandal - e, além da aparição de Muriaé, com a qual mantinham uma regularidade na freqüência, peregrinavam constantemente para outros santuários, mas sem freqüência regular ${ }^{16}$. Conheciam pessoalmente vários videntes - Marcos Tadeu, de Jacareí, Marilda, de Piedade; Ricardo, de Niterói; entre outros, e nos mostraram que eles também circulavam entre aparições, como peregrinos. Exemplo disso foi uma excursão realizada por Célia, da RCC, para a aparição de Muriaé, na qual Marcos, vidente de Jacareí, estava presente, demonstrando seu interesse e contato com outros videntes. Ou seja, era uma excursão para uma aparição Mariana, organizada por uma fiel carismática, em que o vidente de uma outra aparição - Jacareí - estava participando.

Além disso, mantinham contato estreito com Raimundo Lopez, um empresário de Belo Horizonte que recebia locuções de Nossa Senhora, e ia a São José dos Campos com certa regularidade, para ministrar palestras aos carismáticos, bem como elas freqüentavam a capital mineira para participar de rituais organizados por ele. Também participavam de palestras proferidas por confidentes, entre as quais destacavam Pe Gobbi e Vassula Ryden.

Essa rede de relações observada a partir de Célia e Olga, em São José dos Campos, foi reconstituída a partir de outro ponto de partida, pela entrevista que realizamos com Miriam. Ela é moradora de Maringá, no interior do Paraná, e não se considera carismática, mas acompanha uma imagem de Nossa Senhora que verte mel pelos olhos e é considerada milagrosa, já tendo circulado por todo o país.

É interessante notar que Mirian não freqüenta os Cenáculos de aparição Mariana, sendo que sua única peregrinação é acompanhar a “sua Nossa Senhora”, mas, apesar disso, conhece, ou ao menos já “ouviu falar” de muitos videntes por todo o país.praticamente os mesmos mencionados por Célia e Olga - bem como o Pe Gobbi, Vassula Ryden e Raimundo Lopes. Referiu-se a muitos deles durante a entrevista como Mirna, de Muriaé, Marcos Tadeu, de Jacareí; Ricardo, de Niterói, entre vários

\footnotetext{
${ }^{16}$ Vale a pena mencionar que ambas possuíam uma enorme quantidade de material sobre inúmeras aparições - brasileiras ou não. Quando fui entrevistá-las, na casa de cada uma delas, fiquei realmente perdida entre livros, jornais, revistas, fitas cassete, medalhas, terços, referentes as mais variadas aparições.
} 
outros - e, mesmo não participando dos eventos de aparições, conhece a história de muitas delas com detalhes, bem como a seus videntes e/ou organizadores. Isso ocorre devido à presença deles nos locais por onde a imagem que chora mel peregrina, pois, quando ocorre a realização de um cenáculo com a presença da Imagem do Mel em alguma localidade, vários videntes e membros de grupos de apoio das cidades próximas são contactados, e, então, peregrinam para participarem do ritual.

Essas imbricações correspondiam aos “pontos de confluência” dessa rede, aos pontos de contato entre os membros de diferentes origens e grupos, que são estabelecidos nos rituais de manifestações marianas. Isso se tornou claro durante a visita de uma imagem peregrina de Nossa Senhora, que verte mel pelos olhos, à cidade de São José dos Campos.

A manifestação da Virgem do Mel, ainda que móvel, pode ser considerada um dos pontos de confluência de uma rede de relações estabelecidas entre “mensageiros” de Nossa Senhora e seus grupos de apoio - ou grupos de acompanhantes - e membros do movimento carismático. As informações e as relações estabelecidas por Miriam não diferiam das informações e relações de Célia e Olga, pelo contrário, elas se intercruzavam, apesar de partirem de pessoas de origem geográfica distante, mostrando que essa rede não estava restrita a relações de proximidade geográfica - embora elas também estivessem presentes no dia a dia de suas práticas religiosas.

Como a manifestação em questão não possui uma referência geográfica fixa, estando em constante circulação, os locais para onde ela peregrinava tornavam-se, temporariamente, pontos de confluência dessa rede. Importa destacar que os locais de realização de seus rituais eram as comunidades carismáticas ou os Santuários de Aparições, como demonstraremos a seguir. A partir da observação da movimentação dessa imagem, bem como dos peregrinos, pudemos perceber com mais detalhes a configuração dessa rede.

Outro aspecto importante é que os membros dessa rede também participavam de práticas rituais estabelecidas em suas paróquias, assumindo, em muitos casos, papéis de destaque ou liderança localmente, além de manterem contato com pessoas ou grupos extra paroquiais. Os exemplos de Célia e Olga são emblemáticos, ambas são lideres carismáticas em suas paróquias, sendo que Olga foi durante muito tempo catequista e ambas participam regularmente de atividades nas proximidades, como terços e pequenas procissões, sendo, geralmente a partir dessas redes que organizam peregrinações. Entretanto, elas circulam muito, possuindo contato com 
outras lideranças, outros organizadores de peregrinações e com vários videntes de Nossa Senhora. O comportamento delas nas peregrinações difere dos peregrinos que não estão inseridos nessa rede, elas conversam com outros organizadores, com os videntes, ou seja, não ficam limitadas ao grupo de peregrinos de sua paróquia de origem, suas relações e contatos são mais amplos e se sobrepõem às relações estabelecidas nas paróquias. Ou seja, elas representam os elos da rede de manifestações de Nossa Senhora.

\section{A Virgem do mel na Comunidade Magnificat}

Participamos da visita da imagem de Nossa Senhora que chora mel na Comunidade Magnificat, na cidade de São José dos Campos, interior de São Paulo, sendo que, a partir das observações realizadas neste ritual pudemos constatar a importância central dos carismáticos para a mobilização das manifestações marianas, principalmente a partir de suas comunidades.

Nesse episódio constatamos a presença de diferentes “mensageiros” ou grupos nesse evento. Podemos mencionar quatro deles:

1) Os fiéis carismáticos de São José dos Campos - a comunidade Magnificat, onde estava sendo realizada a visita, é carismática ${ }^{17}$.

2) Os coordenadores do MSM em São José dos Campos.

3) O vidente Marcos e o grupo de apoio de Jacareí.

4) O grupo de acompanhantes da imagem.

O grupo de acompanhantes da imagem, apesar de não participar de outras manifestações extraordinárias da Virgem, conhece pessoalmente vários videntes e confidentes - como Marcos, Mirna, Pe Gobbi, Ricardo e Diogo - devido à presença deles nos locais percorridos pela Virgem do Mel. Ou seja, os confidentes e videntes de diferentes manifestações no Brasil vão ver a imagem da Virgem do mel, quando ela se encontra relativamente próxima de suas cidades de origem. O vidente Marcos, de Jacareí, por exemplo, estava presente na comunidade Magnificat neste dia. Também o vidente Diogo, de Vinhedo, era um visitante esperado. Esse episódio demonstra,

\footnotetext{
${ }^{17}$ A comunidade Magnificat está localizada na periferia urbana de São José dos Campos. Foi organizada pelos carismáticos, tendo como liderança Irmã Alice, que reside no local, bem como outros fiéis do movimento. Possui um amplo espaço, composto pela capela, pela residência dos celibatários, pela cantina e refeitório e por uma loja de artigos religiosos.
} 
novamente, que os locais pelos quais a Virgem do Mel peregrina tornam-se, temporariamente, pontos de confluência da rede de manifestações marianas, no qual membros de diversos fenômenos estabelecem contato e conexão.

Outro aspecto importante é que o interesse e a organização da visita partiu dos carismáticos da comunidade Magnificat. Não foi a primeira vez que a comunidade organizou a estadia da imagem, sendo que, em todas as vezes, a iniciativa e o financiamento da peregrinação correram por conta da comunidade.

Segundo o grupo que acompanha a imagem, a grande maioria dos locais que a imagem percorre são comunidades de carismáticos ou Santuários Marianos, sendo que a iniciativa da visita parte deles - carismáticos ou grupos de apoio. A permanência em alguma Igreja ou em locais administrados pelos representantes oficiais da Igreja é extremamente rara. Inclusive, essa peregrinação pode ocorrer de maneira "clandestina”. Cito um exemplo: segundo relatos, da vez anterior em que a imagem esteve em São José dos Campos, os carismáticos não haviam conseguido autorização do bispo para trazê-la, e, então, o fizeram "escondido". Ou seja, a imagem visitou a cidade e permaneceu na Comunidade Magnificat por um final de semana, onde foi visitada por vários peregrinos, mas sem a autorização do bispo e contrariando suas determinações.

A forma como a imagem foi recebida em São José dos Campos, segundo os acompanhantes, comumente ocorre: a imagem é recebida em uma comunidade carismática, ou por um grupo de carismáticos, que se responsabiliza pelos custos da viagem, bem como pela sua recepção, ou seja, os rituais que ocorrerão durante o tempo de permanência da imagem são organizados por eles.

Além disso, os visitantes da imagem também mantêm um perfil semelhante, sendo constituído majoritariamente pelos moradores das proximidades e os membros do movimento. Porém, a imagem milagrosa também atrai videntes e confidentes por onde passa, sendo assim que o grupo de acompanhantes estabeleceu contato com muitos deles.

Dessa forma, a peregrinação da imagem de Maria aponta para a centralidade dos carismáticos nesta rede, sendo responsáveis pela organização da maioria de suas viagens pelo país, desde a contactação dos mensageiros, até a divulgação e financiamento dos eventos. Essa rede é bastante eficiente e mantém intenso contato e troca de informações entre si. Exemplo disso é o fato da imagem do mel circular constantemente entre comunidades carismáticas, sendo poucas as ocasiões em que permanece em Maringá. 
Porém, essa rede não é composta apenas pelos carismáticos, estendendo-se aos "mensageiros" de Nossa Senhora e aos membros dos grupos de apoio das manifestações. Como citamos anteriormente, membros das aparições também participam e estabelecem contatos nos cenáculos da Virgem do Mel. Inclusive, a estadia e permanência da Virgem do Mel em Santuários de Aparição são também comuns, o que demonstra a conexão entre seus membros - grupo de acompanhantes da imagem e grupos de apoio das aparições.

Assim, nessa rede estão inseridas outras lideranças importantes, que não se consideram carismáticas, sendo ligadas diretamente a um fenômeno específico, geralmente participando de seu grupo de organizadores ou sendo o próprio vidente/confidente. Os casos de Miriam e Marcos Tadeu são demonstrativos disso. Mirian acompanha a imagem da Virgem do Mel, mas não é carismática - apesar de circular entre comunidades de carismáticos - e tem contato com vários videntes, apesar de não participar de aparições ou locuções - exceto quando "leva” a "sua” imagem para algum Santuário de Aparição, mas por iniciativa e organização do grupo de apoio do local a ser visitado. Já Marcos Tadeu e seu grupo de apoio, em sua Paróquia, participam apenas dos rituais organizados por eles próprios, não são carismáticos, porém, mantém uma rede de circulação e informações sobre outras manifestações de Nossa Senhora, muitas vezes por meio e junto com os carismáticos, como no caso da excursão para Muriaé organizada pelos carismáticos de São José dos Campos, do qual Marcos e outros de seu grupo de apoio participaram.

Dessa maneira, a circulação das manifestações se dá por meio de redes que não envolvem a Igreja “oficial”, mas sim lideranças e membros de destaque do movimento carismático e das manifestações marianas, tendo como pontos de confluência as comunidades da RCC e os Santuários das aparições, e que coloca em contato e conexão carismáticos e mensageiros de Nossa Senhora, bem como os mensageiros entre si.

Os contatos e conexões entre carismáticos e mensageiros podem ser observados também a partir de dados apresentados em trabalhos de outros autores sobre as aparições marianas, embora não tenha sido analisada por eles. Como na aparição pesquisada por Cecília Mariz em seu artigo sobre as visões de Ricardo, em Niterói. Segundo ela “apesar de mais ligado ao evento em Niterói e ao vidente Ricardo, o grupo se interessa e se informa sobre diversas aparições que estão ocorrendo. (2003:264). Segundo Mariz, o grupo de Niterói possui conhecimento e contato com outros videntes, 
entre os quais menciona Marcos, de Jacareí, sobre o qual possuía uma fita de vídeo; Mirna, de Muriaé, também possui um vídeo sobre a aparição; Raimundo Lopez, de Belo Horizonte, possui um livro; e Nilda, de Anápolis, possui um livro com as mensagens recebidas. Além das informações, possuía relatos de contatos entre Ricardo e esses outros videntes, pela peregrinação de Ricardo a outros Santuários ou vice e versa.

Assim, o interesse sobre manifestações extraordinárias da Virgem está presente entre os devotos de aparições, seja em Jacareí, São José dos Campos ou Niterói, constituindo uma rede de interesse e de circulação entre aparições marianas, no qual não apenas os devotos informam-se e circulam entre vários eventos desse tipo, mas também os videntes e confidentes.

O exemplo mais contundente da conexão entre os “mensageiros” de Nossa Senhora no Brasil foi um encontro sigiloso organizado pelo Pe Gobbi no país, em uma comunidade carismática de destaque, que contou com a presença de aproximadamente cem mensageiros marianos. Durante esse evento, cada mensageiro recebeu uma imagem da Virgem - correspondente à denominação da qual recebe as mensagens. Novamente podemos observar que esta rede tem como "pontos de confluência” as comunidades carismáticas. Entretanto, as articulações estabelecidas nas comunidades ultrapassam os membros da RCC, partindo, em alguns casos, de lideranças não pertencentes ao movimento, embora conectadas a ele por meio da rede.

Além disso, outro aspecto importante da circulação de eventos e de pessoas por essa rede diz respeito à divulgação e ao financiamento destas manifestações. Sob esse aspecto, não podemos deixar de destacar que a divulgação das manifestações, bem como o financiamento da circulação dos videntes, conta com a contribuição dos carismáticos.

Destacamos, inclusive, que conexões são observadas também nas crenças carismáticas, e não apenas nas relações e contatos estabelecidos. Como ilustração às crenças carismáticas nas aparições marianas, a centralidade do chamado "ciclo de Maria”, idéia estabelecida pelo Pe Jonas Abib, um dos fundadores e líder nacional da RCC, segundo a qual existe um ciclo de aparições da Virgem, iniciado em Fátima (1917), continuado em Garabandal (1960) e que deve se encerrar em Medjugorge (1981). Segundo ele, em Fátima as aparições aconteciam pela manhã, em Garabandal no meio do dia e em Medjugorge às 17h40min. O horário das aparições indicaria o fim do tempo dado por Deus para a humanidade, a proximidade do Juízo Final. Essa concepção 
é propagada também em livros e impressos do movimento, além da rede carismática de rádio e televisão “Canção Nova”, e reproduzida por muitos fiéis, durante pregações em rituais, mas também em conversas informais, quando o assunto são as aparições de Maria $^{18}$. A circulação de símbolos e crenças também é foco de nosso trabalho, embora não caiba nas pretensões deste capítulo.

\section{A Divulgação e o Financiamento}

A divulgação das manifestações marianas ocorre pela utilização da estrutura do movimento, principalmente pelos rituais "de base" da RCC - os grupos de oração, mas também por meio de jornais impressos, de redes de rádio e televisão pertencentes ou ligados a ela.

Na verdade, os meios utilizados para a divulgação de um evento dependem de seu grau de importância. Por exemplo, no caso da vinda de um mensageiro internacional - como no caso de Pe Gobbi, Vassula ou uma das videntes de Medjugorje - a divulgação é mais intensa e ampla, recorrendo-se aos meios de comunicação de massa, como as redes de rádio e televisão católicas e carismáticas, bem como pelos sites da RCC. Inclusive, uma das grandes responsáveis pela divulgação de informações sobre as aparições marianas é a rede de televisão “Canção Nova”, de propriedade da RCC e que tem abrangência nacional - possuindo também um site bastante completo e constantemente atualizado. Um dos responsáveis por essa divulgação é o Pe Jonas Abib, líder nacional do movimento, considerado um de seus pioneiros no Brasil. Ele faz parte da comunidade "Canção Nova" e possui horários de pregação pela TV, muitas delas dedicadas a Nossa Senhora, de quem se afirma profundamente devoto.

Essa rede de televisão é também responsável pela divulgação e organização de peregrinações para Santuários Marianos no exterior, especialmente na Europa. Existem agências de turismo que oferecem seus pacotes religiosos nessa rede, e contam com o apoio dela não apenas na divulgação de seu produto, mas também na organização das excursões e do roteiro, sendo as viagens acompanhadas por alguma liderança da comunidade Canção Nova, sacerdotal ou leiga.

\footnotetext{
${ }^{18}$ Essas três aparições européias são referência constante no discurso carismático. Para os carismáticos, a referência mais importante nos dias de hoje é Medjugorge, onde a Virgem transmite mensalmente uma mensagem. Internacionalmente, também mencionam Garabandal, na Espanha, e Fátima, novamente como o princípio de um ciclo de aparições da Virgem. As conexões estabelecidas nas crenças referentes às aparições serão objeto de outro capítulo.
} 
Já no caso de eventos de menor porte, como a estadia da virgem do mel em alguma comunidade, a divulgação é realizada na diocese, nas cidades vizinhas, por meio de jornais carismáticos de circulação regional e/ou por avisos em rituais, telefonemas entre conhecidos, ou seja, por meio da divulgação “boca a boca”.

A divulgação é central para esses eventos, pois é por meio dela que os elos da rede são contactados, sendo que, a partir do aviso sobre o ritual, não apenas participam deles como organizam Romarias para a manifestação, entre pessoas com as quais mantém relações religiosas em sua paróquia. Assim, para que um evento obtenha sucesso é preciso que seus organizadores o divulguem, contactando e articulando elos da rede para participarem do ritual, bem como para organizarem Romarias entre as pessoas que fazem parte de suas relações paroquiais.

Além da divulgação, a RCC é a responsável pelo financiamento dos eventos, pois a circulação das manifestações marianas, bem como a peregrinação constante a Santuários marianos exige recursos financeiros, que são mobilizados, nos casos de visitas realizadas às comunidades ou grupos do movimento, entre os membros da RCC, especialmente entre os membros de destaque na comunidade: lideranças, palestrantes, entre outros. Como no caso das visitas aos locais de aparição é o grupo de apoio local responsável por angariar fundos para o evento.

Os recursos para a circulação das manifestações, videntes e confidentes são angariados pela mobilização dos membros locais, a partir dos grupos ou comunidades carismáticas. Após o contato com os responsáveis pelas manifestações, realiza-se uma planilha de custos, que é divulgada para solicitar recursos. Essa planilha circula entre membros da comunidade, sendo que cada um colabora com o que pode. Entretanto, a maior parte dos recursos é bancada pelas lideranças e pelos membros de maior poder aquisitivo, que também se responsabilizam em contactar as lideranças estaduais ou nacionais do movimento em busca de recursos, bem como comunidades carismáticas. $\mathrm{O}$ sucesso na obtenção destes recursos depende, em parte, das relações e do prestígio dos membros de cada grupo, sendo que os grupos com maiores contatos e conexões com as lideranças nacionais e/ou com comunidades “ricas” são as que conseguem “trazer” mais eventos.

Sob esse aspecto, a comunidade Magnificat, de São José dos Campos, pode ser considerada "bem relacionada”, pois seus membros de destaque, como Irmã Alice - fundadora da comunidade - possui contatos estreitos com as lideranças 
nacionais e com membros de destaque da comunidade "Canção Nova”, a maior comunidade carismática do país e também uma das mais ricas. O próprio Pe Jonas Abib, líder nacional da RCC e um dos fundadores da "Canção Nova”, é considerado “um amigo pessoal” por irmã Alice. Assim, a Comunidade Magnificat recebe a visita de muitos mensageiros de Nossa Senhora, sendo a imagem da Virgem do Mel apenas uma destas manifestações.

Dessa maneira, a rede é mobilizada para angariar recursos para a circulação dos eventos ${ }^{19}$, trazendo pessoas com o dom da locução para proferir palestras, ou videntes para ter suas visões nas comunidades. O grupo de carismáticos de São José dos Campos já trouxe, além da imagem de Maria que verte mel, os seguintes confidentes: Pe Gobbi, Vassula Ryden, Raimundo Lopez, Mirna, entre outros. Inclusive, foi através da RCC que a vidente Mirjana, de Medjugorje, uma das aparições mais conhecidas atualmente, visitou o Brasil, na comunidade “Canção Nova”.

A extensão da rede mobilizada para o financiamento, bem como os tipos de divulgação utilizados variam de acordo com a importância e a grandeza do evento. Nos casos das visitas de confidentes internacionais ao país, bem como nas excursões para os Santuários Internacionais, a divulgação ocorre através de sites católicos carismáticos e através das redes católicas de televisão - Canção Nova e Rede Vida além, claro, da divulgação boca a boca, nos rituais do movimento, entre amigos, etc...

Da mesma maneira, as redes mobilizadas para o financiamento dos eventos de maior importância são as mais extensas. Como nos casos mencionados no parágrafo anterior, em que, mesmo quando a iniciativa da visita não parte de membros da hierarquia nacional do movimento, parte de pessoas que possuem contatos e relações com eles, que possam, de alguma maneira, sensibilizá-los a contribuir para a vinda do confidente.

Percebemos que a realização de manifestações marianas em comunidades carismáticas é mais comum do que nos locais de aparição, devido, justamente, a capacidade da RCC em mobilizar um maior número de elos da rede, ou membros mais poderosos - seja no que se refere ao prestígio ou ao poder financeiro. Nesse sentido, não apenas a organização burocrática e hierárquica contribui, mas também as comunidades carismáticas, que possuem autonomia financeira e religiosa, além de alojamentos e

\footnotetext{
${ }^{19}$ Formavam outras redes de classe, com contato com pessoas de maior poder aquisitivo e, assim, com maiores possibilidades de conseguirem recursos.
} 
capelas para realização de rituais, ou seja, toda uma estrutura que facilita o recebimento destes eventos.

Assim, a possibilidade dos grupos de carismáticos e mesmo das comunidades em acessar diretamente membros da hierarquia carismática, ou representantes de comunidades maiores e mais poderosas contribui não apenas para o número de eventos que consegue realizar, mas principalmente para o peso deles. Devemos destacar que, as manifestações mais importantes são alocadas nas comunidades maiores do movimento, entre as quais destacamos a Comunidade "Canção Nova”, em Cachoeira Paulista. Dessa maneira, apesar da estrutura hierárquica, nem sempre os membros seguem essa hierarquia, contactando diretamente membros da coordenação nacional, ou de alguma comunidade carismática de muito destaque. O exemplo de Irmã Alice, representante da comunidade Magnificat, é ilustrativo deste fato, pois, apesar desta comunidade ser pequena, ela realiza rituais importantes, inclusive internacionais, sendo que a proximidade entre Irmão Alice e Pe Jonas Abib, da comunidade Canção Nova, contribui para esse fato.

A importância do evento pode ser observada, pois, a partir das redes que mobiliza - para sua organização, divulgação e financiamento. O caso analisado da Virgem do mel, por exemplo, mobilizou os carismáticos locais - lideranças e não lideranças - e videntes das proximidades. Não foi divulgado e financiado por meio de uma rede muito extensa, tocando membros do município e de municípios vizinhos.

Já o caso do encontro de "mensageiros", promovido pelo Pe Gobbi mobilizou elos de todo o país, uma rede extensa, tendo sido financiado por membros da hierarquia nacional da RCC e do Movimento Sacerdotal Mariano. Interessa destacar que foi um evento sigiloso, e capaz de exemplificar o poder de articulação dessa rede, pois não foi abertamente divulgado, mas que contactou mais de cem videntes e confidentes de Nossa Senhora de todo o Brasil.

\section{3) Redes: territorialização $x$ desterritorialização}

Ao longo deste capítulo demonstramos duas características importantes das manifestações marianas na atualidade. Por um lado, a importância das relações territoriais, que tem como base as paróquias e grupos de vizinhança, na organização das peregrinações. E, por outro lado, uma rede desterritorializada, que se volta para o 
movimento carismático, mas que não se restringe a ele, sendo marcada pela intensa circulação e troca de contatos por meios diferentes da anterior - redes de televisão e rádio, sites na internet, jornais e revistas. Possui, pois, complexidade e extensão maiores, utilizando-se de toda a estrutura do movimento carismático, desde suas redes de rádio e televisão para a divulgação de roteiros turísticos para Santuários Marianos, bem como de seus recursos financeiros para providenciar viagens de videntes a esses Santuários, ou para trazê-los para comunidades carismáticas. As comunidades carismáticas representam os pontos de confluência dessa rede, sendo locais em que várias pessoas de destaque se encontram e estabelecem novos contatos. Entretanto, importa mencionar que são pontos de confluência no momento em que as manifestações marianas estão nelas alocadas e não permanentemente.

As percepções do espaço e do tempo são diferenciadas nas peregrinações para os Cenáculos marianos, não existindo a sacralização de um espaço concreto por um tempo indeterminado, mas pelo contrário, há a fluidez de ambos. Os espaços são temporariamente percebidos como sagrados, durante o tempo pelo qual a manifestação lá permanece. Porém, uma exceção importante deve ser feita para o caso das aparições de Nossa Senhora, em que o local em que ela aparece possui importância para os devotos, estando relacionado a uma grande simbologia referente a estes eventos, que não são novos no âmbito do catolicismo, que serão detalhadamente analisados no terceiro e quarto capítulos.

Pudemos constatar características de desterritorialização nas manifestações marianas, principalmente nas locuções interiores e nos milagres. Neste capítulo analisamos a imagem de Maria que verte mel, que não possui um Santuário ou um local onde peregrinos possam visitá-la. Há também os casos de confidentes de Nossa Senhora, que não a vêem, mas que recebem mensagens interiores, em que não há um local de referência, mas sendo a pessoa o recipiente da divindade, e ocorrendo o evento onde quer que elas estejam, - como no caso de Pe Gobbi e Vassula Ryden, dois dos confidentes mais iminentes da atualidade, que já estiveram no Brasil várias vezes, ministrando palestras, e também de Raimundo Lopez, de Belo Horizonte, mencionados neste capitulo.

Esses exemplos nos mostram, como já havia afirmado estudiosos sobre o tema, que há uma desterritorialização em curso nas manifestações de Maria. Entretanto, mesmo diante dessas novas características, especialmente no caso das aparições - em 
que os videntes também peregrinam, não estando a visão exclusivamente vinculada a um território -, a referência geográfica ainda é importante, o local onde as primeiras manifestações ocorreram ainda é percebido como importante pelos devotos. Embora existam casos de manifestações sem local fixo, e, portanto, sem um Santuário para as peregrinações, sendo principalmente os eventos que circulam, e não os peregrinos, no caso específico das aparições o local da manifestação mantém-se importante.

Isso foi observado em Jacareí, onde está em construção uma Igreja, na montanha em que ocorrem as aparições de Maria, sendo que esse local, durante o segundo domingo de cada mês, dia da aparição, recebe um grande número de ônibus e vans de peregrinos vindos de diversas localidades. Embora Marcos Tadeu também peregrine para outras manifestações marianas e receba as visões em outras localidades, o “seu” Santuário permanece na Montanha em Jacareí, onde sempre está presente durante os segundos domingos de cada mês.

A partir dos dados levantados por Carlos Steil (2003), em Taquari, e por Tânia Mara (2004), em Piedade das Gerais, pudemos reforçar a importância da localidade nas aparições marianas. Nos fenômenos analisados por esses autores, nos locais onde ocorreram as primeiras aparições foram constituídas comunidades de devotos, ou seja, pessoas se deslocaram de suas cidades de origem para irem residir próximo ao local das aparições - esse fato não ocorreu em Jacareí, não houve constituição de uma comunidade religiosa habitando o local. Já nas aparições de Piedade e de Taquari formaram-se vilas religiosas nestas cidades. No caso de Piedade das Gerais, por exemplo, foi constituído o "Vale da Imaculada Conceição”, local onde vários peregrinos fixaram residência, construindo suas casas no sítio onde a vidente Marilda recebe as aparições. Essa é uma evidência importante de que o local onde Nossa Senhora escolheu para aparecer permanece central para os devotos, que são capazes de mudar suas vidas para irem habitar próximo ao lugar escolhido pela Virgem.

Assim, mesmo diante da circulação dos videntes, que na nova configuração dos fenômenos têm as visões de Maria onde eles estiverem, o local de início, o “escolhido” por Maria para aparecer aos homens, permanece importante para seus devotos, que continuam realizando peregrinações a esses locais, e, em alguns casos, transferindo suas habitações para a região.

Nesse sentido, apesar da rede com conexões desterritorializadas, os membros que a integram consideram a peregrinação para os Santuários Marianos, 
especialmente os de repercussão internacional - como Fátima, Lourdes e Medjugorje como uma prática ritual importante. As peregrinações aos Santuários reconhecidos de Nossa Senhora, especialmente da Europa, são consideradas, por esses elos, como fundamental. Vários deles já realizaram essa peregrinação, relatando-a como um momento sublime em suas vidas, inesquecível - contam detalhes do Santuário, dos rituais, das pessoas e reforçam o desejo de voltar a peregrinar. Já entre os que não realizaram a viagem, colocam como “o sonho de suas vidas” a peregrinação aos Santuários europeus, especialmente Fátima e Medjugorje. Assim, a peregrinação, no sentido de ida a um Santuário, que possui uma referência geográfica fixa, permanece importante entre eles.

Além disso, entre os elos da rede pela qual os fenômenos circulavam, muitos deles responsáveis pela recepção de confidentes ou de fenômenos, organizadores de palestras e rituais com a presença de Nossa Senhora - seja como imagem milagrosa, seja "trazida" por seus confidentes e videntes - a importância de se conhecer os locais em que Maria apareceu originalmente era reiterada. Tanto que, além de organizarem os rituais em suas comunidades ou paróquias, peregrinavam para presenciarem eventos do mesmo tipo em outras localidades no país. Ou seja, não apenas a peregrinação para os Santuários reconhecidos é percebida como importante, mas também para locais em que Nossa Senhora “escolheu para aparecer” no Brasil.

Assim, embora as aparições ganhem características desterritorializadas a partir da década de oitenta, especialmente a partir de Medjugorje, com a circulação de seus videntes, a referência geográfica fixa das aparições marianas não perde a sua importância. Pelo contrário, forma-se um novo tipo de rede de organização, divulgação e mesmo financiamento das peregrinações aos Santuários - como pelo financiamento de viagens de videntes e confidentes a Santuários europeus - que reforça a importância da prática de peregrinar. Nesse sentido, a peregrinação à Medjugorje, por exemplo, mesmo com a circulação de seus videntes e com a reprodução das aparições na localidade onde eles estiverem, não diminui a importância de se viajar para essa vila iugoslava. Tanto que, várias dos elos com que tivemos contato conheciam ou pretendiam conhecer a vila, mesmo já conhecendo pessoalmente sua vidente - Mirjana - quando ela esteve no país. Inclusive, essa prática é incentivada pela própria rede, ao colaborar com agências turísticas que organizam as excursões aos Santuários marianos internacionais. 
São, pois, duas dimensões distintas das aparições marianas: por um lado a sua circulação, que ocorre através de uma rede de eventos semelhantes, que possui características transnacionais, não estando vinculada a um território específico. Por outro lado, a importância das referências geográficas fixas, tanto nas relações religiosas paroquiais - fundamentais para a organização de várias peregrinações - quanto na importância atribuída pelos peregrinos ao local em que as aparições se iniciaram.

Além disso, as aparições possuem dimensões que ultrapassam os videntes, e, ao considerá-las desterritorializadas corremos o risco de centrar a análise apenas nos mensageiros, sendo que parte dos sentidos desses eventos está além deles. Sob esse aspecto, para os devotos, conhecer o vidente e presenciar sua visão, é importante, mas não suficiente, é preciso conhecer o lugar que ela "escolheu” para aparecer. Assim, a peregrinação para os lugares escolhidos pela Virgem - e não pelo vidente ou por outros grupos - demonstra que a aparição tem sentidos que ultrapassam a figura do mensageiro, e que devem ser também analisadas.

\section{4) Igreja e Movimentos: a importância da intermediação na} religiosidade contemporânea.

O agir religioso contemporâneo no país, no que se refere às aparições de Nossa Senhora, possui características semelhantes à figura do peregrino desenvolvido por Hervieu-Léger (1999), especificamente sobre a mobilidade dos sujeitos entre manifestações religiosas e a forma de organização dos Cenáculos - em que as redes de contato se mobilizam para a realização do ritual, se dissolvendo em seguida - marcada pela fluidez e pela ausência de lugares fixos, somente possível devido à mobilização de uma rede de contatos que ultrapassa as fronteiras locais, paroquiais.

Entretanto, devemos lembrar a discussão realizada no início do capítulo, na qual demonstramos que para esta autora a figura do peregrino está embasada na autonomia do indivíduo e na perda de poder da instituição. Nossa análise demonstrou que estes dois pilares podem ser questionados nas peregrinações para as aparições marianas contemporâneas.

Por um lado, não consideramos a classificação destes peregrinos como “indivíduos modernos”, nos termos adotados por Hervieu-Léger, como a mais adequada neste tipo de manifestação. Lembramos que a classificação da autora destaca que a 
subjetividade nos fiéis influencia diretamente as suas escolhas religiosas diante das diversas ofertas, opondo-se aos "antigos" participantes de uma religiosidade “tradicional”, herdada, e, portanto, não escolhida. Esse “novo” sujeito religioso parece estar isolado em suas opções de práticas religiosas.

Entretanto, ao entrevistarmos os participantes dos Cenáculos, ao contrário desse "isolamento" característico do indivíduo moderno, notamos a inserção destes praticantes em relações de proximidade e vizinhança, as quais se remetem para explicar sua participação nos rituais. Demonstramos que são pessoas inseridas em redes de vizinhança e freqüência religiosa, redes de proximidade que podem ser percebidas como “tradicionais"20 que constituem a maioria dos freqüentadores das aparições. Cada excursão com destino aos rituais é formada por determinados grupos, que já possuíam contatos e relações anteriores. Inclusive, ao observarmos os Cenáculos é perceptível a presença de vários “grupinhos” que circulam, conversam, comem e que já se conheciam anteriormente, e não de um todo unitário que se constituiu para a aparição. Assim, quando analisamos as aparições de Nossa Senhora no Brasil percebemos que a freqüência a estas manifestações está também relacionada com as redes de relações religiosas dos participantes.

Dessa forma, o ponto de partida das peregrinações são as paróquias e a vizinhança, as relações pessoais. Não podemos afirmar, então, que a Instituição Católica esteja ausente neste processo, pelo contrário, é a partir dela, de sua organização institucional - a paróquia -, de seus rituais - como a missa - e de seus movimentos especialmente a RCC - que a informação sobre as aparições de Nossa Senhora é disseminada. Ou seja, a perda de poder da Instituição Católica, afirmada por HervieuLéger, também pode ser questionada. A autora considera que a instituição católica na atualidade perde poder, se enfraquece. Esse enfraquecimento está relacionado com a diminuição do grau de controle exercido por ela sobre os fiéis, sendo isso parte da modernidade religiosa. Entretanto, ela relaciona controle e práticas doutrinariamente estabelecidas, quanto mais de acordo com os dogmas religiosos, mais controlado é considerado o fiel. No caso dos peregrinos esse grau de controle é quase inexistente, diferente do praticante regular, em que o seguimento doutrinário era central.

\footnotetext{
${ }^{20}$ Constatamos que elementos presentes nas peregrinações para os Santuários tradicionais - como o de Bom Jesus da Lapa, na Bahia - podiam também ser observadas nas Romarias para os Cenáculos Marianos, especialmente no que se refere à importância da comunidade local e dos laços de parentesco para a sua organização.
} 
Entretanto, observamos que a instituição católica se faz presente nas aparições marianas. De fato, são fenômenos que em muitos casos são colocados à margem da Igreja, devendo passar por longos processos antes de seu reconhecimento. Porém, isso se refere à Igreja Oficial, à ortodoxia do catolicismo, pois quando aprofundamos um pouco a observação, nos detendo nos participantes desses fenômenos, percebemos o seu vínculo com a Igreja e a importância da rede de relações paroquiais na presença de pessoas nestes locais. Os peregrinos que tomam a iniciativa para a organização da Romaria, mobilizando uma rede de contatos, estão diretamente ligados à paróquia, seja pela participação em movimentos doutrinários da Igreja para o recebimento dos sacramentos - como catequistas, palestrantes para grupos de noivos ou responsáveis por grupos de crisma - seja pela participação nos movimentos leigos principalmente a RCC.

Assim, podemos não perceber a presença direta da instituição nestes eventos, nos termos adotados por Hervieu-Léger. De fato a Igreja não recomenda a presença de sacerdotes e a administração de sacramentos nestes locais antes de seu reconhecimento. Entretanto, mesmo não estando presente através de seus sacerdotes e sacramentos, ela está ali representada através de seus movimentos leigos.

Dessa maneira, existem novas características na forma de se exercer a religiosidade no contexto contemporâneo, que podem ser notadas nas aparições marianas e que alteram as relações entre os indivíduos e a Igreja. Entretanto, estas alterações estão mais relacionadas com o papel dos movimentos leigos - no caso das aparições com o movimento carismático - do que com a perda de poder da Instituição.

Destacamos a importância central da mediação dos movimentos leigos para a Igreja Católica, especialmente do movimento carismático. Ao longo do capítulo observamos a importância da RCC em dois tipos de relações estabelecidas, mas de maneiras diferentes. Primeiro ela é notada a partir das práticas rituais locais dos peregrinos, sendo por meio dos grupos de base do movimento, especialmente os grupos de oração e terços, através da divulgação “boca a boca”, entre freqüentadores de uma mesma paróquia, entre vizinhos, que as informações circulam e as peregrinações são organizadas.

Segundo, nas conexões estabelecidas através dos meios de comunicação como a televisão e a internet - que divulgam Cenáculos Marianos, visitas de palestrantes internacionais ou nacionais às comunidades, e excursões para Santuários. 
Novos contatos são estabelecidos desta maneira. Por exemplo, uma excursão aos Santuários marianos europeus, divulgada pela rede de televisão "Canção Nova”, coloca em contato devotos do Brasil todo, que a partir de então começam a compartilhar informações e organizar excursões e outros eventos em comum ${ }^{21}$. Assim, as novas relações podem gerar novas articulações e configurações para a rede, pois são passíveis de acessar novos elos para eventos posteriores.

Segundo Brenda Carranza, esse movimento leigo está organizado, desde seu início, de forma burocrática e planejada, fator que muito contribuiu para a sua expansão por todo o país. Segundo a autora, a penetração do movimento nas cidades de pequeno e médio porte ${ }^{22}$ resulta dos planos traçados pela coordenadoria nacional, que todo ano realiza uma reunião com a “cúpula” do movimento, na qual traça um plano de metas para a expansão da RCC. Trata-se, pois, de um movimento que possui organização hierárquica e burocrática, centrada em coordenadorias - nacional, estadual, regional e municipal - sendo que as decisões e estratégias do movimento passam por essa organização ${ }^{23}$.

Vale a pena destacar algumas características da RCC que contribuem para o papel de mediação realizado por ela nas aparições de Nossa Senhora. A RCC, apesar de vinculada a Igreja Católica e de professar obediência a seus sacerdotes, possui uma organização paraparoquial, em que muitas das decisões partem da hierarquia do movimento, e não da hierarquia da Igreja Católica ${ }^{24}$. Trata-se de um movimento leigo

\footnotetext{
${ }^{21}$ Isso não é uma regra, bem como não são todos os participantes que efetuam contatos posteriores, mas, em vários relatos pudemos observar que as excursões, como os Santuários, colocam pessoas de diferentes locais em contato, efetuando relações e conexões a partir desse primeiro contato.

${ }^{22}$ Segundo autores que estudaram a RCC na década de oitenta e início da década de noventa - Benedetti (1985), Prandi (1994) e Campos Machado (1992) - ele era caracterizado como um movimento presente nos grandes centros urbanos, com integrantes pertencentes, principalmente, a classe média alta. Com a grande expansão do movimento durante a década de noventa, esse perfil se altera, sendo que, na atualidade a RCC encontra-se presente em paróquias de todas as camadas sociais e em cidades de todos os portes.

${ }^{23}$ No que se refere aos rituais, a RCC possui rituais que podem ser considerados de base, os grupos de oração, pequenos rituais realizados semanalmente e que estão presentes em inúmeras paróquias e que congregam os membros locais da Renovação Carismática. A expansão da RCC pelo país ocorreu através da implantação de grupos de oração pelas paróquias. Por outro lado, a Renovação Carismática também realiza mega eventos, em estádios de futebol, com a presença de seus membros de maior destaque - como Pe Marcelo Rossi, Pe Zeca - e também de artistas vinculados ao movimento, que costumam chamar a atenção da mídia.

${ }^{24}$ Inclusive, as relações entre carismáticos e a hierarquia católica são freqüentemente tensas, devido, em grande parte, a autonomia da RCC, não apenas no que se refere a estratégias e decisões, mas também na autonomia do contato com as figuras divinas - o Espírito Santo e a Virgem Maria. Entretanto, essas relações de tensão variam de acordo com as situações, com o posicionamento teológico do pároco e com a aceitação de suas decisões pelas lideranças carismáticas locais. Como, na atualidade, padres vinculados a RCC são bastante comuns, as relações de tensão podem não ocorrer.
} 
que possui grande autonomia em relação à hierarquia da Igreja Católica. Inclusive, essa autonomia é também financeira, pois a RCC é um movimento bastante rico, que faz importantes campanhas de arrecadação entre seus membros e costumam obter bastante sucesso. Exemplo disso é a comunidade "Canção Nova”, localizada na cidade de Cachoeira Paulista, no interior de São Paulo, que possui o maior templo do Brasil, todo construído com o dinheiro arrecadado entre os membros da RCC.

Vale a pena também mencionar as comunidades carismáticas, chamadas “comunidades de aliança e vida no Espírito Santo”. No caso do Brasil, este é um fenômeno recente, datando do final da década de noventa, mas, apesar disso, presente em inúmeras cidades brasileiras. São constituídas por leigos, que decidem se reunir para se dedicar ao louvor, à adoração ao Santíssimo, à evangelização, à cura espiritual e às obras sociais. As comunidades de vida são formadas por pessoas que dividem um mesmo lar, já no caso das comunidades de aliança as pessoas continuam a morar com seus familiares e mantêm sua autonomia financeira. Devido às menores exigências, as comunidades de aliança são mais numerosas no país. Importa destacarmos que, de maneira semelhante ao próprio movimento, essas comunidades possuem grande autonomia em relação à Igreja Católica, tanto financeira - sendo responsáveis por sua manutenção econômica - quanto no que se refere às atividades religiosas realizadas.

O fato de se tratar de um movimento leigo e com uma organização hierárquica burocraticamente instituída e com relativa autonomia em relação à organização eclesial da Igreja Católica constitui uma característica importante do movimento carismático em relação às aparições de Nossa Senhora, como demonstraremos ao longo da tese.

Devemos, então, discutir o lugar da mediação atualmente nas instituições, e mais especificamente na Igreja católica. Podemos considerar como mediadores, ou como corpos intermediários, os movimentos de leigos ligados à Igreja Católica, mas que possuem certa independência em relação a ela, cujo melhor exemplo - e também o mais importante para a nossa análise - é a Renovação Carismática. Esse movimento, apesar de possuir religiosos e religiosas entre seus membros, é composto por uma estrutura hierárquica independente e paralela a hierarquia católica, sendo estruturado em Comissões - Comissão Municipal, Comissão Regional, Comissão Estadual, Comissão Nacional e Comissão Mundial. Uma característica da importância da hierarquia paraeclesiástica da RCC é a existência de uma formação específica para as lideranças realizada pelo movimento, sem relação com a oficialidade católica. Além disso, seus 
membros devem se reportar aos superiores na hierarquia carismática, devendo obediência a eles. Dessa maneira, trata-se de um movimento da Igreja Católica, mas que possui alguma independência em relação a ela, como demonstrado no primeiro capítulo, e que por isso serve como exemplo para a discussão sobre os corpos intermediários - no caso os novos movimentos leigos - na instituição católica.

A concepção de corpos intermediários vem da sociologia das instituições, sendo que, segundo os estudiosos, estes elementos ocupam um lugar cada vez mais importante nas últimas décadas, sendo considerados como uma barreira contra o autoritarismo e centrais na constituição da democracia pluralista, garantindo ativamente a liberdade dos cidadãos. Segundo Palard (2006), as associações têm como principal função estabelecer a ligação entre o Estado democrático e o cidadão e de protegê-los contra o despotismo. Nesse sentido, eles são concebidos como uma esfera intermediária entre o poder e os cidadãos, responsável pelo elo entre eles, mas também pela garantia das liberdades e da proteção dos cidadãos. Destacamos que as práticas e movimentos de mediação estão presentes em vários setores da vida social e política das sociedades contemporâneas, sendo marcantes das relações entre os indivíduos e as instituições.

A questão é se podemos transpor estes princípios de mediação entre indivíduo e instituição presentes na sociedade política para as relações entre a Igreja e seus fiéis, considerando que a instituição católica está hierarquicamente estruturada sob as bases de um poder centralizador - o Vaticano - cujo poder despótico não deve ser questionado devido ao dogma da infalibilidade papal, ou seja, suas decisões representam a vontade de Deus, e por isso não são passíveis de falhas. Segundo Palard (2006), esta transposição apenas pode ser feita dentro de certos limites, sobretudo no que se refere à manutenção da unidade disciplinar e doutrinária, que deve primar sobre a liberdade, não podendo ser dividida nem negociada. Dessa maneira, o exercício do poder na Igreja Católica continua sendo exercido de forma hierárquica e centralizada, sendo sustentado pelos princípios da verdade divina e da unidade doutrinária, dos quais a Instituição não abre mão. Assim, a participação dos leigos e a ação dos novos movimentos somente podem ocorrer dentro de determinados limites impostos pela hierarquia, sendo o principal deles a fidelidade à doutrina católica.

Dessa forma, o movimento carismático também deve fidelidade a esta doutrina, e é justamente por que se adequou a ela que consegue se disseminar com grande força a partir de meados da década de noventa. Apesar de ser um movimento 
bastante polêmico, especialmente em seu início, ele não rompe com a doutrina católica, pelo contrário, os carismáticos fazem questão de se proclamarem como católicos, enfatizando dogmas caros a essa religião, como a importância dos sacramentos e a infalibilidade do $\mathrm{Papa}^{25}$.

A RCC realiza a mediação entre o individuo e a Instituição, organizando e divulgando rituais católicos, como no caso demonstrado das peregrinações e cenáculos marianos. Entretanto, como destacado por Palard, essa mediação deve se ater aos dogmas do catolicismo, como no caso demonstrado da devoção a Nossa Senhora nos rituais carismáticos, imposta a princípio pela Instituição para aproximar o movimento da religiosidade católica e que, embora resignificada de acordo com as práticas rituais carismáticas, teve de ser incorporada pelo movimento. Também no caso da organização de Cenáculos notamos alguma autonomia por parte da RCC, como no exemplo da visita da Virgem do mel a comunidade Magnificat, “escondido do bispo”, demonstrando uma contravenção realizada pela comunidade, mas demonstrando principalmente que mesmo diante de sua relativa autonomia, a comunidade deve se submeter às determinações da diocese.

Uma das novidades da RCC é, pois, a forma como consegue manter-se forte dentro da Igreja Católica e, ao mesmo tempo, possuir uma relativa autonomia em relação a ela. Nesse sentido, ainda existem muitas polêmicas entre a RCC e os párocos, por exemplo, a presença de determinados elementos nos cultos carismáticos são alvo de muitas críticas por parte de membros da hierarquia, especialmente sacerdotes, devendo ser constantemente negociados entre os carismáticos e o pároco da localidade, em cada situação específica ${ }^{26}$. Entretanto, a RCC tem também as suas comunidades, não dependendo apenas da paróquia para realizar seus rituais, e possuindo, então, uma independência ainda maior em relação à hierarquia católica - embora estas comunidades devam se reportar ao bispo da diocese em que estão localizadas, elas

\footnotetext{
${ }^{25}$ No que se refere a infalibilidade do Papa, notamos um apego especial a figura de João Paulo II. Não haveria apenas a ênfase no dogma em relação a qualquer Papa, mas especificamente a ele. Ou seja, João Paulo II era considerado infalível, e não todos os Papas.

${ }^{26}$ O caso do repouso no Espírito Santo talvez seja o mais contundente. Neste momento ritual uma liderança carismática impõe as mãos sobre a cabeça de um fiel, realizando algumas orações, sendo que, em seguida, o fiel perde os sentidos, caindo no chão, em transe. Segundo os carismáticos, a pessoa foi "tomada" pelo Espírito Santo, que o fez perder os sentidos. Essa prática carismática é alvo de muitas críticas pelos sacerdotes, sendo que a maioria deles não permite a sua realização em suas paróquias. Entretanto, os carismáticos não deixam de realizá-la, embora de maneira mais "escondida" durante seus rituais "fechados", ou seja, aqueles em que estão presentes apenas carismáticos mais antigos no movimento.
} 
possuem uma grande autonomia financeira e ritual, pois não estão localizadas no espaço físico da Igreja, sob a vigilância do sacerdote.

Assim, a intermediação dos movimentos de leigos, especificamente da Renovação Carismática, não ocorre de maneira simples e tranqüila na Instituição Católica, sendo sempre alvo de críticas e embates. Isso não impede, porém, a maior autonomia destes movimentos na atualidade. Inclusive, podemos pensar na importância deles para a manutenção do poder da Igreja Católica, pois são justamente os movimentos que mais crescem e arregimentam fiéis nas últimas décadas.

A relação entre a Instituição e os movimentos leigos é bastante complexa, pois abarca, de um lado, movimentos relativamente autônomos, mas que devem fidelidade à doutrina católica. Entretanto, justamente a autonomia dos movimentos contribui para a manutenção dos fiéis no catolicismo, tornando-os fundamentais para a Igreja na atualidade.

Além disso, devemos destacar que os movimentos leigos de mediação, nos moldes da RCC, demonstram um funcionamento religioso mais reticular e menos hierarquizado, menos centralizado e mais segmentar. $\mathrm{O}$ acionamento em rede para a realização dos Cenáculos marianos nos demonstrou isso, são elos acionados que organizam as peregrinações para os rituais. Esse novo tipo de funcionamento religioso não exclui a participação dos sacerdotes, mas ele ocorre por meio dos movimentos, e não pela hierarquia católica, ou seja, os sacerdotes são convidados pelos integrantes do movimento para participar, ou são eles próprios integrantes dos movimentos.

A presença do movimento carismático por todo o país também demonstra esta reticularidade, estando presente em numerosas paróquias. Como mencionamos, houve uma estratégia desenvolvida pelo movimento para implantar seus rituais no maior número de paróquias, objetivo alcançado com bastante sucesso. Assim, os grupos de oração da RCC estão presentes em todo o país, sendo organizados e liderados por leigos da localidade, que compartilham a realização de práticas rituais com os sacerdotes locais.

Assim, a instituição católica continua presente nesta nova forma de agir religioso, representada pela intermediação dos movimentos leigos, buscando não perder seus fiéis e não diminuir seu poder ${ }^{27}$.

\footnotetext{
${ }^{27}$ A própria autora, ao descrever as Jornadas para a Juventude em Paris, estudo de caso a partir do qual desenvolve a figura do peregrino, aponta a presença da Igreja e algumas tentativas de adaptação realizadas por ela a esse movimento "desistintucionalizado" - são realizadas missas, ministrados
} 
Nesse sentido, a obra de Philippe Portier (2006) “O pensamento de João Paulo II” nos trouxe importantes reflexões sobre a Instituição Católica e as políticas adotadas por ela na contemporaneidade. Apontamos algumas questões importantes levantadas por este autor e que nos ajudam em nossa análise.

Portier defende a idéia de que o papado de João Paulo II produziu um modelo de ajustamento - e não de adesão - à modernidade. O autor realiza uma análise aprofundada do pensamento wotjiliano, apoiando-se na Sociologia das Instituições para explicar o pensamento de João Paulo II. Em suas palavras: “A sociologia das instituições revela que face ao movimento da história as organizações têm apenas três escolhas: a retração, a ligação ou o ajustamento. É nesta terceira via que se encontra o Papa Polonês" 28 .

Assim, considera que João Paulo II, em suas encíclicas e discursos, fornece “uma alternativa antimoderna para a modernidade”, integrando léxicos e conteúdos próprios da filosofia nascida no Iluminismo - como os direitos do homem e a liberdade religiosa -, que não estavam presentes no momento pré-conciliar. Entretanto, segundo Portier, esses conteúdos são secundários, pois não abalam a estrutura do pensamento wotjiliano, servindo apenas para ajustar suas declarações aos anseios de uma época fundamentada sobre a exaltação do sujeito livre e soberano. O pensamento de Karol Wojtyla seria, pois, uma continuidade em relação ao integralismo anterior ao Concílio Vaticano $\mathrm{II}^{29}$, mas não uma permanência absoluta, existindo elementos que são incorporados e reelaborados em suas encíclicas e discursos.

Dessa maneira, demonstra as continuidades do pensamento de João Paulo II, em que, em suas palavras "o novo se liga ao antigo sem o subverter" demonstra no capítulo preliminar de seu livro a gênese do pensamento wotjiano e sua

sacramentos, mas sem o caráter obrigatório que antes marcava o catolicismo, segundo ela. Assim, a instituição não está ausente destas manifestações. Aprofundaremos esse ponto, sobre o qual se estrutura o segundo capítulo de nossa tese, relacionado ao papel, as posturas e as práticas adotadas pela Igreja Católica frente às aparições de Nossa Senhora.

${ }^{28}$ Essa concepção de Portier vem em resposta a duas linhas de análise do pensamento de João Paulo II: uma que o considera como o Papa da Revolução, pois continua com a linha dissociativa dos dois Papas anteriores, realizando uma adaptação da Igreja à modernidade, e uma segunda que o considera como o Papa da restauração, pois retrocede em avanços estabelecidos pelo Concílio Vaticano II

29 Essa continuidade se manifesta em três princípios: Princípio de veracidade, que considera que a verdade subsiste na Igreja Católica, não apenas no domínio espiritual, mas também no domínio temporal; princípio de oposição, que considera que as sociedades bem estruturadas estão baseadas na religião, atacando todos os sistemas de pensamentos saídos da revolução de 1789 que pretendem construir as cidades terrestres apenas sobre o poder do humano; e o princípio de restituição, que considera que o mundo deve ser organizado de acordo com as regras definidas pela Igreja.

${ }^{30}$ Neste primeiro volume sobre o pensamento de João Paulo II, procura demonstrar como o Papa, fiel a idéia de uma ligação necessária entre a cidade dos homens e a cidade de Deus, denuncia os sistemas liberal e marxista. O livro está dividido em capítulos que procuram explicar esta questão. 
importância para o modelo de um ajustamento, e não adesão, à modernidade. Demonstra como a formação pessoal de Karol Wotjyla, desde sua infância na Polônia, contribui e é coerente com os elementos constitutivos do pensamento de João Paulo II, especialmente no que se refere à continuidade em relação aos valores "tradicionais" do catolicismo. Ele demonstra a contribuição das leituras e encontros, do estudo e do teatro, da faculdade e do apostolado na formação de uma estrutura de pensamento que torna possível a sua adesão a um modelo de intransigência “modernizada”. As devoções do adolescente Karol Wotjyla - características do catolicismo tradicional polonês - e suas leituras de autores do romantismo polonês - que estavam na contracorrente da modernidade - contribuíram para a introjeção de valores antimodernos. Esses valores continuam presentes no pensamento de João Paulo II, mas ganham nova roupagem, pela utilização de um léxico característico da “modernidade”.

Portier também destaca que é nesse momento, em sua infância, que sua devoção a Nossa Senhora surge e é consolidada. Desde criança é levado pelo pai aos Santuários Marianos da região, sendo que mais tarde, na adolescência, freqüenta todas as tardes uma paróquia cuja padroeira é Maria, para orar e lhe render homenagens.

Importa-nos reter, sobre o livro de Phillipe Portier, não a sua importante análise sobre o pensamento de João Paulo II, mas a reflexão sobre esse modelo de ajustamento presente em suas encíclicas e discursos, e que se estende para práticas políticas de seu papado. Assim, destacamos a idéia de que não há uma adequação à modernidade, mas sim um ajustamento, em que os elementos presentes anteriormente em um contexto de religião “tradicional” não desaparecem e nem são deixados de lado, pelo contrário, permanecem como eixo central das políticas e práticas adotadas, embora utilizando elementos e expressões que pertencem a esse novo contexto, chamado pelo autor de modernidade ${ }^{31}$. Dessa forma, há a utilização do léxico característico das formas de pensamento surgidas com a modernidade - especialmente o liberalismo e o marxismo - mas o sentido dado a eles não é semelhante a seu sentido original, presente nestas formas de pensamento. Exemplo disso é a análise da postura de João Paulo II diante do liberalismo, em que demonstra a resistência do Papa à homogeneização liberal

\footnotetext{
${ }^{31}$ Importa destacarmos que Portier refere-se em seu livro principalmente às ideologias surgidas e desenvolvidas durante a modernidade - o liberalismo e o marxismo. Dessa maneira, quando menciona o conceito modernidade está fazendo referência a estas duas doutrinas. Ou seja, diferente de Hervieu-Léger, ele não está preocupado em caracterizar a modernidade, mas sim em analisar as utilizações feitas por João Paulo II sobre termos característicos destas duas formas de pensamento modernas. Assim, quando menciona a modernidade está fazendo referência a elementos destas doutrinas surgidas durante o período moderno.
} 
do mundo ${ }^{32}$, rejeitando-a tanto em seu aspecto político como econômico. Portier analisa os argumentos e conceitos utilizados pelo Papa para a rejeição do capitalismo liberal em dois capítulos, respectivamente sobre a questão política e a questão econômica, abordando a utilização de termos do léxico liberal pelo Papa em suas encíclicas e discursos. Entretanto, demonstra a filiação teológico/filosófica desses termos, analisando como eles ganham novos sentidos, que os distanciam de seu sentido original presente no liberalismo. Ou seja, João Paulo II usa o vocabulário liberal em seus discursos, mas o sentido dos termos não é o mesmo, pelo contrário, em muitos casos ele discorda do sentido original das palavras do léxico liberal.

Esse é, portanto, o modelo de ajustamento defendido pelo autor, em que ocorre a inserção de novos termos e temas no discurso papal, porém sem subverter as concepções “antigas e conservadoras” presentes no Vaticano, que também fazem sentido quando relacionadas à biografia de Karol Wotijla. São vários elementos, pois, que contribuem para esse resultado classificado por Portier como "ajustamento" que justifica o pensamento do papa polonês.

Assim, o estudo desenvolvido por Portier demonstra que a Instituição Católica se mantém na atualidade, e que não desenvolve “estratégias” para “sobreviver” ou para se "adequar" a esse novo contexto, mas que possui poder e influência, mantendo seus conteúdos e dogmas centrais, mas de uma forma mais “aceitável” no mundo contemporâneo.

Na verdade, essa incorporação do novo serve para a continuidade da Igreja Católica, que não abandona seus valores, símbolos e crenças, mas acrescenta a eles o uso de termos e práticas pertencentes ao mundo contemporâneo para manter seu poder e influência na atualidade. Isso foi observado ao longo deste capítulo em vários fatores: pela centralidade dos movimentos de intermediação no catolicismo atual; pela utilização de recursos e meios de comunicação importantes no mundo contemporâneo principalmente a TV e a internet - e pela circulação de pessoas, de manifestações e de

\footnotetext{
${ }^{32}$ No que se refere ao liberalismo, Portier coloca que o Papado de João Paulo II coincide com um período de forte expansão do liberalismo, especialmente nos anos entre 1975 e 1980. Essa expansão ocorre, primeiramente, na economia, com a diminuição do estado, querendo reduzi-lo apenas à gestão da ordem e da segurança pública. Em seguida, na esfera política, com a enorme expansão dos estados republicanos. Entretanto, o que de fato surpreende o Vaticano é a expansão do pluralismo axiológico, pois, mesmo nos países de tradição católica ocorrem modificações nas regras do direito, que se separam do direito natural, especialmente as regras referentes à família, como a legalização do divórcio, a descriminalização do aborto e a aceitação do casamento homossexual. Nesta nova conjuntura, ao Estado cabe apenas o papel de preservar a capacidade de autodeterminação dos sujeitos, pois os fatores antes instituídos como crimes passam a ser concebidos como escolhas individuais.
} 
informações por uma rede desterritorializada e chave para a organização dos Cenáculos Marianos. Esse tema retornará em capítulos posteriores, como na análise dos elementos simbólicos das aparições. 


\section{SEGUNDO CAPÍTULO}

\section{A PRESENÇA DA IGREJA NAS APARIÇÕES CONTEMPORÂNEAS}

Neste capítulo demonstraremos a importância da presença da Igreja Católica na produção de teorias e da legitimidade das aparições marianas contemporâneas. Essa influência ocorre por meio de seus representantes, pertencentes à hierarquia católica. Continuamos, pois, o argumento que finaliza o primeiro capítulo, demonstrando a permanência do poder e da influência da Instituição católica, constatada através do papel central desempenhado por seus teólogos e sacerdotes nestes fenômenos, produzindo crenças e práticas que circulam e são apropriadas pelos participantes das manifestações marianas da atualidade.

Dessa maneira, há importantes devotos das aparições na alta hierarquia católica - nos deteremos em dois deles: o teólogo René Laurentin e o Papa João Paulo II - cujas idéias e práticas circulam entre os participantes desses fenômenos, sendo reproduzidas por eles.

Além disso, observamos que a Igreja Católica desempenha também um papel importante para a constituição da legitimidade destes fenômenos. Este processo de legitimação mobiliza várias instâncias, grupos e representantes da Igreja, sendo que a aceitação ou rejeição de uma aparição é alvo de disputas internas, como entre os teólogos e entre setores e grupos, sendo cada caso analisado, debatido, defendido ou combatido antes de ser reconhecido. Trata-se, pois, de um universo marcado por controvérsias que opõem defensores e opositores dos “eventos extraordinários”, entre os quais se encontram as aparições de Nossa Senhora.

Nos remetemos a uma citação de Denis Pelletier, que nos lembra "que l'Église, comme toute institution historique, est aussi un champ d'affrontement où le rapport de forces se noue autour de la définition d'une légitimité croyante”. Não é nossa intenção neste capítulo descrever esse importante campo de disputas constituído pela Igreja Católica em torno das aparições de Nossa Senhora ${ }^{33}$, mas apenas destacar que não existe um posicionamento único e homogêneo a seu respeito, pelo contrário,

\footnotetext{
33 Esse campo de análise é muito amplo e complexo, não sendo possível esgotá-lo propriamente em apenas um capítulo.
} 
cada caso, mesmo os que parecem mais consensuais - como Lourdes e Fátima, por exemplo - ainda são alvos de discussões entre os teólogos marianos.

Entretanto, não é apenas no âmbito teológico que as discussões e disputas acontecem. Elas se estendem para outros níveis e setores da Igreja, desde a Paróquia até o Vaticano, podendo ser observadas em posturas e políticas adotadas pelos sacerdotes desde o Pároco da comunidade até o Papa. Existem, pois, diferentes planos de análise, desde um plano institucional mais distante - especialmente o Vaticano e as políticas e práticas estabelecidas por ele através de seu representante -, até um plano de análise mais próximo dos fenômenos, que ocorre nos locais das manifestações, nas relações estabelecidas com o bispo da localidade - primeiro a realizar um parecer sobre as aparições - e os sacerdotes das proximidades.

As posturas adotadas nos diferentes planos exercem influência sobre as aparições, constituindo um fator importante para a atribuição ou não de legitimidade a um fenômeno. Dessa maneira, demonstraremos que a interferência da Instituição sobre as aparições marianas aparece em diferentes âmbitos, desde o local, em que os sacerdotes e bispos das comunidades desempenham papel central, até os critérios adotados pelo Vaticano sobre esses eventos e as práticas do Pontífice - especificamente João Paulo II - em relação a elas. E, principalmente, analisaremos como estas posturas exercem impacto positivo ou negativo sobre a legitimidade das aparições.

Em cada um destes planos existem atores e grupos dispostos a defender e legitimar as aparições de Nossa Senhora. Elas possuem importantes defensores no corpo da Igreja, não apenas entre os sacerdotes - padres, bispos e arcebispos - mas entre os teólogos e principalmente o Papa João Paulo II.

No plano teológico uma figura se destaca: Padre René Laurentin, considerado o mais importante teólogo mariano da atualidade e ardente defensor das aparições de Nossa Senhora. Mesmo não estando presente entre os dogmas da Igreja, não sendo parte de sua doutrina, as aparições são teologicamente defendidas pelo Padre René Laurentin, especialista neste tipo de fenômeno e que contribui com a formulação e disseminação de importantes idéias e crenças sobre as aparições. Suas concepções sobre as manifestações marianas circulam pelo mundo todo, pois, além de teólogo, ele realiza palestras sobre esse tema em diversos países. Sua incessante defesa e divulgação das 
“manifestações extraordinárias” contribuem para a atribuição de legitimidade a eventos na atualidade ${ }^{34}$.

Dessa maneira, a Instituição não está à parte nestas manifestações, pelo contrário, há teólogos em sua hierarquia preocupados em analisá-las e fundamentá-las doutrinariamente, existindo, inclusive, calorosos debates teológicos sobre cada manifestação ${ }^{35}$. Antes de nos aprofundarmos na argumentação de defesa de Laurentin, atentamos para a existência de critérios de análise estabelecidos pelo Vaticano em relação às aparições. Estamos nos referindo aos critérios mais gerais adotados pela Igreja nos casos de aparição, e não aos casos específicos - pois para cada manifestação ocorre um longo processo de análise no local, envolvendo atores e jogos de força específicos, que serão analisados posteriormente.

Ainda com relação à Instituição Católica, em seu plano “oficial”, não podemos deixar de mencionar a importância da figura de João Paulo II, que por meio de sua devoção a Nossa Senhora e da sua peregrinação entre os Santuários marianos, inclusive os de aparição, recoloca Maria como figura central do catolicismo - no plano institucional - e incentiva e legitima a devoção a ela entre os católicos. Por isso um dos itens deste capítulo será dedicado à análise das posturas de Karol Wotjyla sobre Nossa Senhora, especialmente sobre as aparições marianas.

Assim, neste capítulo analisamos as políticas e práticas eclesiásticas em relação às aparições de Nossa Senhora. Porém, não nos deteremos nas disputas locais envolvendo os representantes da Igreja - que serão analisadas em capítulo posterior -, mas nas posturas adotadas por membros iminentes da Igreja, que ocupam postos de destaque na hierarquia católica, e que têm atitudes e produzem idéias que são chaves para a constituição da legitimidade das aparições de Nossa Senhora na atualidade.

Como demonstrado no primeiro capítulo, as aparições não são fenômenos isolados, mas mantêm relações com uma série de manifestações do mesmo tipo, às quais devem estar conectadas para obter legitimidade. A Igreja Católica é parte importante deste processo, pois de sua atuação depende o sucesso desses eventos. Assim, na primeira parte deste capítulo analisamos, além dos critérios oficiais para a

\footnotetext{
${ }^{34}$ Importa destacar que os teólogos defensores dos "eventos extraordinários” estão na contracorrente da teologia católica dominante na atualidade - que a partir da segunda metade do século XX e mais intensamente após o Concílio Vaticano II, não vê com bons olhos as "manifestações extraordinárias".

${ }^{35}$ Um exemplo desses debates na atualidade diz respeito às aparições da Virgem na Vila de Medjugorje, que apesar de não possuir o reconhecimento da Igreja é um dos maiores santuários marianos da atualidade e sobre o qual dois importantes teólogos católicos - René Laurentin e Philipe Bouflet - estabelecem uma disputa teológica sobre a veracidade ou não das manifestações.
} 
avaliação das aparições de Nossa Senhora, a importância do teólogo René Laurentin na produção de idéias em defesa desta devoção.

A importância da Igreja na produção da legitimidade das aparições marianas já havia sido observada por autores que analisaram estes fenômenos na França no século XIX. Vale a pena retomar alguns pontos desta análise antes de enfocarmos a influência da Igreja nos eventos contemporâneos.

1) A Igreja e as aparições do século XIX

As aparições de Nossa Senhora para videntes apresentam um aumento significativo a partir da segunda metade do século XIX. Neste período ocorre o reconhecimento de algumas aparições que se estabelecem como marcos para o catolicismo. Estas manifestações ocorrem principalmente na França, onde a Igreja reconhece sucessivamente três episódios: Rue du Bac, em 1830, La Salette, em 1846, e Lourdes, em 1858.

O envolvimento do clero com as aparições do século XIX foi central para o sucesso destas manifestações. Embora os fenômenos de contato entre a Virgem e os homens já estivessem historicamente presentes no catolicismo, havendo vários elementos simbólicos de continuidade entre as visões medievais e as aparições do século XIX, apenas neste momentos que se promove a intervenção da Igreja em prol destas manifestações.

Essa é uma novidade importante. Segundo Albert Lorca, especialmente na França, houve uma estratégia da Igreja para reconquistar seus fiéis por meio da utilização das aparições marianas. Assim, se até aquele momento as regras instituídas pela Igreja para a análise dos fenômenos serviam apenas para que ela exercesse o controle sobre elas e evitasse os chamados excessos, a partir do século XIX essas regras são utilizadas em benefício das próprias aparições. Nas palavras de Albert-Lorca, as aparições "dão um novo impulso ao culto mariano e tentam relançar, contra o cientificismo, a crença nos milagres”. (2001:56). O interesse da Igreja por estas manifestações ocorre, pois, em um contexto em que o cientificismo vem ganhando cada vez mais espaço, sendo ele uma forma de reação da Igreja.

A intervenção sobre as aparições marianas ocorre principalmente por meio de uma rede de clérigos que se envolve com as manifestações. Segundo Gillet (1994), essa rede, composta principalmente por padres e bispos, engaja-se no reconhecimento e 
na divulgação do "fato sobrenatural que ocupa toda a França" e que estabelece relações entre as aparições ocorridas na Rue du Bac (Paris), La Salette e Lourdes. Especialmente sobre La Salette o autor demonstra a importância do envolvimento do clero da região e de pessoas de credibilidade que estão convencidas da veracidade das aparições, como o bispo de Grenoble, pessoa pública importante e que acredita na manifestação. Segundo este autor, é esta mesma rede que estabelece a conexão entre La Salette e outras manifestações ocorridas pouco antes na França.

As três aparições mencionadas, conectadas por meio de uma rede de divulgação estabelecida pelos clérigos, são consideradas pelos historiadores do catolicismo - como Albert-Lorca, como inaugurais. No entanto, as três aparições em questão possuem mais elementos de disparidade do que de continuidade, especialmente a aparição da Virgem para Santa Catarina de Labouré, na capela da Rue du Bac, em Paris. A conexão e a continuidade entre elas foram estabelecidas pelos clérigos, como demonstrado por Gillet, e não constitutivas dos fenômenos em si.

Nesse sentido, a aparição da Rue du Bac, mais conhecida no Brasil como "Medalha Milagrosa”, possui características mais próximas das visões de Nossa Senhora para religiosos, como as existentes no período anterior, do que das aparições modernas. Trata-se de uma aparição privada para uma freira, dentro de uma capela segundo os relatos, Nossa Senhora aparece para a Irmã Catarina de Labouré na capela da Rue du Bac, ou seja, nada de muito novo em relação às visões medievais. Nesta aparição a Virgem pede que seja cunhada uma medalha em seu nome, a medalha milagrosa, mas Santa Catarina mantém a aparição em segredo durante muitos anos, relatando-o apenas para o seu confessor, que a estimula a atender ao pedido da Virgem. Assim, após relutar durante alguns anos, ela acaba por revelar ao bispo a "vontade de Maria”, que não vê nenhum problema na realização da medalha, porém, sem associá-la às aparições. A medalha é então forjada sem a divulgação das visões, sendo que apenas anos mais tarde, quando ganha a fama de miraculosa, as aparições para Santa Catarina são reveladas.

A divulgação desta manifestação é então realizada pelo clero, que contribui para o reconhecimento da aparição e atribuição do poder milagroso à medalha. O estudo realizado por Gillet demonstra que as características da aparição da Rue du Bac são semelhantes as das visões privadas para religiosos - como as visões medievais, ela acontece no âmbito de um convento, para uma freira, e possui um caráter privado, e não público, sendo a mensagem destinada exclusivamente para Catarina e não para a 
humanidade. A publicidade desta manifestação se deve ao empenho de uma parte do clero em forjar a medalha e divulgá-la, e, junto com ela, a aparição.

Gillet, porém, não estabelece uma separação entre as aparições anteriores ao século XIX e as posteriores, detendo-se na semelhança entre as manifestações ocorridas na França durante a chamada restauração, demonstrando em seu livro "La rumeur de Dieu: apparitions, propheties e miracles sous la restauration”, que a conexão existente entre elas foi estabelecida pelo clero. Nestas manifestações - localizadas e datadas pelos historiadores do catolicismo na França do século XIX, - o investimento dos representantes da Igreja é, pois, central. Os estudos mostram que, por meio de uma rede de contatos, “cria -se” uma idéia de conexão e de continuidade entre elas.

Sob esse ponto de vista, a aparição da Virgem da Medalha Milagrosa é um fenômeno de transição, pois, por um lado possui as características dos relatos de visões para monges comuns na Idade Média, por outro lado, tornou-se uma aparição pública, forjada e divulgada pelo clero, como as outras analisadas por Gillet, especialmente La Salette e Lourdes. Vale a pena lembras que, neste caso o seu caráter público - marcado pela transmissão da mensagem de Nossa Senhora aos homens por meio da Medalha Milagrosa - não está no fenômeno em si, mas no empenho do clero em difundi-la. Dessa forma, apesar de possuir características bastante distintas das duas outras aparições mencionadas, ela acaba por ser incluída no modelo de aparições do século XIX por historiadores como Albert Lorca, que enfatiza apenas sua dimensão pública e o reconhecimento do Vaticano.

Se as semelhanças entre as manifestações não devem ser ignoradas, devemos lembrar, no entanto, que elas se tornam mais evidentes devido à construção realizada destas aparições pelo clero - Rue du Bac, Lourdes e La Salette - como um fenômeno milagroso único presente na Franca neste período. Assim, inclusive a aparição da Medalha Milagrosa, em que a mensagem é privada e transmitida para uma monja, tornase pública pela existência de uma rede dedicada a "causa mariana”36.

Esse caso nos chamou a atenção para dois aspectos importantes a respeito das aparições: os elementos simbólicos que a compõem - e que estão inseridos em um

\footnotetext{
${ }^{36}$ As aparições de Lourdes e La Salette também possuem muitas diferenças. Em Lourdes a ênfase encontra-se no milagre, Maria aparece como uma figura doce e bondosa. Já em La Salette são os elementos escatológicos que se sobressaem, a Virgem 'e uma figura ameaçadora. Tanto que, embora atualmente o Santuário de La Salette seja muito menos visitado que o de Lourdes, nas aparições brasileiras as referencias a La Salette como fenômeno inaugural são comuns. Isso ocorre devido à centralidade da escatologia nas manifestações contemporâneas. Já Lourdes, embora citada, nunca e mencionada como a aparição que da inicio a esse tipo de fenômeno.
} 
imaginário de longa duração - e o papel da Igreja em relação a elas. Ambos são centrais para a constituição da legitimidade do fenômeno. A atuação Igreja insere esta manifestação no novo modelo instituído a partir do século XIX. É interessante observar que esta aparição é constantemente mencionada nos Cenáculos de aparições de Nossa Senhora no Brasil, como no caso de Jacareí, sendo a aparição com transmissão de mensagem mais antiga mencionada nas manifestações contemporâneas ${ }^{37}$.

Apesar das menções a mensagem da Virgem na Rue du Bac nas aparições de Jacareí, os participantes não estabelecem uma continuidade entre essa manifestação e as aparições da atualidade. Ou seja, apesar de suas mensagens serem citadas, ela não é considerada o fenômeno inaugural, que dá inicio a uma série de manifestações semelhantes. Esse papel é na verdade atribuído às aparições de Fátima e La Salette, elas são consideradas inaugurais deste tipo de fenômeno, especialmente devido a seus elementos escatológicos, como observaremos no quarto capitulo, dedicado à importância da escatologia nas mensagens de Nossa Senhora.

Assim, embora o clero tenha conseguido fazer com que ela se tornasse uma manifestação de grande devoção, os participantes das aparições contemporâneas não atribuem a mesma importância a ela quanto aquela atribuída aos fenômenos em que a dimensão escatológica é central, como Fátima e La Salette.

Dessa maneira, existe um descompasso entre as afirmações dos historiadores e as falas dos participantes com relação ao que é considerado como "fenômeno inaugural”. Enquanto os historiadores colocam as três manifestações francesas como inaugurais, para os fiéis apenas La Salette é percebida desta forma. Isso ocorre devido à centralidade atribuída pelos devotos a determinados elementos simbólicos das aparições que não estão presentes na visão da medalha milagrosa e na aparição de Lourdes, especialmente a escatologia, e que não permite a eles estabelecer uma relação de continuidade entre elas e as manifestações contemporâneas.

Nesse sentido, estas duas dimensões das aparições marianas devem ser analisadas: o papel da Igreja no apoio ou rejeição das manifestações e a composição simbólica dos fenômenos. No que se refere à simbologia, a observação dos elementos simbólicos das aparições contemporâneas demonstra, por um lado, a sua busca de legitimidade em elementos presentes nas manifestações reconhecidas do século XIX e,

\footnotetext{
${ }^{37}$ Além disso, a sua divulgação continua muito eficiente, ao menos no Brasil, em que o mês de Novembro é considerado o mês da Medalha Milagrosa, havendo a distribuição de medalhas com a mensagem da Virgem em todas as paróquias do país.
} 
por outro lado, a presença destes símbolos no imaginário católico brasileiro de longa duração. A busca de legitimidade por meio da aproximação com as aparições modernas e a continuidade dos elementos simbólicos serão objetos dos próximos capítulos. Agora devemos nos deter na centralidade da Igreja e de seus representantes na produção e manutenção destes fenômenos.

Dois aspectos deverão ser destacados: a importância dos representantes da Instituição na produção de idéias, valores e práticas sobre as aparições - importantes fontes de sua legitimidade - e a centralidade do movimento carismático na divulgação e circulação deste sistema de crenças e práticas sobre as aparições de Nossa Senhora na atualidade. Para isso partiremos dos critérios estabelecidos pelo Vaticano para a análise da veracidade das aparições. Observaremos, em seguida, que estes critérios são usados de acordo com os interesses dos analistas - para considerar os fenômenos analisados como verídicos ou não.

\section{2) A Avaliação estabelecida pelo Vaticano}

A palavra chave estabelecida pelo Vaticano, e repetida pelos sacerdotes bispos, padres, - diante das chamadas manifestações extraordinárias é "prudência”. Os representantes da Igreja devem tomar a frente dos fenômenos e analisá-los cuidadosamente. Esse é o posicionamento da teologia clássica sobre as aparições, seguindo as determinações de que todas as manifestações aparentemente sem explicação, como as aparições e os milagres, devem ser cuidadosamente analisados antes de serem aprovados.

O Vaticano estabelece critérios e procedimentos para a análise da veracidade das manifestações. No caso das aparições, elas não são aprovadas ou condenadas oficialmente, mas apenas permitidas como “objeto de fé humana”, pois rende homenagem a Maria, mãe de Jesus. Ou seja, elas não são concebidas como dogmas ou obrigações de fé, sendo que a Igreja deixa a critério de cada católico a devoção e crença nas aparições marianas. É preciso esclarecer que estamos nos referindo às aparições que já foram avaliadas segundo os critérios que descreveremos a seguir, ou seja, as aparições autorizadas.

Entretanto, a grande maioria das aparições é rejeitada pela Igreja, pelo bispo local - primeiro responsável pela análise da veracidade do caso. E, se por um lado a Igreja deixa a critério de cada cristão a crença nas aparições autorizadas, por outro lado, 
no caso das aparições não autorizadas - consideradas não verídicas - os representantes da Igreja podem ser extremamente ferozes no seu combate, como no caso citado de Jacareí. Vale a pena reforçar que, até o momento, estamos descrevendo o ponto de vista oficial, pois, quando observamos diretamente os fenômenos podemos constatar que eles são muito mais complexos do que estabelecido pelas posições doutrinais.

Tanto defensores como opositores das aparições se utilizam dos critérios estabelecidos pelo Vaticano para fundamentar e legitimar suas posições, atribuindo-lhes significados específicos. Isso foi observado tanto no plano teológico, em que analisamos o uso dos critérios pelo teólogo René Laurentin, quanto no plano local, nas relações estabelecidas entre os devotos das aparições - vidente e grupos de apoio - e os sacerdotes locais. Veremos isso com mais detalhes quando analisarmos o caso de Jacareí. Ou seja, os critérios são importantes e são sempre utilizados, mas são ressignificados de acordo com as crenças e interesses dos atores e grupos envolvidos.

A posição do bispo é extremamente importante na avaliação das aparições, pois o parecer sobre as manifestações é realizado por ele. Nesse aspecto, a análise das aparições difere das canonizações, pois, os processos de canonização são conduzidos e avaliados pelo Vaticano. Nas canonizações o Papa assume oficialmente, enquanto no caso das aparições o Vaticano estabelece apenas os critérios: o julgamento de cada caso é responsabilidade do bispo. Cabe enfatizar que a maior parte dos casos, como Jacareí, é rejeitada localmente pela diocese, não chegando a ser alvo de análise por parte das instâncias mais altas.

Voltemos, então, aos critérios de julgamento da veracidade das aparições. De acordo com as recomendações da Comissão para a Doutrina e a Fé, o principal aspecto a ser analisado é a ortodoxia da mensagem transmitida pela Virgem, ou seja, o seu conteúdo, que deve estar de acordo com a doutrina católica. As mensagens são consideradas, pela teologia oficial, como uma forma de profetismo, sendo o "profeta aquele que atualiza os desejos divinos”. Trata-se de uma atualização da revelação divina, ou seja, uma aparição não deve trazer nada de novo no que se refere à doutrina católica, pelo contrário, deve apenas reforçar o que já existe. Assim, é justamente a adequação entre as mensagens transmitidas por Nossa Senhora e a doutrina católica o primeiro ponto a ser analisado pelos sacerdotes. As acusações de falsidade, na maior parte dos casos estão calcadas nesta justificativa, ou seja, os responsáveis pela análise procuram demonstrar que o conteúdo das mensagens não está de acordo com a doutrina 
da Igreja Católica. Ou seja, buscam elementos para deslegitimar a aparição demonstrando a sua “inconsistência” em relação à doutrina.

O segundo critério a ser analisado é a autenticidade do movimento coletivo que se forma em torno destes eventos, com foco nas preces e conversões decorrentes dele. Estamos novamente no plano da adequação à ortodoxia, pois, o que deve ser analisado é a proximidade com os rituais oficiais do catolicismo, se não se trata de um movimento baseado em "exageros”, em manifestações e práticas rituais que não possam ser aceitas pela doutrina católica. Sob esse aspecto, trata-se de uma análise ainda mais subjetiva do que a primeira, pois envolve o grupo de pessoas ligadas à aparição e suas práticas, bem como o posicionamento teológico do bispo em relação a essas práticas. Dessa forma, embora seja importante a explicitação dos critérios estabelecidos pelo Vaticano, também não podemos deixar de lado a sua utilização pelos atores e grupos envolvidos no contexto das aparições, sendo ela central para a aceitação ou rejeição das manifestações.

Isso fica claro em um texto escrito pelo Pe Laurentin, notório defensor das aparições de Nossa Senhora do qual trataremos mais adiante, em que ele aborda os critérios de avaliação estabelecidos pelo Vaticano. Quando menciona o "movimento coletivo que se forma em torno destes fenômenos”, fala, por um lado, das pessoas de “má fé” que podem se aproveitar da ingenuidade dos católicos, atentando, pois, para o cuidado que os avaliadores devem ter diante destas situações. Em suas palavras, trata-se de um fenômeno ambíguo, podendo ser "sujeito de ilusões e seduções, sobretudo no caso de fenômenos locais, sendo função do magistério exercer uma crítica sobre esses movimentos e reações". Assim, embora a mobilização de pessoas gerada por uma aparição seja considerada importante para a sua autenticidade, ela deve ser tutelada pelo clero, para evitar “desvios” da ortodoxia católica.

Entretanto, por outro lado, o autor também menciona o rigor, considerado excessivo, com que os avaliadores têm julgado as aparições, colocando a grande maioria delas como indigna de fé. Neste ponto ele, como defensor deste tipo de manifestação embora se afirmando ciente da falsidade de vários deles - conclama a população a defender os fenômenos que consideram verdadeiros, a se engajar no seu processo de discernimento e julgamento.

Assim, o autor oscila entre a defesa da autenticidade destas manifestações coletivas e a suspeita de manipulação delas por pessoas de "má fé”, transitando entre uma concepção da fé autentica do povo e uma outra concepção que o considera como 
manipulável, defendendo a tutela da Igreja sobre ele, de forma a defendê-lo de pessoas mal intencionadas, que possam querer aproveitar-se da sua "inocência”, como é o caso de alguns videntes "falsos". Esse fator nos remete novamente para as situações específicas, sendo que a classificação desse movimento coletivo como autêntico ou como de "má fé” depende dos atores e grupos envolvidos e das relações estabelecidas entre eles - do bispo, dos sacerdotes, dos grupos de apoio, do vidente, entre outros.

O terceiro aspecto a ser julgado é a postura dos videntes. Em todos os casos de aparições, aceitas ou rejeitadas pela Igreja, os videntes foram insistentemente interrogados, observados, vigiados, pelas autoridades católicas ou por pessoas designadas por ela, como médicos e psicólogos. Trata-se de analisar dois aspectos: se o vidente é mentalmente “equilibrado” e se ele está dizendo a verdade - ou se trata de um louco, charlatão ou impostor.

Ao analisar a bibliografia sobre as aparições reconhecidas pela Igreja Católica percebemos que a postura adotada pelo vidente, especialmente a sua relação com a hierarquia local, é central no desenrolar dos acontecimentos. De forma geral, nos casos reconhecidos, como o caso de Lourdes, a vidente adotou uma postura de obediência à hierarquia católica local, tornando-se inclusive, religiosa carmelita. Ruth Harris, em seu livro sobre as aparições de Lourdes, demonstra a importância desta postura obediente e submissa de Bernadete no processo de aceitação desta manifestação pela Igreja. Ela é, inclusive, posteriormente canonizada, tornando-se Santa Bernadete, representando até os dias de hoje um “ideal” de santidade e obediência no catolicismo. A postura do vidente é decisiva para o parecer da hierarquia católica sobre o fenômeno. Nesse sentido, quando uma aparição é considerada “digna de fé" um dos aspectos constantemente destacado por seus teólogos e analistas é o chamado "testemunho de vida” do “escolhido de Nossa Senhora”. Ou seja, quando a vida de um vidente após a aparição é considerada exemplar, quando ele se torna religioso ou religiosa, como no caso citado de Bernadette, são elementos que contribuem para a aparição ser considerada verídica.

O quarto elemento importante é a análise dos milagres decorrentes da aparição. Se existem milagres comprovados a aprovação de uma aparição é bastante facilitada. Entretanto, a análise de milagres deve passar pelo Vaticano, por análises médicas e científicas que possam afirmar que o evento não tem explicação “natural”, ou seja, que não pode ser explicado cientificamente, possuindo uma dimensão sobrenatural. Assim, a comprovação da existência de um milagre passa por várias instâncias, que na 
maioria das vezes são ainda mais demoradas do que o julgamento realizado pelo bispo, pois não depende apenas do clero, mas de análises de cunho científico que ultrapassam as suas funções doutrinárias. Atualmente um fato apenas é reconhecido como milagroso quando não possui explicação científica, e por isso, cada caso, como uma cura, por exemplo, deve ser analisado e reconhecido como tal por um corpo de cientistas, sendo que só então a Igreja o aceita como um milagre ${ }^{38}$.

No caso das aparições contemporâneas no Brasil esse aspecto é praticamente excluído da avaliação devido às dificuldades que implicam a análise de um evento supostamente milagroso pela hierarquia do catolicismo, e também devido a se tratarem de eventos recentes. As aparições que possuem milagres reconhecidos são as mais antigas, aquelas já foram submetidas a todas as exigências e análises necessárias para o seu reconhecimento.

Vale a pena destacar que a aparição que possui o maior número de milagres associados a ela é Lourdes - aproximadamente sessenta - mas, para se atingir esse número foi instalado no Santuário um "escritório de análise médica dos milagres”, que verifica cada um dos casos relatados pelos peregrinos como milagrosos. Houve um verdadeiro investimento dos administradores do Santuário no aspecto milagroso das aparições, investigando detalhadamente cada relato a partir de critérios que ultrapassam o campo religioso, a legitimação de um milagre encontra-se na ciência, na medicina, e não em critérios religiosos. A justificação científica de eventos milagrosos foi inaugurada no Santuário de Lourdes, que sistematizou os critérios médicos de análise.

Entretanto, devemos destacar que essas características estão relacionadas com o reconhecimento oficial de um milagre por parte do Vaticano, pois, para os peregrinos das aparições o milagre é uma realidade, uma presença cotidiana, independente do posicionamento oficial da Igreja. Os relatos de pessoas que receberam a graça do milagre são comuns em eventos desse tipo, e é em sua busca que muitas pessoas realizam a peregrinação. Porém, como já dito, neste momento nos deteremos apenas nos critérios estabelecidos pelo Vaticano para o julgamento da veracidade das aparições marianas, e não nas diferentes formas, interpretações e utilizações dadas a eles por parte dos muitos atores envolvidos nesse tipo de evento.

\footnotetext{
${ }^{38}$ Com os avanços científicos do ultimo século, o reconhecimento de um fato como milagroso é cada vez mais raro, pois, muitos dos supostos milagres podem ter explicações científicas, o que exclui de antemão seu caráter sobrenatural, extraordinário.
} 
Importa destacar que cada um dos critérios pode ser interpretado e utilizado de diferentes maneiras em casos específicos. Ou seja, os defensores e opositores das aparições os utilizam para legitimar ou deslegitimar os fenômenos. Eles servem como um roteiro para os bispos e para os analistas, porém, são reformuladas e resignificadas de acordo com os posicionamentos, as relações e negociações que são estabelecidas pelos atores envolvidos no evento - defensores, opositores, bispos, sacerdotes, videntes - como demonstraremos no caso da aparição de Nossa Senhora em Jacareí e também no caso da aparição de Pontmain, analisada por René Laurentin. Ou seja, a forma de utilização dos critérios depende dos interesses e das posturas de quem os utiliza.

Antes de desenvolvermos estes debates em um plano local, devemos nos deter no plano mais "global e geral”, ou seja, nas posições adotadas pelos representantes hierarquicamente superiores da Igreja, importantes produtores de idéias e de práticas que servem como fonte de legitimidade para as aparições marianas. Dessa maneira, as crenças e práticas sobre as aparições marianas, que circulam por meio da rede descrita no capítulo anterior, tem origem em atores situados nas altas instâncias da Instituição Católica.

Começamos analisando a importância do Pe Laurentin, procurando demonstrar como esse teólogo desenvolve argumentos em defesa das aparições de Nossa Senhora que se utiliza dos critérios estabelecidos pelo Vaticano. Notamos que na maior parte dos casos ele busca aproximar sua análise do que é estabelecido pela Comissão da Doutrina e da Fé para comprovar a legitimidade de uma manifestação.

\section{3) Rene Laurentin e a defesa das aparições de Nossa Senhora}

Não podemos dar início aos debates teológicos sobre as aparições marianas sem mencionar o seu mais notório defensor: Padre René Laurentin. Ele é um dos mais iminentes teólogos marianos da atualidade, sendo defensor não apenas de uma aparição de Nossa Senhora, mas de inúmeras delas, possuindo vários livros publicados sobre diferentes manifestações. Desde o início da segunda metade do século XX ele pesquisa e escreve sobre as aparições da Virgem pelo mundo, sendo esta a sua especialidade.

A sua importância, inclusive, vai além do campo teológico, pois suas idéias e teorias circulam pelo mundo católico, em grande parte devido a sua proximidade com o movimento Renovação Carismática Católica. A grande maioria de suas obras está traduzida para o inglês - tendo grande penetração nos Estados Unidos, berço da RCC e 
sede da coordenação internacional do movimento ${ }^{39}$, sendo disseminada entre os carismáticos por todo o mundo. Além disso, o teólogo também realiza palestras sobre Nossa Senhora, sendo, atualmente, um dos mais importantes divulgadores da devoção às manifestações extraordinárias de Nossa Senhora - aparições, locuções e milagres.

A antropóloga Elisabeth Claverie, em seu livro sobre as aparições de Medjugorje (2003), destaca que René Laurentin sempre esteve na contra corrente da teologia dominante, estabelecendo uma defesa da figura de Nossa Senhora no catolicismo. Ele faz a apologia das aparições marianas desde antes do Concílio Vaticano II, momento em que essa escolha representava um enfrentamento a outras correntes de espiritualidade, e continuando na fase pós-conciliar, em que a corrente que defendia o marianismo foi objeto de vários ataques. Laurentin enfrentou estas batalhas por meio da organização de dossiês sobre as aparições do século XIX, a princípio, estendendo-se a outras manifestações em seguida, como Fátima e Medjugorje.

O ponto de partida do teólogo, nos anos sessenta, foi a aparição de Lourdes, sobre a qual montou um enorme dossiê, publicado em doze volumes, nos quais busca demonstrar a veracidade das aparições por meio do que ele denomina "provas". Essa metodologia de trabalho de Laurentin é repetida na análise de outras manifestações, sobre as quais também organiza dossiês em que busca comprovar a veracidade dos fenômenos. Sob esse aspecto, utiliza-se de uma metodologia positivista, fazendo um grande levantamento de "evidências" sobre cada evento para demonstrar a sua autenticidade. Trabalha, segundo Claverie, em um registro característico da “modernidade”, adotando um modo de enunciação de tipo jurídico/judiciário, começando, de modo geral, pela comprovação da “credibilidade” dos videntes. Nestes "processos", ao enfocar a probidade dos videntes, as questões giram em torno de três eixos principais: Se os videntes mentem ou falam a verdade - são pessoas dignas de confiança? -, se eles têm sanidade mental ou não e se não estão sendo manipulados. Com base na análise destes dados ele junta elementos que, na sua perspectiva, comprovam a autenticidade das manifestações.

Além das publicações sobre a aparição de Nossa Senhora em Lourdes - doze volumes com documentos, entrevistas, originais dos interrogatórios, descrição detalhada

\footnotetext{
${ }^{39}$ Como explicado no primeiro capítulo, a RCC possui uma organização hierárquica, sendo que no topo desta hierarquia encontra-se a coordenação internacional, nos EUA. Este país sempre teve grande importância no movimento, sendo não apenas seu local de nascimento, mas também responsável pela origem e divulgação de idéias, práticas e crenças da Renovação Carismática.
} 
dos milagres, a personalidade da vidente Bernadette, entre outros ${ }^{40}$ - Laurentin também produziu obras sobre as aparições de Pontmain - três volumes de documentos -, La Salette - um grande volume com os documentos originais sistematizados pelo historiador Joan Stern, inclusive as publicações presentes na mídia da época -, Rue du Bac - dois volumes de documentos e dois volumes de características da personalidade “santa” da vidente Catherine Labouré - aparições marianas acontecidas na França no século XIX e aprovadas por diferentes bispos.

No entanto, Laurentin não se detém apenas nas manifestações reconhecidas pelo Vaticano, ou ao século XIX na França, sendo que, desde a década de oitenta o autor é um iminente defensor da aparição de Nossa Senhora na Vila de Medjugorje, tendo publicado vários livros, desde que se iniciaram as aparições, em 1981, buscando demonstrar a sua veracidade. Esses são apenas alguns exemplos da extensa obra dedicada às manifestações de Nossa Senhora por René Laurentin.

Vale a pena destacar que este teólogo se utiliza de uma aparelhagem que possa ser recebida no mundo da crítica científica - onde não é lido, mas onde se inspira para produzir e trabalhar seus dados - coletados, demonstrados e analisados como “provas científicas”. Assim, traz gráficos, tabelas, pareceres de especialistas - médicos, psicólogos, historiadores - utilizados como comprovações. Por fim, monta um processo a fim de garantir a credibilidade de seu aparelho demonstrativo.

A causa mariana defendida por ele é, pois, embasada em dados. No entanto, ela também representa uma posição mais geral do autor sobre o tratamento dado aos chamados “eventos extraordinários” pela Igreja Católica na atualidade, considerando que esses fenômenos ou são deixados de lado pelo catolicismo no mundo contemporâneo, ou tratados com desconfiança. Importa destacar que quando ele se refere à Igreja está na verdade se referindo a corrente teológica majoritária no catolicismo atual, que defende uma postura de prudência e análise diante das manifestações “milagrosas” - sejam elas curas, milagres ou manifestações de Maria.

Dessa maneira, Laurentin estabelece um debate interno ao catolicismo, em que questiona o empenho dos bispos em analisar as aparições e a postura da corrente teológica majoritária na Igreja, acusada de colocar os fenômenos extraordinários em segundo plano. A sua frase “A Igreja não gosta do milagre”, presente na introdução do “dicionário do extraordinário na Igreja Católica”, representa bem sua posição.

40 Essa aparição foi a mais exaustivamente descrita pelo autor, sempre no intuito de demonstrar as evidências da sua veracidade. 
O autor parte de casos específicos de aparições para defender uma posição mais geral sobre as manifestações marianas e os fenômenos extraordinários. Analisamos os argumentos utilizados por Laurentin para defender a veracidade das aparições. A partir da leitura de algumas de suas obras - sobre a aparição de Lourdes, Pontmain, La Salette e Medjugorje, além de sua introdução ao Dicionário do Extraordinário na Igreja Católica - pudemos perceber alguns padrões comuns em seus argumentos. Partiremos dos dados específicos utilizados por ele em defesa destas manifestações, para demonstrar sua "causa mariana” e sua defesa do "extraordinário" no catolicismo. Constatamos que o teólogo se utiliza dos critérios estabelecidos pelo Vaticano como fonte de legitimidade para as manifestações, mas usa também argumentos que fazem sentido para os devotos, mesmo que não sejam oficialmente aceitos pela Instituição.

Antes, importa destacar que René Laurentin é conhecido por jamais combater ou sequer pronunciar-se contra qualquer aparição de Nossa Senhora. Entretanto, isso não significa que ele considere toda e qualquer manifestação como verídica, simplesmente existem algumas que ele não comenta, sendo justamente o seu silêncio um sinal de sua descrença, mas que não é jamais manifestada em seus livros ou artigos. O exemplo mais claro disso refere-se à aparição de San Sebastian de Garabandal, durante a década de sessenta na Espanha. Essa foi uma das aparições que mais atraiu peregrinos durante a segunda metade do século $\mathrm{XX}$, mas também uma das mais fortemente combatidas pelo bispo da localidade, apoiado por representantes do Vaticano, que chegaram a proibir a realização de missas no vilarejo entre a década de sessenta e oitenta deste século. Laurentin, que no período já escrevia sobre aparições marianas, nunca se manifestou sobre Garabandal. Dadas as dimensões atingidas por esta manifestação, tanto no que se refere ao número de peregrinos, quanto a enorme polêmica estabelecida entre sacerdotes e teólogos ao seu redor - alguns a defendem ferrenhamente até os dias de hoje, mencionando um “complô” de algumas instâncias da Igreja em reprimir esta manifestação - chega a ser surpreendente que Laurentin nunca tenha escrito sequer uma linha sobre San Sebastian de Garabandal ${ }^{41}$.

\footnotetext{
${ }^{41}$ Esta manifestação ocorreu na década de sessenta, não houve a formação de santuário na localidade, que eventualmente recebe ainda algum peregrino, devido à importância atribuída a ela por setores da RCC nos EUA, e mesmo mundialmente. Apesar de praticamente extinta continua a ser uma referência para as aparições da atualidade, inclusive no Brasil. Desde nossa pesquisa de mestrado sobre a RCC as menções a essa manifestação são recorrentes na fala dos pesquisados, carismáticos e/ou freqüentadores de aparições.
} 


\section{1) Laurentin e a defesa das aparições de Nossa Senhora}

A leitura das obras de Laurentin sobre as aparições de Nossa Senhora nos permitiu sistematizar os argumentos utilizados por ele em defesa destes eventos. Cada obra é constituída por uma série de documentos que buscam comprovar a veracidade de uma determinada aparição, sendo que a sua leitura chega a ser cansativa, pela grande quantidade de "evidências” que vão se acumulando ao longo dos textos.

O autor constrói sua argumentação em defesa das aparições utilizando-se, em cada caso, de dados que se aproximem dos critérios adotados pela Igreja, para demonstrar a sua veracidade. Utilizaremos como exemplo a análise realizada por ele da aparição de Pontmain.

No caso de Pontmain o número de provas recolhidas na época da manifestação foi escasso, e não houve milagres comprovados, sendo que o autor se apega em dois elementos para comprovar a sua veracidade: a ortodoxia da mensagem e principalmente o "testemunho de fé" representado pela vida dos videntes após as visões.

No que se refere à ortodoxia da aparição, houve apenas uma manifestação de Nossa Senhora, sem a transmissão de mensagens aos videntes. Então, o autor descreve sua figura, dizendo que ela aparece chorando, muito triste, de uma tristeza indescritível. Ele gasta várias páginas de sua obra na descrição da imagem da Virgem. Laurentin busca estabelecer uma relação de proximidade entre a imagem da aparição de Pontmain e a imagem legítima de Nossa Senhora das Dores. A “tristeza indescritível” da Virgem mencionada por Laurentin é somente comparável a de uma mãe que acabou de presenciar a morte de seu filho. Dessa maneira, quando associa as características de Nossa Senhora na aparição de Pontmain com a imagem de Nossa Senhora das Dores amplamente difundida no catolicismo em geral - procura transferir o valor da imagem consagrada no catolicismo para essa aparição de pouca divulgação, que, apesar de reconhecida pelo Vaticano, permanece obscura.

A associação da imagem da Virgem com a figura de Nossa Senhora das Dores é um elemento recorrente nas suas aparições, sendo que em muitos casos ela aparece chorando - como em Jacareí e em Medjugorje. Este sofrimento está relacionado à sua maternidade, como analisaremos posteriormente - ela é a mãe da humanidade, e sofre pelos pecados cometidos pelos homens. Neste ponto devemos reter a utilização desta associação pelo Pe Laurentin, a fim de legitimar as aparições de Pontmain. 
Outro elemento utilizado pelo autor é a vida dos videntes após a aparição de 17 de Janeiro de 1872. Esse é o aspecto a que o autor mais se detém, dedicando a ele parte significativa de sua obra. Segundo ele, todos os videntes tiveram uma vida que pode ser considerada como testemunho de fé. Ou seja, os videntes levaram uma vida de acordo com os padrões considerados corretos pelo catolicismo.

Dois processos de avaliação foram abertos pela diocese local sobre a aparição de Pontmain, ambos obtendo parecer favorável. O primeiro logo após as manifestações, em que as quatro crianças foram interrogadas separadamente, sendo que o analista encontrou "coerência e boa fé” em seus relatos, elaborando um relatório favorável para o bispo. O segundo processo ocorre em 1918, quando as testemunhas ainda vivas foram ouvidas e os quatro videntes examinados por professores de escolas de medicina, novamente interrogados separadamente e colocados à prova. Novamente, nas palavras do autor, "tudo ia bem. Pontmain continuava um lugar de fervor. Não havia existido nem epidemia de visionários, como em Lourdes. Tudo estava claro, os videntes não tinham nenhum segredo. Todos tinham entrado na vida adulta sem visão nem êxtase, tinham seguido uma vida cristã exemplar" (77).

A colocação anterior do autor aponta dois aspectos importantes de sua análise: por um lado, o enfoque na vida e na postura dos videntes para demonstrar a “santidade” desta manifestação. Por outro lado, a relação entre a aparição de Pontmain e duas outras aparições ocorridas na França no mesmo período: Lourdes e La Salette, ambas também reconhecidas pelo Vaticano.

Começaremos pela vida dos videntes. O próprio autor admite que a característica central em Pontmain seja a fidelidade cristã dos videntes, pois dois dos principais videntes tornaram-se padres, dedicando a vida à Igreja. É sobre eles que Laurentin se centra, demonstrando os seus "atos de fé cristã”, no intuito de demonstrar que a vida dos videntes pode servir como prova da veracidade de uma manifestação. Já no que se refere à vida dos outros dois videntes Laurentin é bem mais econômico em seus argumentos, dedicando apenas quatro linhas a Françoise Richer - que levou uma vida obscura, segundo ele - e pouco mais que isso a Augustine Boitin, embora fazendo questão de enfatizar que ela se converteu na hora da morte. Dessa maneira, nada na vida dos videntes depõem contra eles, pelo contrário, serve como prova de que a Virgem realmente lhes apareceu, pois levaram uma vida dedicada a Igreja, como, na sua opinião, é esperado de alguém que tenha estado em contato com Nossa Senhora. 
Voltando a citação anterior, o autor também busca a atribuir valor a Pontmain estabelecendo um contraponto com outras duas aparições francesas contemporâneas a ela: Lourdes e La Salette, especificamente no que diz respeito à postura dos videntes e aos eventos que sucederam ao período das aparições. Isso por que, no caso de La Salette uma das videntes, Melanie, depois de adulta afirmou continuar tendo visões da Virgem, publicando inclusive um livro com as "novas" revelações de Nossa Senhora. Essas novas visões foram severamente condenadas pela Igreja, sendo a vidente acusada de "má fé” e de querer tirar proveito delas. Já no caso de Lourdes ocorreu a proliferação de visionários após as revelações feitas para Bernadette, ou seja, várias pessoas afirmavam ter visões da Virgem na grota de Lourdes. Todos eles são considerados falsos e foram reprimidos pelos representantes da Igreja, reconhecendo-se apenas Bernadette como a vidente verdadeira.

Laurentin se utiliza desses eventos turbulentos e reprimidos pela Igreja para demonstrar a "santidade" dos videntes e do episódio de Pontmain. Lá nunca houve problemas com as crianças nem o surgimento de “falsos” visionários, pelo contrário, duas delas tiveram vidas consideradas exemplares após a manifestação - demonstrando, para ele, a intervenção da Virgem em suas vidas - e mesmo os dois videntes que não se tornaram religiosos mantiveram-se na “obscuridade”, sem tentar se aproveitar dos eventos anteriores, como ocorreu com Melanie, a vidente de La Salette.

O teólogo estabelece uma inter-relação constante entre os três episódios Lourdes, La Salette e Pontmain - não apenas nestas obras, mas em várias outras. Esse fato tem várias explicações, uma delas é que elas são próximas geograficamente e simultâneas - todas ocorrem na França na segunda metade do século XIX. Além disso, todas as três recebem parecer favorável da Igreja. O autor possui exaustivos dossiês sobre cada uma delas, sendo um profundo conhecedor dos eventos. Assim, Laurentin, ao estabelecer a comparação com estes dois santuários marianos importantes e Pontmain, busca atribuir valor para esta manifestação - em que o "testemunho de vida" dos videntes e a tranqüilidade dos episódios são ainda maiores do que os existentes nas outras duas aparições ${ }^{42}$.

\footnotetext{
${ }^{42}$ A utilização de aparições reconhecidas para legitimar uma manifestação mais recente ou ainda não reconhecida é comum na abordagem do autor. O autor realiza este processo em sua argumentação em defesa da aparição de Medjugorje, iniciada na década de oitenta do século XX. As aproximações com as aparições reconhecidas, bem como o esforço em demonstrar a probidade dos videntes são recorrentes em suas obras sobre as manifestações de Nossa Senhora nesta vila. Inclusive, vale a pena mencionar a existência de uma forte polêmica sobre Medjugorje, que envolve dois dos mais destacados teólogos marianos da atualidade: René Laurentin, que defende ardentemente a veracidade deste fenômeno e
} 
Entretanto, mesmo centrando-se na vida e na coerência dos videntes, o autor não abandona outras evidências que ajudem a legitimar essa aparição. Já mencionamos a aproximação da imagem da Virgem a Nossa Senhora das Dores. De forma semelhante também os milagres de Pontmain são referidos por ele. A existência de milagres comprovados conta muitos pontos na produção da legitimidade de uma manifestação e, embora no caso de Pontmain não existam milagres comprovados, Laurentin faz uma lista de milagres atribuídos a Nossa Senhora de Pontmain, com a ressalva de que se trata somente de uma lista de relatos de pessoas que receberam as graças, mas que não foram comprovadas. Em suas palavras "o que resta são histórias tocantes que marcaram vidas, vocações, famílias, que trouxeram a adesão dos corações à presença de um Deus poderoso e benfeitor" (60) Embora exista a ressalva, a lista está presente entre seus dados, ou seja, mesmo sem o reconhecimento oficial ela é considerada importante, pois “marcou vidas e famílias”. Então, mesmo que o autor não centralize sua argumentação sobre os milagres, por eles não serem reconhecidos e, portanto por não aportarem tanto valor e credibilidade para o evento, ele os acrescenta a sua lista de dados.

Isso ocorre devido às crenças do próprio autor, que são compartilhadas por uma série de devotos, ou seja, o que os fiéis consideram como milagre não é exatamente o estabelecido pela Igreja - que exige uma comprovação do caráter sobrenatural de um fato para considerá-lo como um milagre. Para a maioria dos fiéis o simples relato de uma graça recebida é suficiente para dar-lhe a característica milagrosa. Assim, mesmo não sendo “comprovadas”, as histórias de graças recebidas, especialmente quando organizadas na forma de evidências, contribuem, mesmo que em grau menor que os milagres reconhecidos, para a legitimidade da aparição.

Neste ponto importa destacar a utilização dada pelos devotos para os estudos de Laurentin. Muitos dos peregrinos das aparições, especialmente os carismáticos e os participantes de grupos de apoio, conhecem as idéias e as “comprovações” realizadas pelo teólogo sobre as aparições. Essas justificativas são importantes para eles, especialmente aqueles que possuem um vínculo maior com a instituição, que se apóiam nelas para justificar sua crença diante das pessoas que não crêem nas manifestações de Nossa Senhora, principalmente no âmbito do catolicismo. Segundo esses peregrinos, eles não precisam das provas elaboradas por Laurentin, pois eles já crêem nas aparições, mas as utilizam para justificar sua crença diante daqueles que não crêem.

Phillipe Bouflet, que o condena, taxando os videntes, bem como os franciscanos que os apóiam, de charlatões. 
Dessa forma, a inserção dos milagres não reconhecidos da aparição de Pontmain pode ser compreendida. Para os que crêem nas aparições não é preciso a comprovação dos milagres, apenas o seu relato basta, pois eles já acreditam - assim como o próprio teólogo. Entretanto, a prova nos moldes científicos importa para ambos - fiéis e teólogo - como forma demonstrar a veracidade das aparições diante daqueles que não crêem nelas.

Laurentin, então, trabalha com os dois tipos de registro. Por um lado, cria dados e tabelas, a metodologia positivista, que legitima as aparições diante dos crentes e descrentes - e que é aproveitada como argumento da sua veracidade pelos que crêem nas aparições diante dos descrentes - e, por outro lado, os simples relatos, que são suficientes para os devotos, pois eles têm fé, por isso não precisam de “provas”.

Ambos estão presentes no discurso dos participantes. Quando desejam demonstrar a veracidade das manifestações se utilizam de argumentos de base científica - geralmente quando desejam “convencer” seus interlocutores. Já nas conversas entre eles relatam milagres e curas, sem preocupação com provas.

Dessa maneira, notamos, por um lado, o uso dos critérios de acordo com as crenças e interesses do teólogo, atribuindo valor aos eventos pela demonstração de seu caráter extraordinário, por meio de termos e de um vocabulário reconhecido pelos participantes, por aqueles que já crêem nestes eventos. Por outro lado, Laurentin também produz “provas”, usa de uma metodologia e de dados “científicos”, importantes para a defesa destas manifestações entre os que não crêem nas aparições, como alguns setores e grupos da Igreja Católica.

\section{2) Laurentin e seus interlocutores: o lugar do "extraordinário" na Igreja}

O extraordinário é considerado por Laurentin como sinônimo de milagre, sendo que, em suas palavras, "não há milagre constante”, assim, todas as manifestações que não tenham um caráter cotidiano e ordinário podem ser consideradas como “extraordinárias”, ou como "milagres”. Nesta categoria se encaixam as aparições de Nossa Senhora, as revelações - mensagens, vozes, odores - realizadas para os seres humanos, bem como os eventos considerados “inexplicáveis”, chamados genericamente de milagres, como curas, tanto de caráter físico como “espiritual”.

Atualmente o reconhecimento de um milagre pela Igreja apenas ocorre mediante a comprovação científica deste, ou seja, devem existir provas de que o evento 
não possui uma explicação natural, e somente então será atribuída uma dimensão sobrenatural a ele, podendo ser classificado como milagre. Assim, há uma grande burocracia estabelecida pela Igreja para o reconhecimento dos milagres, que dificulta cada vez mais a classificação de um evento como milagroso ${ }^{43}$.

Esse rigor é questionado por Laurentin, que possui uma concepção de milagre menos rigorosa e burocrática, como observado em relação à aparição de Pontmain. O simples fato de existir relatos de milagres, que, segundo ele trouxeram graças ou bem estar aos atingidos, já é suficiente para demonstrar a presença do sobrenatural naquele local. Ou seja, não é necessária a comprovação da presença da intervenção divina, os relatos de graças bastam para demonstrar a sua presença. Laurentin oscila entre a importância da comprovação, de caráter natural e científico realizada em suas análises das aparições, e a centralidade da crença, considerada suficiente para demonstrar a presença do divino, contrapondo-se aos critérios oficialmente estabelecidos.

A dupla posição do autor fica ainda mais evidente em sua obra "Vrais et Fausses Apparitions dans l'Église”, em que discorre sobre as verdadeiras e falsas aparições na história da Igreja, demonstrando os critérios utilizados por ela na avaliação das manifestações marianas "extraordinárias”. Se, por um lado, discorre sobre os critérios estabelecidos, demonstrando sua importância para o bom julgamento dos fenômenos pela Igreja, por outro lado critica a posição de seus colegas sacerdotes na avaliação das aparições, responsabilizando-os pelo aumento no número de aparições rejeitadas na segunda metade do século XX. Ou seja, quando os critérios são utilizados para aprovar uma manifestação eles são valorizados pelo autor, porém, quando eles levam à reprovação dos fenômenos, fato que acontece na maioria dos casos, ele acusa os sacerdotes, especialmente os bispos, de excesso de rigor na utilização das regras.

O teólogo está de acordo com a decisão estar nas mãos dos representantes da Igreja, em suas palavras, "o papel específico da Igreja é o de julgar e criticar, autenticar ou rejeitar, para guardar os cristãos dos desvios e alienações que os ameaçam.” (196). Cita, inclusive, como exemplo disso a aparição de Nossa Senhora de

\footnotetext{
${ }^{43}$ Devemos colocar aqui uma ressalva de que, apesar de toda essa burocracia, durante o papado de João Paulo II o número de canonizações triplicou em relação ao papado anterior, fato que demonstra uma maior valorização do milagre, pois, para que ocorra uma canonização é necessário a comprovação de um certo número de milagres. Ou seja, apesar deste rigor oficial, o papado de João Paulo II abre uma brecha neste rigorismo. Abordaremos este tema a seguir, ao tratarmos da importância deste Papa para as aparições de Nossa Senhora.
} 
Lourdes, em que, segundo ele, a análise das curas por um comitê médico serviu para iluminar os casos prodigiosos.

Percebemos que para ele a importância da análise está na exaltação dos casos realmente prodigiosos. O exemplo utilizado do comitê de Lourdes é interessante, pois este comitê busca comprovar os casos miraculosos, porém, neste processo vários eventos são descartados, não sendo considerados milagres. Esse fato, ao invés de deslegitimar o poder milagroso de Lourdes, serve para reforçar a excepcionalidade do milagre. Ou seja, os casos que não são considerados como milagrosos também servem para exaltar a existência de milagres no local, aumentando a legitimidade dos casos "comprovados".

Nesse aspecto, os exaustivos dossiês realizados por Laurentin sobre as aparições são inspirados nos dossiês do comitê de análises médicas de Lourdes. Na verdade, isso não é algo surpreendente, pois autores já demonstraram que este escritório representa uma nova maneira de se analisar os eventos considerados extraordinários pela Igreja, baseado em comprovações médicas e científicas.

Vale a pena destacar que esse novo tipo de análise está relacionado com o momento em que ocorrem as aparições de Lourdes, e com o intenso debate estabelecido em torno dela, polarizando os representantes da Igreja e defensores do cientificismo na França do século XIX. Lourdes é emblema deste embate.

Neste contexto, pois, a Igreja decide utilizar métodos positivistas, e todo um aparato médico e científico para demonstrar a veracidade, o caráter sobrenatural da aparição da Virgem por meio da comprovação dos milagres. Em outras palavras, ela começa a utilizar-se dos critérios do "inimigo", neste momento representado pelo cientificismo, para legitimar algo - os milagres - que antes estava exclusivamente no plano das crenças. No período anterior ao final do século XIX a avaliação de um milagre era realizada apenas pelos representantes da Igreja, sendo somente a partir de Lourdes que profissionais de outras áreas foram considerados imprescindíveis para a definição do caráter milagroso de um evento.

Dessa forma a Igreja, por meio desse comitê, analisa os relatos de milagres a partir de métodos científicos positivistas, e os utiliza para rechaçar alguns eventos, classificando-os como “ilusões”. Entretanto, ao fazer isso, exalta e valoriza os relatos considerados verídicos, atribuindo-lhes ainda mais legitimidade.

A postura de Laurentin segue a mesma linha, pois, apesar de admitir a existência de "ilusões e exaltações" quanto às manifestações marianas, considera que a 
análise realizada pelos sacerdotes deveria servir para a legitimação destes fenômenos, que se tornariam mais valorizados a partir do parecer positivo da Igreja. Ou seja, usa os critérios estabelecidos pelo Vaticano para a defesa das aparições de Nossa Senhora.

Já quando os critérios servem para a rejeição das aparições eles são considerados "mal usados" pelos avaliadores. Na obra citada o teólogo critica a avaliação realizada por vários bispos quanto às aparições marianas. Segundo ele, há uma proliferação das aparições desaprovadas na Igreja atualmente devido ao julgamento negativo dos bispos. Em sua opinião a maioria destas manifestações não foi bem analisada, muitas vezes sendo vistas apenas “do exterior” pelos sacerdotes.

Inclusive, a intenção do artigo é analisar a proliferação das aparições desaprovadas pela Igreja nos últimos anos, sendo que Laurentin, após discorrer sobre os critérios instituídos e demonstrar a importância de sua existência, termina por concluir que a desaprovação desse tipo de manifestação tem aumentado pelo fato dos bispos não se engajarem "profundamente" em seu julgamento. Esse artigo demonstra novamente a sua posição a favor deste tipo de manifestação. Ele critica os representantes da Igreja que não estão interessados neste tipo de fenômeno, sendo esta a justificativa dada por ele para a diminuição no número dos eventos reconhecidos: o desinteresse e a descrença por parte dos sacerdotes locais ao analisarem estes fenômenos.

Essa sua postura de defensor do extraordinário na Igreja Católica está ainda mais clara no prefácio realizado por ele ao “dicionário dos milagres e do extraordinário na Igreja Católica”. Nesta introdução Laurentin afirma ser uma audácia realizar um dicionário deste tipo, pois "o extraordinário é mal visto nos dias de hoje, tanto no mundo científico como na Igreja Católica”, logo em seguida continua “a Igreja não cultiva os milagres, ela duvida, marginaliza e os dissimula como um impedimento ou interferência para a fé e os sacramentos. Ela não aplaude os milagres, mas convida a prudência, esconde-os. Os maiores milagres são mantidos escondidos pela Igreja”. Todo o prefácio tem um tom de decepção, de discordância desta postura que o autor diz ser adotada pela Igreja.

Neste texto Laurentin deixa explícita sua crítica inclusive à "Igreja” que “não gosta dos milagres”. Sua posição pró-milagres e eventos extraordinários se torna ainda mais explícita nestas passagens. Se na primeira obra ele critica os bispos e padres pelo aumento do número de aparições desaprovadas no catolicismo, neste prefácio essa reprovação se estende para toda a Igreja, acusada de não “cultivar os milagres”, e mesmo de escondê-los e marginalizá-los. 
Assim, a sua posição de defensor do “extraordinário” na Igreja Católica é clara, sendo este extraordinário tanto os chamados milagres como as manifestações de Nossa Senhora. E, para isso, não se exime em criticar seus colegas sacerdotes em suas funções de avaliadores e nem mesmo a instituição a que pertence e em nome da qual escreve. Sob esse aspecto, para Laurentin, os critérios de análise e a produção de provas sobre as aparições são formas de legitimar estes fenômenos, mas que não excluem a importância da crença, pelo contrário, considera que é a descrença dos sacerdotes fazendo "mau uso" dos critérios ou apenas não se interessando pelas manifestações extraordinárias - que leva a proliferação de aparições desaprovadas pela Igreja.

Essa postura de Laurentin encontra importantes interlocutores na instituição. Notamos em nossa análise, além de sua importância como teólogo e produtor de idéias e de justificativas sobre os “fenômenos extraordinários”, a centralidade da circulação de suas idéias e crenças entre uma rede, principalmente por seus contatos com a RCC, que possibilitam a reprodução de suas teorias sobre as aparições de Nossa Senhora por todo o mundo ${ }^{44}$. Nesse sentido, percebemos que a concepção de milagre estabelecida pelo teólogo - menos rígida do que a presente na doutrina católica -, baseada na fé, é compartilhada pelos carismáticos e também por participantes de Cenáculos Marianos.

A proximidade entre o vocabulário utilizado por Padre Laurentin e os seguidores do movimento carismático é exemplo disso. Os termos e expressões utilizados são os mesmos, bem como as justificativas para os milagres, como a presente em seu artigo sobre o aumento das aparições desaprovadas pela Igreja, é a utilização do chamado esquema de Gamaliel: "Se a empresa vem dos homens ela se autodestruirá, mas se ela vem de Deus, vocês não conseguirão destruí-la”. Ele usa este esquema pensando nas aparições de Maria, se forem invenção humana não perdurarão, porém, se possuírem um fundo divino, sobrenatural, não serão destruídas. Trata-se de uma forma de ataque aos descrentes, especialmente aos sacerdotes, que combatem algumas destas manifestações.

O próprio teólogo, apesar de formular explicações racionais, embasadas em “provas” da veracidade das aparições, ao usar o esquema de Gamaliel demonstra que o que de fato importa é a presença do divino nestes locais, sobrepondo-se a qualquer explicação humana - favorável ou contra - estas manifestações. E a presença do divino pode ser observada apenas pela presença de devotos, pela continuidade da manifestação.

\footnotetext{
${ }^{44}$ Essa rede foi descrita no primeiro capítulo, e explica a repercussão das idéias de Lauretin.
} 
Ou seja, para ele, como devoto, a fé é importante e diz muito sobre a veracidade de um evento, sobrepondo-se mesmo aos critérios científicos e racionais, como os oficialmente estabelecidos. Assim, o autor possui um grande conhecimento teológico sobre as aparições marianas e se empenha em esmiuçar especificidades de cada manifestação separadamente, porém também se identifica com os devotos, para os quais a dimensão sobrenatural do evento não precisa ser “provada”, mas sim apenas “percebida”. Ou seja, a fé deveria bastar nestes casos, e, de acordo com o esquema de Gamaliel, ela basta.

Este mesmo esquema é constantemente mencionado pelos carismáticos em relação aos fenômenos milagrosos. Em nossa pesquisa constatamos que, logo que surge um fato considerado extraordinário - como uma pessoa que afirma ter visões de Nossa Senhora - o primeiro grupo a se mobilizar para participar das manifestações são os carismáticos, que organizam excursões para o local. Eles não apenas participam, mas emitem opiniões, geralmente avaliando a veracidade ou não da manifestação, sendo que um dos critérios utilizados por eles é justamente o esquema de Gamaliel - se elas forem verídicas, consideradas como vindas “de Deus”, se manterão caso contrário não. Esse esquema justifica, inclusive, a participação em manifestações que receberam o parecer desfavorável da instituição, pois apenas o fato deles se manterem já pode o classificar como verídico para os carismáticos.

Isso ocorreu em Jacareí nos primeiros anos da aparição, quando a RCC apoiava Marcos Tadeu, mas a diocese já havia emitido parecer contra este fenômeno, que perdura até os dias de hoje. Mesmo sem o apoio da Igreja os carismáticos continuaram participando, acionaram uma importante rede de apoio e utilizaram o esquema de Gamaliel para justificar sua participação.

Outro exemplo da circulação das idéias do Padre Laurentin entre os membros do movimento carismático é demonstrado por Elisabeth Claverie em seu livro sobre as aparições de Medjugorje. Segundo ela, todos os livros desse teólogo são traduzidos para o inglês e têm grande circulação nos Estados Unidos, berço e centro de divulgação da RCC mundialmente. Assim, os carismáticos norte-americanos têm contato com as idéias de Laurentin e as divulgam pelo mundo, através de sua organização hierárquica, em que no topo está a coordenação mundial, localizada nos EUA. Por isso a semelhança nas explicações destas manifestações por ambos. Em várias situações de campo percebemos a proximidade de expressões e explicações utilizadas pelos fiéis carismáticos e as idéias de Laurentin, que se tornaram inteligíveis após a análise que fizemos da estrutura hierárquica da RCC, tendo como “cérebro” a 
RCC norte americana, muito próxima ao teólogo, que realiza palestras neste país com grande freqüência, facilitando o contato dos carismáticos norte-americanos com a sua obra.

No entanto, apesar dos carismáticos serem importantes interlocutores de Laurentin, e embora suas idéias não estejam em sintonia com as da teologia católica pós-conciliar, a devoção a Nossa Senhora e a suas aparições encontra apoio em outros setores da Igreja Católica, e aqui podemos citar especialmente a figura do Papa João Paulo II, devoto publicamente declarado da Virgem e responsável por várias ações que incentivaram a sua devoção em todo o mundo católico ${ }^{45}$.

Assim, Laurentin tem uma grande importância na defesa teológica das aparições de Maria, que repercute pelo mundo através da RCC e dos devotos de diferentes aparições. Além dele, outra figura central para a legitimação da devoção em Nossa Senhora e em suas aparições foi o próprio Papa João Paul II, que em várias atitudes apoiou e estimulou esta devoção.

\section{4) João Paulo II e as Aparições Marianas}

Se René Laurentin é o grande produtor de idéias sobre as aparições de Nossa Senhora, João Paulo II é o mais iminente devoto destes fenômenos. Laurentin produz as idéias que compõem a credibilidade das aparições, e João Paulo II, pelo seu exemplo de fé, atribui legitimidade a elas pela sua devoção.

\section{1) João Paulo II: devoto e peregrino}

Para compreendermos a relação estabelecida entre o Papa João Paulo II e as aparições de Nossa Senhora devemos nos reportar a sua infância na Polônia, país de tradição católica, momento em que a sua devoção à Virgem Maria é estabelecida e consolidada. A devoção de Karol Wojtyla a Nossa Senhora advém de sua infância, de sua criação no catolicismo polonês. Philippe Portier (2006), em seu livro "La pensée de

\footnotetext{
${ }^{45}$ É preciso dizer que Laurentin tem interlocutores específicos, que podem variar de uma obra para outra. A "igreja” na forma genérica como é utilizada por ele em alguns casos, não existe, ele está se referindo a setores específicos dentro da Igreja, principalmente a corrente teológica que se coloca contra os milagres e os sacerdotes que rejeitam a veracidade deste tipo de manifestação. Assim, seus interlocutores mudam de acordo com o livro ou artigo em questão, pois, como mencionamos no início, cada aparição possui seus defensores, mas também seus opositores. Como no caso de Medjugorje, uma das manifestações mais polêmicas da atualidade, seu interlocutor é Phillipe Bouflet, também importante teólogo mariano, que se posiciona ferrenhamente contra essa manifestação.
} 
Jean Paul II” refere-se à infância de João Paulo II, mencionando sua devoção a Maria desde muito jovem. Segundo ele, o Papa perdeu sua mãe muito cedo, e foi criado pelo pai dentro dos preceitos do catolicismo, participando diariamente da missa e das orações. Neste período ele e seu pai também participam das peregrinações aos grandes santuários marianos da Polônia, como o de Czestochowa, onde se adora uma imagem negra da Virgem. Segundo Portier, a devoção mariana é, sem nenhuma dúvida, um traço do catolicismo polonês que é vivido intensamente por Karol, segundo alguns biógrafos, para suprir-lhe a falta de sua mãe - que faleceu quando ele tinha apenas nove anos. A intensidade de sua devoção o faz aderir à liga mariana de Wadowice e a orar diariamente por Nossa Senhora na capela próxima a sua casa.

Importa destacar que sua devoção a Nossa Senhora, e em especial a Virgem Negra de Czestochowa, permanece durante toda a sua vida e ajuda a explicar algumas de suas atitudes como Papa. Esse tema será aprofundado a seguir, neste ponto apenas destacamos, como exemplo, que no ano de 1999 João Paulo II consagra a Polônia à proteção de Nossa Senhora de Czestochowa, o Santuário Mariano para o qual peregrinava na infância e símbolo de sua antiga devoção a Nossa Senhora.

Além da forte adesão às práticas devocionais do catolicismo polonês, Karol também realiza neste período a leitura de São Luis de Monfort, importante teólogo mariano, embasando a sua devoção a Nossa Senhora em conhecimentos teológicos que irão acompanhá-lo durante a sua vida.

A devoção do Papa a Nossa Senhora, formada durante a sua infância no catolicismo polonês é retomada e explicitada em suas atitudes como sacerdote - bispo e Papa. Inclusive, durante o seu sacerdócio ele reforça a sua devoção à Maria, dedicando sua vida religiosa a ela. Em 1958, quando se torna bispo, proclama-se “Totus tuus” à Maria, ou seja, todo seu, dedicando seu episcopado para a Virgem. A mesma dedicatória é refeita vinte anos mais tarde, quando inicia o seu pontificado. A devoção de Karol Wotjila a Maria lhe é tão cara que está estampada em seu brasão de líder do Vaticano, no qual se observa um M, de Maria, bem como a inscrição “TOTUS TUUS”.

Outras atitudes de João Paulo II durante o seu papado foram demonstrativas de sua fé e devoção a Maria. A mais explícita delas ocorreu após a sua sobrevivência ao atentado a tiro sofrido em 1981, em que atribuiu a sua salvação a Nossa Senhora, especificamente a Nossa Senhora de Fátima, uma aparição. Devido a este atentado, ele se coloca “devedor da Santíssima Virgem. Poderia esquecer que o acontecimento na Praça de São Pedro ocorreu no dia e na hora em que, há mais de sessenta anos, se 
recorda em Fátima, em Portugal, a aparição da Mãe de Cristo para pobres pastores? Em tudo aquilo que aconteceu exatamente nesse dia, notei uma extraordinária proteção e solicitude maternal. Esta mostrou-se mais forte do que a bala assassina.” (184)

Assim, para o Papa, não foi uma coincidência a data do atentado - treze de maio - ser a mesma da aparição de Nossa Senhora na Vila de Fátima. Ele acreditou que devido à interferência da Virgem sobreviveu e saiu ileso da bala que o feriu gravemente. Em entrevista publicada ele afirma que "alguém tinha guiado e desviado aquela bala" (179), referindo-se ao fato de que o atirador, Ali Agca, era um assassino profissional e que sabia atirar muito bem, no entanto, Nossa Senhora de Fátima teria desviado a bala, impedindo a sua morte ${ }^{46}$.

João Paulo II, como devedor da Virgem de Fátima, realizou uma peregrinação para o Santuário português, para agradecer a Virgem pela graça recebida. Nesta ocasião, exatamente um ano após o atentado, em 13 de Maio de 1982, depositou a bala que o havia ferido na coroa da Virgem de Fátima, onde se encontra até hoje.

Essa atitude de Karol Wotjila, além de demonstrar a sua fé em Maria, repercutiu sobre a aparição portuguesa, promovendo-a. Ela passou a ocupar espaço na mídia internacionalmente, sua história foi recontada e relembrada. A devoção de João Paulo II e a sua peregrinação em agradecimento a Virgem colocaram esta aparição em destaque no catolicismo.

O brasão e a peregrinação para Fátima, como cumprimento de uma promessa, são exemplos de ações de João Paulo II que contribuíram para a valorização da devoção a Nossa Senhora mundialmente. Suas palavras, afirmando que foi a "mão maternal de Maria” que desviou a bala "assassina” foi amplamente divulgada, e, com ela, a crença do Sumo Pontífice nas intervenções de Nossa Senhora na vida dos homens.

Após esta primeira peregrinação o Papa esteve mais duas vezes em Fátima, em 1991 e 2000, sempre no aniversário das aparições, sendo que na sua última visita beatificou dois pastores videntes - Jacinta e Francisco. Em cada uma destas peregrinações mobilizou milhares de fiéis, promovendo a valorização do Santuário.

\footnotetext{
${ }^{46}$ Outra evidência da interferência de Nossa Senhora neste episódio, segundo o Papa, foi o interesse do atirador pela Virgem de Fátima, especificamente pelos segredos. Segundo ele, quando foi visitá-lo "ficou claro que Ali Agca continuava a interrogar-se como era possível ter falhado o atentado. (...) O dado mais interessante é que essa inquietude o tinha levado a se interessar pelo problema religioso. Perguntava o que era feito do segredo de Fátima, em que consistia o segredo" (184). Ou seja, o Papa considerava que o criminoso tinha percebido a interferência de Nossa Senhora no evento, mais forte do que a sua habilidade como assassino.
} 
A devoção de João Paulo II a Nossa Senhora e as suas peregrinações são duas fontes importantes de legitimidade para as aparições de Nossa Senhora, pois ele se mostra publicamente como devoto e como peregrino, dá o próprio exemplo de devoção para os católicos, destacada pela realização da peregrinação.

Nesse sentido, as peregrinações de João Paulo II não foram exceções em seu pontificado, pelo contrário, elas eram extremamente comuns. Durante os vinte e seis anos que Karol Wotjila esteve à frente do Vaticano ele visitou cento e vinte e nove países e mais de mil localidades, tornando-se conhecido como o "Papa peregrino”. Em cada uma de suas peregrinações atraia uma multidão de fiéis e suas ações ocupavam espaço na mídia. Ou seja, elas não passaram despercebidas, pelo contrário, eram alvo de grande divulgação.

Concomitante a valorização da peregrinação, há também uma política de incentivo aos Santuários - não apenas os Marianos, mas os Santuários do catolicismo em geral. A promulgação do código de direito canônico, que regulariza a situação dos Santuários de peregrinação e busca estimulá-los, ocorre durante o seu papado ${ }^{47}$.

João Paulo II desempenha um papel central neste processo, pois durante suas inúmeras viagens ele realizava peregrinações entre os Santuários católicos. Sempre em suas visitas aos países passava por algum Santuário importante da região, escolhendo estes locais para a realização de seus pronunciamentos oficiais. (Dayan, 1990). Mencionamos o exemplo de Portugal, em que nas três visitas realizadas ao país passou por Fátima. Quando esteve no Brasil visitou o Santuário de Aparecida, procedendo de maneira semelhante na maioria de suas visitas aos demais países. Inclusive, o título de "papa peregrino” advém não apenas de suas viagens, mas de sua passagem pelos Santuários nestas ocasiões, em peregrinação.

No que se refere especificamente às aparições, além de Fátima, João Paulo II peregrinou por todos os Santuários marianos oficialmente reconhecidos, levando milhares de fiéis a estes locais e os promovendo internacionalmente, devido a grande divulgação de suas viagens na mídia. Assim, o Papa promovia o Santuário, devido à multidão que o acompanhava e a divulgação na mídia, mas também, e principalmente, o valorizava, bem como ao ato de peregrinar, devido a seu próprio exemplo de fé.

\footnotetext{
${ }^{47}$ Renata Menezes, em seu texto sobre o Santuário de Santo Antônio do Largo da Carioca já havia destacado esse aspecto, demonstrando a revalorização realizada pela Igreja, por meio de seus monges, neste antigo Santuário do Rio de Janeiro.
} 
A atribuição de valor ao Santuário pela sua devoção foi percebido nos Santuários de Lourdes e Fátima, em que os postais que retratam o Papa diante das imagens da aparição são colocados em destaque nas bancas de venda de lembranças, abundantes nestes locais. Em Lourdes há dois postais, um sobre cada visita realizada por João Paulo II à cidade, ambos enfocando a devoção do Pontífice a Nossa Senhora de Lourdes, orando diante da grota em que Maria apareceu.

Pelos postais podemos perceber a importância da devoção do Papa para os peregrinos. Ela atribui ainda mais valor aos eventos, pois o mais importante representante de Deus, chefe da Igreja e único homem considerado infalível pelos católicos, explicita a sua devoção e fé nas aparições de Nossa Senhora. Os peregrinos fazem questão de comprovar esta devoção, levando para casa os postais que demonstram a devoção do Papa àquela aparição.

Dessa forma, a peregrinação de João Paulo II entre os Santuários importantes do catolicismo foi duplamente importante para seu Pontificado. Por um lado divulgava a sua imagem e a da Igreja Católica pelos locais por onde passava. Cada viagem sua mobilizava os países, não apenas os católicos, mas a mídia e o poder público, divulgando intensamente a passagem do Papa. Por outro lado, trazia ainda mais valor para o local, pois, mesmo que as peregrinações ocorressem apenas nos Santuários reconhecidos, o fato de um Papa peregrinar, ainda mais, mostrar-se como devoto, traz ainda mais valor ao Santuário. Os postais documentando a passagem e a devoção de João Paulo II, presentes nos Santuários de Lourdes e Fátima, são exemplos disso.

Assim, durante todo o seu papado João Paulo II deixou clara a sua devoção a Nossa Senhora, explicitada de diferentes formas, especialmente nas peregrinações. Além disso, também demonstrou sua crença e devoção às aparições marianas. Nesse sentido, a Virgem de Fátima lhe era especial. Em diferentes momentos o Papa proclamou-se devoto de Nossa Senhora de Fátima - importante referência para as aparições marianas no Brasil. O primeiro deles já foi mencionado neste capítulo, o atentado sofrido em 13 de Maio de 1981. Posteriormente, anos mais tarde, já no final da década de noventa, o Papa revela o terceiro segredo de Fátima ${ }^{48}$, segundo ele o próprio atentado. A divulgação do segredo colocou a aparição novamente em evidência, pois,

\footnotetext{
${ }^{48}$ As aparições de Nossa Senhora em Fátima tem como característica importante as mensagens e segredos transmitidos pela Virgem aos videntes. Seriam três segredos, sendo que os dois primeiros já haviam sido revelados ao longo do século XX. Já em torno do terceiro pairava um enorme mistério, cercado de suposições escatológicas por parte dos devotos, sendo que, no final da década de noventa João Paulo II o revela, rompendo com todas as expectativas sobre o fim do mundo a seu respeito e chegando a decepcionar alguns de seus seguidores.
} 
durante todo o século XX houve muitas especulações sobre ele, geralmente de cunho escatológico, e João Paulo II, ao divulgá-lo, acabou com o mistério e, além de promover mais uma vez a aparição, demonstrou a veracidade das profecias reveladas aos pastores. Ou seja, através desta revelação, em que demonstra a veracidade das revelações pela sua concretização, aferiu ainda mais legitimidade às aparições.

Outro momento importante foi a beatificação dos pastores videntes de Fátima - Jacinta e Francisco - por João Paulo II. Os dois videntes morreram ainda crianças, poucos anos após as visões, e o processo para sua beatificação, iniciado na década de trinta, foi reativado apenas durante o papado de Karol Wotjila. No final da década de noventa, durante a terceira visita do Papa a Fátima, ele realizou a beatificação dos videntes, demonstrando mais uma vez a sua fé nas aparições de Nossa Senhora.

As atitudes de João Paulo II demonstram não apenas a sua devoção a Nossa Senhora, mas sua crença nas aparições e mensagens de Maria - percebida nos postais, na beatificação dos videntes e principalmente na revelação da concretização do terceiro segredo de Fátima. Dessa maneira, ele contribuiu para a agregação de valor às aparições de Nossa Senhora por meio de seu exemplo de fé, explicitado em vários momentos de seu pontificado, especialmente em relação à aparição de Fátima.

Interessa notar que esta postura de Karol Wotjila agrega valor também a outras manifestações marianas, além de Fátima. Nas aparições de Nossa Senhora no Brasil, como em Jacareí, a importância da devoção de João Paulo II é notada. Embora ele não tenha conhecido esta manifestação, por ser devoto confesso de Maria e das aparições as referências a ele são comuns durante os cenáculos.

Há, por exemplo, mensagens de Maria especificamente sobre ele, como a seguinte: “deixem-se conduzir fielmente pelo magistério de meu querido João Paulo II, o Papa preparado e formado por mim para esses dias, e que é o meu filho mais querido”. (Nossa Senhora, no dia 07/11/1995). Assim, ele é considerado como um Papa especial, como o Papa dos últimos dias, sendo a sua proximidade com Maria sempre lembrada. Ele é percebido como “o Papa de Nossa Senhora”, demonstrando que a sua importância e suas ações se estendem para além dos Santuários para os quais peregrina, atingindo inclusive as aparições não reconhecidas, como a de Jacareí.

\section{2) A “nova” peregrinação}

A peregrinação pelos Santuários Católicos foi uma característica marcante do Pontificado de João Paulo II, bem como o aumento no número de canonizações e 
beatificações. Seu pontificado foi o que promoveu o maior número de canonizações nos últimos tempos - o número santificações e beatificações mais que triplicou durante esse período em relação aos Papas anteriores, foram cento e quarenta e sete beatificações e cinqüenta e uma canonizações. Dessa maneira, João Paulo II também incentivou a devoção aos santos, além de Nossa Senhora.

Sob esse aspecto, alguns autores o consideram como um Papa que soube se valer das devoções do catolicismo popular, incentivando as peregrinações, os Santuários, as devoções a aparições e a promoção de canonizações e beatificações. Especificamente no que refere a peregrinação, - central durante o papado de João Paulo II - notamos a utilização de um antigo ritual católico pelo Papa. Entretanto, ele atribui novas características e sentidos para essa antiga prática, pois não só peregrina pelos Santuários como um devoto, mas considera que a Igreja deve peregrinar por meio da fé.

Nesse sentido, a importância atribuída à peregrinação e os novos sentidos dados a ela são observados em suas posturas e políticas frente ao Vaticano. A encíclica “Redemptoris Mater”, escrita em 1987 por João Paulo II, é um exemplo disso. Nela o Papa estabelece "uma caminhada da Igreja, junto com Maria, rumo ao terceiro milênio”, determinando uma dinâmica/programa de Maria e da Igreja que são indissociáveis. Nela, apesar do Papa retomar vários aspectos importantes da Virgem, como a mediação e a maternidade, seu foco é o movimento, segundo ele “A Igreja está em marcha, como Maria ao partir para as montanhas de Judá após a anunciação”. (Lc 1,39). O Papa usa a palavra "peregrinação” mais de vinte vezes, bem como "rota”, “itinerário”, “caminho”, ele considera que a Igreja está em caminhada, e que Maria é o ponto de partida desta peregrinação, pois é uma marcha que acontece pela fé, que teve início com Nossa Senhora, no momento da anunciação.

Este ponto nos chamou a atenção, pois destaca a importância da peregrinação, porém não dos fiéis, mas da própria Igreja por meio de um movimento iniciado com Nossa Senhora. Esse é a idéia central da encíclica, oficializando a importância do peregrinar e considerando Nossa Senhora como a grande peregrina da fé. Trata-se, pois, de uma concepção de peregrinação semelhante à observada no primeiro capítulo, em que não são apenas os fiéis que peregrinam em busca do sagrado, mas é o próprio sagrado que se movimenta pelo mundo - marcha, caminha, peregrina, como os termos que indicam movimento na encíclica mencionada.

A benção que o Papa realizava pelos países que passava, beijando o chão, também pode ser compreendida neste contexto significativo. Ou seja, ele levava a sua 
benção até os territórios, não era preciso que os fiéis fossem em busca dela no Vaticano, ela ia até eles, em seu país, através do próprio Papa.

Ou seja, João Paulo II usa de uma antiga prática católica, a peregrinação, sem se desfazer de seus antigos sentidos - pois demonstra a sua devoção, peregrinando e orando nos Santuários - mas também lhe atribuindo novas características, especialmente relacionadas ao movimento da Igreja e da fé, que não podem ficar paradas, elas também têm que caminhar, então, quando ele peregrina leva consigo a fé e a Igreja. É uma peregrinação de duplo sentido, a do Papa devoto para os Santuários, mas também a do Papa representante da Igreja para as localidades, levando a fé, a sua benção, e uma multidão de fiéis.

Importa destacar a presença desta prática em uma encíclica, que justifica doutrinariamente as viagens do Papa e conclama toda a Igreja, todos os católicos a realizarem a caminhada da fé - que possui um sentido mais amplo que a peregrinação para um Santuário.

Dessa forma, o próprio Papa é o exemplo do agir religioso contemporâneo em que a peregrinação ganha centralidade. Como os peregrinos analisados no primeiro capítulo, João Paulo II peregrina pelos Santuários, e, como os eventos extraordinários, leva consigo o sagrado, e a própria Igreja.

Assim, notamos a permanência da importância de elementos da tradição no agir religioso contemporâneo, como no caso da peregrinação, em que a devoção aos santos e a visita aos Santuários são ainda importantes, mas a ela são agregadas características do mundo contemporâneo, como a circulação dos eventos e da Instituição - eles vão até os fiéis, não são apenas eles que vem até os fenômenos. Ou seja, é uma movimentação não apenas de pessoas, mas da Igreja, com suas crenças e devoções, instituída e realizada por seu representante máximo, e observada também nas práticas de seus seguidores. Voltamos, pois, para a concepção de “ajustamento” desenvolvida por Portier (2006), pois o Papa e os peregrinos se valem de uma prática tradicional do catolicismo, constituída de elementos tradicionais, mas que se ajusta à sociedade contemporânea, em que a circulação e a fluidez são marcantes, mas sem subverter seus antigos (mais ainda presentes) elementos. 


\section{5) A organização hierárquica e burocrática da RCC: Disseminação de}

Idéias e práticas

No primeiro capítulo demonstramos a importância do movimento carismático na organização dos rituais das aparições - os Cenáculos. Neste ponto devemos discutir a importância da RCC para a reprodução e disseminação das crenças e práticas relacionadas à devoção às aparições de Nossa Senhora. Para isso retomamos as características hierárquica e burocrática da RCC.

A RCC possui uma organização interna hierárquica, paralela e independente da hierarquia oficial da Igreja Católica. No topo dessa hierarquia está a Renovação Carismática internacional, seguida pela coordenação na América Latina e pela a coordenadoria nacional do movimento. Entretanto, a Renovação Carismática Nacional possui certa independência em relação aos níveis superiores, no que se refere às crenças e diretrizes a serem tomadas pelo movimento. (Carranza, 2000) Já nacionalmente as decisões da Coordenaria Nacional devem ser acatadas e seguidas em todo o país, também representado por coordenadorias, em nível estadual, diocesano e municipal. Ou seja, nacionalmente a RCC possui uma rígida estrutura hierárquica, em que o centro do poder de decisão sobre as crenças e os rumos a serem tomados pelo movimento está na coordenadoria nacional. Essas coordenadorias são formadas majoritariamente por leigos, embora em alguns casos exista a presença de clérigos e religiosas.

As coordenadorias são eleitas pelos votos dos participantes do movimento os servos, fiéis que participaram de pelo menos um Seminário de Vida no Espírito Santo. Entretanto, os servos apenas têm direito ao voto nas eleições das coordenadorias municipais, cujas lideranças têm direito a voto nas eleições das coordenadorias diocesanas e assim sucessivamente. A cada dois anos acontecem as eleições para as coordenadorias. Essa estrutura hierárquica, bem como o sistema eleitoral carismático, estão estabelecidos no estatuto da RCC.

Remetendo-nos a Weber, podemos perceber nessa organização aspectos burocráticos, da chamada dominação legal, cuja característica básica, segundo o autor é: "qualquer direito pode ser criado ou modificado mediante um estatuto sancionado corretamente segundo a forma. A associação dominante é eleita ou nomeada” (2000:128). A RCC possui não apenas um estatuto sancionado, como uma associação dominante eleita com base nas regras estatuídas. 
Segundo Carranza (2000), a partir de 1995 a coordenadoria nacional determinou a chamada “Ofensiva Nacional”, que, além de estabelecer as estratégias de expansão do movimento - objetivando expandir a RCC para todas as paróquias do país -, pretendeu estabelecer suas bases doutrinárias, sistematizando suas crenças e rituais. Para atingir sua meta procurou padronizar os rituais carismáticos e homogeneizar suas crenças, principalmente através da formação de lideranças.

A coordenadoria nacional tem constantemente reiterado a importância da padronização dos rituais carismáticos. Para isso procura que cada um deles siga uma forma pré-estabelecida, que contenha determinados elementos rituais e que esses elementos sigam uma ordem. Para tal divulgam CDs com conteúdos temáticos. Percebemos, pois, através desse incessante esforço de padronização dos rituais do movimento, a tentativa de estabelecer um sistema de crenças e ritos considerados oficiais pela coordenadoria nacional a serem seguidos pelas bases.

Um elemento importante desse esforço é a formação das lideranças. Para isso criaram-se escolas de formação nos dons do Espírito Santo, com o nome dos Apóstolos. Cabe aqui destacar duas delas, mencionadas por Carranza:

"Projeto Pedro: tem como objetivo a formação de pregadores - visa homogeneizar estilo e doutrina das pessoas que fazem pregações em nome da RCC.”

"Projeto Escola Paulo: tem como objetivo desenvolver materiais para formação de lideranças na RCC” (2000:60)

A “formação" passa a prevalecer como exigência da hierarquia para o reconhecimento das lideranças. Ou seja, o fiel deve comprovar sua competência para desempenhar a função de coordenador/pregador através de uma graduação formalizada pela cúpula, através da participação em cursos organizados pela coordenadoria nacional. Para cada tipo de liderança há uma preparação específica. Os pregadores, por exemplo, devem fazer os cursos ministrados pelo Projeto Pedro.

Forma-se, então, um corpo de especialistas da RCC, que é responsável pela disseminação do sistema de crenças do movimento. Enfatizamos que, através dessa organização burocrática altamente hierarquizada, a RCC cria uma rede de poder religioso quase totalmente controlada por leigos, o que, em se tratando de Igreja Católica, representa uma característica interessante.

Além disso, importa destacar que, apesar da RCC ser um movimento em que a experiência do contato com as figuras divinas é central, seus rituais também possuem uma exaustiva parte “didática”, composta por uma série de palestras sobre o sistema de 
crenças do movimento e sobre a doutrina católica, ministradas pelos pregadores e lideranças formados na RCC. Os retiros, por exemplo, possuem ao menos duas pregações diárias, que podem durar até duas horas. Ou seja, os participantes do movimento são constantemente informados sobre a fundamentação de suas crenças e práticas, de acordo com o que foi estabelecido pela hierarquia carismática - que forma os pregadores que realizam as palestras.

Dessa maneira, a RCC busca homogeneizar seu sistema de crenças e práticas, formando seus pregadores para realizar palestras em seus rituais de base. Como o "cérebro" do movimento é a RCC nos Estados Unidos, é de lá que parte a maioria das idéias e da fundamentação de crenças e práticas, que chegam até suas bases por meio dos cursos de formação de pregadores e, em seguida, das palestras realizadas por eles nos rituais carismáticos.

Carranza (2000) menciona a organização dos projetos de formação e a estratégia de disseminação do movimento - a Ofensiva Nacional - e de seu sistema de crenças, analisando o movimento carismático como uma inversão de papéis na estrutura do campo religioso constituído pela Igreja Católica, pois, são os leigos que manipulam o sagrado nesse movimento, manipulando seus principais bens de salvação, como observamos no capítulo anterior. Segundo Carranza, remetendo-se a Bourdieu:

"Sendo que os sacerdotes são os administradores do monopólio do sagrado, cabe aos leigos o papel de estranhos e ignorantes da religião, isto é o princípio da estruturação do campo religioso (a formação de duas classes: leigos e sacerdotes) e a oposição entre sagrado e profano” (2000: 139)

Realmente, é importante considerarmos que a RCC pertence ao campo religioso católico, devendo prestar contas a sua hierarquia e que, ao permitir o acesso ao sagrado aos leigos estabelece uma inversão de papéis nesse campo religioso, eliminando dessa relação o poder de intermediação dos sacerdotes.

Em nossa análise, entretanto, importa reter a análise da estruturação organizacional do movimento carismático. Consideramos que a cúpula da RCC, na verdade, pretende estruturar o movimento como um campo religioso autônomo, formando internamente duas classes - fiéis e lideranças - sendo que as lideranças deteriam o monopólio do sagrado. Os novos “sacerdotes”, nesse caso, seriam os fiéis que desenvolvem a competência para exercer a função de lideranças devido à formação 
nos cursos estabelecidos pelas coordenadorias. Ora, ao exigir a formação, o movimento restringe o acesso direto ao sagrado, ao carisma, constituindo a maioria dos fiéis como leigos, desprovidos de acesso aos bens de salvação.

Se, como bem observa Bourdieu, os aparelhos religiosos apresentam graus de desenvolvimento e diferenciação "das instâncias objetivamente incumbidas de assegurar a produção, a reprodução e a difusão dos bens religiosos, segundo sua distância em relação a dois pólos extremos, o auto consumo religioso, de um lado, e a monopolização completa da produção religiosa por especialistas, de outro lado" (1998:40), podemos pensar que, com relação à hierarquia católica, a RCC procura estabelecer-se como campo religioso autônomo, procurando monopolizar a produção e a reprodução religiosa por um corpo de especialistas, e, com relação a seu público interno, reproduz a diferenciação religiosos/leigos, procurando restringir o auto consumo religioso. Com efeito, ao impor esse grau de burocratização às lideranças a coordenadoria nacional restringe enormemente a manipulação dos bens de salvação e caminha para a distinção de duas classes: leigos e "sacerdotes”, no sentido adotado por Bourdieu, em que os sacerdotes são detentores do monopólio e gestão do sagrado e os leigos ignorantes da religião e estranhos ao sagrado.

Não apenas a constituição de um corpo de especialistas, mas o estabelecimento de instâncias organizadas com vistas à produção, reprodução e difusão dos bens religiosos caracteriza a constituição da RCC como um campo religioso autônomo. A necessidade da participação das lideranças nos projetos de formação estabelecidos pela hierarquia é o melhor exemplo disso, sendo a partir delas que a ocorre a reprodução e difusão das idéias e do sistema de crenças do movimento.

Especificamente no que se refere às aparições de Nossa Senhora, a estrutura hierárquica e burocrática da RCC é fundamental para a disseminação da crença e devoção a estes fenômenos. Exemplos disso são as justificativas teológicas realizadas pelo Pe Laurentin, que, como demonstramos anteriormente, estão presentes nos discursos dos carismáticos. Assim, a partir do contato do teólogo com o movimento nos Estados Unidos, onde está localizada a sua coordenação internacional - principal produtora de idéias e crenças para o movimento -, tem início a reprodução e a disseminação de suas justificativas teológicas para devoção à Maria e a suas aparições, que são observadas entre os carismáticos no Brasil.

Dessa maneira, se Laurentin contribui para a formação da legitimidade deste tipo de fenômeno, a partir da produção de idéias e crenças e da realização de palestras; a 
RCC internacional, por meio de sua organização hierárquica e burocrática, tem papel fundamental na disseminação dessas crenças, fazendo-as chegar aos membros da base do movimento, que podem desenvolver o interesse pelas aparições marianas e peregrinar para esses eventos. 


\section{TERCEIRO CAPÍTULO}

\section{AS APARIÇÕES DE NOSSA SENHORA EM JACAREÍ: CONTINUIDADE E MODELAGEM}

\section{1)Continuidade Simbólica e Modelagem nas Aparições Contemporâneas}

A existência de um modelo de aparições de Nossa Senhora formado no século XIX é afirmado por vários estudiosos do tema. Não há, porém, um consenso dos autores sobre essa questão. Nem todos concordam com a concepção de que as aparições marianas são fenômenos característicos do período mencionado. A principal delas é Syvie Barnay (2000), que em sua obra "Le ciel sur la terre: les apparitions de la vierge au moyen age” afirma que as aparições de Nossa Senhora estão presentes de forma significativa no catolicismo há muitos séculos. Segundo ela, os estudiosos não se interessaram em compreender o seu significado nos períodos anteriores, como durante a idade média, período ao qual ela se dedica. Assim, considera que a crença nas aparições, surgida no século IV, nunca deixou de existir, contabilizando mais de 5000 relatos entre o século IV e o século XX.

Barnay realiza uma caracterização das aparições em cada período, sendo aparições privadas para religiosas e religiosos. No ocidente as visões começam por volta do século $\mathrm{X}$, e ocorrem para os monges, principalmente através de sonhos. Nesse período são construídas várias catedrais dedicadas a Nossa Senhora, é o momento de grande difusão da devoção a Maria no ocidente. Importa destacar que a figura da mediadora entre Deus e os homens começa a se constituir neste momento. Ela é considerada responsável pelas relações entre os homens e a hierarquia celeste, por isso lhe pedem clemência, pois ela se encarregará de estabelecer o contato com o mundo divino. Segundo Barnay, são os monges de Cluny que começam a chamá-la de Mãe de Misericórdia, por ser a responsável pelos pedidos de clemência realizados pelos homens. 
Neste ponto importa destacar que a concepção de Maria como mediadora e como Mãe de Misericórdia é central nas aparições contemporâneas, sendo parte importante da simbologia mariana nestes eventos. Segundo a explicação dos participantes, Maria aparece por que é Mãe de todos os homens, e se preocupa com o destino de cada um de seus filhos - a chamada "Salvação", todos devem conseguir o Reino do Céu após a morte. É a figura da mãe de misericórdia que se destaca neste contexto. Analisaremos cuidadosamente os elementos simbólicos que constituem as aparições na atualidade no próximo capítulo. Queremos apenas destacar que a imagem de Maria como Mãe de Misericórdia é muito antiga, remontando ao século X e sendo contemporânea aos primeiros relatos de visões de Nossa Senhora para monges no ocidente. Dessa maneira, há elementos importantes presentes nas aparições, especialmente no que se refere à simbologia mariana, que possuem origem bastante anterior ao período de formação de um modelo para estes fenômenos: o século XIX. No próximo capítulo nos dedicaremos à análise das características associadas a Nossa Senhora nas aparições contemporâneas, demonstrando sua longa duração no imaginário católico e a sua permanência nas manifestações atuais, bem como os sentidos atribuídos a elas. Já neste capitulo buscamos compreender as características centrais das aparições marianas atuais - e não as da Virgem especificamente -, demonstrando, por um lado, que várias destas características ganham importância a partir do século XIX, mas, por outro lado, que vivenciamos, a partir da década de oitenta do século XX, o que chamamos de um "novo ciclo de aparições”, em que novos elementos se tornam centrais. Entretanto, importa destacar que a aproximação com o modelo de aparições estabelecido no século XIX constitui importante fonte de legitimidade para esses fenômenos.

Dessa forma, apesar da permanência dos traços de longa duração, várias das características presentes nas aparições marianas atuais têm origem nas aparições modernas, como demonstraremos a seguir. Porém, há também elementos centrais destes eventos que já estavam constituídos e presentes no imaginário católico no século XIX. Ou seja, apesar deste ser o momento considerado inaugural deste tipo de manifestação por alguns autores, importantes elementos simbólicos que as constituem não são novidades estabelecidas por elas. Pelo contrário, estudos sobre as aparições marianas deste período demonstram que elas apenas obtêm legitimidade devido ao reconhecimento dos elementos simbólicos por parte da população local. 
Vale a pena nos aprofundarmos neste tema. Para isso nos reportamos ao estudo realizado por Ruth Harris (2001) sobre a aparição de Nossa Senhora de Lourdes. Em sua análise a autora expõe as condições políticas, sociais e religiosas que possibilitaram que as declarações realizadas pela vidente Bernadette fossem aceitas pela população local. Harris demonstra que “aquilo" que a pastora afirma ter visto se inscreve perfeitamente na "velha tradição dos Pirineus, repleta de histórias maravilhosas”. Há lendas, almas, feitiços, aparições em grotas, todo um imaginário do entorno das aparições que permite a sua aceitação pelos moradores locais ${ }^{49}$. Nesse sentido, a autora demonstra a sacralização da paisagem existente nos Pirineus, combinando velhas crenças e as práticas cristãs - como histórias de pastores que encontram imagens de Nossa Senhora que lhes pede a construção de capelas, entre outras. Além disso, destaca que Bernadette e os moradores locais tinham conhecimento destas histórias, citando dois relatos de aparições de Maria para pastores ocorridos próximos a Lourdes, sendo que um deles estava retratado na capela da vila ${ }^{50}$. Ou seja, os habitantes sabiam da possibilidade deste tipo de fenômeno, fato que serviu para legitimar a visão da pastora.

Ainda no que se refere à importância do imaginário local, Bernadette vê Maria como uma jovem de cerca de quatorze anos, muito pequena e branca. Essa descrição a associa as fadas e aos seres fantásticos da floresta, não correspondendo a imagem corrente da Virgem nos Pirineus - a juventude de Maria pode lembrar o momento da anunciação, mas esta representação não estava presente no contexto católico de Lourdes, e sim em suas lendas ${ }^{51}$.

A visão de Bernadette na grota de Lourdes estava, pois, repleta de elementos simbólicos presentes no imaginário local, que possibilitaram o seu reconhecimento pelos habitantes e facilitando a sua aceitação. Esta continuidade simbólica foi central para que o relato da pastora fosse considerado verídico.

\footnotetext{
${ }^{49}$ Nesta obra Harris demonstra também outras características importantes para a formação da crença e devoção à Virgem de Lourdes, entre elas a postura da vidente Bernadette e o embate político entre cientificismo/positivismo e a Igreja Católica neste período.

${ }^{50}$ A autora menciona a historia de Anglese de Sagazari, muito conhecida dos contemporâneos de Bernadette, e que possui caracteristicas muito semelhantes a da vidente - pobre, sem instrução, que passa por situações de falta de alimentos e recebe a aparição de Maria. Inclusive, a autora mostra as representações de ambas, cuja semelhança é impressionante, sendo que a representação de Bernadette reproduz a de Anglese.

${ }^{51}$ A autora menciona que Bernadette nunca se conformou com a imagem de Nossa Senhora de Lourdes elaborada a partir da sua descrição, considerando-a "muito grande e velha", e não jovem, branca e pequena como a "fadinha" que lhe apareceu.
} 
O trabalho de Elisabeth Claverie (2003) sobre as aparições de Medjugorje, na antiga Iugoslávia, também deixa clara a importância do reconhecimento simbólico local nas manifestações de Nossa Senhora. Na segunda parte de seu livro "Les guerres de la Vierge” a autora analisa a importância da dimensão local na composição da aparição, demonstrando como elas possuem sentido para os habitantes da região. Para isso busca compreender o lugar ocupado pelas aparições no sistema simbólico dos moradores e os caminhos traçados para a sua legitimação.

Claverie enfatiza que os questionamentos e disputas em torno da autenticidade do evento estiveram presentes desde o seu primeiro momento, sendo que a apropriação local deste fenômeno foi marcada aparições foram sistematicamente colocadas à prova, primeiro pelos pais e amigos/parentes dos videntes - os moradores locais -, em seguida pelos franciscanos e sacerdotes e enfim pelos representantes políticos do país.

Diante destes constantes questionamentos, como a aparição conseguiu se afirmar? Essa é a questão central do livro de Claverie, que se torna mais clara na segunda parte da obra. A autora demonstra que se há a dúvida é justamente porque a possibilidade da sua veracidade está presente no imaginário dos protagonistas da manifestação. "Isso já aconteceu, Ela já apareceu, Ela já veio se comunicar com crianças”, o uso destas expressões demonstra, segundo a autora, que para os envolvidos Nossa Senhora, mãe de Deus, pode aparecer para os homens, pois isso já ocorreu em outros lugares. Ou seja, a aparição não é algo completamente novo no contexto significativo dos Bálcãs, pelo contrário, o contato dos humanos com seres “sobrenaturais” faz parte do imaginário dos habitantes da localidade.

Entretanto, a construção da aparição não se encontra apenas neste imaginário, ela se produz nos próprios questionamentos. É a partir da dúvida e da sua superação que a aparição se afirma desde os seus primeiros dias. Exemplo disso é o modo como a afirmação da visão da Virgem, proferida por uma das videntes, é questionada pelos moradores locais e colocada à prova por eles. Assim, havia a possibilidade da aparição segundo os moradores, porém, nada garantia que se tratasse de Nossa Senhora ou de outro "ser extraordinário" - como fantasmas ou outras criaturas

\footnotetext{
52 Segundo Claverie, a dúvida perpassa todos os momentos da aparição desde o seu início. A princípio é colocada em dúvida pelos moradores locais, que duvidam da afirmação dos videntes, mas até os dias de hoje vários dos peregrinos vão até Medjugorje para constatar a veracidade do evento, sendo que em todos os momentos da peregrinação a autora pontua o constante movimento de se duvidar - dos videntes, dos franciscanos, dos peregrinos. Ou seja, a manifestação foi e ainda é diariamente colocada em prova.
} 
capazes de estabelecer uma ponte entre a dimensão humana e a dimensão sobrenatural, que povoam o imaginário local. Dessa maneira, foram as “avós” - mulheres idosas e consideradas detentoras de conhecimento sobre estes seres - que sugeriram que os videntes jogassem sal sobre a figura que lhes aparecia para saber se era a Virgem ou um fantasma ou mesmo o demônio. Ou seja, a existência de um ser sobrenatural que está em contato com os videntes é confirmada pela intervenção de protagonistas locais, que, apesar de a princípio duvidarem, acabam por reforçar a possibilidade de veracidade da aparição.

Assim, na medida em que as aparições vão ganhando dimensões maiores o seu questionamento também se estende. Como no caso dos franciscanos, cuja presença na região era importante. No repertório simbólico destes sacerdotes as aparições da Virgem para os humanos são possíveis, isso já aconteceu em outras localidades e outras épocas, eles têm conhecimento das aparições de Lourdes e Fátima, por exemplo. Ou seja, não se trata de algo extraordinário, completamente sem referências para eles, ainda assim, a dúvida sobre a veracidade destes eventos é muito forte. Por isso um dos padres franciscanos se põe a questionar diariamente os videntes, em busca de semelhanças com as aparições conhecidas e aceitas. Ele sabe que as aparições de Nossa Senhora para os humanos são possíveis, mas duvida que isto esteja ocorrendo ali em sua paróquia, por esse motivo coloca os videntes diariamente à prova.

O estudo de Claverie enfatiza dimensões importantes da aparição: por um lado, a importância do reconhecimento simbólico - as aparições não representam uma novidade no sistema simbólico dos locais, moradores ou sacerdotes - e por outro lado, a centralidade das relações que se estabelecem localmente, contribuindo para a atribuição de autenticidade ao fenômeno. Podemos dizer que a aparição vai sendo construída localmente, a partir das relações estabelecidas e dos elementos simbólicos acionados.

Nos termos de Claverie, a aparição passa a ser modelada. Para os franciscanos as aparições deveriam, ao menos, estar de acordo com determinados padrões recorrentes neste tipo de evento. Inicia-se, então, um trabalho de "modelagem” da Virgem de Medjugorje, de forma a torná-la mais aceitável por meio da sua aproximação com as manifestações conhecidas e, de preferência, reconhecidas. Assim, além do reconhecimento deste evento pelo imaginário local, há também um processo simbólico de adequação da aparição a um padrão de aparições estabelecido, trazendo ainda mais elementos de continuidade para estes fenômenos. 
Nesse sentido, notamos a importância de duas características das aparições marianas: a preexistência de um imaginário que permite o reconhecimento e a aceitação das manifestações, e a formação de um padrão para as aparições de Nossa Senhora a partir da segunda metade do século XIX, ao qual a aparição deve se assemelhar. Por hora nos deteremos no padrão estabelecido para as aparições marianas e na modelagem das manifestações contemporâneas, além de destacar as novidades presentes nestes fenômenos na atualidade.

Dessa forma, a concepção de que as aparições do século XIX inauguram um novo tipo de evento, com características específicas, merece ser nuançada. Há um fenômeno específico sendo constituído neste momento, do qual a aparição de Lourdes é o exemplo mais significativo - ao lado das outras duas aparições marianas francesas do século XIX, La Salette e Pontmain - porém, alguns elementos destas manifestações já estavam presentes anteriormente, como colocado por Barnay. A existência dos elementos de continuidade e o seu reconhecimento pela população são centrais para a aceitação das aparições do século XIX, como bem demonstrado por Harris em seu estudo sobre a aparição de Lourdes, e também das manifestações posteriores, como o caso de Medjugorje estudado por Claverie.

Os estudos que consideram o século XIX como o momento de inauguração das aparições marianas não mencionam essa continuidade simbólica. Tomamos como exemplo o questionamento de Albert Lorca (2002) sobre o trabalho de Sylvie Barnay (2000). Para Albert Lorca há uma distinção entre visão e aparição que não é abordada por Barnay. Segundo ela, as visões possuem o caráter privado, ocorrendo para uma única pessoa, geralmente um monge ou religiosa, que retira apenas benefício pessoal deste fenômeno. Já as aparições têm um caráter público, ou seja, apesar de ocorrerem apenas para poucos videntes, elas devem ser divulgadas para toda a humanidade, elas atraem fiéis, podem ser formados Santuários nos locais em que elas aconteceram. Por isso Albert-Lorca afirma que apenas a partir do século XIX as aparições ganham centralidade no catolicismo, pois considera que as manifestações anteriores, como as relatadas por Barnay, são apenas visões.

Já Barnay (2000) concebe como aparição a crença no contato entre a Virgem Maria e os homens, não importando seu caráter público ou privado. Por isso afirma a presença das aparições marianas no cristianismo no ocidente desde o século $\mathrm{X}$, contestando os autores que defendem a proliferação destes fenômenos na era moderna. 
Nosso objetivo neste item não é tomar partido neste debate, mas sim reter destes relatos históricos as características das aparições ao longo dos tempos. Nesse sentido, não há como negar a continuidade simbólica entre as aparições medievais, as aparições do século XIX e as aparições contemporâneas. Assim, a idéia de uma ruptura ou de uma divisão, como a proposta por Albert-Lorca entre visões privadas e aparições públicas não é a mais adequada para análise destes fenômenos na atualidade. Há elementos simbólicos de continuidade entre as visões para religiosos, as aparições modernas e as aparições contemporâneas.

Concordamos, pois, em parte com a tese de Barnay, segundo a qual a crença no contato entre Nossa Senhora e os homens é também significativa no período anterior a Idade Moderna - porém sem ignorar, como faz a autora, que estas manifestações possuem novas características a partir do século $\mathrm{XIX}^{53}$.

Passemos, então, a análise da modelagem das aparições contemporâneas segundo o padrão constituído no século XIX, embora lembrando que não são todas as características destes fenômenos que tem origem neste período. Ressaltamos apenas duas características centrais das aparições contemporâneas que já estavam presentes na Idade Media: as peregrinações e os Santuários.

\section{1) Santuários e Peregrinações na Idade Média}

Segundo Barnay um momento importante para as aparições é o século XII, quando a crença nas aparições adquire sucesso sem precedentes, estando associada às relíquias. Devido a elas são constituídos grandes Santuários, nos quais os relatos de contato entre a Virgem e os homens são comuns. Entretanto, apesar dos numerosos relatos de visões, os elementos centrais dos Santuários neste período são as relíquias, sendo que as pessoas podiam ter visões por passarem a noite ao lado delas. Ou seja, as aparições possuem papel de coadjuvantes nestes Santuários.

Além das visões, há peregrinações direcionadas para os Santuários, sendo que multidões de peregrinos partem para os Santuários em busca de curas, acreditando que Maria seria capaz de realizar milagres tão prodigiosos quanto os realizados por

\footnotetext{
${ }^{53}$ Além disso, os estudos mencionados não abordam a intervenção fundamental da Igreja Católica, por meio de seus sacerdotes, nas aparições do século XIX, central para a formação deste novo modelo - como demonstrado no capítulo anterior. Assim, consideramos que a principal diferença entre as aparições do século XIX e as anteriores é a forte influência exercida pela Instituição Católica em prol destes fenômenos. Este é o cerne do debate entre Albert-Lorca e Sylvie Barnay, embora não seja explicitado por elas.
} 
Jesus nos Evangelhos. Esses peregrinos eram provenientes de locais assolados por grandes crises, como epidemias e guerras. Assim, a figura do peregrino, central para nosso trabalho, já está presente neste momento. Ele é aquele que se desloca para um Santuário em busca de curas e milagres, especialmente nos momentos de crise.

O peregrino é uma figura central nas aparições marianas contemporâneas. Entretanto, a peregrinação e os Santuários passam por transformações ao longo do tempo, possuindo características específicas na contemporaneidade, como demonstramos no primeiro capítulo. Neste momento interessa reter que ambos surgem como elementos importantes para a cristandade ainda durante a Idade Média, e, embora o contato entre a Virgem e os homens tenha um lugar secundário nos Santuários, a concepção de um espaço físico privilegiado para o contato com o divino já está presente neste período.

Nesse sentido, aspectos importantes para as aparições marianas contemporâneas - como os Santuários como locais privilegiados para o contato com o divino, para os quais existe um deslocamento de peregrinos, começam a ser delineados neste período. A partir destes elementos retirados da literatura bibliográfica voltemos nosso olhar para os processos de modelagem que tiveram lugar no estudo de caso que realizamos nas aparições de Jacareí.

\section{2) O caso de Jacareí}

Para compreendermos a modelagem realizada nas aparições de Jacareí é preciso explicitar os grupos e atores envolvidos neste fenômeno e as relações estabelecidas entre eles - pois a modelagem deste evento é realizada pelos grupos que se apropriam do fenômeno em diferentes momentos - lembramos que as manifestações se iniciaram em 1991, desenvolvendo sua configuração ao longo de quase dezoito anos.

Assim, procuraremos aqui demonstrar as relações estabelecidas entre o vidente de Jacareí - Marcos Tadeu - e os diversos atores e/ou grupos envolvidos neste fenômeno, explicitando os fatores que colaboraram para a constituição da legitimidade das aparições, especialmente no final dos anos noventa e início dos anos dois mil, e, por outro lado, os fatores que levaram ao esvaziamento dos Cenáculos, a partir de meados da primeira década deste século.

Constatamos que o sucesso e a legitimidade das aparições estão relacionados a dois fatores: as semelhanças existentes entre elas e as aparições reconhecidas de Nossa Senhora - segundo o padrão estabelecido a partir do século XIX - e a sua inserção na 
rede de aparições marianas contemporâneas através da qual se estabelece a circulação de pessoas e fenômenos e o contato entre os elos, já descritos no capítulo anterior.

O número de elementos e características que compõem uma aparição é bastante amplo, por isso optamos por separá-los em três partes: as características do vidente, do local em que ocorrem os fenômenos e as mensagens transmitidas, destacando as continuidades e as inovações em relação às aparições reconhecidas, especialmente as ocorridas na segunda metade do século XIX e no início do século XX, classificadas por autores como Steil (2003) de "aparições modernas”. Três aparições modernas serão usadas para estabelecer as aproximações com as aparições da atualidade: La Salette, Lourdes e Fátima. Optamos por estas três aparições não apenas pelo período histórico, mas principalmente por serem aparições constantemente mencionadas pelos participantes das manifestações marianas no Brasil - peregrinos e videntes -, e por serem oficialmente reconhecidas e incluídas no “modelo” de aparições estabelecido no século XIX, segundo historiadores do catolicismo.

\section{1) O vidente e a $R C C$}

As aparições para o jovem Marcos Tadeu tiveram início em 1991, quando ele era ainda um adolescente de quatorze anos. Logo após as primeiras manifestações, quando o jovem havia contado o fato para sua mãe e para alguns vizinhos, a notícia sobre ela se espalhou rapidamente, por meio do boca-a-boca das primeiras pessoas informadas - sua mãe, alguns amigos e vizinhos.

Durante o ano de 1994 as manifestações continuaram de forma esporádica, sem uma periodicidade, apenas para o vidente, sem público. Neste período foi formado um pequeno grupo de oração, que se reunia diariamente para rezar o terço na casa do vidente. Estes primeiros participantes eram pessoas da localidade, que começaram comentar que aparições de Nossa Senhora estavam acontecendo em seu bairro.

A notícia se espalhou rapidamente, chegando até o pároco de Jacareí e aos integrantes da Renovação Carismática local, que se aproximaram do vidente, apropriando-se da manifestação. Já a postura do pároco foi mais cuidadosa, baseando-se na cautela aconselhada pelo Vaticano, tentando compreender o que se passava com o possível menino vidente.

Logo nos primeiros meses um grupo de carismáticos começou a participar do grupo de orações na casa de Marcos, acreditando na veracidade das aparições de 
Nossa Senhora e encarregando-se de "espalhar" a notícia sobre elas, fato que se deu rapidamente, por meio do acionamento da rede de contatos descrita no primeiro capítulo. Importa destacar que esse grupo não foi apenas responsável pela divulgação dos eventos, mas se apropriou do fenômeno em seus primeiros anos, modelando-o de acordo com o padrão de aparições reconhecidas. A partir do segundo ano das manifestações, elas passaram a ocorrer periodicamente, no sétimo dia de cada mês, data em que ocorreu a primeira visão para Marcos. Os carismáticos organizaram um ritual específico para este dia, que passou a ser chamado de Cenáculo, e contataram cada vez mais gente para a participação das aparições mensais. Devido aos contatos e a organização dos carismáticos, participantes vindos de cidades da região, depois do Estado e de todo o país começaram a participar dos rituais do dia sete, às seis horas da tarde.

Rapidamente este ritual não pôde mais ser realizado na casa de Marcos, devido à falta de espaço. Foi então que os carismáticos se encarregaram de mudar o Cenáculo para o “Monte escolhido por Nossa Senhora”. Já estamos no ano de 1998, e os rituais ainda acontecem no dia sete, no Monte, e recebe peregrinos do país inteiro, e até de outros países. Este é o período áureo das aparições, em que os Cenáculos chegam a contar com cinco mil participantes.

Nesta época, o vidente já possuía várias informações sobre outras aparições de Nossa Senhora, já tinha estado em contato com outros videntes de Maria no Brasil e realizado o circuito de aparições marianas internacionais. Tudo isso devido, em grande parte, ao apoio dos membros da RCC. O contato com outros videntes, por exemplo, ocorreu por meio da intermediação de integrantes da Comunidade Carismática Magnificat, de São José dos Campos, mencionada no primeiro capítulo.

A vidente com quem Marcos possuía contato mais estreito, no final da década de noventa, era Mirna, de Muriaé. Ela era uma das videntes “preferidas” do grupo de carismáticos de São José dos Campos, liderado por Olga, que realizava excursões freqüentes para Muriaé, e organizava a vinda da vidente para São José dos Campos. Por esse motivo Marcos a conheceu, participando das aparições na cidade mineira e das visitas de Mirna a São José dos Campos. Ou seja, pelo contato entre os carismáticos de Jacareí - que apoiavam Marcos - e os carismáticos de São José liderados por Olga, e que apoiavam Mirna - os videntes se conheceram e passaram a freqüentar cada um os Cenáculos do outro, realizando mesmo visões “coletivas” em que Nossa Senhora se manifestava e transmitia mensagens simultaneamente para ambos. 
Além disso, a participação de Marcos no encontro entre videntes marianos brasileiros, realizado pelo Pe Gobbi em 1999, também ocorreu devido à intermediação dos carismáticos. A Comunidade Carismática Magnificat foi informada de que o sacerdote italiano viria ao Brasil, e que realizaria um encontro entre os videntes de Nossa Senhora. Os carismáticos de Jacareí tomaram, então, a iniciativa de contatar Pe Gobbi e de indicar a presença de Marcos, que foi aceita pelo sacerdote.

A viagem de Marcos pelos Santuários marianos europeus, realizada no ano de 1998, foi também patrocinada pelos carismáticos de Jacareí, que organizaram uma “ação” para que os freqüentadores das aparições, bem como carismáticos de outras localidades, doassem alguma quantia em dinheiro para que Marcos pudesse viajar.

Dessa maneira, a apropriação da aparição pelos carismáticos, durante a década de noventa, foi fundamental para a constituição dos rituais e para a legitimação das manifestações. Através deles as aparições foram divulgadas e se tornaram legítimas, por meio da aproximação com as manifestações marianas reconhecidas. Os carismáticos também foram muito importantes para a “formação” do vidente, inserindo-o no universo das aparições marianas, informando-o sobre as características de outras manifestações, fornecendo-lhe detalhes sobre elas.

\section{3) As aparições de Jacareí: a modelagem e a produção da legitimidade}

No caso das aparições de Nossa Senhora em Jacareí a continuidade simbólica é central na atribuição de legitimidade ao fenômeno. Nelas a legitimidade é obtida a partir do reconhecimento das semelhanças com as aparições reconhecidas, que é percebido como o padrão instituído no final do século XIX. Ou seja, as novas aparições, como Jacareí, para se legitimarem devem passar pelo processo de modelagem sugerido por Claverie (2003) e adotar a forma de aparições reconhecidas.

Nesse sentido, notamos que a semelhança com as aparições reconhecidas é constante, sendo percebida positivamente pelos participantes, que a utilizam como exemplo da veracidade dos fenômenos, e não como plágio, imitação. Ou seja, o fato da aparição de Jacareí ser muito semelhante às manifestações anteriores e reconhecidas serve como "prova” de sua veracidade para os devotos.

A continuidade simbólica é observada em três aspectos principais, que serão analisados neste capítulo: a personalidade do vidente, as características do local da aparição- o Santuário -, e o conteúdo das manifestações - as mensagens proferidas. 
Importa destacar que várias destas semelhanças não estavam presentes nos primeiros relatos sobre as aparições, tendo sido acrescentadas ao longo do tempo, já nos primeiros anos dos eventos.

Por isso consideramos que a legitimidade deste fenômeno é advinda, em parte, da sua modelagem ao padrão de aparições reconhecidas. Nesse ponto notamos novamente a importância da RCC, pois, nos primeiros anos das aparições, quando Marcos ainda era um garoto, os membros do movimento, que possuíam contato e conhecimento sobre aparições marianas, passaram a moldar a aparição, acrescentandolhe elementos simbólicos e características semelhantes aos presentes nos fenômenos reconhecidos - a construção do Santuário, o relato das aparições e as características do vidente foram se aproximando do padrão legítimo.

Assim, na primeira década da aparição os carismáticos, como detentores do conhecimento sobre as aparições marianas legítimas e do contato com outras manifestações semelhantes, possuindo capital simbólico acumulado - obtido pela informação e circulação pelos Santuários reconhecidos - moldam o evento de Jacareí.

Estas características das aparições marianas nos remetem ao estudo de Pierre Bourdieu (1975) sobre o costureiro e sua griffe, em que ele aborda a produção da legitimidade de um produto - no caso estudado os produtos de griffe - como um processo de “alquimia social”, em que ocorre a trans-substancialização de um produto qualquer em um produto de griffe, por meio da assinatura do costureiro - mesmo que ele não tenha sido o produtor direto do produto, como no caso dos perfumes - sendo o valor simbólico atribuído a este produto - por possuir o nome da maison - que lhe concede legitimidade.

Importa-nos reter que a alquimia social somente obtém sucesso quando o criador possui capital simbólico - para que possa transferi-lo ao produto através de sua assinatura - e que a aquisição deste capital de autoridade somente acontece por meio da relação do criador com as maisons antigas e legítimas. Segundo Bourdieu, as rupturas de sucesso são aquelas em que os “novos” criadores são advindos das maisons antigas, sendo que o seu capital de autoridade foi obtido pela passagem por elas. Para Bourdieu, os pretendentes acumulam capital de autoridade levando a sério os valores e virtudes da representação oficial, eles podem acumular capital simbólico pelo contato e conhecimento com os elementos importantes em um determinado campo. Esses valores devem ser obedecidos - os pretendentes devem estar de acordo com as necessidades 
estabelecidas pelo campo - para a obtenção de sucesso. Assim, a busca da legitimidade dos pretendentes passa pela submissão às necessidades próprias de cada campo.

A análise dos processos simbólicos de produção de legitimidade nos ajuda a compreender melhor a centralidade da modelagem na produção da crença na veracidade da aparição. Para que uma nova aparição adquira legitimidade é preciso que ela se submeta as regras presentes nessa rede, sendo que isso ocorre por meio de seus agentes - participantes e videntes. Em Jacareí a adoção de uma série de símbolos e valores que são característicos desse tipo de fenômeno, ou seja, que pertencem às aparições marianas, é central para a constituição da legitimidade da aparição.

Novamente ressaltamos o papel central dos membros da RCC neste processo, pois nos primeiros anos da aparição eles são os detentores do capital de autoridade necessário para inserir esta manifestação na rede das aparições marianas, pois tem conhecimento sobre esses fenômenos - suas características e seu conteúdo - e circulam por outras manifestações do mesmo tipo - como demonstrado no primeiro capítulo.

Esse processo é simbólico e social. A modelagem é parte importante da produção da autenticidade da crença nas aparições. Os peregrinos, ao reconhecerem os elementos e símbolos das aparições legítimas, tendem a crer nos “novos” fenômenos como Medjugorje e Jacareí. Para uma aparição ser percebida como verídica é fundamental que ela acione elementos simbólicos dos eventos reconhecidos.

Neste processo de construção simbólica o vidente assume papel central, pois ele constitui parte do padrão. Para que a autenticidade da crença nas aparições seja constituída o vidente deve possuir traços de personalidade que, na percepção dos peregrinos, evidenciem o seu dom. Para eles, Maria não se comunicaria com "qualquer um”, mas apenas com uma pessoa “especial”. A raridade do vidente deve, pois, ser “provada” pelos seus traços de personalidade, que o tornam semelhante aos videntes marianos reconhecidos, sendo ele também modelado.

Lembramos que a fonte da sacralidade das manifestações encontra-se na convicção do outro, no caso, dos peregrinos. A modelagem do fenômeno e do vidente contribui para a formação desta convicção. A sua realização permite que os peregrinos percebam o fenômeno como autêntico, devido ao reconhecimento dos elementos simbólicos e dos traços de personalidade acionados. Passamos agora a análise do processo de modelagem. 


\section{1) A história}

\section{A) Quem é esta Jovem?}

Segundo o relato, a primeira aparição acontece em sete de fevereiro de 1991, quando o jovem Marcos Tadeu, na época um menino de 13 anos, está voltando para a casa e se sente “chamado” a entrar em uma Igreja e a orar. Enquanto realiza as orações aparece-lhe uma figura, uma jovem de cerca de dezoito anos, de uma beleza indescritível e toda iluminada. A jovem não se identifica, apenas o convida a oração.

As manifestações, ainda esparsas, prosseguem durante dois anos, nos quais a "Senhora” apenas dizia que vinha do Céu, que estava a serviço de Deus, sendo somente em 19 de fevereiro de 1993, devido a grande insistência de Marcos, que pergunta quatro vezes “quem é a Senhora”, que a jovem lhe responde: “Eu sou a mãe de Jesus”.

Duas características das aparições já podem ser observadas nesta história: a demora na identificação da figura e a maternidade de Maria - em sua frase de identificação ela se coloca como Mãe, no caso mãe de Jesus ${ }^{54}$. Analisaremos a importância da maternidade de Nossa Senhora a seguir, antes devemos aprofundar a não identificação da aparição.

A demora em se identificar aproxima as aparições de Jacareí das aparições modernas, em que a aparição não se identifica de imediato. Citamos aqui os exemplos de Lourdes e de Fátima, em que a figura que transmite as mensagens apenas se identifica no último dos encontros com os videntes. Em Lourdes, é somente na última das dezoito manifestações que a jovem diz ser a Imaculada Conceição. Em Fátima é também no último dos sete encontros com os pastores que a Senhora se identifica como Nossa Senhora do Rosário.

Inclusive a forma como ocorre a identificação é semelhante, a aparição não diz apenas ser Maria, mas acrescenta uma denominação específica, utilizando os seguintes termos:

\footnotetext{
"Eu sou a Imaculada Conceição" - Lourdes

“Eu sou Nossa Senhora do Rosário” - Fátima

“Sou a SENHORA DA PAZ! Sou a MÃE DE JESUS! - Jacareí
}

\footnotetext{
${ }^{54}$ A referência à maternidade, inclusive, já estava presente nos relatos de Marcos sobre as conversas com a "Senhora", em que ela o chamava de "meu filho", também se referindo ao restante da humanidade como "meus filhos".
} 
Assim, no que se refere ao relato da aparição de Jacareí, o suspense em relação à identidade da “figura luminosa” é semelhante ao ocorrido nas aparições modernas. Mesmo existindo várias evidências que permitem a classificação da aparição como Nossa Senhora, o relato é construído de forma a deixar clara a demora proposital da Virgem em revelar sua identidade.

Já na segunda aparição, em 19 de fevereiro de 1991, a Jovem - segundo eles

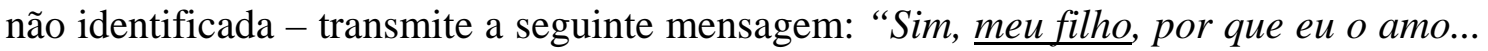
Mas não quero que venha sozinho, traga aqui também muitos dos meus filhos que Eu amo..." Ora, todos os católicos sabem quem é a “ figura iluminada” que pode se referir a eles como "meus filhos"! A concepção de Maria como "Mãe da humanidade” é recorrente e comum no catolicismo, não sendo preciso ser devoto das aparições para chamá-la de “Mãe”. Assim, todos já sabiam que a Jovem era, na verdade, Nossa Senhora, entretanto, isso somente é explicitado cerca de dois anos depois.

Corria na região o comentário de que Maria “estava aparecendo para um menino em Jacareí”, ele circulava entre os católicos, especialmente os ligados ao movimento carismático. A mídia local - pelos jornais Diário de Jacareí e Vale Paraibano - já tinha dedicado reportagens sobre o fenômeno, referindo-se a ele como “aparições de Nossa Senhora”. Ou seja, o público já considerava a figura como Maria, embora isso não tivesse sido dito pelo vidente.

Esta é, pois, uma primeira característica que demonstra a reiteração do padrão de aparições reconhecidas. Mesmo as mensagens deixando claro que se tratava de Nossa Senhora - além de referir-se aos homens como “meus filhos” o vidente a chama de "Jovem Senhora”, pois a figura que ele descreve aparenta ter dezoito anos - o “mistério” em torno da sua identidade permanece.

\section{2) O Santuário}

A) As aparições em local ermo

A primeira aparição de Nossa Senhora para Marcos Tadeu ocorreu na Igreja da Imaculada Conceição, na zona urbana da cidade de Jacareí. Durante os dois anos seguintes as aparições ocorriam no local onde o vidente estivesse - em sua casa, na maioria dos casos. Entretanto, a partir de seis de Março de 1993, segundo ele, Maria lhe avisa que passaria a vir todos os dias, por volta das dezoito horas e trinta minutos. É neste período também que “Ela” avisa que começará a aparecer no “Monte”. 
O "Monte” é uma localidade próxima à casa de Marcos, na Zona Rural de Jacareí. Trata-se de uma montanha como qualquer outra da região, sem nenhuma característica especial, um local ermo, deserto e de difícil acesso. Neste local, posteriormente, teve início a construção de um Santuário dedicado a Nossa Senhora.

Novamente aqui percebemos a aproximação com as aparições modernas. As aparições de Lourdes, Fátima e La Salette também ocorreram em lugares desertos, na zona rural, para crianças pastoras que estavam cuidando do gado. Esta é uma característica do modelo de aparições presente a partir da segunda metade do século XIX, e que difere das manifestações da Idade Média, que aconteciam em capelas ou mosteiros, em lugares fechados, e não em meio à natureza como as três aparições mencionadas. Em Lourdes a Virgem aparece em uma grota, em Fátima na "Cova da Iria”, e seus Santuários foram construídos no exato local onde, segundo o relato dos videntes, Maria lhes aparecia - em Lourdes houve a construção da catedral sobre a rocha da grota onde Bernadette dizia ver Nossa Senhora, sendo que no ponto exato da aparição há uma imagem reproduzindo a Virgem; em Fátima a Catedral foi construída ao lado da Azinheira sobre a qual Maria aparecia para os três pastores.

Dessa forma, a transferência do lugar das aparições para uma montanha busca uma aproximação com importantes manifestações marianas. Por meio dela, criase uma história semelhante ao modelo que obteve sucesso nas aparições européias apoiadas pela Igreja - a localidade deserta, próxima da natureza.

A mudança no local das manifestações ocorre no momento em que o número de peregrinações para Jacareí aumenta devido à intervenção do movimento carismático - lideranças da RCC entram em contato com o vidente, se apropriam da manifestação e começam a divulgá-las por meio de suas redes. Nesse período sendo Marcos ainda um adolescente, os grupos carismáticos dão o tom das manifestações sendo que o novo local para as aparições é estabelecido por intermédio dos membros da RCC $^{55}$. Notamos novamente que essas semelhanças são implantadas em Jacareí ao longo do tempo, não estando presentes em um primeiro momento.

\footnotetext{
${ }^{55}$ Entretanto, não possuímos muitos dados sobre este período, pois o vidente, alguns anos depois, rompeu com os carismáticos, não nos dando indicações sobre as pessoas envolvidas. As informações obtidas foram através de conversas com os participantes atuais, mas estes não conheceram os carismáticos, pois ainda não participavam das manifestações nesta época, apenas sabem um pouco do que aconteceu, como a apropriação dos Cenáculos pela RCC e a posterior ruptura entre o vidente e o movimento.
} 


\section{B) O ponto da aparição}

Há um local específico no Monte onde os peregrinos acreditam que Nossa Senhora se manifeste, é o ponto em que Marcos diz ver Maria. Este espaço fica ao lado da capela, e a entrada dos peregrinos é proibida. Somente as pessoas autorizadas, pertencentes ao grupo de apoio, têm acesso a ele.

A existência de um local específico no Santuário em que a Virgem se manifesta é também uma característica recorrente nas aparições reconhecidas. Lembramos os Santuários de Lourdes e de Fátima, por exemplo. Em Lourdes, segundo a crença, Nossa Senhora apareceu para Santa Bernadette em uma grota, e este local tornou-se ícone de devoção para os peregrinos. A imagem da Virgem de Lourdes foi colocada no local exato da aparição, e a passagem diante dela, tocando, beijando o ponto em que acreditam que a Virgem esteve presente é parte central da visita ao Santuário - diante da grota foram colocados vários bancos, em que os peregrinos passam horas orando e pedindo graças para Nossa Senhora de Lourdes.

Em Fátima, segundo os relatos, Nossa Senhora apareceu para os pastores sobre uma azinheira. Esta árvore também possui uma conotação importante para os peregrinos - todas as suas folhas e galhos foram arrancados por eles, como uma relíquia. No local foi plantada uma nova azinheira, diante da qual os peregrinos realizam suas orações. Entretanto, embora lembre o local em que a Virgem esteve presente, não se trata de um ponto central para os peregrinos - como a grota em Lourdes - pois a árvore original, aquela que acreditam ter sido tocada por Nossa Senhora, não existe mais, ou seja, o ponto exato com o qual Maria esteve em contato desapareceu, justamente devido à devoção dos peregrinos anteriores, que quiseram levar consigo uma folha, um galho, ou seja, uma parte do que fora tocado pela Virgem.

Em Jacareí também o espaço "tocado por Nossa Senhora" possui uma importância especial, entretanto, esta relevância é atribuída pelo vidente e pelos integrantes do grupo de apoio, que restringem o acesso ao local. Os peregrinos não se importam muito com esta restrição, não há, como em Fátima e Lourdes, manifestações de desejo ou ressentimento por não poderem estar em contato com o espaço que acreditam ter sido tocado por Nossa Senhora.

Há, pois, uma ambigüidade no que se refere à importância atribuída a esse local. Para os responsáveis pelo Cenáculo - vidente e grupo de apoio - ele é central, não devendo ser tocado por “qualquer um”. Para os peregrinos ele é um espaço sem maior 
relevância. Os integrantes do grupo de apoio, por estarem mais envolvidos com o fenômeno e por possuírem um maior conhecimento sobre aparições marianas, consideram este ponto como sagrado, devendo ser preservado - fazem referência à grota de Lourdes e a árvore de Fátima, lembrando a sacralidade dos locais “tocados” por Maria. ${ }^{56}$

Já no caso dos peregrinos há uma indiferença sobre este local, embora acreditem ser um local “tocado” por Nossa Senhora. Isso ocorre porque, diferentemente de Lourdes e Fátima, as aparições de Jacareí continuam acontecendo mensalmente. Dessa maneira, estão lá no mesmo momento que a Virgem. Essas pessoas sempre mencionam a importância de "estarem lá” no dia do Cenáculo, ou seja, no mesmo dia e no mesmo horário que Nossa Senhora. Assim, o local tocado pela Virgem não possui a centralidade dos Santuários da modernidade devido à simultaneidade no tempo/espaço. Trata-se do mesmo espaço - o Santuário - e o mesmo tempo - ao meio dia dos segundos domingos. Nos Santuários marianos citados anteriormente isso não é considerado possível, pois as aparições deixaram de acontecer há muitos anos, sendo que o espaço tocado por Maria é o que resta da sua presença no Santuário.

Dessa forma, a especificação de um lugar para as manifestações da Virgem demonstra novamente o funcionamento da operação de modelagem. O vidente e os integrantes do grupo de apoio têm conhecimento da centralidade do ponto tocado pela Virgem nos Santuários marianos, e, ao construírem o Santuário de Jacareí, estabelecem um ponto exato para a manifestação, procurando atribuir valor especial a ele. A importância deste ponto no Monte é recente - desde 2006, por iniciativa do vidente segundo Marcos, Maria passou a se manifestar ao lado esquerdo da capela recém construída, e "pediu” para restringir o acesso ao local.

Assim, a proibição do contato dos peregrinos com o local da aparição, além de demarcar o poder do grupo de apoio, coloca em evidência este espaço e o valoriza. Ou seja, ao impedir a permanência dos peregrinos neste local, destaca que ele não é um ponto como os de mais do Santuário, mas sim é o espaço tocado por Nossa Senhora. Com isso modelam simbolicamente o Santuário a partir dos padrões presentes nos grandes Santuários de aparições marianas.

\footnotetext{
${ }^{56}$ Além disso, esta é também uma forma de demarcação de espaços de poder, pois apenas os iniciados, ou seja, as pessoas que possuem um envolvimento maior com as manifestações - e não os peregrinos que apenas participam mensalmente dos Cenáculos - podem estar em contato com o ponto exato em que Nossa Senhora se manifesta.
} 
Há, porém, uma ambigüidade em relação às manifestações marianas contemporâneas no que se refere à questão do espaço. Atualmente as aparições acontecem onde o vidente estiver - esta é uma característica presente na aparição de Medjugorje e que se repete em Jacareí e em outras manifestações de Nossa Senhora no Brasil, como demonstramos no primeiro capítulo. Apesar disso, a importância da construção de um Santuário, de um local específico para a realização dos Cenáculos ainda se faz presente, como fica claro no caso analisado. Ou seja, apesar da circulação de Marcos Tadeu por paróquias da região e de sua peregrinação para outros locais de aparição, tendo visões e realizando a peregrinação da própria Nossa Senhora, a existência de um Santuário, que segue as características dos Santuários marianos europeus ainda é uma característica marcante deste fenômeno.

As aparições contemporâneas possuem Santuários, como é o caso de Medjugorje. Apesar da circulação de seus videntes, a vila na Bósnia tornou-se um Santuário de peregrinações, como demonstrado por Claverie (2003) em seu estudo sobre estas aparições. Outras aparições brasileiras, como a de Piedade das Gerais, analisada por Almeida (2004), também são marcadas pela circulação das videntes e pela formação de um Santuário no local. Assim, embora a circulação das manifestações seja uma característica importante das aparições contemporâneas, a construção de Santuários nestes locais não pode ser considerada secundária - eles são destinos de numerosas peregrinações. Esse tema foi detalhado em capítulo anterior. Aqui devemos destacar apenas que os Santuários contemporâneos são espacial e simbolicamente construídos de acordo com o modelo de Santuário das aparições modernas.

\section{C) A fonte}

No "Monte" escolhido por Nossa Senhora, segundo os devotos, existe um pequeno riacho, que mal chega a ser um córrego, que corta o local. A água deste córrego é considerada miraculosa, e os freqüentadores a consomem durante os Cenáculos e a levam para suas casas, oferecendo-a para pessoas que precisam de "graças".

Há uma série de relatos sobre o poder milagroso deste água, considerada capaz de curar males físicos e espirituais. Cito o exemplo de uma senhora, de São Paulo, que afirma ter superado a depressão após a morte de seu marido devido à água de Jacareí, por isso vai todo mês ao Cenáculo para “ver Nossa Senhora” e leva um recipiente da água para sua casa, bebendo um pouco a cada dia e deixando uma reserva 
constante para amigos, familiares e conhecidos que eventualmente possam precisar. A água pode ser oferecida para curar todo e qualquer mal, desde um simples resfriado até alcoolismo e desemprego. Uma outra peregrina relata que conseguiu curar seu genro, que estava "perdido na bebida” fazendo-o beber um pouco a cada dia da água de Jacareí. E o rapaz, mesmo sem ter conhecimento de que bebia da “água milagrosa”, acabou por se curar, abandonando o álcool. Estes são apenas dois exemplos dos “milagres e curas” que a água de Jacareí é capaz de realizar. Devido à crença em seu poder é comum observarmos vários peregrinos, no dia do Cenáculo, com recipientes vazios, que serão utilizados para levar a água do Santuário.

A presença da água e a atribuição de poder milagroso a ela nos remete a uma das aparições marianas mais conhecidas no catolicismo: Lourdes - o Santuário mariano mais visitado no mundo. Em Lourdes, segundo a história, Maria aparece para Santa Bernadette em uma grota e, em uma das aparições lhe mostra uma mina d'água que diz ter poder de cura de todos os males. Desde então a água de Lourdes adquire centralidade no Santuário, sendo que desde o século XIX os peregrinos tomam a água e banham-se nela - no local foram instaladas torneiras e piscinas utilizando a água da fonte.

A crença no poder de cura da água de Lourdes é de grande importância no Santuário, sendo que inúmeras pessoas realizam a peregrinação para se banharem nas piscinas, acreditando que obterão a cura após a imersão nestas águas. Os peregrinos também levam a água para suas cidades de origem, para oferecer aos amigos e parentes e para usá-la em alguma eventualidade ou urgência. Os relatos de milagres realizados pela água são inúmeros, reconhecidos e não reconhecidos, estando presentes desde os primeiros anos do Santuário.

Lourdes é o Santuário mariano com o maior número de milagres reconhecidos - sessenta e oito - graças ao cuidado dos administradores na coleta dos relatos de curas, de dados médicos e testemunhos associados a elas, sendo tudo fartamente documentado e organizado em forma de dossiês. Interessa destacar que a maioria destes milagres tem relação com a “água de Lourdes”.

A história e os relatos presentes em Jacareí são semelhantes aos presentes em Lourdes. Além da aparição ocorrer em um local ermo, junto da natureza, há a presença de um riacho, ao qual é associado um poder milagroso, sendo que a forma de utilização da água, bem como os relatos de curas também são semelhantes. Nos dois Santuários os peregrinos bebem da água e a levam para casa, para si e para os conhecidos, acreditando que ela lhes trará benefícios. Como em Lourdes, não é preciso 
que a pessoa doente vá ao santuário; há relatos de milagres em que a cura ocorreu apenas por beber a água transportada por algum peregrino, como os casos mencionados anteriormente.

O Santuário francês está muito melhor estruturado em torna da utilização da água do que Jacareí. Há piscinas, e garrafas reproduzindo a imagem da Virgem são vendidas em todo o Santuário, para que os peregrinos possam transportar a "água milagrosa”. Já em Jacareí tudo ainda é improvisado, sendo que os peregrinos bebem a água diretamente do córrego e trazem garrafas de plástico para transportá-la. Entretanto, as torneiras já estão colocadas - embora ainda não funcionem - e há uma piscina para ser instalada; ou seja, a reprodução do padrão de Lourdes não está apenas no uso da água, mas na própria estruturação física do Santuário. Em Jacareí o uso milagroso da água é, pois, um elemento a mais na modelagem do Santuário. É interessante notar que a menção a água não estava presente nos relatos dos primeiros anos das aparições, sendo apenas a partir da transferência do local dos eventos que ela passa a ser referida pelo vidente e utilizada pelos fiéis.

Dois atores se destacam como únicos na modelagem das aparições de Jacareí: os carismáticos e o vidente. Nos primeiros anos da aparição, quando Marcos é ainda um adolescente, grupos carismáticos da região, principalmente de São José dos Campos, se apropriam do fenômeno e o reorganizam. Eles são os responsáveis pela escolha do local para o Santuário, bem como pela elaboração do relato sobre as aparições, que mais tarde é publicada em livros e CDs, tornando-se a versão "oficial” sobre as manifestações, hoje reproduzida pelos participantes e pelos integrantes de Jacareí - vidente e grupo de apoio. Por volta de 2001, quando Marcos já é um jovem adulto, ocorre a ruptura com o movimento carismático. A partir de então o vidente passa a exercer a liderança absoluta sobre a aparição, sendo acompanhado por um pequeno grupo de pessoas, que não possui vínculo com nenhum movimento da Igreja. Neste momento Marcos já tem conhecimento e contato com outras manifestações marianas no Brasil, bem como já realizou a peregrinação para os Santuários marianos europeus. A partir de então a modelagem das aparições passa a ser realizada pelo próprio vidente, que não admite interferências sobre as suas "ordens", sempre atribuídas a Nossa Senhora - como nos casos da atribuição de poder milagroso à água e a escolha de um ponto específico para as aparições. 


\section{D) O cruzeiro}

No monte das aparições existe um cruzeiro, localizado no alto de uma montanha em frente ao local em que está sendo construída a capela. Há duas montanhas no Santuário, uma onde está a capela e a outra, bem mais alta, onde se encontra o cruzeiro. Este local é utilizado pelos peregrinos para o "pagamento de promessas", ou seja, vários fiéis realizam promessas para Nossa Senhora, para que consigam obter alguma "graça”, como cura de doenças, emprego, entre outros. Caso a graça seja obtida eles devem subir o morro do cruzeiro.

Esta característica novamente aproxima o Santuário de Jacareí dos Santuários Marianos reconhecidos, em que há um local específico para o pagamento de promessas. O exemplo de Fátima é o mais importante e impactante, pois logo na chegada do Santuário há uma enorme esplanada, diante da capela, que é atravessada de joelhos pelas pessoas que acreditam ter obtido alguma graça de Nossa Senhora. Todos os dias há dezenas de pessoas pagando suas promessas na esplanada de Fátima. Em Lourdes também há uma montanha, que reproduz a via crucis, subida pelos pagadores de promessa - como em Lourdes o Santuário é bastante institucionalizado, houve uma aproximação entre o sacrifício dos peregrinos e o sacrifício de Jesus Cristo ao subir o Monte das Oliveiras. Já em Fátima a tônica está no sacrifício humano, desde o primeiro momento há o impacto da capela e sua esplanada repleta de pessoas se arrastando de joelhos. Dessa maneira, se em Lourdes a ênfase do Santuário encontra-se no poder milagroso da água, em Fátima o sacrifício é o elemento central ${ }^{57}$.

Entretanto, devemos destacar que a crença na necessidade de retribuição das graças obtidas por meio de sacrifícios não é uma característica presente apenas nos Santuários Marianos; pelo contrário, trata-se de uma prática muito recorrente no catolicismo, sendo que na grande maioria dos Santuários existe algum local utilizado pelos peregrinos para realizar seu sacrifício.

Lembramos o estudo realizado por Steil (1996) sobre o Santuário do Bom Jesus da Lapa, em que a própria realização da peregrinação é considerada pelos fiéis como o cumprimento da promessa, ou seja, o deslocamento até o Santuário é um sacrifício, devido a todas as dificuldades que se sucedem - a viagem de caminhão, dormir ao relento, cozinhar ao ar livre - tudo é percebido como um grande sacrifício

\footnotetext{
${ }^{57}$ A ênfase no sacrifício está em parte relacionada com a crença na escatologia, na proximidade do Juízo final, por isso ele é mais presente e evidente em Fátima, onde os elementos escatológicos eram centrais nas mensagens de Maria, do que em Lourdes, em que a enfase encontra-se na cura e nos milagres, sendo que a escatologia não faz parte dos elementos simbólicos desta aparição.
} 
realizado em troca de alguma graça recebida do Bom Jesus ${ }^{58}$. Toda peregrinação é estruturada em torno da promessa e do seu pagamento, sendo a reciprocidade chave nas peregrinações do catolicismo popular.

Nos dois Santuários marianos mencionados também ocorre a institucionalização do sacrifício. Ambos são desde a sua fundação administrados por ordens religiosas e possuem práticas bastante institucionalizadas, ou seja, há uma adequação à doutrina católica que procura evitar “exageros”. Ora, apesar do sacrifício não ser um elemento estranho ao catolicismo, a sua utilização deixou de ser enfatizada pela Igreja - embora tenha permanecido nas práticas populares da religião. No caso dos Santuários de Lourdes e Fátima houve a institucionalização de uma prática típica da religiosidade popular, que acabou sendo integrada a eles - em Fátima, por exemplo, a esplanada foi impermebializada, de forma a diminuir as dores dos pagadores de promessa, mantendo-se a crença, mas sem enfocar as dores físicas da promessa.

A colocação do cruzeiro no Santuário de Jacareí, transformando a colina no local dedicado pelos peregrinos para o pagamento de suas promessas com a Virgem, nos remete para práticas religiosas profundamente arraigadas no catolicismo brasileiro, como as promessas e devoção aos Santos - no caso, a Nossa Senhora.

Nesse sentido, procuramos mostrar que embora a promessa e o seu cumprimento não sejam centrais nas peregrinações contemporâneas; elas não estão, no entanto, ausentes nestes fenômenos, sendo definido, inclusive, um local específico para a sua realização, embora secundário. Além disso, a peregrinação propriamente dita não é percebida como um sacrifício ou uma obrigação com a Virgem, característica central das peregrinações do catolicismo popular.

\section{3) O Vidente}

Para que os fenômenos fossem percebidos como legítimos era preciso que o vidente também o fosse. Dessa forma, simultaneamente a modelagem das aparições foi sendo realizada a modelagem do vidente. Por isso a importância das características e valores do vidente, pois são elas que lhe atribuem raridade.

O vidente tem que ser percebido como dotado de valor e raridade para que possa transferir raridade e valor para seu produto - as suas visões. Desde o início das

${ }^{58}$ A importância da peregrinação no catolicismo popular e a sua percepção como uma forma de retribuição ao santo foi analisada no capitulo anterior. Neste item importa destacar a existência do cruzeiro no Santuário de Jacareí, e o seu uso para o pagamento de promessas dos peregrinos, de forma semelhante às praticas da religiosidade popular e também dos Santuários marianos europeus. 
manifestações alguns valores do vidente são destacados, como a humildade e a inocência - estes são dois valores importantes nos videntes de Nossa Senhora - sendo considerados atributos que demonstram que a pessoa foi um “escolhida” de Maria, ou seja, é um vidente legítimo.

Como sugere Bourdieu, para que um criador atribua raridade a um produto ele próprio tem de ser percebido como raro. É a raridade do criador que faz a raridade do produto. Ou seja, "produzindo a raridade do produtor que o campo da produção simbólica produz a raridade do produto” (1975:21). Assim, a excepcionalidade do vidente também deve ser produzida para que a aparição seja considerada verídica.

A figura central das aparições, além de Nossa Senhora, é o vidente - pessoa considerada “escolhida” pela Virgem para receber as suas mensagens. Como observado em relação ao Santuário, há também características do vidente que são importantes para a atribuição de legitimidade à aparição e ao próprio vidente. Analisando as falas dos participantes sobre Marcos constatamos que as características que eles ressaltam estão relacionadas à sua personalidade - de pessoa "humilde" e “inocente" - e a sua história de vida - marcada por sacrifícios e provações, e sem pecados. Assim, para o vidente ser considerado legítimo - e não um farsante, mentiroso, charlatão, louco - ele deve convencer o público da veracidade do evento, sendo que a história de sua vida e suas características pessoais constituem parte importante desse processo de legitimação.

Estes elementos - a história do vidente e sua personalidade - também são levados em conta no processo de reconhecimento da Igreja. A história de vida é significativa antes, durante e após os eventos. Antes, porque ele deve demonstrar possuir os valores que levaram a Virgem a "escolher" aquele indivíduo, sendo que a "humildade” e a "inocência” do vidente são importantes. Durante porque o vidente deve provar sua sanidade mental - são visões, e não alucinações - e seu não charlatanismo pela ausência de interesses financeiros. Após, pelo chamado "testemunho de vida”, ou seja, o vidente deve ter uma postura considerada correta pela Igreja, demonstrando a presença do contato divino em sua pessoa por meio de uma conduta "exemplar”.

Nesse sentido, a aproximação com as aparições modernas é novamente notada, pois as características mencionadas são observadas nos videntes das aparições reconhecidas. Os atributos destacados de Marcos são semelhantes aos destacados nos videntes do final do século XIX e início do século XX. Devemos, pois, analisar cada uma destas características importantes para a excepcionalidade do vidente frente aos devotos e à instituição. 


\section{A) A Inocência e a Humildade}

A "humildade” e a "inocência” de Marcos Tadeu são duas características constantemente reiteradas pelos participantes. A humildade é demonstrada, para eles, pela sua situação econômica - sendo originário das camadas populares - e pelo fato de não possuir um grau elevado de educação formal, especialmente no momento da primeira aparição de Nossa Senhora.

A “inocência” também está relacionada a pouca educação formal do vidente durante as primeiras manifestações, bem como a sua juventude neste período - ele tinha treze anos em 1991, quando ocorreram as primeiras visões - sendo ambas consideradas como "provas" da sua inocência, ou seja, de sua incapacidade em manipular ou inventar as aparições.

Estas duas características - a inocência e a humildade - são consideradas importantes para a "escolha” feita por Nossa Senhora. Na percepção dos devotos, Marcos era um jovem comum, pobre, humilde, inocente, e justamente por ser tão comum, por possuir as mesmas características que vários outros adolescentes da sua idade - sem possuir nada de "especial”, nada que o colocasse em destaque - ele é escolhido por Maria para ser o intermediário de suas mensagens.

Ou seja, a excepcionalidade do vidente se funda justamente em não ter nada de especial, em ser mais um jovem pobre e sem instrução. No entanto, é um jovem pobre e humilde que aceita a missão de divulgar as mensagens transmitidas pela Virgem, e todas as provações, sacrifícios e perseguições conseqüentes desta tarefa. Assim, apesar das características que o enquadram como "mais um", sem nada de especial, a perseverança e fortaleza do vidente em cumprir a sua missão são também destacadas.

Os traços de personalidade de Marcos - humildade e inocência, mas acompanhadas da fortaleza e perseverança, fundamentais para que divulgue as mensagens de Maria - nos remetem à outra vidente mariana, já canonizada: Santa Bernadette, a vidente de Lourdes. Segundo Ruth Harris, a simplicidade e a pobreza de Bernadette são essenciais para o seu reconhecimento pelo povo. Em suas palavras "sa simplicité, son regarde direct, son patois faisaient partie integrante du message de notre dame de Lourdes. En la choisissant, la Vierge avait distingué les pauvres et les ignorants." (2001:195). 
Entretanto, apesar da ignorância extrema de Bernadette - considerada prova de sua inocência -, ela era muito forte, tendo passado por várias provações - como xingamentos e desprezo por parte das autoridades locais e dos padres e bispos - mas persistindo em seu relato. Assim, como Bernadette, as virtudes destacadas de Marcos Tadeu estão relacionas a sua humildade e inocência. No entanto, também como a vidente de Lourdes, apesar de humilde, ele é forte, sendo capaz de superar as várias provações para persistir em sua fé.

Pobreza, simplicidade, juventude, inocência - todas estas características estão associadas aos videntes desde as aparições do final do século XIX. Em La Salette, Pontmain, Lourdes, Fátima, Garabandal e Medjugorje os videntes eram crianças ou adolescentes pobres, quase sempre pastores, que estavam em localidades isoladas pastoreando o gado. Os carismáticos presentes nos primeiros tempos das manifestações sabiam disso, bem como Marcos e os participantes do grupo de apoio o sabem atualmente. Assim, quando enfatizam estas características de Marcos Tadeu em seus relatos, destacam valores considerados importantes nos videntes reconhecidos, e que constituem a sua raridade. Ao destacarem os mesmos valores no jovem de Jacareí, estão demonstrando a sua raridade, que justifica o fato dele ter sido “escolhido” por Maria.

Além disso, estes valores dos videntes são muito semelhantes aos apresentados por Nossa Senhora durante a anunciação - momento em que ela é “escolhida” por Deus para gerar o seu filho. Por um lado, ela é retratada como muito jovem neste período, sendo de origem humilde. Por outro lado, esse é o momento em que ela diz sim ao Senhor, aceita o plano divino com todas as suas dores e sofrimentos.

De forma semelhante à Maria, os videntes são jovens e humildes no momento em que dizem sim à aparição, em que aceitam a missão de divulgar a mensagem da Virgem e se empenham em cumpri-la - como o sim de Nossa Senhora, o sim de Marcos também não representa a passividade, mas a atividade, a perseverança e a fortaleza em cumprir os desejos de Nossa Senhora mesmo diante das dificuldades enfrentadas. Além disso, assim como Maria, a jovem humilde escolhida pelo senhor, Marcos é apenas mais um, ele não se destaca, não aparenta ter nada de especial.

Marcos possui, pois, características pessoais semelhantes aos demais “mensageiros de Deus”, desde a mais iminente delas - Nossa Senhora - até os videntes marianos desde o século XIX. Isso permite que os peregrinos reconheçam nele traços de santidade, comprovando a sua raridade, fundamental para a produção da verdade da crença nas suas visões. 
B) A vida de provações: a importância da perseverança

As provações pelas quais Marcos Tadeu teve de passar desde a sua infância são sempre destacadas nos depoimentos sobre a sua vida. O seguinte relato, presente no livro "Maria nas aparições de Jacareí” ilustra bastante bem a centralidade dada às dificuldades do vidente ao longo de sua vida. Este relato está no item "Maria escolhe um jovem”, dedicado à descrição de Marcos:

\footnotetext{
“Quando pequeno tinha um problema de sopro no coração. O pai, desde os quatro anos de Marcos, começou a beber, causando grande sofrimento para a família. Seu pai era um homem violento, e quando bebia chegava a bater nele e em sua mãe. Quando tinha de nove a dez anos o pai o abandonou, com a o irmão, sozinhos. Para que não passassem necessidade sua mãe trabalhou arduamente. Mesmo assim, nunca foi revoltado, nem teve dificuldades escolares, sempre tirando boas notas. Em 1986 teve sarampo e quase morreu, ficando quatro dias inconsciente”. (2000:11)
}

Podemos notar, nesta primeira parte da descrição da infância de Marcos, que apenas os sofrimentos e dificuldades passados pelo vidente e por sua família são relatados. O tom de provação persiste durante todo o item, valorizando mesmo dores aparentemente simples - como um pequeno problema no joelho. No livro mencionado, há dois momentos que relatam as provações: o primeiro deles menciona as provações passadas pelo jovem na infância, e o segundo momento os sacrifícios dedicados a Jesus, iniciados após as visões. Assim, qualquer pequeno transtorno vivenciado pelo vidente é relatado de forma a valorizá-lo como uma provação ou um sacrifício.

Além dos sofrimentos físicos, os relatos dos participantes também destacam as “perseguições”. Segundo eles, Marcos passou por “perseguições” de diferentes origens: pela diocese de São José dos Campos - que não considera a aparição verídica e submeteu o vidente a exames e entrevistas para constatar a sua sanidade mental -; por parte da população local "que falava mal e rejeitava as aparições. Como outrora em Belém, em que o povo da cidade não quis aceitar o Salvador e a Virgem Santíssima." (2000:35) - os moradores de Jacareí jamais aceitaram as manifestações, considerando Marcos como um farsante e interesseiro, em referência aos supostos benefícios financeiros obtidos por ele com as aparições -; por parte da mídia, que no auge dos 
Cenáculos publicou matérias que indicavam o charlatanismo de Marcos e supostos benefícios financeiros retirados dos rituais -; por parte de grupos evangélicos, que empreenderam “ataques” ao vidente, por agressões verbais e ameaças físicas.

O relato da vida de Marcos destaca as provações, sacrifícios e perseguições passados por ele desde a sua infância até os dias de hoje. Este relato, elaborado pelos carismáticos envolvidos com as manifestações em seus primeiros anos, foca as dificuldades da vida do vidente, repetindo o padrão de relatos de vida de videntes.

A vida da vidente Bernadette, de Lourdes, é um relato de referência. Ela teve uma infância muito pobre e conturbada, marcada pela fome, e, depois, com as aparições foi humilhada pelos habitantes locais e por alguns representantes do clero, até o momento do reconhecimento, após o qual se recolhe em um convento. Porém, mesmo com o fim das “perseguições” e da pobreza extrema, sua saúde continuou muito frágil, levando-a ao falecimento precoce. A vida dos videntes de Fátima, três pastores, é também relatada como pobre e humilde, sendo repleta de "provações", tanto que dois deles - Jacinta e Francisco - morrem ainda durante a infância.

Assim, a ênfase nos sofrimentos e na rejeição assemelha a história de vida de Marcos a de outros videntes marianos ${ }^{59}$. - inclusive pelo destaque a seus problemas de saúde, nunca muito graves, mas intensamente sublinhados, aproximando-os dos males físicos sofridos por outros mensageiros - de forma a legitimar sua veracidade. A ênfase nas provações e sacrifícios torna patente a proximidade entre a vida dos videntes, inclusive de Marcos Tadeu, e a vida de Jesus, pois ambas são marcadas por provações a serem superadas, sacrifícios corporais dedicados a Deus - Jesus passou pela dolorosa via crucis; Marcos sofreu dores físicas, doenças, internações, todas elas interpretadas como sacrifícios pedidos por Deus e realizados de bom grado pelo vidente - e perseguições por parte de diversos setores da população - foi o povo que condenou Jesus a crucificação, além de outras perseguições passadas por ele e os apóstolos durante sua vida, Marcos também destaca as várias perseguições sofridas desde o inicio das aparições.

A ênfase nos sofrimentos físicos de Marcos, em suas doenças, é uma maneira de comprovar a sua "santidade", por meio da aproximação dos sofrimentos de Jesus e de outros videntes de Nossa Senhora. Assim, o relato da vida de Marcos Tadeu é

\footnotetext{
${ }^{59}$ Apenas alguns episódios de felicidade e satisfação são narrados, como a sua visita aos Santuários Marianos europeus - Fátima, Lourdes e Medjugorje. Entretanto, mesmo os momentos felizes citados servem para atribuir legitimidade ao vidente, pois se referem à sua peregrinação aos Santuários Marianos de aparição mais visitados na contemporaneidade.
} 
construído de forma a atribuir legitimidade e raridade ao vidente pela aproximação entre a sua vida e a vida de Cristo e de outros santos.

\section{C) O testemunho de vida}

A vida seguida pelo vidente após as aparições também é utilizada como evidência da veracidade das aparições. Aliás, o que mais se poderia esperar de uma pessoa que viu e conversou com Nossa Senhora? Que siga uma vida "santa”, "sem pecados”, ou seja, de acordo com a conduta considerada correta pela Instituição Católica, ou instituída pela Virgem. A conduta dos videntes é importante e possui lugar central na análise sobre a veracidade das aparições por parte da Igreja. Além disso, ela serve como fonte de legitimação para estes fenômenos ${ }^{60}$.

A análise da postura do vidente foi instituída pela Igreja ainda na Idade Média, momento em que ela, segundo Barnay, busca retirar o foco das visões e dos transes e centrar-se nos videntes, nas pessoas que tiveram contato com a Virgem Maria. Eles passam a ser chamados "exempla”, ou seja, os visionários deviam ser pessoas exemplares por meio da imitação da Virgem Maria, assim, eles próprios se tornariam modelos para a cristandade. A Igreja busca exercer o controle sobre as visões por meio do controle dos videntes, transformando-os em exemplos de vida. Essa forma de agir da Igreja Católica em relação aos videntes não sofreu grandes alterações nas aparições modernas e nas aparições contemporâneas, sendo que ainda hoje um dos principais critérios determinados pelo Vaticano para o reconhecimento de uma aparição é a análise do comportamento do vidente. Quanto mais alinhado com a doutrina católica, maiores as possibilidades de reconhecimento, especialmente quando eles se tornam exemplos para os demais cristãos, optando pela vida religiosa, como fizeram as videntes Lucia vidente de Fátima - e Bernadette - vidente de Lourdes.

No caso de Jacareí, mesmo diante do combate realizado pela diocese às aparições, o vidente busca ter uma vida "exemplar", afastada do mundo de pecados. Nesse sentido, ele institui regras mais rígidas do que as presentes na Igreja após o Concilio Vaticano II $^{61}$. O vidente se veste com uma batina marrom, como a dos franciscanos, não freqüenta festas, bares e restaurantes, não namora, não acumula

\footnotetext{
${ }^{60}$ No capítulo sobre o papel da Igreja nas aparições demonstramos como o Pe Laurentin constrói a legitimidade das aparições de Pontmain a partir do testemunho de vida exemplar de seus videntes.

${ }^{61}$ Isso tem relação com as críticas ao clero e a Igreja, comuns nas crenças escatológicas e nas concepção do mundo como local do pecado, como analisaremos no capitulo seguinte.
} 
riquezas - fez voto de celibato e de pobreza. Ou seja, segue uma doutrina muito rígida que o afasta do "mundo" considerado pecaminoso.

Entretanto, se os valores do vidente bastavam no início das manifestações, quando ele ainda era uma criança, com o passar do tempo apenas o seu caráter extraordinário não era suficiente, ele devia também ser inserido no campo como agente, adquirindo conhecimento e contato com outras manifestações, de forma a acumular o capital simbólico necessário para manter a sua legitimidade. Marcos, por exemplo, realizou inclusive a peregrinação para os Santuários marianos europeus - Fátima, Lourdes e Medjugorje. O vidente acumula capital simbólico pelo contato e conhecimento sobre as aparições reconhecidas. Além disso, Marcos, com o passar do tempo, consegue se mostrar detentor deste capital de autoridade, sendo que, na segunda década das aparições ele é o detentor exclusivo da palavra durante os Cenáculos, realizando orações, pregações e interpretações das mensagens de Nossa Senhora, sendo capaz de realizar citações sobre outras manifestações e conexões entre as mensagens da Virgem, demonstrando amplo conhecimento sobre elas. Ou seja, neste período ele passa de mero receptáculo das mensagens para intérprete exclusivo delas, analisando-as e estabelecendo conexões entre elas e mensagens da Virgem em outros locais.

Demonstraremos a seguir que as atitudes tomadas por Marcos neste período o afastam do padrão estabelecido para as aparições e para seus videntes, causando a ruptura com importantes membros da rede de manifestações marianas.

\section{4) A Retração das Aparições}

Neste item analisaremos a segunda década das aparições, a partir de 2002, momento em que os Cenáculos entram em declínio, diminuindo significativamente o número de participantes. Consideramos que este esvaziamento ocorreu devido a dois fatores: o isolamento do vidente e o seu afastamento do modelo de aparições reconhecidas. Desde o início das manifestações ele não foi aceito pelo bispo da diocese, sendo posteriormente combatido por ele e, em seguida pelos sacerdotes locais. Entretanto, o seu isolamento ocorreu principalmente em relação à comunidade católica de Jacareí e das cidades próximas e a figuras importantes da RCC no Vale do Paraíba que, na primeira década, constituíram a sua base de apoio.

Quando encerramos nosso trabalho de campo o vidente encontrava-se isolado, apoiado apenas por um pequeno grupo de participantes fixos, responsável pela 
organização dos Cenáculos, que a cada mês estava mais esvaziado. Neste momento quase não havia “novos” peregrinos, a grande maioria era de participantes fixos, vindos de outras localidades, mas que já conheciam a aparição e a freqüentavam com certa regularidade. Ou seja, a aparição estava estagnada devido à rejeição do vidente na comunidade religiosa local - clero e católicos da região -, e a sua ruptura com o movimento carismático. Analisamos esta teia de relações, que a princípio contribuiu para a legitimidade das manifestações, mas, que também se mostrou central para a estagnação posterior dos rituais.

A perda de apoio está relacionada à perda da autenticidade de suas visões, elas não são mais percebidas como verídicas pelos carismáticos e pela comunidade local; ou seja, eles não têm mais convicção na sacralidade dos fenômenos. Isso ocorre porque Marcos rompe com o padrão das aparições reconhecidas - no que se refere à simbologia e as características de sua personalidade. Ele insere novos elementos e realiza ações que, na percepção dos peregrinos, não condizem com uma aparição verídica e um vidente autêntico.

\section{1) A ruptura com os carismáticos}

A ruptura entre o vidente e os carismáticos da região ocorre no final do ano de 2001, exatamente uma década após o início dos fenômenos. Vários fatores contribuíram para isso. Marcos já possuía contatos e informações sobre aparições marianas, e começou a questionar o “domínio” dos carismáticos sobre os Cenáculos, argumentando que ele era o vidente, ele era "o escolhido de Nossa Senhora” e, portanto, ele deveria decidir o encaminhamento do ritual.

Paralelamente, os carismáticos o acusavam de "querer aparecer mais do que Nossa Senhora”. Esta frase foi proferida por duas carismáticas, de grupos distintos e em ocasiões diferentes, buscando demonstrar a arrogância do vidente, ou nos termos das informantes, a sua "vontade de aparecer".

Assim, Marcos, ao tentar tomar a frente dos Cenáculos, inicia uma disputa com os carismáticos, que não concordam com a sua liderança. Ou seja, enquanto ele era uma criança e aceitava submissamente as ações e intervenções realizadas pelos carismáticos, a aparição foi intensamente apoiada, divulgada e promovida pelos membros do movimento. No entanto, quando o vidente começa a questionar estas ações, e especialmente ao buscar ser o centro, o foco dos rituais, passou a ser percebido como arrogante e perdeu seu apoio. 
O vidente usa a sua exclusividade como moeda de valorização própria, pois “ele sabia o que a Virgem queria, os outros não”. Como "escolhido de Maria”, afirma que ela lhe atribui tarefas, que somente podem ser realizadas por ele. A mais importante delas - e também a mais polêmica - é a sua exclusividade na interpretação das mensagens de Nossa Senhora. Essa atitude vinha em resposta à organização do livro “As aparições de Nossa Senhora em Jacarế” pelos carismáticos, no qual a sua participação foi mínima - os membros da RCC contaram a história e deram sua interpretação sobre os fenômenos.

O vidente, ao se proclamar como único intérprete legítimo das mensagens da Virgem em Jacareí - passa a organizar mensalmente um CD, com todas as mensagens transmitidas por Maria e com a sua interpretação delas - retira o poder da RCC em relação às “suas” aparições. Além disso, durante os Cenáculos, ele passa a ser o único a ter acesso à palavra. Ele conduz as orações, tem a visão e, por fim, interpreta a mensagem transmitida por Nossa Senhora.

Diante destas atitudes os carismáticos da região rompem definitivamente com Marcos, parando de freqüentar os Cenáculos e depondo contra ele em seus encontros. Importa destacar que o embate entre os carismáticos e o vidente acontece no momento em que os representantes locais da Igreja intensificam o combate às aparições, fato que também dificulta o apoio da RCC que, por ser um movimento católico, precisa, em certa medida, do aval da Igreja. Ou seja, o incentivo às aparições de Jacareí começava a trazer problemas para os carismáticos junto aos representantes do clero local, devido aos “exageros” do vidente.

\section{2) A ruptura com a Igreja}

A aceitação ou a rejeição das aparições pela ortodoxia católica é uma questão que perpassa a história desse tipo de evento. O caminho percorrido para o reconhecimento de uma manifestação de Nossa Senhora pela ortodoxia é bastante longo, entre uma pessoa dizer ter visto e escutado Maria e a aceitação deste fato pela Igreja há um grande caminho a ser percorrido, que, na maioria dos casos, culmina com a sua rejeição ou mesmo com a interdição pelos representantes oficiais do catolicismo.

O número de aparições de Nossa Senhora não aceitos pela Igreja é imensamente maior do que os reconhecidos oficialmente, e mesmo que os apenas “tolerados”. Jacareí é mais um exemplo de rejeição. Atualmente a aparição é completamente rejeitada pelos representantes locais da Igreja Católica, mais 
especificamente pelo bispo de São José dos Campos, responsável pela paróquia em que ocorre a manifestação.

Várias etapas se sucederam até a rejeição: a principio o bispo apenas "não recomendava” a participação dos padres, mas, devido à intensificação da polêmica em torno das atitudes do vidente, o bispo acabou proibindo a presença de sacerdotes no Cenáculo. O pároco de Jacareí acatou sua recomendação e foi ainda mais agressivo, proibindo a participação dos paroquianos, sendo que aqueles que desobedecessem à sua determinação não receberiam a comunhão durante as missas.

Esse é o momento de auge dos debates, que não arrefeceram até o final de meu trabalho de campo, em 2007. É preciso destacar que a proibição estabelecida pelo bispo surtiu efeito sobre o Cenáculo, contribuindo muito para a diminuição do número de participantes nos rituais. Assim, embora não tenha conseguido extinguir o ritual, diminuiu significativamente o número de participantes. Especialmente na diocese de São José dos Campos, a qual pertence Jacareí, a retaliação a essa aparição funcionou, pois atualmente os participantes dos Cenáculos não são provenientes da cidade ou da diocese, mas sim de outras localidades: são os peregrinos analisados no primeiro capítulo.

Segundo a postura determinada pelo Vaticano, uma aparição, para ser rejeitada, deve estar em contradição com elementos da teologia católica. Assim, a postura dos sacerdotes locais está fundamentada nas contradições entre o que é estabelecido pela ortodoxia católica na análise deste tipo de manifestação e a aparição de Jacareí. No capítulo anterior demonstramos que os critérios estabelecidos pelo Vaticano são utilizados de acordo com o interesse dos atores e grupos envolvidos nos eventos. A inserção de “novos” elementos e a postura do vidente contribuem para que a hierarquia percebesse desvios nesta manifestação que a caracterizavam como "falsa” e, portanto, ilegítima.

\section{3) Os "exageros" do vidente e o combate do clero}

As visões de Marcos Tadeu, com o passar do tempo, foram apresentando elementos considerados inconsistentes, sem conexão com a doutrina católica ou com as aparições reconhecidas de Nossa Senhora. Esses elementos surgiram por volta de 1998, no auge das manifestações. Neste período, Marcos, já um garoto de 20 anos, diz receber também a visita de Jesus e de São José, e até mesmo do Arcanjo Gabriel. Todos transmitem mensagens e “confirmam” as falas de Nossa Senhora. Embora a figura 
central das aparições ainda seja Maria, outros santos também começam a aparecer e a falar com Marcos, o que desestrutura o padrão consolidado das aparições: a Virgem não aparece mais sozinha durante os Cenáculos, mas acompanhada de Jesus e de São José.

A inserção destes elementos faz crescer a desconfiança da comunidade e do clero local - que já não via com bons olhos os encontros no Monte. A Igreja inicia, então, um combate contra as manifestações. O principal argumento utilizado por ela é a “inconsistência” das visões de Marcos Tadeu. A diocese e algumas paróquias da região se encarregaram de montar cursos e palestras sobre Nossa Senhora e sobre suas aparições, para "esclarecer" os paroquianos sobre esse tipo de fenômeno. Exemplo disso foi um curso realizado na paróquia do Espírito Santo, em São José dos Campos, na quaresma de 1999. Durante três noites foram realizadas palestras sobre Nossa Senhora, dedicadas aos dogmas marianos - enfatizando o que era aceito ou não pela Igreja - e a última delas foi referente às aparições de Nossa Senhora. Nela o palestrante mencionou a cautela e a prudência recomendadas pelo Vaticano, bem como os critérios de avaliação, enfatizando a importância da adequação à doutrina católica e terminou demonstrando as características comuns entre os fenômenos reconhecidos.

Em apenas um momento as aparições de Jacareí foram mencionadas, justamente para lembrar a importância da prudência, recomendada para cada um dos participantes, e da adequação à doutrina. Para a grande maioria dos participantes do curso, que já conhecia as manifestações de Jacareí, ficou evidente no momento em que o palestrante começou a demonstrar as semelhanças entre as aparições de Nossa Senhora, as diferenças em relação às visões de Marcos.

Importa destacar que esta paróquia é um importante centro de referência para os carismáticos locais, sendo que o Pároco é um destacado membro da RCC na cidade e na região, sendo suas missas repletas de carismáticos de toda a cidade e mesmo de cidades vizinhas. Assim, o público das palestras foi constituído, em grande parte, por membros e lideranças da RCC na região. Ao final das palestras ficou clara a intenção dos organizadores - o bispo e o pároco - em alertar os paroquianos a respeito das aparições de Nossa Senhora, especialmente sobre as manifestações de Jacareí, que atraíam multidões devido, em grande parte, ao empenho de membros da RCC. O pároco de Jacareí teve uma postura mais explicita contra as aparições. Enquanto os paroquianos de São José dos Campos estavam sendo formados para o “discernimento”, ou seja, para que pudessem avaliar as aparições - embora com uma forte tendência a renegá-las - os fiéis de Jacareí foram proibidos de freqüentá-las, sendo ameaçados inclusive com a 
excomunhão. O pároco de Jacareí foi enfático quanto às “aberrações” das visões de Marcos, especialmente no que se refere às aparições de Santos - principalmente São José - fato que não está presente nas aparições reconhecidas.

O pároco de Jacareí usava argumentos que demonstravam a incompatibilidade entre as aparições de Marcos, a doutrina católica e as aparições reconhecidas, especialmente no que se refere aos “novos" elementos, como as visões de Santos e Anjos. Em suas palavras "isso nunca aconteceu antes, Maria aparecer tantas vezes, e ainda mais junto com Jesus e São José! Em Lourdes não foi assim, nem em Fátima. Tudo naquela aparição (a de Jacareí) demonstra a sua falsidade”.

Dessa forma, os elementos heterodoxos com relação às aparições reconhecidas eram usados para deslegitimar a aparição de Jacareí. Se em um primeiro momento houve a modelagem do fenômeno de acordo com o padrão estabelecido no século XIX para lhe atribuir legitimidade, nesta segunda década são justamente os elementos que demonstram o afastamento com relação ao padrão que são enfatizados pelos sacerdotes para demonstrar a sua falsidade. Isso foi realizado em São José dos Campos, por meio das palestras, e em Jacareí, pelas pregações do pároco ${ }^{62}$.

A inserção de novos elementos é percebida como heresia. Marcos quebra as regras do jogo, acrescentando elementos que não estavam presentes nas aparições reconhecidas. A sua ruptura com as aparições estabelecidas foi além do que era aceitável, demonstrando uma autonomia que impossibilitava a aceitação de suas visões como legítimas. Sua postura também contribui para o declínio das manifestações. As atitudes e falas de Marcos o afastaram do ideal de humildade e inocência constituintes dos videntes marianos, caracterizando-o, pelo contrário, como arrogante, adjetivo percebido na fala dos carismáticos e dos católicos locais em referência a ele.

\section{4) O Vidente e a Comunidade: da inconsistência ao isolamento}

No momento em que a diocese e a paróquia começam a “esclarecer” os participantes locais, realizando pregações e palestras contra as aparições de Jacareí, demonstrando a sua incoerência com a doutrina católica, o discurso da comunidade local, especialmente dos católicos, também segue na mesma linha. Ou seja, os

\footnotetext{
${ }^{62}$ Segundo o vidente, houve um combate generalizado a suas visões, realizado por vários padres da região e pelo bispo, que falavam contra elas em suas pregações. Não pudemos observar este fato em outras paróquias da região, apenas em Jacareí e em São José dos Campos, mas esta era uma fala recorrente de Marcos durante os Cenáculos, acusando "os padres" de pregarem "contra Nossa Senhora”. De qualquer forma, o combate a elas, por meio da desvinculação dos fenômenos reconhecidos foi a estratégia usada pelo clero local.
} 
moradores embasam sua descrença na incoerência com a doutrina católica, especialmente na diferença em relação às aparições reconhecidas de Nossa Senhora. O depoimento de Beth, católica praticante da paróquia de Jacareí ilustra bem este ponto:

"Nós começamos a perceber, a ver que aquilo que acontecia lá (no monte) nunca tinha acontecido antes. Não era nem parecido com as outras aparições de Nossa Senhora. Essa história de Jesus, de São José aparecerem, de falarem com o vidente nunca aconteceu! Então a gente foi percebendo que não era verdade, que nas aparições de Nossa Senhora não era assim.”

A inserção de elementos que fugiam do padrão das aparições reconhecidas causava incômodo nos paroquianos, levando-os a crer na falsidade das visões de Marcos Tadeu. Ou seja, a "novidade”, o fato disso "nunca ter acontecido antes” deslegitimava as aparições, pois as afastava do padrão recorrente.

Dessa forma, o vidente ganha autonomia, ele não é mais apenas o “mensageiro” da Virgem, mas também o intérprete das suas mensagens e o condutor do culto. Ele deixa de ser um instrumento vazio, por meio do qual Maria se manifesta, tornando-se um indivíduo.

Os novos papéis assumidos pelo vidente o afastam do padrão, em que os videntes são percebidos apenas como instrumentos de Maria. Lembramos aqui os casos de Bernadette - que seguiu fielmente as demandas da Instituição, tornando-se freira sendo constantemente vigiada e nunca falando com o público - e Lúcia, vidente de Fátima, que se tornou carmelita, vivendo reclusa. A partir do momento que o vidente deixa de ser um instrumento vazio, ganhando autonomia e falando por si, a percepção da veracidade de suas visões começa a se romper.

O processo de modelagem impedia a autonomia do vidente - no ritual e em sua personalidade. As “novidades" rituais não são bem recebidas porque demonstram a autonomia do vidente: acrescentando elementos e conduzindo o Cenáculo - afastando-o do modelo. Assim, os participantes começam a percebê-lo como arrogante, e não mais humilde - pois ele não reproduz o padrão de aceitação, mas toma atitudes, circula, interpreta mensagens; ou seja, torna-se um indivíduo, e não a reprodução de uma personalidade padrão.

Além disso, Marcos, ao tentar instituir a “novidade” em suas manifestações - em relação aos elementos simbólicos e rituais - acaba por romper abruptamente com 
as regras do jogo - em que a adequação ao padrão era central - instituindo novas regras que não são reconhecidas como autênticas pelos participantes. O “novo" não é percebido como verídico. Perde-se, então, a impressão de verdade que havia sido constituída durante a década de noventa através da adequação das aparições de Jacareí ao padrão. Dessa forma, a reciprocidade entre o vidente e os participantes é rompida.

A postura de Marcos também contribui para esse processo de deslegitimaçao das aparições. Além de professar constantemente sua exclusividade no contato com a Virgem e não aceitar "palpites” de ninguém, ele também não atende o público - os peregrinos devem enviar uma carta para marcar uma conversa, pois ele diz estar sempre muito ocupado com as "tarefas que Nossa Senhora lhe atribui". Além disso, refere-se constantemente, durante suas falas no Cenáculo, à preferência que Maria tem por ele, colocando-se como "um filho especial”.

Essas atitudes e falas do vidente criaram uma antipatia da comunidade local - inclusive dos católicos não praticantes - em relação a sua figura. A seguinte fala, proferida por ele durante um Cenáculo e atribuída à Virgem, é emblemática de sua postura: "Pelo meu filho Marcos e pelas obras que ele empreende em meu nome eu vos prometo salvar o Brasil”. Por essa e por falas de teor semelhante, Marcos confere valor e importância a si mesmo, por meio de palavras atribuídas a Nossa Senhora, passando a ser percebido como “aparecido”, “metido”, “arrogante” pelos católicos locais e pelos carismáticos.

Essas características contribuem para a sua deslegitimação enquanto vidente, pois elas são o oposto da humildade, da simplicidade esperada de um mensageiro de Nossa Senhora. Assim, quando os fiéis se deparam com frases como a anterior, em que o vidente faz questão de enfatizar a sua extraordinariedade, ou com o fato de não falar pessoalmente com os peregrinos, a construção da humildade e da simplicidade se desfaz, e eles se percebem diante de uma “celebridade”, que não fala com o público e que se considera extraordinário. O vidente, ele próprio, não permite a troca, considerando-se auto-suficiente.

Ou seja, a troca é rompida. A crença no dom do vidente era atribuída pelos participantes, que identificavam elementos que "provavam” a sua santidade. Entretanto, o vidente rompe com as regras do jogo, afastando-se destes elementos. A convicção na veracidade de suas visões é então quebrada.

Assim, as posturas do vidente, o acréscimo de elementos estranhos ao padrão de aparições marianas e a ruptura nas suas redes de relações sociais - afastando-o de 
membros importantes da rede de manifestações - levam à regressão dos Cenáculos, que são constituídos atualmente apenas por um pequeno grupo de participantes fixos.

A participação de pessoas da região é muito rara nos últimos anos, e as peregrinações de fora diminuíram significativamente, devido a sua dificuldade em mobilizar a rede de contatos sem a ajuda da RCC. Marcos, rompendo com os carismáticos, sendo combatido pelos sacerdotes e pela comunidade local, está cada vez mais isolado, e os seus rituais cada vez mais esvaziados.

Dessa maneira, na primeira década das manifestações o apoio da RCC e a modelagem das aparições de acordo com o padrão reconhecido foram centrais para o sucesso dos Cenáculos, já a partir dos anos 2000 a intransigência de Marcos, que se proclama “o” representante de Nossa Senhora, insinuando não precisar de mais ninguém, apenas “Dela”, e o seu afastamento do modelo reconhecido colaboram para que suas conexões se desfaçam e sua legitimidade seja questionada.

\section{5) A defesa e o ataque de Marcos}

Marcos não apenas insere novos elementos nas suas aparições, mas também inicia um processo de combate aos sacerdotes e ao bispo de São José dos Campos, realizado durante suas pregações nos Cenáculos e nas mensagens atribuídas a Nossa Senhora. Isso acontece como uma defesa do vidente após a rejeição de suas manifestações pelo clero local.

Em suas pregações durante os Cenáculos ele fala da existência de um combate generalizado dos padres contra as aparições, e, consequentemente, contra Nossa Senhora. Por isso ele avisa aos participantes que o clero está corrompido, pois não quer que as pessoas “venham ouvir as mensagens de nossa mãe celeste”. No entanto, segundo ele, apesar dos sacerdotes desaconselharem a participação nos Cenáculos, Maria pede enfaticamente que “seus filhos” compareçam e orem, que não ouçam os "maus conselhos" dos padres.

$\mathrm{O}$ ataque ao clero em alguns casos toma dimensões pessoais, e vem por meio de palavras atribuídas a Nossa Senhora. Uma mensagem que teve muita repercussão na diocese foi transmitida no Cenáculo de Novembro de 2005, em que, segundo o vidente, Maria diz que “o bispo Dom Nelson é o filho que ela menos ama”. Vale a pena analisar com mais cuidado este evento.

Ela foi proferida após o bispo ter se manifestado contra as aparições - para o vidente Marcos, em consulta particular, pois ele nunca as mencionou publicamente em 
suas pregações ${ }^{63}$ - fato que ofendeu o vidente. Segundo Marcos, ele foi "escolhido por Nossa Senhora”, ele é “o mensageiro de Maria”, assim, diante da rejeição do clero, do rompimento com a RCC, a única fonte de legitimidade que lhe resta é o contato com Maria, a crença em ser o único a receber as suas mensagens. Por isso Marcos usa as mensagens para combater a rejeição do clero. Entretanto, as mensagens de Maria não podem trazer elementos de discórdia, pois ela é a mãe carinhosa, que ama a todos os seus filhos - como analisaremos no próximo capítulo, a maternidade de Nossa Senhora é uma característica central das aparições - por isso não pode deixar de amar Dom Nelson. Porém, tudo indica que pode amar menos.

Marcos, em seu isolamento, apoiando-se em Nossa Senhora, em suas palavras e mensagens, acaba por criar uma escala de seu amor maternal, na qual ele é o mais amado dos filhos - por seguir as determinações de Maria -, em seguida vem aqueles que participam dos Cenáculos e também cumprem as determinações “dela”, e por último todas as pessoas que não participam, e principalmente aqueles que a combatem, inclusive o clero - os sacerdotes e o bispo, por não reconhecerem as aparições, e, pior, tentarem convencer os católicos a não participar das aparições.

Dessa forma, a única moeda que resta ao vidente é sua capacidade de falar com Maria. Ela, porém, não é suficiente, pois a construção da verdade da crença depende de uma reciprocidade de perspectivas, cuja troca ele rompe de maneira unilateral na forma como usa o seu dom.

\section{5) As aparições contemporâneas: continuidades e inovações}

Neste item nos propomos a analisar duas características centrais das aparições de Nossa Senhora em Jacareí: as mensagens transmitidas pela Virgem ao vidente e a presença do Rosário na imagem e nas mensagens de Maria, bem como nas práticas rituais dos Cenáculos. Notamos que estes elementos - as mensagens e o Rosário - estão presentes nas aparições de Nossa Senhora em Jacareí, mas também em outros fenômenos do mesmo tipo, sendo que os participantes os utilizam para estabelecer conexão e continuidade entre as aparições de Maria em diferentes épocas e em diferentes locais. Entretanto, estes dois elementos também ganham novas características nas aparições contemporâneas, ou seja, apesar de indicarem a

\footnotetext{
${ }^{63}$ Embora Dom Nélson não tenha se manifestado publicamente contra as aparições, ele nunca as apoiou e instruíu os sacerdotes de sua diocese a fazer o mesmo.
} 
continuidade entre esses fenômenos, estando presentes no padrão de aparições do século XIX, eles se ajustam as características do modo de vida contemporâneo, mas sem perder seus antigos significados. Isso fica mais evidente em relação ao Rosário, como demonstraremos a seguir.

\section{A) As mensagens e segredos}

A aparição e a transmissão da mensagem de Nossa Senhora para Marcos Tadeu é o momento central dos Cenáculos. Dado o período extenso das manifestações elas acontecem desde 1991 - há um grande número de mensagens atribuídas à Virgem de Jacareí. Por exemplo, em 2000 foi publicado um livro com as mensagens transmitidas até aquele ano, que possui 860 páginas. Atualmente são editados CDs anuais com as mensagens de cada visão.

A transmissão de mensagens é um dos aspectos inovadores das aparições do Século XIX, sendo elas as responsáveis pela dimensão pública das manifestações da Virgem a partir deste período. Anteriormente, como demonstrado por Barnay (2000), o contato de Maria com os homens já existia, porém, não havia a transmissão de uma mensagem destinada a toda a humanidade, que deveria atingir um grande número de pessoas, de realizar a conversão. Esta dimensão proselitista do contato de Maria com os homens é estabelecida no século XIX, a partir das três aparições francesas mencionadas no início deste capítulo - Rue du Bac, La Salette e Lourdes - e devido à intervenção da Igreja sobre elas, como demonstrado anteriormente.

Além da dimensão pública das mensagens, também o conteúdo delas possui elementos semelhantes desde este período. Segundo Carlos Steil o modelo das aparições marianas é estruturado a partir Fátima, e também de La Salette ${ }^{64}$, destacando o papel importante das mensagens e segredos transmitidos por Nossa Senhora. Segundo este autor “A mensagem, geralmente relacionada ao contexto em que vivem os devotos, e os segredos, que apontam para o fim dos tempos e para a afirmação da autoridade da Igreja, se tornam o eixo em torno do qual o evento e o discurso das aparições modernas vão se organizar” (2003:29).

\footnotetext{
${ }^{64}$ La Salette foi uma aparição ocorrida na França, no final do século XIX, a duas crianças - Mélanie e Maximin, em que ocorreram a transmissão de mensagens e segredos, em um padrão semelhante à Fátima. Porém, essa aparição não se tornou conhecida como Fátima, não sendo um grande santuário de peregrinação na atualidade. Mais adiante nos deteremos nos fatores que colaboraram para a imensa divulgação de Fátima no Brasil. Interessa lembrar que Fátima era chamada pela imprensa portuguesa da época de "La Salette portuguesa", tamanha a semelhança entre estas duas manifestações, especialmente no que se refere às mensagens de cunho escatológico. Inclusive, durante o inquérito, foi perguntado se as crianças videntes tinham conhecimento da história acontecida na França, na busca de alguma influência.
} 
A partir de então, o recado da Virgem para a humanidade, ou seja, as mensagens são centrais neste tipo de fenômeno, quase não existindo manifestações em que a crença no contato verbal de Nossa Senhora esteja ausente. Dessa forma, o vidente é um intermediário entre o mundo humano e o mundo divino. Ele é capaz de ver e ouvir as mensagens de Maria, sendo também responsável pela sua divulgação, pois elas têm um caráter público, sendo destinadas para todos os homens.

Em Jacareí, Marcos é considerado um intermediário, um “escolhido pela Virgem”, que tem como obrigação divulgar as mensagens que Maria lhe transmite, destinadas à toda a humanidade. Por isso a construção do Santuário e a realização dos Cenáculos, bem como a impressão de livros e CDs: as palavras de Nossa Senhora devem atingir o maior número possível de pessoas.

A diferença entre esse modelo de aparições estabelecida no século XIX e a aparição de Jacareí refere-se ao número de mensagens. Em La Salette foram três mensagens, uma a cada aparição, em Lourdes foram oito mensagens nas dezoito aparições, e em Fátima sete mensagens em sete aparições. Já em Jacareí o número de aparições é imenso, sendo cada uma delas acompanhada da transmissão de uma mensagem. Desta forma, mesmo se levarmos em conta apenas as mensagens especiais, transmitidas mensalmente, elas ainda são numericamente muito superiores às mensagens atribuídas a Nossa Senhora em Lourdes, Fátima e La Salette.

O grande número de mensagens as torna banais, especialmente as diárias. Os peregrinos não se mostram muito interessados nelas, pois, devido a sua proliferação, elas se tornaram repetitivas, sem nenhuma grande novidade. Por isso o grupo de apoio e o vidente criam mecanismos para tornar algumas mensagens "especiais”. Dois deles podem ser mencionados: as mensagens mensais ocorridas durante o Cenáculo e as mensagens de aniversário das manifestações. Entretanto, mesmo essas mensagens consideradas “especiais” não possuem nada de inovador em relação aos elementos e temas presentes a quinze anos atrás ${ }^{65}$.

Autores que estudaram aparições contemporâneas já haviam atentado para o fato de que o número de mensagens e de aparições nos fenômenos atuais é muito superior ao das aparições modernas, como Tânia Almeida (2004) - sobre a aparição de Piedade das Gerais. Nesse sentido, ela destaca a formação de um novo padrão de

\footnotetext{
${ }^{65}$ Analisaremos os elementos das mensagens no capítulo seguinte, referente à continuidade simbólica das manifestações.
} 
aparições do qual a aparição de Medjugorje é considerado o modelo, em que o grande número de aparições com transmissão de mensagens prevalece.

A aparição de Jacareí segue esse novo padrão no que se refere ao número de manifestações, entretanto, não podemos deixar de destacar que a presença de elementos semelhantes aos das aparições reconhecidas ainda é muito importante. Ou seja, apesar das aparições contemporâneas apresentarem novas características, a sua adequação às aparições reconhecidas permanece central.

No caso de Jacareí, Maria se comunica com o vidente desde a primeira aparição, mas, a princípio é apenas uma conversa, sem a transmissão de mensagens para a humanidade, que começam a ocorrer apenas dois anos depois, quando a figura se identifica como Nossa Senhora. Então, de forma semelhante ao ocorrido com a história das aparições, as mensagens somente tornam-se públicas em um momento posterior, quando os carismáticos já se apropriaram do fenômeno, indicando novamente a modelagem das aparições de Jacareí ao padrão das aparições modernas, neste caso por meio da atribuição de um caráter proselitista às comunicações de Maria - as mensagens.

Além das mensagens, outro elemento surgido no século XIX são os chamados segredos. Eles também estabelecem a comunicação entre Nossa Senhora e os videntes, mas, ao contrário das mensagens, que devem ser divulgadas para todos os homens, os segredos devem ser mantidos pelo vidente.

Assim, o vidente divulga que a Virgem realizou uma profecia, mas não relata seu conteúdo, pelo contrário, a envolve numa aura de grande mistério, enfatizando a importância deste segredo - que também destaca a sua própria importância como único conhecedor de algo revelado por Nossa Senhora.

A aparição que bem exemplifica a centralidade dos segredos nas aparições modernas, assim como o grande mistério que os envolvem, é a aparição de Fátima, em que, segundo os relatos, a Virgem transmitiu três segredos para os videntes, na forma de profecias. Os videntes apenas poderiam revelar estes segredos após a sua concretização - devendo compartilhá-los apenas com o Papa. Houve muita especulação a respeito deles, especialmente sobre a sua dimensão escatológica, havendo a constante associação entre os segredos e previsões sobre a proximidade do juízo final, destacando os castigos e características dos tempos finais. Acreditava-se que Nossa Senhora havia demonstrado detalhes dos acontecimentos que precederiam o fim dos tempos que não poderiam ser revelados para os homens. 
Este padrão se repete em Jacareí,onde, segundo os relatos, Nossa Senhora fez oito revelações secretas para Marcos Tadeu, que envolvem os castigos do final dos tempos e visões do inferno. Segundo ele, os segredos são assustadores, e, como em Fátima, enfatizam a escatologia ${ }^{66}$. Não nos deteremos no conteúdo das mensagens e segredos neste momento, mas na forma semelhante como Marcos age diante deles, destacando sua dimensão terrível e escatológica, mas sem relatar seu conteúdo, envolvendo-os em mistério e incitando as especulações a seu respeito, exatamente como em Fátima e também em Garabandal, duas aparições que são referência para a dimensão profética destes fenômenos.

Para explicar a participação dos peregrinos devemos nos deter no conteúdo das mensagens e segredos, que embora não sejam novos, ganham sentidos importantes e relacionados com o agir religioso no mundo contemporâneo.

\section{2)O Rosário e Nossa Senhora}

A importância do Rosário é uma característica marcante das aparições de Jacareí. Ele está presente durante o Cenáculo, em que o Rosário e outros terços são rezados - como o terço da libertação, de Nossa Senhora desatadora dos nós, entre outros. Nas mensagens atribuídas a Maria, bem como nos relatos dos peregrinos. Além disso, a imagem de Nossa Senhora de Jacareí possui um Rosário nas mãos, sendo que o vidente afirma que a Virgem lhe aparece sempre o segurando. Assim, em dimensões centrais dessa aparição o Rosário assume um lugar central - nas representações, nas mensagens, nas práticas durante os Cenáculos e na fala dos devotos.

O terço é mais um elemento que aponta para a continuidade simbólica destes fenômenos. Um exemplo disso é a importância do Rosário na visão de Fátima lembramos que na visão portuguesa a Virgem se autodenominou a "Senhora do Rosário” e a sua representação, elaborada a partir dos relatos da vidente Lúcia, a apresentam com um terço branco nas mãos ${ }^{67}$. Além disso, também nas mensagens aos videntes de Fátima há o pedido de Maria para que as pessoas o orem cada vez mais.

\footnotetext{
${ }^{66}$ Os segredos somente começaram a aparecer como elemento ritual depois do contato de Marcos com outros videntes e de suas peregrinações pos Santuários Marianos.

${ }^{67}$ É esta a representação presente, por exemplo, na capa do livro que contém as mensagens transmitidas por Nossa Senhora de Fátima ao confidente Pe Gobbi. É esta também a representação da Virgem que circula pelo Brasil vertendo sangue pelos olhos.
} 
Desde então, o Rosário é um elemento que se repete com extrema freqüência em várias aparições, sendo um dos elementos que estabelecem conexão entre as manifestações marianas. A seguinte passagem, presente no Portal Anjo, mostra que a oração do Rosário é recomendada por Maria em suas manifestações, ilustrando essa conexão: "Desde Fátima até os dias atuais em Medjugorje, a Virgem Imaculada nos adverte do peso dos nossos pecados e nos exorta a oração do Rosário”. Essa passagem, além de nos lembrar o papel inaugural atribuído a Fátima pelos devotos, estabelece uma linha de continuidade entre essas manifestações, em que o Rosário é um dos elementos que as conectam ${ }^{68}$.

A relação entre o Rosário e Maria é bastante antiga no catolicismo. Segundo Marina Warner, a sua disseminação se deu a partir do século XIII, quando, segundo a tradição, um Rosário foi dado para Santo Domingo pela Virgem, durante uma aparição. Nesse sentido, não apenas as orações majoritárias rezadas no Rosário são dirigidas a Nossa Senhora - as Ave Marias - como o próprio surgimento dessa forma de orar é atribuído a um evento sagrado, em que Nossa Senhora aparece a um vidente.

Essa imagem ganhou força, sendo amplamente divulgada entre os devotos do Rosário. É atribuído a ele, pois, um caráter sagrado devido, em parte, a sua origem em um episódio extraordinário, em uma visão. Segundo Warner, é a partir de então que o Rosário se dissemina com maior força no catolicismo, sendo os franciscanos e os dominicanos os responsáveis por sua extensão aos leigos e aos analfabetos, como uma substituição às orações mais sofisticadas. Assim, desde seus primórdios, o Rosário está associado à figura de Maria e, além disso, ao fenômeno de contato do divino com o humano, sendo ele próprio divino, pois dado pelas mãos de Maria a um sacerdote.

Nesse sentido, o Rosário faz parte não apenas da iconografia das Virgens relacionadas às aparições, mas é uma prática muito comum entre os devotos de Nossa Senhora. Em todas as manifestações que presenciamos, e não apenas em Jacareí, a oração do terço ou do Rosário era parte do ritual. Em Jacareí a oração do Rosário começa por volta das dez horas da manhã, sendo intercalado por mensagens e cânticos, e se estende até por volta do meio dia, quando ocorre o ápice do ritual, a aparição de Maria ao vidente Marcos. Os encontros do MSM, para a leitura e comentários sobre o livro de mensagens recebidas pelo confidente Pe Gobbi é sempre precedido pela reza de

${ }^{68}$ As referências ao Rosário se repetem nas manifestações analisadas - Itaperuna, Vinhedo, Belo Horizonte, Jacareí, Anguera, Piedade das Gerais, Taquaras - e também em sites que mencionam fenômenos desse tipo - Portal Anjo, Deus fala Conosco, Cruz Gloriosa - e que destacam a importância da oração freqüente do Rosário. 
um terço. Quando a Virgem do mel visitou a comunidade Magnificat, houve, ao longo do dia, vários momentos em que foi rezado o terço. Em Vinhedo, a oração do Rosário faz parte do ritual dos cenáculos comemorativos das aparições. Em São José dos Campos, na capela de Nossa Senhora de Fátima, todos os dias treze - dia em que Maria aparecia aos pastorzinhos em Portugal -, às seis horas da tarde - hora da Ave Maria - há a reza de um terço, que precede uma pequena procissão, acompanhando o andor de Nossa Senhora de Fátima, embalada por cânticos marianos. Poderíamos citar uma série de outros exemplos de rituais marianos em que a reza do terço está presente.

A devoção a Nossa Senhora e o Rosário estão, pois, profundamente imbricados há séculos, sendo que a quase impossível tratar de um sem mencionar o outro. Pelikan (1996) e Warner afirmam, inclusive, que a disseminação e popularização da devoção a Nossa Senhora ocorreu devido à disseminação do Rosário. Segundo Pelikan, a figura de Maria esteve apenas superficialmente presente nas liturgias oficiais, sendo que a devoção a ela se expande e se populariza, em grande parte, devido a duas exortações - que se tornam universais no catolicismo romano - surgidas, respectivamente, entre os dominicanos e os franciscanos: o Rosário e o Ângelus ${ }^{69}$. O Rosário e Nossa Senhora caminham juntos há séculos.

A relação entre o Rosário, Nossa Senhora e a guerra também advém deste período, permanecendo presente nas aparições contemporâneas. Em seu livro “Alone of all her sex” Warner (1983) dedica um capítulo a esse tema, denominado “Apariciones, el rosário y la guerra”, em que estabelece as relações entre eles ${ }^{70}$. Voltaremos a este tema a seguir.

Repondo a relação entre Maria e o Rosário, o fato dela aparecer com o Rosário é também significativa, pois a Senhora do Rosário é uma denominação Mariana muito antiga e importante, tanto em solo brasileiro como português, sendo a denominação de devoção de várias irmandades do catolicismo popular. Há duas simbologias que devem ser consideradas quando nos referimos a Nossa Senhora do

\footnotetext{
${ }^{69} \mathrm{O}$ Ângelus, também chamado popularmente de Ave Maria, é, justamente, o costume de se badalar os sinos diariamente, às seis horas da tarde, em chamamento para a oração da Ave Maria. Esse costume ainda é muito arraigado nas pequenas cidades brasileiras, em que o horário das seis horas é conhecido como a hora da Ave Maria.

${ }^{70}$ A guerra analisada por ela pode ser tanto guerras de fato, como as cruzadas, ou a batalha espiritual contra o inimigo - esse tema se estende para as aparições do século XX e da atualidade, sendo a guerra entre Maria e o inimigo um elemento recorrente nesses fenômenos, que será analisado posteriormente. Importa lembrar que, na batalha destacada atualmente pelos devotos, os significados atribuídos aos símbolos mudaram, sendo o "inimigo" considerado o demônio e a principal arma dos homens a oração, especialmente do Rosário. A batalha permanece com os mesmos elementos, porém, se desenrola, de acordo com os devotos, no plano espiritual.
} 
Rosário: o fato dela ser a denominação Mariana guerreira por excelência e o fato dela ser a Virgem de devoção das camadas mais empobrecidas, especialmente aos negros escravos ou libertos - tanto no Brasil como em Portugal ${ }^{71}$.

As características guerreiras são associadas especialmente a Nossa Senhora do Rosário, como demonstrado por Marina Warner. No Brasil, mesmo antes dela tornarse a santa de devoção dos negros e escravos libertos, a devoção a ela já estava presente. Segundo Hoornaert (1974), imediatamente após a chegada dos portugueses ao país, a devoção estabelecida - imagens e capelas - foram referentes à gratidão, por terem conseguido atravessar os perigos do mar e pela admiração as belezas da nova terra como Nossa Senhora da Graça, Nossa Senhora da Esperança e Nossa Senhora das Maravilhas. Entretanto, logo surgiram as imagens guerreiras - sendo que a segunda Igreja de Salvador foi dedicada a Nossa Senhora da Vitória, e seguidas de muitas outras - sempre se referindo as vitórias dos cristãos contra os indígenas e, posteriormente, contra os holandeses. Nesse sentido, o autor destaca o caráter guerreiro da devoção a Nossa Senhora no Brasil, sendo o Rosário considerado a arma da Maria contra os inimigos.

A característica guerreira de Nossa Senhora é muito presente nas aparições, sendo que na maioria delas Nossa Senhora é concebida como a combatente, como líder de um exército na batalha contra o inimigo - Satanás. Isso explica suas aparições: elas destinam-se a avisar os homens da necessidade de se combater o pecado, de arregimentar mais guerreiros para a sua batalha, cuja principal arma é o Rosário. Apenas através da oração do Rosário a humanidade poderá combater o mal, por isso ela recomenda cada vez mais a "sua" oração - a forma mais eficiente de se "combater o inimigo"72.Assim, como no Brasil colonial e a outros momentos em que essa simbologia foi acionada, o Rosário aparece como a arma de Maria contra o inimigo que varia de acordo com a situação, e emerge na metáfora do pecado.

Nesse sentido, a simbologia guerreira de Nossa Senhora é importante no catolicismo e recorrente nas as aparições, sendo uma característica arraigada no catolicismo popular e também enfatizada nas aparições. Assim, notamos que sua força depende também de sua continuidade em relação, por um lado, ao catolicismo popular

\footnotetext{
${ }^{71}$ As irmandades e a devoção a Nossa Senhora do Rosário foram muito comuns desde o Brasil colonial, estando sempre associada às camadas menos favorecidas da população, especialmente aos negros escravos ou libertos

${ }^{72}$ Essa é uma expressão muito recorrente entre os participantes das aparições: o combate de Nossa Senhora ao inimigo.
} 
e, por outro lado, com as aparições reconhecidas, no caso Fátima. O Rosário estabelece uma conexão entre elas que enfatiza a existência de um combate liderado por Nossa Senhora, a mãe guerreira - simbologia que analisaremos com cuidado posteriormente.

O Rosário foi a prática de oração mais comum nesta religiosidade, mas a proximidade entre as aparições de Nossa Senhora e o catolicismo popular não se restringe a ela. Ao longo de nosso trabalho notamos a presença de várias práticas reconhecidas pelos estudiosos do tema como típicas e comuns do catolicismo popular.

Estudos importantes sobre o tema, como o desenvolvido por Ribeiro, que analisa a religiosidade popular a partir de suas “constelações práticas” -, destaca as devoções aos santos e suas festas, a reza do terço, as procissões e as romarias como centrais nesta religiosidade. Já Azzi, outro especialista da religiosidade popular, considera fundamentalmente dois aspectos: a devoção aos santos e seus ritos e as orações e rezas conduzidas pelos leigos, sem a presença de sacerdotes. Assim, elementos importantes observados nos fenômenos de nosso estudo são característicos do catolicismo popular: a centralidade das peregrinações nas aparições contemporâneas já foi analisada no capítulo anterior, a proximidade com os Santos e a reza do terço não podem ser ignoradas nestas manifestações.

No que se refere à devoção aos santos, é interessante notar, por um lado, seu aspecto festivo, e, por outro lado, a proximidade estabelecida entre o devoto e "seu" santo, sendo tratado como alguém da família "são de casa, tratados com aquele à vontade com que se tratam as pessoas da família. Até ironias e debiques cordiais os santos recebem. E revidam, é claro, pois isso é comum entre amigos, ou melhor, entre compadres." (Faustino;1996:40) Esse aspecto de proximidade e intimidade com os santos é perceptível nas aparições de Maria, e serão analisados com mais detalhes posteriormente.

Também as rezas são constitutivas das manifestações extraordinárias de Maria no Brasil. Segundo esses autores, a principal reza realizada na religiosidade popular é o Rosário ou terço de Nossa Senhora, tirado por algum rezador diante dos pequenos oratórios familiares ou em pequenas capelas rurais. Essa é uma prática ritual marcante do catolicismo popular brasileiro desde séculos, e que permanece comum não apenas nas localidades rurais e distantes, mas também nos grandes centros urbanos. Dessa maneira, as reuniões de pessoas em torno de uma liderança leiga para se rezar o terço é uma prática ritual muito antiga e difundida no catolicismo brasileiro e que se repete nas manifestações de Nossa Senhora. Assim, a reza do terço é mais um elemento 
que aproxima os Cenáculos das práticas rituais do catolicismo popular, como a realização de peregrinações, a presença do cruzeiro e o pagamento de promessas.

Entretanto, de maneira semelhante às peregrinações, os terços também ganham novas características na atualidade. A oração do Rosário, embora enfatizada pela Virgem em suas aparições e presente nos Cenáculos, não faz parte da rotina dos peregrinos. Em seu dia a dia eles se atêm aos "novos” terços, como o terço da libertação e/ou de Nossa Senhora Desatadora dos Nós ${ }^{73}$, que possuem a mesma estrutura do terço tradicional, mas que, em vez das ave-marias e pais-nosso, usa jaculatórias bem menores, que possibilitam a sua oração em cerca de dez minutos. Estas orações são rezadas durante a circulação das imagens peregrinas, por exemplo.

Dessa forma, a relação entre Maria e o Rosário permanece presente nas aparições contemporâneas, mas passa por pequenas releituras, que as inserem no modo de vida característico das populações urbanas da atualidade. Os “novos terços” são exemplos disso, eles são orações muito rápidas - diferentes do Rosário tradicional, que demora mais de uma hora para ser rezado - e simples, possibilitando a sua reza diária em um contexto contemporâneo em que a "falta de tempo" caracteriza o modo de vida das pessoas. Nesse sentido, vários participantes das aparições afirmam realizar diariamente a reza de pelo menos um destes terços, destacando a sua facilidade e a possibilidade de realizá-la a qualquer momento do dia, como a caminho do trabalho, no ônibus, no trânsito e no intervalo do almoço. Ou seja, é “a oração perfeita para a vida moderna”, como poderia dizer qualquer revista de comportamento sobre uma dieta ou uma atividade física que "promete” a obtenção do objetivo em apenas quinze minutos de esforço diário. Os novos terços podem ser considerados um tipo de “oração express”, sendo realizados em qualquer pequeno espaço de tempo livre e rapidamente, mas atingindo o resultado desejado.

Além disso, os novos terços são uma forma de oração individual. Embora existam grupos que se reúnam para a sua oração, como a circulação das imagens peregrinas, eles são principalmente rezados individualmente nos intervalos de tempo dos fiéis. Assim, eles possibilitam, por um lado, a associação dos fiéis em grupos de parentesco e vizinhança que se reúnem para a sua oração - discutida no primeiro capítulo - e por outro lado, atendem a uma demanda dos indivíduos na atualidade: o dispêndio de pouco tempo para a obtenção dos resultados desejados.

\footnotetext{
${ }^{73}$ Estas orações são muito divulgadas pela RCC, inclusive por sua rede de televisão, a Canção Nova.
} 
Já durante o Cenáculo a principal oração é o Rosário tradicional. No entanto, esse momento é percebido como tempo livre pelos participantes - eles permanecem o domingo todo no Santuário: conversam, passeiam, comem, e também rezam. Durante toda a manhã de domingo são realizadas orações, e o Rosário não pode faltar. Esse dia é percebido como momento de lazer pelos peregrinos, a peregrinação é mais uma diversão do que uma obrigação para eles - esse tema será aprofundado em capítulo posterior -, sendo que a sua percepção do tempo também muda: eles estão ali para "gastar” o tempo, portanto, a longa duração do Rosário não é um problema, pelo contrário, além de atender a um pedido da Virgem, ela preenche o tempo livre.

A presença do terço, a sua associação com a figura de Maria e com toda uma simbologia associada a ela demonstram a importância do imaginário de longa duração na formação e construção de legitimidade destes fenômenos. Ainda assim a inovação está presente, possibilitando a permanência destes fenômenos na religiosidade contemporânea.

As peregrinações para os Cenáculos e a oração do Rosário são dois exemplos de práticas rituais muito antigas no catolicismo e características da religiosidade popular que permanecem como elementos centrais nas aparições marianas contemporâneas. Ambas, porém, passam por alterações que as tornam compatíveis com o modo de vida das sociedades atuais e com o agir religioso contemporâneo. 


\title{
QUARTO CAPÍTULO
}

\author{
MARIA NAS APARIÇÕES \\ ELEMENTOS SIMBÓLICOS E MENSAGENS
}

\author{
"A alegria com a qual sucessivas \\ gerações lhe atribuíram o título de santa \\ variou muito através dos séculos, porém, em \\ todas as épocas foram notáveis o êxito e a \\ importância alcançados pela bem-aventurança \\ de Maria, tanto entre os homens como entre as \\ mulheres, nas mais variadas situações. E, na \\ verdade, isso realmente faz dela uma Mulher \\ para Todas as Épocas.” \\ Jaroslav Pelikan
}

Nesse capítulo discutiremos as características assumidas por Nossa Senhora nas aparições marianas, demonstrando a riqueza simbólica desta figura e sua importância no catolicismo. Maria é a Santa que possui o maior número de denominações, sendo que as suas características variam de acordo com elas, bem como de acordo com a configuração em que se encontra inserida.

Além disso, as características e papéis de Nossa Senhora são constituídos ao longo do tempo, sendo que as suas características apreendidas nas aparições reportamse, em muitos casos, a papéis assumidos em momentos anteriores e/ou em outros contextos. Neste capítulo procuramos identificar as características atribuídas a Nossa Senhora em suas aparições, demonstrando, por um lado, a sua profundidade histórica e, por outro lado, o sentido que lhes é atribuído nas manifestações da atualidade.

Assim, demonstramos que os símbolos marianos presentes nas aparições não são novidades estabelecidas por estes fenômenos, mas, pelo contrário, fazem parte de um imaginário cristão/católico de longa duração. 
A multiplicidade de papéis e características associados a Nossa Senhora também foi observada nestes fenômenos. Historiadores da mariologia já se detiveram sobre a multiplicidade de Maria. Segundo Jaroslav Pelikan (2000), ela, através dos séculos, assume diferentes papéis na história da cultura. Também Marina Warner (1983), em seu livro “Alone of all her sex” concentra-se nos diferentes aspectos da Virgem em diferentes momentos.

Sabemos, pois, que Nossa Senhora possui uma grande variedade de características, bem como assume diferentes papéis, não apenas ao longo da história do catolicismo, mas também nas suas diversas denominações e no contexto em que estão inseridas. Ou seja, Maria, apesar de única, é também múltipla, possuindo numerosas representações no catolicismo. Citando Almeida (2003) “Moldada e animada em diversos contextos históricos e sociais, Maria tem assumido diferentes aspectos, propiciando o surgimento de inúmeras devoções marcadamente distintas” (2003:69). Ao analisarmos a simbologia da Virgem em Jacareí, pois, estamos nos voltando para características que foram sendo atribuídas a Maria através de séculos de cristianismo, pela ortodoxia católica e/ ou pela tradição popular, em suas diversas denominações e devoções.

Reportamo-nos neste ponto ao estudo realizado por Almeida sobre as aparições da Virgem em Piedade das Gerais, no interior de Minas, em que analisou o pertencimento deste símbolo católico a três esferas: a cultura bíblica, a cultura eclesiástica e a cultura popular, considerando "que sempre houve entre os conjuntos discursivos um relacionamento circular feito de influências recíprocas, que se move de um lado para o outro, de cima para baixo e vice versa.” (2004:69).

Dessa maneira, a autora demonstra como na aparição da Virgem em Piedade das Gerais estão presentes elementos associados à Maria na Bíblia, nos dogmas eclesiásticos e na tradição popular. Ou seja, cada uma destas três esferas contribui para a constituição da representação da Virgem de Piedade, demonstrando a circularidade e a convivência entre elas. Assim, a autora localiza as características de Nossa Senhora em cada uma destas três esferas, destacando que elas estão em constante diálogo, estão conectadas, podendo haver referências a um mesmo símbolo em cada uma delas, embora a interpretação dada a ele possa variar. Exemplo disso é a maternidade divina de Maria. Há referências na bíblia sobre esse tema - cultura bíblica -, mas trata-se também de um dogma mariano - cultura eclesiástica -, além de ser uma crença amplamente presente no catolicismo popular - cultura popular. Embora não seja nosso intuito 
abordarmos as aparições como pertencentes a um “grupo ou tradição cultural”, o estudo realizado pela autora é interessante, pois demonstra a amplitude e a diversidade da simbologia mariana, pois ela pertence, de maneira peculiar e simultânea, a todas as três esferas.

Assim, analisamos as características e papéis atribuídos a Nossa Senhora nas aparições contemporâneas tendo por base a aparição de Jacareí. Nesse sentido, observamos a atribuição de valor e responsabilidade aos indivíduos a partir desta simbologia, percebida no discurso dos participantes - peregrinos e videntes. Atrelada às características e papéis de Maria nas aparições constatamos, pois, uma concepção de indivíduo moderno, que se mostra central para os devotos. Analisaremos estas concepções ao longo deste capítulo.

Antes disso, iniciamos o capítulo analisando o lugar ocupado por Nossa Senhora na doutrina católica - os dogmas marianos oficialmente estabelecidos pela Igreja - pois, além da importância do papel desempenhado pela instituição nestas manifestações, duas características centrais de Maria nas aparições estão relacionadas aos dogmas - a maternidade e a mediação.

\section{1) Os dogmas marianos}

O catolicismo oficial considera quatro dogmas relacionados à Virgem Maria: Maternidade Divina, Virgindade, Imaculada Conceição e Assunção. Eles foram estabelecidos em datas históricas diferentes pelo Vaticano. Os dois primeiros dogmas possuem fundamento bíblico, já os outros dois - Imaculada Conceição e Assunção foram incorporações de antigas tradições populares pela Instituição (Warner, 1983).

O primeiro dogma mariano - a Maternidade Divina - foi proclamado no século V. Segundo Warner (1983) é o único citado nos Evangelhos, Maria é vista como a mãe de Jesus em algumas passagens, como nas bodas de Caná e na Crucificação de Cristo. Inclusive, Maria é uma figura quase ausente no novo testamento, sendo mencionada em poucas passagens, sendo que, segundo Pelikan (1996), foi durante os primeiros séculos do cristianismo que a sua figura foi ganhando centralidade, e a devoção a ela construída. Nesse sentido, os dois primeiros dogmas - a maternidade divina e a virgindade - foram estabelecidos neste período, e dois últimos apenas muitos séculos depois, já no século XIX, quando Maria é novamente colocada no centro da cena do catolicismo. 
Assim, a crença de que Maria é a mãe de Deus remonta aos primeiros séculos do catolicismo, sendo muito recorrente nas aparições marianas e parte importante da explicação para estas manifestações, segundo os devotos. Para eles, Maria aparece por que é mãe, em suas palavras "Maria se manifesta porque está preocupada com seus filhos". Como o dogma da maternidade divina estende-se para toda a humanidade - Maria não é apenas mãe de Cristo, ela é considerada a mãe da cada pessoa - ele serve de explicação para as aparições. Maria assume a figura de "mãe preocupada", aquela que vem avisar seus filhos, que vem checar seu comportamento. A importância da concepção de Maria como “mãe da humanidade” nas aparições será analisada a seguir, devemos reter neste ponto que a maternidade de Maria é um dogma católico, o mais antigo da religião, central e amplamente divulgado entre seus fiéis, e que é parte importante da explicação sobre as aparições marianas na atualidade.

O segundo dogma - a Virgindade de Maria - foi proclamado um pouco mais tarde. Esse dogma possui base nas escrituras, apesar de não ser citado nos Evangelhos. O catolicismo considera a virgindade de Maria não apenas anterior à concepção de Jesus como durante e após o parto, havendo a manutenção eterna de sua virgindade. Esse dogma não é citado durante as aparições, apesar dos fiéis eventualmente se referirem a Nossa Senhora como "Virgem", esse dogma não é referido nas manifestações analisadas.

Os dois últimos dogmas, a Imaculada Conceição e a Assunção, foram incorporações de tradições populares realizadas pela Igreja e ocorridas, respectivamente, no final do Século XIX e no Século XX (1950). Segundo o dogma da Imaculada Conceição, Maria foi concebida sem pecado, ou seja, estava livre do pecado original porque sua mãe, Santa Ana, a concebeu devido a um milagre de Deus, sem manter relação sexual com seu marido, São Joaquim. Como mencionamos, este terceiro dogma foi proclamado muitos séculos após o segundo, no momento em que a Igreja utiliza-se das tradições populares para se manter em uma sociedade européia que se torna cada vez mais laica. Sob esse aspecto, o dogma da Imaculada Conceição é a incorporação de uma antiga crença popular em um momento em que a Igreja necessitava se auto-afirmar, sendo que as aparições do século XIX colaboraram para este seu objetivo, especialmente Lourdes. Em Lourdes a aparição afirma "Eu sou a Imaculada Conceição” alguns anos após a proclamação deste dogma, em Jacareí está presente exatamente a mesma frase em algumas mensagens atribuídas a Maria. Há 
relação, pois, entre a proclamação deste terceiro dogma e a centralidade dada pela Igreja as aparições marianas no século XIX, da qual a aparição em Lourdes é exemplo.

Entretanto, nas aparições contemporâneas, como em Jacareí, a repetição desta frase atribuída a Nossa Senhora soa como uma mera reprodução de uma fala mais antiga e legítima de Maria - talvez uma das mais conhecidas de suas falas, pois está gravada na imagem da Virgem na grota de Lourdes, o Santuário Mariano mais visitado do mundo - pois não é comentada pelo vidente e nem mencionada pelos peregrinos, não possuindo centralidade nos fenômenos atuais. Sob esse aspecto, a presença desta frase em algumas mensagens atribuídas a Maria em Jacareí é mais uma demonstração da circulação de símbolos nas manifestações deste tipo, neste caso principalmente devido ao vidente Marcos Tadeu e a alguns integrantes do grupo de apoio, que conhecem os relatos e mensagens de outras manifestações, bem como já peregrinaram para os principais Santuários Marianos de aparição.

O quarto dogma é a Assunção, reconhecido pelo Vaticano apenas no século XX, que concebe que Maria subiu aos céus após a sua morte, ou seja, ressuscitou. Não é admitida a idéia, comum em algumas tradições - como o catolicismo popular latino americano - de que Maria foi levada aos céus de corpo e alma, ou seja, não morreu. No caso das aparições, especificamente da aparição de Jacareí, o dogma da assunção não é mencionado diretamente, porém, existem referências à presença física de Maria durante as manifestações. Segundo Marcos Tadeu, Nossa Senhora aparece "em seu corpo divino”, fisicamente, ele pode tocá-la, abraçá-la, sentir o seu odor. A idéia de que Maria possui um corpo físico remete a tradição popular, à concepção de que Maria subiu aos céus de corpo e alma, assim como Jesus. O aspecto humano, carnal de Nossa Senhora é enfatizado, ela aparece como pertencendo ao mesmo gênero que os participantes, com corpo e cheiro - o odor de Maria é constantemente referido. Assim, os devotos a reconhecem como uma semelhante humana, como mulher - uma humana especial, que pertence também ao mundo divino, mas que permanece sendo humana e por isso mediadora - outra característica importante de Maria nas aparições.

Nesse sentido, dois dogmas marianos são centrais na construção simbólica de Maria nas aparições: a maternidade divina e a assunção - embora em termos de uma releitura tradicional popular deste dogma. Maria é mãe dos homens e também humana, embora pertencente ao plano divino, sendo, pois, a mediadora. A centralidade destas duas características de Nossa Senhora nas aparições será aprofundada a seguir. 


\section{2) Maria: quem é esta mulher?}

Ao longo de nossa pesquisa sobre as aparições de Jacareí duas dimensões de Nossa Senhora foram se revelando centrais: a imagem de Maria - suas principais características físicas, de acordo com a descrição do vidente e com base na imagem esculpida a partir desta descrição exposta na capela das aparições de Jacareí -; e sua personalidade - captada a partir das mensagens atribuídas a Nossa Senhora e das interpretações dadas a elas pelos participantes: a fala do vidente, dos membros do grupo de apoio e dos peregrinos.

Desde já destacamos a existência de uma ambigüidade nas características de Nossa Senhora nesta aparição, coexistindo duas personagens em uma só figura: uma Maria frágil, doce, meiga e sorridente - como a sua imagem presente na capela das aparições - e outra forte, determinada, ameaçadora e preocupada, que surge principalmente nas falas que associam sua figura a previsões de castigos sobre o Fim dos Tempos.

A simbologia de Nossa Senhora é muito ampla, e a existência destas duas figuras reporta-se a manifestações do século XIX, ou ainda mais anteriormente, na idade média, não sendo novidades estabelecidas pelas aparições contemporâneas. No entanto, a coexistência destas duas características em uma mesma representação é interessante, e constatamos que isso somente é possível devido a importância atribuída à maternidade de Maria, é por ela ser mãe que pode ser frágil e forte ao mesmo tempo, protetora e ameaçadora, delicada, mas determinada, não representando isso uma ambigüidade para os fiéis. Começamos analisando a fragilidade da imagem de Nossa Senhora de Jacareí.

\section{1) A Fragilidade da Imagem}

Marcos descreve a imagem de Maria como uma jovem, quase adolescente, com cerca de dezoito anos. Ela é descrita como uma figura luminosa, jovem e sorridente, que somente se identifica como Nossa Senhora, mãe de Jesus, após dois anos de aparições. Até então era chamada de “jovem senhora”, ou “jovem luminosa”. Citamos aqui duas descrições da aparição, a primeira relatada por Marcos Tadeu e a segunda presente no livro “Maria nas aparições de Jacareí”, organizado pelo grupo de apoio das manifestações.

"Podia vê-la nitidamente: era uma jovem de uns dezoito anos, com um vestido levemente cinzento, puxando para o azul, um manto branco como a 
neve, uma coroa de doze estrelas na cabeça, uma longa faixa branca atada na cintura. Em suas mãos havia um terço de contas brilhantes e luminosas. Nunca vi uma mulher tão bela quanto ela. Docemente me fazia um sinal para que eu me aproximasse. Ela sorria, com aqueles olhos azuis inesquecíveis.”

Marcos Tadeu

"É belíssima, radiante, cheia de beleza e amor. Tem os cabelos negros como a noite, rosto suave, sereno, banhado de luz e doçura. Fala o português claro. Sua voz é melodiosa, celestial. Aparenta ter uns dezoito anos. Seu jeito de tratar é muito carinhoso, maternal. Vem com uma coroa de doze estrelas na cabeça, pequenos pontos azuis luminosos. Seu manto é de cor cinza azulado e o manto é de uma brancura maior do que a neve. Traz um longo terço de contas luminosas em suas mãos. Seus olhos são de um azul brilhante, fulgurante. Pousa no ar, em uma nuvem branca que não toca o chão.”

Passagem do livro “as aparições de Maria em Jacareí”

Página 23

As duas descrições possuem características muito semelhantes, pois já existe uma “descrição padrão” da Virgem de Jacareí. O vidente e os peregrinos, quando descrevem a aparição, ressaltam a juventude Nossa Senhora, bem como a sua suavidade e doçura. Todos os elementos descritivos contribuem para a constituição desta imagem doce e suave: seu rosto tem traços suaves, serenos, a sua voz é melodiosa, fala de forma carinhosa, exala um odor de rosas, ela tem olhos azuis brilhantes. Ou seja, a imagem da Virgem possui características muito meigas e suaves.

A imagem que observamos na capela do Monte das aparições procura seguir as características descritas, ela retrata uma jovem, com um rosário nas mãos e vestida com um manto cinza e uma coroa de estrelas na cabeça. A semelhança com a imagem de Nossa Senhora de Fátima é muito grande, ela também uma imagem de uma jovem, de traços belos e suaves, branca, quase loira, com um rosário em uma das mãos e o manto branco com uma coroa. A imagem de Nossa Senhora de Lourdes também não difere destas duas - é jovem, caucasiana e de traços suaves.

Assim, essas imagens da Virgem em aparições têm em comum a juventude e a suavidade, ela aparece como uma moça muito jovem, uma adolescente de cerca de dezoito anos em Jacareí, ou ainda mais jovem em Fátima e Lourdes -, descrita por 
Lúcia, a vidente de Fátima, como uma "rapariga de quinze anos” - ou por Bernadette, em Lourdes, como uma menina de doze anos.

Essas imagens de Nossa Senhora correspondem a um modelo que ressalta a feminilidade como doce e suave, sendo que Maria, como modelo desta feminilidade, possui estas características exacerbadas. Todos os adjetivos utilizados em sua descrição contribuem para formar uma imagem de doçura.

Nesse sentido, a idade descrita nas aparições corresponde ao momento em que Maria, segundo a crença católica, recebe a anunciação, ou seja, é informada por meio de um anjo que vai gerar um filho de Deus. É também a partir da anunciação que a postura de submissão de Nossa Senhora diante de Deus começa a ser formada.

Esses pontos merecem ser aprofundados. As características da imagem de Maria em Jacareí - juventude, suavidade e doçura - correspondem a um modelo de mulher. Esse modelo, por meio destas características, reporta-se ao relato bíblico da anunciação e às interpretações dadas a ele. A juventude de Maria corresponde ao período em que ela recebe a visita de um anjo - Gabriel - que lhe anuncia que ela gerará um filho de Deus - e, principalmente, é o momento em que ela aceita ao plano de Deus, dizendo sim para o anjo.

Segundo Pelikan (2000), a resposta de Maria ao mensageiro de Deus “cumpra-se em mim segundo a sua palavra” - "sem mencionar explicitamente a palavra fé, suas palavras identificaram a palavra "fé" com obediência, e a descrição de sua obediência à palavra de Deus fez dela um modelo de fé” (2000:39). Assim, a anunciação é o momento em que Maria diz "sim” ao plano divino, tornando-se modelo de fé e obediência. A aparição de Jacareí, ao destacar características de Maria que se reportam a anunciação, carrega consigo essa simbologia, ou seja, a Virgem é o modelo de obediência e submissão ao plano divino.

Esse modelo que associa fé, juventude, suavidade, obediência, submissão está presente não apenas na descrição física de Maria, mas também no discurso dos peregrinos. Podemos constatá-lo principalmente quando os devotos classificam Nossa Senhora como "humilde", sendo esta uma característica constante e normalmente relacionada à obediência. Eles consideram que Maria, apesar de ter sido “A Escolhida” por Deus - fato que poderia levar a soberba ou arrogância - sempre foi uma mulher humilde, sendo que esta humildade é constatada pela sua aceitação, ou seja, obediência, aos desígnios divinos - não apenas durante a anunciação, mas em toda a sua vida, aceitando até mesmo o que é percebido como a suprema dor para uma mulher ou para 
uma mãe: a morte de seu filho na cruz. Segundo os devotos, Maria aceitou com resignação todos os sofrimentos imputados por Deus a ela e a seu filho, por isso ela é modelo de obediência, quietude, resignação.

Voltando para o tema da anunciação, esta é uma das poucas passagens bíblicas em que Maria é mencionada, havendo raras passagens sobre sua figura no novo testamento. Embora o culto de Maria tenha passado por um grande desenvolvimento através dos séculos, possibilitando a existência de grande número de denominações e as diversas especificidades de suas devoções, alguns destes elementos são originários dos relatos bíblicos e das interpretações realizadas a partir deles, como o "sim” de Maria, que a transforma em um modelo de fé para toda a humanidade, e em um modelo de obediência e submissão feminina.

Inclusive, a anunciação é um dos momentos mais retratado nas artes plásticas, existindo um grande número de obras inspiradas neste relato bíblico. $\mathrm{O}$ renascimento é o período áureo de Maria nas artes plásticas, em que ela foi intensamente retratada, sendo que o tema da anunciação se sobrepõe a todos os demais. Grandes mestres do Renascimento possuem obras chamadas “Anunciação”, como Leonardo da Vinci, Fra Angélico, Botticelli, entre outros. Todas essas obras retratam uma Maria muito jovem, quase uma menina, e, geralmente, em uma postura de obediência, submissão e até mesmo de medo diante da aparição do anjo.

A interpretação da submissão de Nossa Senhora ao "plano divino”, ou seja, a aceitação em gerar o filho de Deus, é realizada pela teologia católica e constituída ao longo dos séculos, em que o seu "sim” é considerado como a aceitação da vontade divina, a submissão aos desejos do Pai. Ela é também observada nas obras sacras que retratam esse momento, em que Maria é uma jovem de aspecto frágil, assustada com a aparição do anjo, mas disposta a cumprir a sua parte no "plano divino”.

Nesse sentido, a juventude de Maria é o período de sua vida associado à submissão a vontade divina. A jovem da anunciação é frágil e delicada, como na imagem das Virgens das aparições, especialmente de Jacareí, em que as características de sua delicadeza são exacerbadas e a sua humildade e obediência destacadas. Assim, estas características estão interligadas na construção da figura de Maria em Jacareí: fragilidade, delicadeza, obediência, humildade. Estas são as características da mulher modelo de fé, modelo de obediência e modelo de humildade. A Virgem descrita por Marcos Tadeu carrega toda essa simbologia. Ela é a Virgem jovem, frágil e submissa da anunciação, aquela que diz sim ao Senhor. 
Entretanto, também na anunciação começa a se configurar outra simbologia de Nossa Senhora: a "mulher forte" ou "mulher de coragem". Essa aparente ambigüidade entre uma imagem frágil de Nossa Senhora e a atribuição de características consideradas fortes a sua personalidade são constitutivas da sua figura ao longo dos séculos. Maria, apesar de única, possui várias denominações e devoções, sendo que em cada uma delas determinados elementos possuem centralidade. As aparições analisadas são interessantes por que há a convivência destas duas características - a fragilidade e a fortaleza - em uma mesma denominação mariana.

\section{2) A Mensagem e suas interpretações}

"Sou a verdadeira mãe e a verdadeira intercessora de vocês junto ao trono de Deus, junto de Jesus...

Eu lhes digo filhos: os dias e os tempos em que eu posso salvá-los são agora! Se adiarem a sua conversão será tarde demais... Muitos dos meus filhos já estão afastados da Igreja, longe do verdadeiro caminho, vivendo nos erros, no vício, nos pecados... No meio de vocês ainda há muitos que transpassam meu coração! Eu continuo sofrendo por cada filho meu que vive nos vícios, na indiferença, na falta de oração...

Eu sou o auxílio dos cristãos, eu sou a mãe sempre solícita, sempre disposta a lhes ajudar, a lhes dar a paz. Encham-se de esperança, de amor, de oração! O Espírito Santo em breve virá sobre a terra e purificará. Mas nesta poderosa intervenção estará também a condenação dos maus.

Vocês vêem seqüestros, roubos, prostituição, violências que explodem de todos os lados. Estes são os sinais que indicam estar perto a volta do filho do homem. Meu TRIUNFO está às portas! Aquele que não estiver em oração sucumbirá. Aquele que estiver internamente podre cairá.

Por isso, meus filhos, eu imploro que orem, que se convertam. Que não me façam mais chorar lágrimas de sangue por vocês, mas voltem o quanto antes para Deus. Rezem o Rosário todos os dias! O que está segurando os castigos é o Rosário! ”

Mensagem de 25/05/96

Optamos por começar este item com uma mensagem transmitida pelo vidente Marcos em Jacareí e atribuída a Nossa Senhora, e, apesar de longa, concentra 
várias características associadas à Maria nas aparições, e que surgem, neste caso, através da voz da própria Virgem - na concepção dos participantes.

Analisaremos cada um destes elementos, utilizando, para isso, não apenas a fala de Maria, mas também a fala do vidente e a fala dos peregrinos, ou seja, as interpretações dadas pelos participantes para a figura de Nossa Senhora. Nesse sentido, veremos que os elementos de destaque se repetem no discurso dos diferentes atores, e estão presentes na mensagem anterior, em que contatamos quatro características importantes atribuídas a Maria: a maternidade, a mediação, o sofrimento e o combate.

\title{
A) Maria: Mãe
}

"Eu Sou a mãezinha de cada um de vocês. Eu não me alegro com a condenação dos pecadores. Choro quando se condenam e me alegro quando se voltam a mim. Eu sou a ternura de Deus. Venham meus filhos, construamos a era do amor...”

Mensagem de 12/03/1994

\begin{abstract}
"AMO-OS, meus pequeninos! Vejo as suas dificuldades, vejo os seus sofrimentos, vejo a cruz que cada filho meu carrega... Meus queridos filhos, não desanimem diante das dificuldades que o inimigo põe em seu caminho. Quero AMÁ-LOS cada vez mais com o meu coração de mãe”.
\end{abstract}

Mensagem de 07/04/1995

A maternidade de Maria é a característica mais destacada nas falas de Jacareí, como podemos observar nas mensagens anteriores. Nossa Senhora se dirige aos homens os chamando de "meus filhos", "filhinhos", "queridos filhos". Assim, embora o dogma da maternidade de Maria a coloque como mãe de Deus e da Igreja, nas aparições de Jacareí ela é percebida principalmente como mãe da humanidade, e não da humanidade de forma genérica, mas, nas palavras dos participantes como "mãe de cada um dos homens". Ela "vê a cruz que cada um carrega", ou seja, tem olhos para cada um de seus filhos individualmente.

Além disso, as falas de Maria são extremamente doces e carinhosas perfeitamente compatíveis com a imagem analisada no item anterior. A maternidade está associada ao carinho, ao afeto, Maria se dirige de forma afetuosa aos homens, usando adjetivos carinhosos, como queridos, amados, entre outros. E, como mãe, dirige- 
se especificamente a cada um deles. Ela é percebida como a mãe gentil, meiga, carinhosa e preocupada com cada um de seus filhos.

Nesse sentido, a idéia de que Nossa Senhora se manifesta devido a ser a mãe da humanidade é muito recorrente. Como mãe afetuosa, ela está preocupada com a salvação de cada um de seus filhos e por isso vem lhes avisar da proximidade do fim dos tempos. Na concepção dos participantes, é o fato dela desejar a salvação de seus filhos que explica as suas aparições, ela vem lhes avisar da importância de uma vida sem pecados para conseguirem a salvação.

Esta explicação dos devotos traz em si outra característica importante de Maria nas aparições: a mediação. Ela sabe dos planos de Deus, e por isso vem a terra para avisar aos homens, e, ao mesmo tempo, intercede por eles diante de Deus. Ou seja, os dois papéis estão bastante alinhavados nas aparições recentes: Maria, segundo os participantes, manifesta-se cada vez mais por ser mãe da humanidade - estando preocupada com a salvação de seus filhos - e por ser a mediadora entre a terra e os céus - informando aos homens dos planos de Deus.

Antes de nos aprofundarmos na maternidade de Nossa Senhora nas aparições, devemos destacar que ambas as características de Maria são bastante antigas no catolicismo. Apesar das poucas passagens e referências sobre ela na bíblia - exceção feita ao Evangelho de São Lucas ${ }^{74}$-, ela se tornou um dos maiores ícones do catolicismo - e mesmo do cristianismo e ao menos uma referência sobre os evangelhos deve ser destacada: as passagens que relacionam Maria como mãe de Jesus, e, portanto, mãe de Deus. No relato que ficou conhecido como a visitação, em que Maria vai visitar sua prima Isabel, ela se refere à Maria como a “mãe do meu senhor”. Foi a partir dessa passagem que o Concílio de Éfeso, em 431, transpõe a expressão de Isabel à Maria para o preceito de Maria como Theotokos - mãe de Deus.

Entretanto, quando nos referimos à maternidade de Maria entramos em um campo em que vários paradoxos estão presentes e permanecem atuantes, pois Maria é mãe e virgem, mãe de Deus, mas mãe humana de Deus - aspecto fundamental para seu caráter de intermediária entre os homens e Deus, como veremos adiante, bem como mãe da Igreja e da própria humanidade. Todos esses aspectos constituem a sua maternidade, e permanecem centrais quando nos referimos às aparições de Nossa Senhora. O primeiro deles, e aparentemente o mais paradoxal, o fato de Maria ser Mãe e Virgem,

\footnotetext{
74 Sao Lucas é o único dos evangelistas que traz referências maiores à Maria, sendo que alguns historiadores consideram que Maria tenha sido uma de suas fontes.
} 
será aprofundado quando tratarmos da mediação Mariana. Devemos nos referir, primeiro, ao fato dela ter sido considerada a mãe de Deus, fato que remonta ao Novo Testamento e aos primeiros anos da cristandade, especialmente no oriente, onde adquiriu o título de Theotokos, mãe de Deus.

Segundo Pelikan (2000), esse título foi acompanhado de grandes polêmicas, pois etimologicamente, Theotokos não possuía o significado simples de “mãe de Deus”, mas o significado preciso de "aquela que deu a luz a Deus", e a principal polêmica devia-se à crítica de que esse título daria a blasfema impressão de que Maria havia dado a luz à própria natureza divina, o que a aproximaria das divindades-mães do paganismo. Entretanto, é justamente para relembrar a dupla natureza de Cristo - humana e divina que foi justificada a proclamação de Maria como Theotokos, sendo ela a humana que deu a luz a Cristo, e garantindo, pois, a natureza humana de Jesus - ao lado de sua natureza divina, garantida pela paternidade do Espírito Santo. Assim, Maria é a mãe de Deus, mas a mãe humana de Deus, que também possui e herda sua dimensão humana.

Entretanto, Maria no cristianismo e no contexto das aparições não é considerada apenas a Mãe de Deus e/ou de Jesus, ela é a mãe da Igreja, e, principalmente, a mãe da humanidade. Mais do que isso, ela é a mãe de cada um dos homens, existe uma dimensão individual, a identificação de Maria como minha mãe por cada um dos seus devotos. Ela é, pois, a mãe de todos e de cada um. E, segundo a expressão recorrente nas aparições, como qualquer mãe, ela possui uma preocupação e uma dedicação especial com cada um de seus filhos. Há, pois, uma extensão da maternidade de Maria para cada homem, ela não e apenas mãe da humanidade, ela é a mãe de cada individuo, ela sabe as dores e as necessidades específicas de cada um de seus filhos. Isso somente é possível devido a sua dimensão humana, apesar dela pertencer ao plano divino, ela é capaz de perceber e se preocupar com as aflições dos homens.

Nesse sentido, na explicação presente nas aparições, o fato de Maria ser mãe de todos os homens relaciona-se com a sua característica de mediadora. Ela traz recados e transmite notícias do Reino dos Céus para os humanos por que se preocupa que todos consigam a salvação, considerada como a obtenção do Paraíso. Nas palavras dos participantes, ela quer cada um de seus filhos ao seu lado, e ao lado de seu filho Jesus, no Paraíso. Assim, nas falas de Jacareí, Maria é sobretudo mãe, em uma concepção que associa maternidade e carinho, afeto. A forma com que se dirige aos homens é afetuosa, bem como a forma como eles se dirigem a ela - ela é a "mãezinha querida” de cada um 
deles, e, como mãe afetuosa “conhece” cada filho, ela sabe as suas necessidades, angústias e tristezas específicas, pois, “para toda mãe, cada filho é especial e único”. É Maria mãe dos homens, minha mãe, a referência constante ${ }^{75}$, ela é próxima, íntima, humana - e não divina e distante.

Alem disso, ser mãe, na concepção dos participantes também implica em uma grande dimensão de preocupação e de proteção a seus filhos. Por isso nas aparições Maria está preocupada com os homens devido à proximidade do Juízo Final, ela quer protegê-los dos castigos previstos para o fim dos tempos - a dimensão escatológica das aparições será analisada a seguir.

Dessa maneira, a maternidade de Maria é parte importante da explicação sobre as aparições, em uma percepção da maternidade como amor, carinho, preocupação e proteção dos filhos. Nossa Senhora encarna, nesse sentido, um modelo de maternidade, possuindo as características consideradas inerentes a uma boa mãe. Ela é o modelo de perfeição, inclusive como mãe, é a mãe perfeita, carinhosa, doce, próxima, acessível, preocupada e protetora.

Interessa notar que, junto a esta concepção de Maria Mãe, há também uma concepção de indivíduo. Os homens, como filhos de Nossa Senhora, são únicos $e$ amados por ela. Esta concepção faz os devotos sentirem-se amparados, pois cada um se percebe como único e especial para a Virgem. Segundo eles, para Maria, como boa mãe, cada filho seu é único, ela "conhece” cada um deles, suas necessidades e angústias. A frase "você é especial para Maria”, é constantemente repetida nos Cenáculos, fazendo parte inclusive de um cântico.

A exclusividade do amor de Maria torna cada devoto único, amado e especial. A partir dos sentidos da maternidade de Maria ocorre, pois, a valorização do indivíduo nas aparições - sendo cada um percebido como amado e exclusivo para a mãe.

No entanto, não podemos deixar de considerar que ela somente tornou-se mãe da humanidade como uma extensão de sua característica de mãe de Jesus. Assim, Maria a princípio foi considerada Mãe da Igreja, por ter sido a primeira a acreditar no plano de Deus, desde a anunciação do anjo, quando teve fé nos fatos anunciados, até o

\footnotetext{
${ }^{75}$ Na verdade, nas aparições marianas, a figura de Nossa Senhora como mãe constantemente presente é a de Maria como mãe da humanidade, e apenas esporadicamente é lembrada sua dimensão de mãe de Jesus, e menos ainda a de mãe de Deus. Claro que a dimensão de Maria como mãe de Deus está presente afinal este é um dos quatro dogmas católicos referentes a Nossa Senhora - mas ele é pouco mencionado durante as manifestações
} 
momento da crucificação de seu filho, quando, apesar do sofrimento, acreditava e sabia previamente de sua redenção.

Entre os devotos das aparições, Maria é mãe dos homens, mas também participa do plano divino. Para eles, Maria é, por um lado, a mãe preocupada com a salvação de seus filhos, mas, por outro lado, ela também é a mãe de Deus, está ao seu lado nos céus e tem conhecimento de seu plano para a humanidade. Portanto, ela se manifesta para avisar aos homens sobre os planos de Deus. Ou seja, a sua maternidade está diretamente relacionada a seu papel de mediadora entre os céus e a Terra, entre Deus e os homens. Assim, apesar da referência direta dos devotos ser a Maria como mãe dos homens, embutida nessa idéia está também a sua maternidade divina, não apenas pela primeira ser decorrente da segunda, mas por justificar suas aparições e reforçar seu papel de intermediária entre os dois mundos.

\section{B) Nossa Senhora: a Mediadora}

"Eu os quero muito, e sabem que eu desejo conduzi-los pela estrada da santidade. Eu estou com vocês, e os conduzo pelo caminho do AMOR verdadeiro de Deus”.

Mensagem de 29/04/1995

"Queridos filhos, quero dar-lhes o meu AMOR e os benefícios da minha intercessão. Sou a verdadeira mãe e a verdadeira intercessora de vocês junto ao trono de Deus, junto de Jesus.”

Mensagem de 24/05/1996

"Filhinhos, sou a mãe de vocês! Guardo-os dentro do meu coração Imaculado! Que de hoje em diante nada aflija os seus corações, pois eu sou a companheira de vocês. Caminho com vocês junto a Jesus. Eu os amo e estou sempre orando por vocês junto a Ele.”

Mensagem de 14/07/1997

A mediação de Nossa Senhora está diretamente relacionada à sua maternidade. São duas características que estão profundamente intrincadas no discurso dos participantes das aparições de Jacareí, Maria intercede pelos homens, os conduz ao reino de Deus, pede por eles diante dele por ser considerada mãe dos homens. Ela 
realiza as intercessões, media as relações entre os homens e Deus por ser mãe. Em todas as falas citadas há a menção a sua maternidade, ela se coloca como mediadora e mãe.

A relação entre a maternidade de Nossa Senhora e a sua intermediação estão presentes desde o inicio da devoção a ela no cristianismo, e se devem a natureza de Maria, entre divina e humana. Segundo Pelikan (2000), na arte ortodoxa do Oriente, nos primeiros séculos do cristianismo, Maria é retratada como divina, pois divina era a palavra exata para designá-la como Theotokos. Entretanto, sua natureza divina não advém de seu nascimento, ela nasce humana, mas eleva-se, durante a sua vida, à natureza divina. Ela, enquanto Theotokos, ocupava uma posição especial, nas palavras de Pelikan: "Ela certamente fora menor que Deus, mas não se pode negar que também fora maior que um ser humano comum e mais importante que qualquer outro santo." (2000:143). Essa posição especial havia sido adquirida, ela não era parte de natureza divina, mas tornara-se parte dela, ou seja, não possuía uma natureza divina preexistente, como no caso de Cristo, tendo sido totalmente humana em sua origem, como todos os demais seres humanos. Nesse sentido, segundo o autor, “por ter sido escolhida por Deus para ser a Theotokos, sua natureza completamente humana fora transfigurada e ela se tornara, ainda em sua existência humana e de modo singular, participante da natureza divina”. (2000:149).

Dessa maneira, o papel de mediadora assumido por Nossa Senhora deve-se a esse seu aspecto dúbio, entre ser humana e ser divina. O lugar que a teologia católica a colocou, e que é constantemente reproduzido pelos seus devotos na atualidade, é de que Maria encontra-se “abaixo apenas de Deus”. Ou seja, sua natureza divina não é aceita, ela não é divina, mas foi o ser humano que mais dela se aproximou e justamente por isso ela é um modelo para a humanidade, modelo de ser humano perfeito que alcançou um lugar ao lado de Deus.

Foi no auge da idade média, pelos séculos VII e VIII, que se desenvolveu a doutrina da mediação de Nossa Senhora, tendo aparentemente origem oriental. Foi esse também um período de intensa devoção à Virgem Maria, nas palavras de Pelikan " $a$ glória de seu nome invadiu o mundo inteiro”, sendo que o que diferenciou a devoção e o enfoque desse período dos anteriores foi a crescente ênfase no seu papel de mediadora. Porém, o que se entendia desse papel desempenhado por Maria? Podemos relacionar ao menos dois aspectos da mediação: Nossa Senhora representava a mulher “por meio de quem nos elevamos a ele, e pela qual Deus desceu a nós, é, pois, por quem nós podemos ter acesso ao filho”. O termo “mediadora” se referia a esses dois aspectos 
da condição de Nossa Senhora, era esse o modo de mencionar seu papel na encarnação e na redenção. Ela foi a responsável pela encarnação de Jesus, ao obedecer e tomar parte no plano de Deus e, conseqüentemente foi possível a Redenção do Senhor. Ela possui, então, para a teologia desse período, um papel ativo na história da salvação.

Por outro lado, Maria é mediadora também devido a sua intercessão entre Cristo e a humanidade, e não somente por seu papel na história da salvação. Vale lembrar que, durante os rituais que acompanham as aparições, bem como para os devotos, é a intercessão de Maria que se referem quando a mencionam como Mediadora. Para Pelikan, entretanto, essa devoção a Maria como intermediária dos homens advém, justamente, de sua participação na redenção, sendo devido a ela que Nossa Senhora foi considerada teologicamente como a segunda dignitária, “abaixo apenas de Deus que nela havia feito sua morada”. Ela, pois, passa a ser considerada mais importante que qualquer ser humano comum e que qualquer santo, devendo receber os louvores do mundo inteiro. Nossa Senhora assume, então, por sua enorme santidade, o papel de mãe misericordiosa nas horas de necessidade e aflição, sendo poderosas as preces que lhes são endereçadas, pois ela as levará a seu filho Jesus. É essa característica constantemente destacada nas aparições de Jacareí, a colocação de que Maria está abaixo apenas de Deus. Esse é o seu lugar, abaixo de Deus e acima dos homens, por isso ela é capaz, por um lado, de conduzir os homens no caminho de Deus - pois ela é humana e realizou este caminho - e, por outro lado, de pedir, orar pelos homens diante de Deus - pois ela está ao seu lado no reino dos céus.

Assim, a dimensão humana de Maria é fundamental para a sua mediação. Ela é humana como cada um dos homens e mulheres que lhe dirigem as preces pelo mundo todo, pois “Ela Jamais poderia ser verdadeiramente mediadora a menos que também fosse humana (...) Maria não poderia ter sido o arquétipo de todos os remidos a menos que também fosse um deles” (2000:201). Dessa forma, essa dimensão humana explica a sua mediação, e também a extrema identificação e proximidade que os devotos sentem pela Virgem Maria. Ela foi humana, sofreu e foi feliz como cada um deles.

Além disso, é Mãe, de todos, mas também de cada um individualmente. Ela, como mãe e como humana é considerada capaz de perceber, de sentir, de se compadecer das agruras passadas por cada um de seus filhos. O sofrimento dos homens a toca por que ela é mãe, mas também por que ela foi humana, sofreu das dores do corpo e da alma, por isso a grande proximidade e intimidade dos devotos em relação à Maria. 
Esses dois papéis são intensamente destacados nas aparições marianas. Nossa Senhora é mãe da humanidade, mãe humana, e não apenas mãe espiritual, por isso entende de fato os sentimentos de cada um de seus filhos, que também são seus iguais. Por outro lado ela também é mãe de Deus, e está ao seu lado nos céus, tendo poder e influência sobre seu filho divino, e por isso pode intermediar tão bem as preces que lhe são dirigidas por seus filhos humanos.

Na mediação, pois, a maternidade e a humanidade de Maria são destacadas, e dela emerge uma concepção de indivíduo entre os devotos, como mencionado no item anterior, como únicos e especiais. Além disso, eles se percebem como seus iguais, pois compartilham da mesma natureza humana que Maria. O valor e a importância da individuo aparecem constantemente na simbologia mariana acionada pelos fiéis.

A aproximação entre as características de Nossa Senhora e as características dos homens vai se tornando explícita nas falas e crenças dos participantes, e demonstram a importância da figura de Maria para eles, sendo que, ao enfocarem as características da Virgem, enfocam também suas próprias características como humanos.

Outra característica importante de Nossa Senhora é que ela não é uma figura passiva ou submissa, pelo contrário, ela é ativa, ela é aquela que se mobiliza para que os pedidos de seus filhos sejam atendidos, para que a sua salvação seja possível. Assim, a sua obediência e aparente submissão não se manifestam como passividade. Como observado na primeira mensagem, ela é a condutora dos homens. Há uma ambigüidade, quase uma incoerência na personalidade de Maria. Por um lado, há ênfase na característica "humilde” de Maria pelos participantes, para eles a sua humildade está relacionada à sua aceitação do plano divino, desde a anunciação até a crucificação. No entanto, por outro lado, ela também surge como mulher ativa nas falas sobre as aparições, como aquela que interfere no destino dos homens, que os conduz. Segundo os fiéis, apesar dela não poder interferir nos desígnios divinos - Deus é considerado mais poderoso do que Nossa Senhora, é ele que decide o destino da humanidade - ela toma o partido dos homens e vem à terra para avisá-los. Dessa forma, nas aparições, apesar de ser uma figura doce e meiga, ela é atuante, ela assume uma postura ativa, de interferência na vida e destino de seus filhos.

A explicação central dada para as aparições pelos participantes - vidente, grupo de apoio e peregrinos - é que elas acontecem devido a preocupação de Nossa Senhora com a salvação de seus filhos. Ou seja, para eles Maria tem conhecimento dos 
planos de Deus para o mundo - pois ela pertence ao mundo divino - e por isso vem ao mundo dos homens, para avisá-los do futuro. Ela é, pois, por um lado, mediadora pertence aos dois “mundos”, transitando e transmitindo informações e pedidos entre eles - e por outro lado mãe, sendo a maternidade associada à busca do bem estar dos filhos, somente possível, na concepção dos devotos, por meio da salvação.

Mãe e mediadora, eis dois papéis centrais assumidos por Nossa Senhora nas aparições. Papéis que possuem profundidade histórica, mas que possuem importantes sentidos para os peregrinos das aparições contemporâneas.

\section{C) Maria: Mater Dolorosa e Mulher de Coragem}

Meus filhos, hoje quero dizer-lhes que estou muito triste, e o meu coração está muito ferido... (aqui ela interrompe e chora) Estou passando por angústias por causa dos pecadores. Peço aos meus filhos que ofereçam orações para me consolar.

Mensagem de 20/02/1994

Maria não se conforma com os pecados cometidos pelos homens, que impedem a sua salvação, e por isso vem a terra. A possibilidade da perdição das almas causa um intenso sofrimento em Nossa Senhora, ela, como mãe, sofre por saber do futuro de aflições destinado a seus filhos. Segundo os participantes, a maior dor de uma mãe é "ver os filhos sofrerem”. Essa explicação, no contexto das aparições, refere-se aos pecados cometidos pelos homens que os levaria ao inferno - que representa o sofrimento eterno no catolicismo. Então Maria aparece para lembrá-los da importância do abandono do pecado.

A imagem de Maria triste, chorando, sofrendo é constante nas falas dos participantes das aparições, e a principal causa de sua dor são os pecados cometidos pelos homens, que “ferem seu coração”, provocam-lhe sofrimento, pois eles podem levá-los à perdição. Ela é vista como a mãe que sofre e se angustia pela possibilidade de perdição de seus filhos. Essa concepção é constantemente utilizada para explicar as suas aparições, ela, por estar angustiada com a possível perdição das almas, vem fazer-lhes pedidos de oração, para que possam alcançar a salvação. Segundo os devotos, Maria sofre por cada um de seus filhos. 
O sofrimento de Nossa Senhora nos remete a sua imagem como Mater Dolorosa: Maria ao lado de seu filho após a crucificação, o intenso sofrimento vivenciado por ela. Nos relatos sobre as aparições Maria também sofre por seus filhos pecadores, que a fazem derramar “lágrimas de sangue”, expressão máxima da dor.

Nesse sentido, a representação de Maria como Mater Dolorosa surge no mesmo período histórico que a concepção dela como mediadora. Nesta representação Maria lamenta a morte de seu filho, sofre diante das provações que são impingidas a ele durante a via cruxis. Representações da Mater Dolorosa florescem por toda a Europa, sendo que a mais célebre é a Pietá, de Michelangelo, que captura a profundidade da dor de Maria sustentando o corpo de seu filho em seus braços, dando expressão artística à profecia bíblica de Simeão: “uma espada trespassará a tua própria alma”, que segundo Pelikan (2000), desde séculos anteriores era considerada como uma referência à experiência pela qual Maria passaria como a mais atingida testemunha da crucificação e morte de Jesus.

Inclusive, a Mater Dolorosa é tema de várias visões marianas durante a Idade Média, como nas revelações de Nossa Senhora a Santa Birgitta, na Suécia, em que Maria relata seus sofrimentos; e à Santa Teresa de Ávila, nas chamadas Angústias de Nossa Senhora, em que a Quinta Angústia é simbolizada por Maria segurando o corpo de seu filho. Já nas manifestações contemporâneas a imagem destacada é a do sofrimento de Nossa Senhora pelos pecadores, mas a associação com a maternidade permanece. Assim como ela sofreu pelo flagelo de Jesus, sofre com os pecados dos homens, pois sabe que estes os levarão ao "sofrimento eterno", ou seja, suas almas "se perderão”, estarão condenadas ao inferno. Assim, como a mater dolorosa sofreu diante dos sofrimentos de seu filho Jesus, Maria nas aparições sofre por ter conhecimento dos sofrimentos destinados a seus filhos pecadores.

Além disso, a preocupação de Maria com as aflições dos homens gera uma sensação de amparo para os devotos. Eles consideram que "podem contar" com a Virgem, que ela “não lhes abandonará”. Ou seja, apesar de nas mensagens o sofrimento de Nossa Senhora ser uma forma de repreensão aos homens por seus pecados, ele também serve para lembrá-los de que Maria está do seu lado, que se preocupa e sofre por eles. Assim, nos momentos de aflição é para ela que os devotos se voltam, pois acreditam que, mesmo sendo pecadores, podem contar com a sua compreensão.

Novamente destacamos a ambigüidade da figura de Maria, desta vez como Mater dolorosa, por um lado ela remete a submissão de sua figura, desde a anunciação, 
quando ela aceita ser mãe do filho de Deus, ela diz sim para todo o plano de Deus, ou seja, sabe e aceita todas as dores e sofrimentos que serão impingidos a ela e a seu filho. Assim, Nossa Senhora das Dores é a imagem daquela que sofre em silêncio pelas agruras impostas a Jesus, ela é a imagem do "sofrer calado", da quietude, aceitação e submissão. Isso transparece nas mensagens e nas falas dos participantes das aparições de Jacareí, Maria é muito doce, meiga, a imagem da mãe que sofre e chora por seus filhos, sem desespero, mas mansamente, com quietude e passividade.

Por outro lado, justamente por ser mãe, e por sofrer por seus filhos, ela desempenha também um papel ativo, em busca da salvação dos homens. Dessa forma, ela aparece nas mensagens e no discurso dos participantes como brava, como guerreira, como mulher forte, mulher de coragem. Ela luta bravamente em defesa de seus filhos, ela deseja que todos eles obtenham a salvação e por isso toma a frente de batalha. $\mathrm{O}$ sofrimento da possível condenação de seus filhos ao inferno não a leva a passividade, mas ao combate, ao desempenho de um papel ativo e forte.

\section{D) Maria: a guerreira}

Meus filhos rezem o Rosário todos os dias. Meus filhos, o Rosário será a grande arma.

Meus filhos, eu lhes dei muitos dons, e agora peço que os coloquem em prática, a fim que o meu TRIUNFO possa acontecer com urgência. Rezem.

Meus filhos, hoje eu venho pedir que aumentem as orações! Rezem para que eu TRIUNFE.

Rezem que em breve o meu TRIUNFO virá.

Mensagens de Março de 1994

"Neste ano minha luta será mais decisiva contra o dragão, pois agora o tempo dele já está contado em poucos grãos. O tempo caminha depressa para o meu triunfo. Tudo o que eu disse desde Fátima até agora se realizará e o mundo encontrará um novo tempo de paz.”

Mensagem de 07/01/1998

Nas mensagens e na fala dos participantes a figura de Maria como guerreira, como Mulher de Coragem, ativa, que empreende uma guerra contra o inimigo representado por Satanás - é muito recorrente. No vocabulário utilizado por eles as 
metáforas relacionadas à guerra, ao combate são abundantes e muitas vezes destacadas, como é o caso da palavra triunfo, que aparece sempre com letras maiúsculas no livro que contém as mensagens de Maria em Jacareí, além de outras metáforas comuns, como arma, luta e vitória.

Assim, na aparição de Jacareí existe a representação de um combate, liderado por Nossa Senhora, contra Satanás e contra os pecados. Nesta guerra a maior arma são as orações dos homens, elas são capazes de salvar as almas para Deus, ou seja, as orações contam ponto para o lado “do bem”, para Deus na batalha contra o mal representado por Satanás e pelos pecados. Por isso, nesta batalha, os homens são considerados os "guerreiros de Nossa Senhora”, cuja arma de combate são as orações, especialmente o Rosário, sendo que a líder deste exército é a Virgem.

Na concepção dos participantes a batalha já está ganha, ou seja, o Triunfo de Maria já está garantido, ela será a grande vitoriosa. Por que a guerra, então, se a vitória já esta determinada? Embora a batalha final seja considerada ganha, ocorre uma disputa pela alma dos homens - em torno da salvação ou da condenação de cada um deles. Assim, mesmo considerando que Maria sairá vitoriosa, quanto mais almas estiverem do lado de Deus - ou seja, quanto menos pessoas cometerem pecados e quanto mais elas orarem - maior será o seu triunfo e menor o seu sofrimento - pois serão menos almas “perdidas para o inimigo”.

Nesse sentido, dois aspectos devem ser destacados: A Vitória final de Maria e a sua disputa pela alma dos homens. No caso do combate, novamente a importância da maternidade é reiterada, desta vez em um papel ativo. Maria aparece por que quer o bem de seus filhos - representado pela salvação de suas almas - que somente poderá ser obtido pela conversão e pelo abandono do pecado - analisaremos as características deles a seguir. As aparições são consideradas, então, uma forma de aviso de Nossa Senhora, ela, como mãe, resolve tomar uma atitude para que os homens se voltem para o "lado do bem”. Sob esse aspecto, a característica que se destaca não é a passividade, pelo contrário, é a atividade, ela se manifesta, ela toma uma atitude para defender seus filhos. Maria é concebida como uma mulher forte, guerreira, capaz de liderar um exército contra Satanás para que a alma de seus filhos seja salva.

Essa figura de Maria como guerreira, como mulher de coragem também não é nova no catolicismo. Apesar do papel de submissão e obediência que lhe foi associado, ambiguamente, a sua imagem de mulher forte também esta presente no imaginário católico há muitos séculos. Assim, como paradigma da submissão temos a 
concepção de Maria como “Serva do Senhor”, a que obedeceu aos desígnios divinos - a imagem da anunciação é um dos temas mais recorrentes das cenas da vida da Virgem Maria retratados artisticamente. No entanto, para contrabalançar a interpretação submissa que carrega a concepção de Maria como “Serva do Senhor”, a descrição medieval - período em que ambas surgiram - acrescentava a idéia da Mulher de Coragem - Mulier Fortis. Segundo Pelikan, o termo advém do livro dos Provérbios, e foi assim interpretado. "Mulher de coragem tornou-se então uma notável designação e metáfora para identificar Maria como guerreira e campeã, como conquistadora e líder” (2000:129). Nesse sentido, segundo o autor, as duas interpretações surgem no mesmo período, e justamente para se contraporem e se contrabalancearem.

Além dos Provérbios, e com maior influência, foi o livro do Gênesis que forneceu os fundamentos para a concepção guerreira de Nossa Senhora. Especialmente a passagem "E porei inimizade entre ti e a mulher, entre a tua descendência e a dela, ela te ferirá a cabeça e tu lhe ferirás o calcanhar”. Os teólogos desse período consideram que Nossa Senhora é a mulher mencionada, sendo a serpente considerada o Demônio, e a vitória de Maria dada como certa. Ela é a mulher que vencerá a serpente do mal. Inclusive, essa relação entre a Virgem e a mulher mencionada no livro do Gênesis é constantemente observada em representações artísticas desde então.

Nesse sentido, as representações que associam Nossa Senhora, a mulher do Gênesis e a "Mulher vestida de sol” mencionada no Apocalipse de São João são comuns a partir de então. A mulher do Apocalipse combate e vence o dragão, que nas interpretações populares representa o Demônio - assim como a serpente o representa no livro do Gênesis. Essa tripla associação não está presente apenas na teologia, mas em pinturas e tapeçarias do período. Assim, essas duas imagens da mulher vitoriosa foram associadas à Maria e estão presentes no imaginário católico, explicando as inúmeras denominações de Nossa Senhora como vitoriosa, guerreira, combatente, ou seja, como mulher forte.

A certeza de seu triunfo está, pois, relacionada a estas duas passagens bíblicas, que prevêem a Vitória da Mulher - Maria - sobre a serpente e sobre o Dragão - Satanás. Essa interpretação é recorrente nas aparições da atualidade. Nossa Senhora é considerada a vencedora do inimigo - o pecado. Nesse sentido, Maria é percebida como a mãe guerreira, a brava defensora da humanidade, a combatente incansável do pecado. Ou seja, à concepção do triunfo de Nossa Senhora é acrescentada a sua percepção como 
defensora e líder dos homens contra o inimigo. E, para isso, a imagem utilizada é a da mulher do Apocalipse, a mulher vitoriosa sobre o dragão ${ }^{76}$.

Assim, Maria por sua obediência e submissão é considerada o ser humano perfeito, o modelo a ser seguido, porém, por outro lado, como mãe é defensora dos homens, é a mulher que toma alguma atitude para que seus filhos obtenham a felicidade eterna. Ou seja, ela é submissa e obediente aos planos de Deus, mas essas características não a levam a passividade, pelo contrário, Maria é forte, corajosa, guerreira. Junto com a imagem doce e singela, da suavidade marcante de algumas falas atribuídas a ela está a figura de uma mulher determinada a brigar pela felicidade de seus filhos, capaz de enfrentar um dragão e pisar em uma serpente para defendê-los.

Dessa maneira, em muitas das mensagens atribuídas a Nossa Senhora ela oscila entre sofredora, padecendo e chorando pelos pecados dos homens, e ameaçadora, lembrando aos homens os castigos pelos quais passarão se não “obedecerem a Deus” -, abandonando o pecado, de que trataremos mais adiante.

Assim, associada a sua característica guerreira surge uma Virgem ameaçadora, a própria mulher do apocalipse, que defende os homens, mas que também os adverte dos sofrimentos previstos caso não “abandonem o pecado”. Ou seja, Maria é uma forte defensora de seus filhos, mas também os ameaça com dolorosos castigos, lembrando-os de sua responsabilidade, da sua escolha - o livre arbítrio - entre o “caminho do bem”, livre do pecado e que os conduzira a salvação, e o "caminho do mal”, o pecado que os conduzira ao sofrimento eterno.

Nesse sentido, embora Maria sofra e se mobilize por seus filhos, ela também mostra que eles são os responsáveis pelo seu futuro, ameaçando com dolorosos castigos aqueles que optarem pelo pecado. Os homens, além de responsáveis pelo seu futuro, são considerados “guerreiros da Virgem”, estando a seu lado na "batalha”, e cuja principal “arma” é o Rosário. Há, pois, uma concepção ativa da humanidade; se Maria lidera o exército contra o pecado, os homens são os seus guerreiros, responsáveis não apenas pela sua própria salvação, mas também pela salvação de outros homens, por meio da conversão e do abandono do pecado. Esse tema será aprofundado a seguir, por hora basta reiterarmos a característica ativa e guerreira de Nossa Senhora, a qual está associada à característica também ativa e guerreira de seus devotos.

\footnotetext{
${ }^{76}$ Inclusive, a imagem da mulher vestida de sol está, desde a Idade Média, relacionada com as visões marianas, sendo muito recorrente. Nas palavras de Pelikan: "Literalmente, milhares de aparições semelhantes foram relatadas ao longo dos séculos” (1996:240).
} 
Assim, da simbologia guerreira de Maria emergem sentidos que atribuem valor aos indivíduos, sendo que eles, como Maria, possuem um papel ativo na história da salvação. Eles são importantes no combate ao pecado, um exército não obtém a vitória sem seus guerreiros, Nossa Senhora precisa dos homens na sua batalha. Assim, cada indivíduo é percebido como importante e com valor.

Dessa forma, neste item analisamos símbolos marianos recorrentes nas aparições - a maternidade, a mediação e o combate - demonstrando que eles pertencem a um imaginário de longa duração no catolicismo. Entretanto, esses elementos não são meros arcaísmos, pelo contrário, a eles são também incorporados elementos importantes para os indivíduos na atualidade, fazendo com que eles ganhem sentido no mundo contemporâneo.

Neste ponto apresenta-se um outro tema importante das aparições de Nossa Senhora: a visão apocalíptica. Maria é a mulher do apocalipse, e junto a ela todas as demais profecias presentes no Apocalipse de São João são lembradas pelos participantes. Eles consideram que Nossa Senhora se manifesta devido à proximidade do final dos tempos, ao fato de que estamos vivenciando os “últimos dias”. Há, pois, uma dimensão milenarista e escatológica nas aparições de Jacareí, bem como em outras manifestações de Nossa Senhora, como analisaremos a seguir.

\section{3) Nossa Senhora e o Fim dos Tempos}

A humanidade se afastou de Deus e agora peca horrivelmente. Já não agüento mais segurar o braço da justiça divina. Meu divino filho está prestes a descarregar sua justa ira sobre o mundo.

Rezem e façam penitência se quiserem ser salvos. Pratiquem com rapidez esta mensagem. Não ofendam mais a Deus, que já está por demais ofendido...

Mensagem de 14/02/1994

"Esta tempestade que vocês vêem não é nada perto dos castigos. Será cem vezes pior do que isso. Que vocês se convertam e rezem, pois muitos não sobreviverão quando vierem os castigos. Raios se abaterão sobre a terra e muitos serão fulminados.”

"O castigo se aproxima. Corpos de pessoas explodirão no ar. Rezem.”

Mensagens de Setembro de 1998 
“Quarto mistério 'O carregamento da Cruz’, em Jacareí nas aparições Maria Santíssima repetiu diversas vezes que essas são as últimas aparições para a humanidade, depois destas, ela nunca mais ela virá outra vez. Este tempo é o tempo da misericórdia em breve ele acabará, e começará então, o tempo da justiça inexorável seguido de um tempo de paz duradoura.”

Marcos Tadeu

"Nossa Senhora diz que é a última, ela não vai mais aparecer, e que as mensagens de Fátima ela diz que não foram ouvidas, e que é a última chance do mundo, então ela tá fazendo algumas aparições e ela conclui agora e depois dessas aparições, ela diz que vai haver um triunfo do coração de Maria. Vai ter um sinal, são três sinais, o primeiro as pessoas ainda tem a chance de se converter e depois do segundo não vai haver mais essa chance, mas ela não conta como vai ser esses sinais, mas ela diz que vão acontecer, as mensagens de Fátima foram pra preparar o mundo, pra que mundo melhorasse pra que acontecesse esse triunfo.”

Peregrina Sandra

Nas falas anteriores podemos perceber que as aparições de Nossa Senhora estão relacionadas com a crença na proximidade do final dos tempos. Segundo eles, Nossa Senhora vem se manifestando cada vez mais a partir do final do Século XIX para avisar aos homens da proximidade do Juízo Final, para lembrar que já estamos vivendo os últimos tempos, e por isso os homens devem orar e se converter, para se salvarem dos castigos previstos no Apocalipse.

A escatologia nas aparições de Jacareí é um elemento central, que as justifica e estabelece a continuidade com outras aparições marianas. Segundo os participantes, Maria avisa aos homens da proximidade do Fim dos Tempos desde aparições muito anteriores, como La Salette e Fátima, sendo que ela intensifica e continua suas manifestações por que os homens não atenderam ao seu pedido, ou seja, não pararam de pecar, não se converteram e por isso estão prestes a sofrer “toda a ira de Deus Pai”.

Dessa maneira, a atmosfera apocalíptica percorre a fala dos participantes e as mensagens de Nossa Senhora, sendo elas repletas de elementos presentes na escatologia, na crença na proximidade do final dos tempos. Vale a pena aprofundar os elementos escatológicos das aparições. 


\section{1) Os elementos escatológicos das aparições}

As mensagens com características escatológicas estão presentes nas aparições de Nossa Senhora desde o momento em que elas ganharam centralidade no catolicismo, durante o século XIX. Philippe Boutry (1997), importante estudioso das aparições francesas, considera a formação de um modelo a partir deste período, que chama de "modelo Francês", estabelecido após a aprovação de três aparições por diferentes bispos: La Salette (1846), Lourdes (1858) e Pontmain (1871). A base de atestação deste novo modelo, segundo o autor, é o vidente, considerado "um inocente" as três visões ocorreram para crianças pastoras. O modelo desenvolvido por este autor é interessante, pois demonstra que a característica comum entre estas visões são os videntes, sendo que o conteúdo das manifestações possui diferenças ${ }^{77}$.

Segundo Boutry, a dimensão escatológica está presente nas aparições desde La Salette, mas a aparição considerada de ruptura é Fátima, em que o caráter ameaçador das mensagens é central. O seu estudo faz um apanhado de várias aparições marianas desde a Idade Moderna até a atualidade, em diferentes contextos. Trata-se de uma antologia das manifestações, mas que considera duas delas "de ruptura", por estabelecerem elementos que exerceram influência sobre os fenômenos posteriores: Fátima e Garabandal.

Interessa destacar que estas duas aparições são consideradas centrais para os devotos de Jacareí - pelos organizadores e pelos peregrinos - e que possuem a dimensão escatológica em destaque. Para Boutry, estas são as aparições que possuem maior força apologética, influenciando os fenômenos seguintes.

Para demonstrar a centralidade destas duas aparições para o fenômeno de Jacareí citamos o exemplo de duas mensagens, colocadas em destaque na contra capa do livro sobre estas aparições: “A aparição de Fátima é o início... Este lugar é a conclusão das mensagens de Fátima...” - mensagem atribuída a Nossa Senhora, em 18/06/94 -; "A confirmação e a continuação de Garabandal" - mensagem de Maria em 24/02/2000. As duas citações demonstram a importância delas para os organizadores do

\footnotetext{
${ }^{77}$ Boutry estabelece uma divisão entre as aparições a partir deste modelo: as aparições que têm como foco o milagre - cujo exemplo é Lourdes - e as aparições em que o foco está nas mensagens, geralmente de caráter escatológico - cujo exemplo é La Salette. Embora nas duas aparições os dois elementos - milagre e mensagem - estejam presentes, a essência da aparição está em apenas um deles. Em Lourdes é a água milagrosa, a presença das curas milagrosas é fundamental, sendo que as mensagens de Maria são pouco mencionadas. Já em La Salette a ênfase está na fala da Virgem, em seu conteúdo escatológico.
} 
livro - pertencentes ao mesmo grupo que organiza os rituais - e também a relação de continuidade estabelecida entre as aparições ${ }^{78}$.

Nas falas de Marcos durante os Cenáculos também percebemos esta relação de continuidade entre as aparições marianas, colocando em destaque Fátima e Garabandal. Durante vários rituais o vidente se referiu as aparições de Jacareí como “ $a$ conclusão das mensagens de Fátima"; ou como a "confirmação de Garabandal”; sempre afirmando que as aparições locais seriam as últimas - Jacareí é considerada a "última chance da humanidade, pois Maria vem nos avisando desde Fátima”.

Percebemos que a conexão e continuidade são estabelecidas pela crença na proximidade do Juízo Final, sendo por esse motivo que Nossa Senhora aparece para os humanos. Assim, as aparições consideradas inaugurais pelos participantes são aquelas em que as mensagens ameaçadoras sobre o Fim dos Tempos são marcantes, no caso Fátima ou La Salette. Na maioria das vezes é a aparição de Fátima referida como “o início” destas manifestações de Maria, mas a aparição de La Salette é também mencionada em alguns relatos ${ }^{79}$. Por outro lado, as aparições em que a dimensão escatológica não está em destaque são pouco referidas, como Lourdes, por exemplo, que embora seja o Santuário de aparição mariana mais visitado do mundo, nunca é mencionada como o início da série de manifestações de Nossa Senhora.

Sob esse aspecto, Boutry considera que a aparição de Fátima estabelece uma ruptura, marcada pelas mensagens ameaçadoras, que se repetem na grande maioria das manifestações seguintes ${ }^{80}$. $\mathrm{O}$ autor não usa o termo escatologia, mas se refere às aparições "em que não há uma solução construtiva para o pecado, apenas ameaças" (1997:322). Segundo ele, são raras as aparições pós-Fátima que tragam mensagens de esperança, sendo o modelo da ameaça, semelhante ao da visão portuguesa, que influencia a maioria das visões do período pós-guerra - o autor cita vários fenômenos em que as referências à condenação iminente da humanidade são constantes ${ }^{81}$.

\footnotetext{
78 Importa reiterar que estas são as únicas mensagens presentes na capa do livro, demonstrando a importância destas duas aparições para os devotos.

79 As duas aparições têm muitos traços semelhantes, especialmente as mensagens ameaçadoras. Isso foi percebido ainda durante as aparições de Fátima, que, embora hoje sejam mais conhecidas e visitadas do que La Salette, na época era chamada de La Salette portuguesa. Inclusive, durante os interrogatórios dos videntes de Fátima foi questionado se eles conheciam a história da aparição francesa.

${ }^{80} \mathrm{O}$ autor demonstra essa dimensão ameaçadora em várias aparições de Nossa Senhora pós-Fátima.

${ }^{81}$ Importa mencionar que Bouflet é também um importante teólogo mariano e crítico de muitas aparições de Nossa Senhora, inclusive de Medjugorje. Enquanto René Laurentin desempenha o papel de teólogo defensor das aparições na atualidade, Philippe Boutry condena a grande maioria delas. Estes dois teólogos têm uma grande divergência sobre a aparição de Medjugorje.
} 
A segunda aparição de grande força apologética, segundo Boutry, foi Garabandal, na Espanha, que disseminou um novo elemento: a crítica ao clero. Assim, as mensagens aterrorizantes permanecem, mas são acompanhadas de fortes críticas aos sacerdotes - responsáveis pela rejeição da aparição pela Igreja.

Segundo o autor, estas duas aparições ainda influenciam as manifestações contemporâneas, citando como exemplo Medjugorje, em que as mensagens ameaçadoras e as críticas ao clero são centrais. Importa destacar que estes dois elementos são também observados nas aparições de Jacareí, principalmente o tom ameaçador das mensagens, como nos exemplos citados no início deste item.

Dessa forma, os elementos escatológicos são centrais nas aparições marianas, estabelecendo a conexão e a continuidade entre elas, devido à influência de duas aparições “de ruptura” - Fátima e Garabandal -, justamente as duas aparições que, junto com Medjugorje, são presença constante nos depoimentos dos devotos e nas falas dos Cenáculos.

Devemos agora compreender em que consiste a escatologia, quais as suas características e elementos e quais deles são acionados nas aparições de Jacareí.

\section{2) A Escatologia}

Segundo Jean Delumeau (1995), em sua obra dedicada ao milenarismo, as crenças na finitude da humanidade, precedidas de mil anos de felicidade sobre a terra, encontram fundamentação no antigo testamento e no Apocalipse de São João, estando presentes na Igreja Católica desde a Antiguidade - período em que as estas crenças estavam em alta no cristianismo ${ }^{82}$. Esse autor faz uma reconstituição da presença do milenarismo ao longo da história, enfocando o mundo ocidental e cristão em diferentes períodos - antiguidade, renascença, século XIX, entre outros - demonstrando como as crenças escatológicas estão presentes em diferentes momentos e em diferentes movimentos; no catolicismo, no protestantismo e inclusive no pensamento de pensadores laicos, estendendo-se até a contemporaneidade.

Embora não seja nosso intuito traçar uma história da escatologia, trabalho desenvolvido com profundidade por Delumeau, importa-nos reter, com referência a esta

\footnotetext{
${ }^{82}$ Segundo este autor, as crenças milenaristas passam por uma regressão a partir de Santo Agostinho considerado o liquidador do milenarismo cristão primitivo por estabelecer que os santos e os pecadores estarão misturados na cidade de Deus até o dia do julgamento final, não abrindo margem para qualquer possibilidade de um Reino de Deus, repleto de felicidade, neste mundo. Apesar disso, segundo Delumeau, a tradição escatológica no Reino de Deus sobre a terra sobrevive de forma um pouco marginal, ressurgindo com forca no século $\mathrm{X}$.
} 
obra, que os elementos que compõem estas crenças são muito semelhantes nas diferentes épocas e contextos. Estes elementos são observados nas aparições da Virgem Maria desde o século XIX. Ou seja, as aparições marianas possuem uma atmosfera apocalíptica devido à repetição de uma série de elementos historicamente relacionados com a escatologia.

Jacques Le Goff (2003) é outro estudioso que faz uma análise histórica das idéias escatológicas, especialmente nas religiões judaico-cristãs, nas quais surge o termo escatologia. No sentido adotado pelo autor - e que será utilizado neste trabalho -, a escatologia está sempre ligada à idéia de um tempo final. Sob esse aspecto, o autor divide as religiões com idéias escatológicas em dois tipos: teleológicas e de eterno retorno, mostrando as diferenças na concepção do tempo final por cada uma delas. As teleológicas são as que concebem o tempo linearmente e, portanto, nas quais a história tende para um fim único e inevitável. Já as do eterno retorno concebem o tempo ciclicamente, em que os fins são provisórios, sendo, na verdade, o recomeço do mundo, a volta às origens. Como nossa análise se dá no âmbito do catolicismo, a escatologia está relacionada à concepção de um fim único e inevitável para o mundo e, conseqüentemente, para a humanidade. Essa concepção fica clara nas falas mencionadas, em que a crença na proximidade do fim dos tempos é recorrente, trata-se da crença de que o tempo está se esgotando, chegando ao fim.

Entretanto, como bem coloca o autor, a escatologia possui, associada a ela, outras concepções que são constitutivas dos tempos finais e que têm variações, mesmo no âmbito do cristianismo, sendo importante fazer precisões e distinções para caracterizá-las. Existem três concepções constantemente ligadas à escatologia: o milenarismo, a apocalíptica e o Juízo Final. Segundo o autor, a apocalíptica nasceu no seio da escatologia, estando estritamente ligada a ela, em suas palavras “ $A$ escatologia foi se aperfeiçoando através de escritos de natureza profética que descreviam um apokalypsis, uma “revelação" dos acontecimentos do fim dos tempos.” (2003: 326). Assim, a apocalíptica constitui-se de textos de conteúdo profético, que revelam os fatos dos tempos finais.

Sob esse aspecto, nas mensagens de Jacareí a dimensão apocalíptica é constante, revelando acontecimentos que marcarão o final dos tempos, algumas vezes com detalhes dolorosos e assustadores. Nestas mensagens Maria surge como ameaçadora, como a portadora de verdades que condenam a humanidade a grandes sofrimentos. As revelações são dolorosas, sendo muitas vezes privadas, ou seja, 
reveladas apenas para os videntes, não podendo ser divulgadas devido a seu horror, aos detalhes cruéis que antecedem ao Julgamento Final.

As mensagens enfatizam um período anterior ao dia do Julgamento, durante o qual a humanidade, especialmente os pecadores, passará por uma série de provações. Essa é uma característica da apocalíptica, que enfatiza - inclusive no Apocalipse de São João -, que “entre o Aquém atual e o Além do fim dos tempos” existirá um longo período terrestre de prefiguração desse Além. Segundo o apocalipse, esse período deve durar mil anos, de onde advém o termo “milenarismo"83. O milenarismo, pois, “se centra sobre a parte do fim dos tempos que precede o fim propriamente dito; o seu programa é fatalmente político e religioso e, muitas vezes confunde esses dois níveis” $(2003: 327)^{84}$.

No caso das aparições, não existe um projeto delineado para a humanidade, mas sim uma série de profecias que descrevem com detalhes o período que antecede ao julgamento final. Embora não existam referências à duração deste tempo, os elementos milenaristas e apocalípticos são abundantes. Os participantes acreditam que já vivemos a prefiguração do Além, as profecias apocalípticas se referem justamente a esse período de transição. Importa destacar que as profecias revelam sofrimentos incríveis para a humanidade - para se ter uma idéia de sua dimensão, a expressão facial das videntes, durante o transe em que Maria lhes mostrava os castigos finais, é chocante, sendo capaz de demonstrar a extensão das dores destinadas à humanidade.

Nesse sentido, devemos destacar que, como colocado por Jacques Le Goff , existem peculiaridades referentes aos tempos finais, que podem ser marcadas por dois extremos: como tempos de grande felicidade, ou como tempos de enormes sofrimentos. São duas correntes, que afirmam que o conteúdo dos dias finais pode ser positivo acreditando na proximidade do advento e em uma idade de paz e felicidade - ou, contrariamente, negativo - que prega a iminência do castigo e do fim do mundo, não deixando escolha aos homens, apenas a urgência do arrependimento. No caso das

\footnotetext{
${ }^{83}$ Essa concepção de Milênio deu nome a várias crenças, teorias e movimentos assim classificados. A essa nova era está associada, muitas vezes, à vinda de um salvador ou guia, que ajuda na preparação para o fim dos tempos, chamado Messias na tradição judaico cristã, daí o termo messianismo, atribuído a movimentos milenaristas centrados em uma liderança.

${ }^{84}$ Delumeau demonstra esta dupla característica do milenarismo ao estudar movimentos laicos que se estruturam a partir de idéias presentes no milenarismo religioso - especialmente por possuírem um projeto de felicidade para toda a humanidade no plano terreste - como as utopias que deram origem a importantes correntes de pensamento do século XIX. Ou seja, a partir da analise destes dois autores podemos constatar que o milenarismo, ao pensar em períodos de felicidade para os homens na Terra, constitui planos ou projetos para a humanidade que apresentam dimensões políticas.
} 
aparições, o caráter negativo é marcante, a única saída para os homens é o abandono do pecado, podendo assim conseguir um futuro de felicidade, mas não neste mundo e sim no Reino dos Céus.

Assim, a crença em uma batalha final entre Deus e o Diabo, em que a vitória de Deus é garantida - por meio do exército liderado por Nossa Senhora - traz em si a expectativa de um futuro de felicidade para os homens - apenas para os considerados merecedores, pois os pecadores já terão sido punidos durante o Julgamento Final. Nesse sentido, há uma tensão entre a crença em um período de felicidade coletiva - após a vitória de Maria - mas que será, no entanto, precedido por um período de catástrofes.

A presença destas duas etapas, segundo Delumeau, é comum no milenarismo, existindo diferentes ênfases em cada uma delas pelos movimentos alguns deles são otimistas, enfatizando o período de felicidade dos homens e outros são extremamente pessimistas, destacando detalhadamente a fúria de um Deus vingador em punir a humanidade pecadora ${ }^{85}$.No caso das aparições marianas a ênfase está nas catástrofes e castigos que serão vivenciados pela humanidade, sendo a felicidade após este período mencionada, mas não descrita e profetizada detalhadamente como o pessimismo dos tempos finais.

Dessa maneira, as crenças escatológicas pessimistas, que enfatizam castigos e sofrimentos para a humanidade são constitutivas das aparições de Jacareí, estabelecendo um elo entre ela e outras aparições de Nossa Senhora, especialmente Fátima e Garabandal.

\section{3) Fátima: O início}

Começaremos nos detendo na centralidade atribuída a aparição de Nossa Senhora em Fátima, Portugal, no ano de 1917. Em todos os fenômenos marianos extraordinários de que participamos notamos não apenas a importância dessa visão, mas a concepção de ser ela o fenômeno inaugural, que dá inicio a vários outros eventos do mesmo tipo. Essa característica foi observada no discurso das pessoas ligadas às aparições, locuções e milagres - videntes, confidentes e participantes.

\footnotetext{
${ }^{85}$ Delumeau utiliza como exemplo a Itália do período renascentista, em que estavam presentes inúmeras correntes escatológicas "que misturavam a espera escatológica do fim do mundo e a esperança otimista em uma Idade do ouro cristã, ambas precedidas por grandes tribulações” (1995:92)
} 
A idéia de que Fátima foi um fenômeno inaugural, ao qual se sucederam vários outros, era constante nos rituais, na fala, nas publicações e mesmo nos sites católicos. Como podemos observar no seguinte depoimento:

Peregrina Olga: "Reiniciando o carisma” esse último livro do padre Jonas, e então ele tá falando do ciclo de Nossa Senhora (...) Nossa Senhora começou a aparecer em Lourdes, não, como foi gente, agora eu não lembro pra falar errado, acho que é Fátima ao meio dia, e Medjugorje ela aparece de tardezinha, então padre Jonas diz assim, que nós somos os operários da última hora, que nós estamos nos vinte minutos finais, está muito próximo da vinda de Jesus, ele está medindo isso pelas aparições de Nossa Senhora, que Medjugorje é vinte pra seis que ela aparece, então ele acha que são vinte minutos pra acabar o mundo, os últimos vinte minutos...

Este depoimento é ilustrativo, pois demonstra a conexão estabelecida pelos peregrinos entre as aparições de Nossa Senhora. Elas não estão isoladas, mas constituem um ciclo. Neste depoimento Olga apenas cita as aparições internacionais, entretanto, no primeiro capítulo demonstramos que a percepção da existência de uma continuidade entre as aparições marianas é recorrente.

Outro exemplo está presente no "Portal Anjo”, sendo atribuída a Maria em uma mensagem transmitida à confidente Vassula: "Vassula, Garabandal é a seqüência dos milagres. Entre um Milagre e outro tenho dado muitos outros sinais (...) Escreve alguns deles Fátima e agora quero que escreva "San Sebastian de Garabandal ${ }^{86 \text { ". }}$

Assim, notamos que apesar de Fátima não ter sido a primeira aparição de que se tem notícia, ela assume um papel de inauguração no imaginário sobre as aparições no Brasil. Para os devotos, ela dá início a uma série de manifestações de Maria aos homens, que permanecem até os dias de hoje, existindo um elo de

\footnotetext{
${ }^{86}$ Devemos destacar, entretanto, que a aparição ocorrida em Garabandal seguiu um caminho muito diferente do seguido por Fátima e por Lourdes - a segunda aparição citada. Enquanto ambas tornaram-se os maiores santuários marianos da Europa, sendo reconhecidas e apoiadas por representantes da Igreja, Garabandal, pelo contrário, foi intensamente combatida pela hierarquia católica local - especialmente pelo bispo de Santander, responsável pelo vilarejo - sendo, inclusive, proibida a celebração de qualquer missa na vila por mais de duas décadas. Somente na década de oitenta foi permitida a celebração de missas, mas não no local das aparições, apenas na vila. Em seguida analisaremos os elementos das aparições que contribuíram para esse desfecho, agora devemos reter que não se trata de um grande santuário - no local existe apenas uma capela e uma única loja de vendas de lembranças - e não possui destaque no âmbito do catolicismo em geral.
} 
continuidade entre as aparições de Fátima e todas as demais manifestações de Nossa Senhora ocorridas a partir de então.

\section{A Virgem em Fátima}

A aparição de Nossa Senhora em Fátima ocorreu entre maio e outubro de 1917, foram sete aparições, sempre no dia 13. Os videntes eram três pequenos pastores - Jacinta, de sete anos; Francisco, de oito anos; e Lucia, de 11 anos. Segundo a história, os três estavam a pastorear os animais quando ouviram um chamado, e, ao irem verificar, no local chamado “Cova da Iria”, percebem, em cima de uma azinheira, "uma senhora mais brilhante que o sol, com um terço branco nas mãos”. Na última aparição, em 13 de Outubro, estiveram presentes 70.000 pessoas na Cova da Iria, que presenciam o "milagre do sol” - momento em que o sol começa a girar sobre si mesmo - e que a senhora se apresenta como Nossa Senhora do Rosário. Atualmente, Fátima é um dos maiores santuários de peregrinação católica da Europa, sendo que cerca de quatro milhões de peregrinos passam anualmente pelo Santuário.

Esta pequena história possui uma série de elementos que se tornaram característicos das aparições em todo o mundo e que foram analisados. Entretanto, esta é a história oficial, aprovada e divulgada pelo Vaticano e pelos Sacerdotes, em que os elementos escatológicos não são mencionados, pois eles estão relacionados com o conteúdo das mensagens e segredos de Nossa Senhora, que, segundo os devotos, são previsões sobre os castigos destinados à humanidade nos tempos finais.

Interessa destacar que os elementos escatológicos foram ganhando centralidade ao longo do tempo, não estando presentes na primeira versão dos videntes sobre as mensagens, que não enfatizavam as profecias sobre os tempos finais, mas sim a oração, a conversão e a construção de uma capela - pedidos comuns nas manifestações de Maria desde a Idade Média. Entretanto, com o passar dos anos a vidente Lucia acrescentou elementos nas mensagens de Nossa Senhora, que, segundo ela, tinham sido “esquecidas” em seus primeiros depoimentos, relacionadas com previsões sobre o Fim dos Tempos, que ficou conhecida entre os teólogos como Fátima II.

Nesse sentido, parte dos elementos simbólicos associados à manifestação não estavam presentes nos primeiros relatos dos videntes sobre elas. Esse fato deu início a uma intensa polêmica envolvendo as aparições de Fátima, chamada pelos teólogos de Fátima I e Fátima II, sendo que apenas o primeiro momento das manifestações de 
Fátima - conhecido como Fátima I - foi reconhecido pela Igreja - trata-se da versão “oficial”: sete aparições, para três crianças, na Vila de Fátima em 1917.

Entretanto, apesar da polêmica, este segundo ciclo fundamenta parte importante do imaginário referente à Virgem de Fátima, sendo os elementos surgidos em Fátima II que estabelecem o tom ameaçador desta manifestação. Nas declarações posteriores de Lúcia os elementos escatológicos são preponderantes, havendo a associação entre a devoção ao Sagrado Coração de Maria e as previsões sobre a proximidade do fim dos tempos. Trata-se da imagem de uma Virgem ameaçadora, aterrorizante, que fala da ira de Deus e da punição dos pecadores, que se estabelece e se dissemina pela Europa e pelo Brasil. Nas aparições brasileiras, especialmente no caso de Jacareí, é justamente a previsão sobre o final dos tempos a característica lembrada pelo vidente e pelos fiéis quando se referem à Virgem de Fátima.

Interessa notar como a história repetida pelos devotos no Brasil, nas aparições marianas brasileiras, refere-se a "história oficial”, ou seja, a aparição da Virgem numa azinheira para três crianças, porém, usa todo o imaginário escatológico, bem como a devoção ao Sagrado Coração de Maria, surgida depois de 1917. Não existe uma distinção entre elas, somente no plano teológico há o debate sobre a legitimidade de Fátima II, pois no plano das devoções não há distinção ou mesmo conhecimento sobre elas.

Importa lembrar que os novos elementos de Fátima somente foram revelados no momento anterior a Segunda Guerra, em 1942. Segundo Boutry, a aparição serviu aos interesses políticos desde muito cedo, acabando por se tornar uma aparição anticomunista e antisoviética, devido à declaração de Lúcia sobre a necessidade da “consagração da Rússia ao Sagrado Coração de Maria”, tornada pública antes da segunda guerra e recuperada durante a Guerra Fria. Entretanto, desde antes desta declaração os padres portugueses, traumatizados com a situação trágica da Igreja na Espanha durante a guerra civil, oravam para Nossa Senhora de Fátima proteger o país do comunismo.

Até o momento da guerra a aparição de Fátima não exercia nenhuma influência sobre outras aparições, sendo a partir da divulgação dos temas de Fátima II que estes começaram a afetar outras manifestações. Assim, aos temas escatológicos de Fátima II são atribuídos sentidos políticos, que demonizam a Rússia e o comunismo, fazendo sentido, então, no momento da Guerra Civil espanhola - em Portugal - e da Guerra Fria - em todo o mundo. 
Segundo Boutry, os elementos escatológicos de Fátima, a visão do inferno, a consagração da Rússia ao Sagrado Coração de Maria “conferem a Fátima um dinamismo sem precedentes: oitenta anos depois, Fátima continua um caso único na história das mariologias, que pode ser considerado como um “antes de Fátima” e um “após Fátima”, definidos pela divulgação de Fátima II em 1942” (1997: 301). Entretanto, apesar de Boutry notar a importância do contexto sócio-político na divulgação das aparições de Fátima e a influência de seus temas sobre as aparições posteriores, ele não aborda os motivos da permanência desta influência nas manifestações contemporâneas, apesar da mudança no contexto. Dessa maneira, no final deste capítulo devemos analisar por que os elementos escatológicos permanecem centrais nas aparições marianas contemporâneas no Brasil.

\section{4) Garabandal: a continuação}

As aparições de San Sebastian de Garabandal são sempre lembradas pelos peregrinos quando ocorre a menção ao "fim dos tempos". A presença de elementos escatológicos, em tom bastante aterrorizante, é marcante desta aparição, sendo que sempre as menções sobre ela destacam a proximidade dos tempos finais e o terror que será instalado no planeta nos últimos dias.

Garabandal é a aparição considerada como a continuidade do tipo de fenômeno inaugurado em Fátima, sendo percebida como o segundo ponto da “seqüência de milagres” iniciados, segundo os crentes, em Portugal. Essa relação foi estabelecida por participantes das diversas manifestações extraordinárias de Maria e está também presente em sites católicos que se referem às aparições marianas, como os sites “Portal Anjo” e o "Deus fala conosco”. Em ambos existem espaços exclusivos dedicados as aparições de Garabandal, sendo, inclusive, a aparição mais destacada pelos provedores do "Deus fala conosco".

O papel de continuidade dos eventos inaugurados em Fátima é patente, bem como o fato de não ter sido uma manifestação conclusiva, mas que possui destaque entre uma série de aparições, e à qual as aparições posteriores sentem-se tributárias. Destacamos mais um exemplo, elaborado pelo Pe Jonas Abib, líder da RCC, e publicado em seu livro "Maria: a mulher do gênesis ao apocalipse”, em que ele destaca o chamado “ciclo de Maria”, já mencionado neste capítulo, em que coloca a 
aparição de Fátima como o início, a aparição de Garabandal como a continuação e a aparição de Medjugorge como a conclusão das aparições marianas mais reveladoras ${ }^{87}$.

Dessa forma, a afirmação de Phillippe Boutry de que Garabandal é a aparição com maior força apologética desde Fátima é observada nas aparições de Jacareí e também entre os devotos de aparições marianas no Brasil. Isso fica claro no exemplo anterior, que pontua Fátima, Garabandal e Medjugorje como aparições chaves. No caso de Fátima demonstramos que a influência ocorre por meio dos elementos escatológicos, que são repetidos e aprofundados em Garabandal.

As aparições em Garabandal começam em 1961 e se estendem durante cinco anos, sendo mais de duas mil mensagens transmitidas a quatro videntes - Conchita, Mari Loli, Jacinta e Mari Cruz. Como na aparição de Fátima, são quatro meninas camponesas, que avistam Maria sobre alguns Pinheiros, no campo.

As mensagens possuem um tom ameaçador, como em Fátima II, enfatizando a chamada trilogia: aviso, milagre e castigo ${ }^{88}$. Nosso primeiro contato com informações sobre Garabandal ocorreu ainda durante o mestrado, pelo trabalho de campo realizado entre os carismáticos. Entre eles as referências à aparição de Garabandal eram comuns, destacando as profecias realizadas por Nossa Senhora sobre o final dos tempos, bem como o êxtase das videntes durante as profecias escatológicas e a visão do inferno. Ainda nesse período, entrevistamos uma carismática, devota e peregrina de Garabandal, que possuía o livro sobre as aparições, e se propôs a copiá-lo para mim, e realmente o fez, mas apenas o capítulo sete, justamente o que relata a trilogia. Este episódio nos deu a primeira pista de que o interesse dos carismáticos sobre Garabandal estava relacionado

\footnotetext{
${ }^{87}$ Neste livro, o autor não desconsidera a importância das aparições “menores”, mas destaca que as grandes revelações ocorreram nestes três fenômenos, sendo as demais apenas repetições de elementos revelados nestes locais. Tomamos conhecimento dessa concepção pelo contato com os carismáticos marianos - ela é constantemente repetida por eles e também vinculada pela rede carismática de rádio e TV "Canção Nova”.

${ }^{88}$ Todos os aspectos da trilogia referem-se a profecias sobre o final dos tempos. Elas constituem uma continuidade temporal linear, iniciada pelo aviso, continuada pelo milagre e tendo como fim o castigo que marca o dia do Juízo Final. Entretanto, percebemos que essa trilogia não é o único tema presente nas inúmeras mensagens, sendo o conteúdo delas bastante variado - às vezes banal e cotidiano, como sobre o novo corte de cabelo das confidentes. Inclusive, em uma das fontes - um livro sobre as aparições adquirido por uma informante em visita à vila espanhola - essa trilogia ocupa apenas um dos sete capítulos da obra, sendo finalizado com a seguinte nota: "as partes mais constitutivas das mensagens de Garabandal são: o amor à vida, oração, caridade, eucaristia e fidelidade à Igreja. A ênfase exagerada no castigo agrada Satanás por desviar a atenção dos demais elementos das mensagens”. Essa nota é bastante significativa, pois, apesar de demonstrar a preocupação dos autores com os outros elementos das revelações, já antecipa que as mensagens destacadas, bem como as interpretações dadas a elas, recaem sobre essa trilogia sobre o final dos tempos - ameaçadora e aterrorizante, e também muito polêmica. Nesse sentido, apenas uma parcela do enorme conteúdo das mensagens se refere à trilogia sobre os últimos dias - justamente o que destacado pelos devotos.
} 
com as mensagens escatológicas, não apenas com o conteúdo delas, mas com todos os fatores que cercaram o momento das revelações - a expressão das videntes, detalhes sobre seu êxtase, as condições da natureza. O restante das mensagens não é considerado central - não merecendo sequer ser copiado.

A partir da análise de outras fontes também percebemos a centralidade dessa trilogia, como no site "Portal Anjo" - sendo ela o elemento que perpassa todo o texto sobre esta aparição, existindo, inclusive, fotos das videntes em êxtase durante as profecias sobre o aviso.

Já o site "Deus está conosco" atribui ênfase ainda maior na trilogia e nos aspectos ameaçadores das profecias. Além do destaque especial para as aparições de Garabandal - são várias páginas dedicadas a ela, em um ícone de destaque na página inicial do site - todo o texto presente, bem como as fotos, reporta-se ao aviso, ao milagre e ao castigo ${ }^{89}$. Importa neste ponto destacar que há forte crítica aos sacerdotes associadas à trilogia, sendo que um dos sinais da proximidade do final dos tempos é a “corrupção” do clero. Como na seguinte mensagem:

“Agora o cálice está a transbordar. Muitos cardeais, bispos e padres estão no caminho da perdição e conduzindo muitas almas”

Junto ao aspecto ameaçador, há o questionamento das autoridades da Igreja. Na verdade, as críticas ao clero compõem e completam a escatologia da aparição, pois, refutar a autoridade da Igreja e de seus representantes é um elemento bastante comum nos movimentos centrados na proximidade do fim dos tempos ${ }^{90}$.

Nesse sentido, autores demonstram que essa dimensão está intrinsecamente ligada à escatologia, sendo que os movimentos e grupos que atribuem papel central à escatologia tendem a questionar e às vezes mesmo romper com a autoridade exercida pela Igreja Católica. Segundo Jacques Le Goff (2003), houve na própria Igreja uma corrente escatológica que identificava a Igreja Romana com a babilônia, a grande prostituta, sendo seu primeiro teórico Joaquim Del Fiori, no século XII.

\footnotetext{
${ }^{89}$ Existem várias fotos e também filmagens que mostram o transe das videntes durante as revelações de Nossa Senhora sobre a trilogia, em que suas expressões de horror e medo diante do que lhes era revelado possui destaque.

${ }^{90}$ Os questionamentos às autoridades da Igreja dificultou a aceitação e o apoio da Igreja às aparições de Garabandal.
} 
Garabandal foi a manifestação mariana que deu início às criticas ao clero, sendo que a partir dela, em outras aparições, críticas severas aos sacerdotes foram emitidas, inclusive destinadas nominalmente aos sacerdotes locais. Assim, a escatologia de Garabandal se completa com o enfrentamento das autoridades locais da Igreja ${ }^{91}$.

Sob esse aspecto, Phillippe Boutry novamente relaciona o aprofundamento da dimensão escatológica e as críticas ao clero ao momento religioso vivenciado, logo após o Concílio Vaticano II, que havia suprimido três importantes festas marianas e atrelado à devoção a Maria com a devoção a Jesus Cristo, fato que causou reação negativa de alguns setores do catolicismo. Segundo Boutry, essa reação repercutiu sobre algumas manifestações pós-conciliares na forma de críticas alarmistas ao clero, da qual a aparição de Garabandal é paradigmática - no que se refere à intensidade das profecias e à severidade das críticas aos sacerdotes. Para este autor, Garabandal é a segunda aparição de ruptura, devido a sua grande força apologética e a influência exercida por ela sobre as manifestações posteriores.

Concordamos com a importância e a influência desta aparição sobre os fenômenos posteriores, inclusive as manifestações marianas contemporâneas no Brasil, porém, a análise realizada pelo autor não explica o porquê da continuidade de sua força apologética na atualidade, visto que o contexto sócio-religioso atual não é semelhante ao pós-conciliar, lembrando, inclusive, que ela sequer foi reconhecida pela Igreja, sendo mencionada apenas entre grupos carismáticos e de devotos de aparições.

Nas duas aparições os elementos escatológicos estão relacionados com o contexto. Embora sejam elementos de longa duração no catolicismo, eles são acionados em momentos e contextos específicos, passando a exercer influencia sobre os outros fenômenos a partir de então. Resta-nos compreender por que estes elementos são acionados nas aparições de Jacareí.

\section{5) O Final: Por que Maria aparece em Jacareí?}

Nos itens anteriores demonstramos que a crença na proximidade do Julgamento Final serve como justificativa para as aparições de Nossa Senhora. Elas não

\footnotetext{
${ }^{91}$ Entretanto, não houve o questionamento ou afronta à sua autoridade maior - o Papa -, pelo contrário, uma das maneiras de reforçar sua pertença ao catolicismo é afirmando a obediência ao Vaticano.
} 
são percebidas como manifestações isoladas de Maria, mas como conexas, havendo uma continuidade entre elas. Em Jacareí a manifestação de Nossa Senhora é considerada “a conclusão de Fátima e a continuação de Garabandal”, sendo que esta relação de continuidade é estabelecida devido às previsões escatológicas atribuídas à Virgem em Fátima, intensificadas em Garabandal e repetidas em Jacareí.

Nesse sentido, várias “evidências” são citadas pelos participantes para demonstrar que vivemos os últimos dias. Para eles, as mensagens de Nossa Senhora desde Fátima enfatizam este fato e várias características do mundo atual servem para “provar” a iminência do Fim dos Tempos. O principal deles é a proliferação do “pecado” pelo mundo; segundo eles, o “Deus nunca tinha visto tantos pecados no mundo como hoje em dia".

A menção aos inúmeros pecados remete-se aos textos apocalípticos que afirmam que na fase anterior ao Julgamento Final Satanás será libertado, causando muitos males e levando a humanidade ao pecado. Isso é percebido, segundo eles, nas características presentes na atualidade, destacando comportamentos morais - como o adultério, o sexo fora do casamento, a falta de respeito com os mais velhos - a presença da violência - as guerras, a violência urbana, assassinatos, assaltos e tráfico de drogas a mídia - responsabilizada pela transmissão de "pornografia”, ou seja, de comportamentos considerados imorais, como insinuação de sexo nas novelas, romances adúlteros, palavrões, entre outros - as músicas - que, como a mídia, divulgam comportamentos considerados inadequados, pecaminosos - o comportamento da juventude - que não respeita mais os pais, somente pensa em diversão, em sexo, em álcool e em drogas - as catástrofes climáticas, como inundações, poluição, furacões todas consideradas de responsabilidade humana e/ou de Satanás, demonstrando a degradação que a ganância do homem é capaz de realizar na natureza.

Dessa forma, existe uma ampla gama de fatos considerados pecaminosos, evidenciando a proximidade do final dos tempos, todos os fatores que causam algum tipo de sofrimento para os homens - como as guerras, a violência e as catástrofes climáticas - bem como uma série de comportamentos cotidianos considerados inadequados - como o sexo fora do casamento, novelas, músicas e o uso de álcool - que compõem o repertório de "pecados”. Assim, para estas pessoas, o dia a dia é capaz de mostrar como o mundo "anda errado".

Nesse sentido, a responsabilidade pelo mundo de pecados é atribuída, por um lado, a Satanás, que está à solta pelo mundo, e por outro lado, aos homens, que 
pecam o tempo todo. Há uma forte condenação do "mundo" atual no discurso dos participantes, sendo as características deste “mundo" que o levarão a sua destruição por Deus. Assim, embora o julgamento final seja considerado inevitável, estando definido desde os primórdios, é o comportamento da humanidade que determinará este fim. Os homens são considerados responsáveis por desencadearem a Ira de Deus ao optarem pelo pecado, ou seja, os indivíduos têm escolha e são responsáveis por seus atos.

É interessante estabelecermos um contraponto com a RCC e com o neopentecostalismo neste ponto. A concepção de um combate entre o bem e o mal, assim como a concepção de que o diabo está solto pelo mundo estão também presentes no universo simbólico destas religiosidades. Entretanto, embora a banalização da presença de Satanás no mundo, bem como a sua associação aos sofrimentos da humanidade seja também estejam presentes, a responsabilidade do homem sobre o mal ou sobre o pecado é diminuída, pois para os carismáticos e neopentecostais a responsabilidade de todos os males e aflições que assolam a humanidade é de Satanás ${ }^{92}$.

92 Devemos detalhar um pouco mais as características de Satanás nestas religiões. Em nosso trabalho de mestrado sobre a RCC constatamos que a ação do mal opera por contaminação, por infecção. Na representação carismática, o mal é uma força que se encontra solta pelo mundo profano, sendo capaz de contaminar os homens. Mesmo o mais fiel dos carismáticos pode ser contaminado por ele, já que sua vida cotidiana se desenvolve no "mundo", em que a presença de Satanás é constante. Assim, ele é uma figura constantemente presente, corriqueira na vida dos fiéis.

Além disso, Satanás tem poder: poder sobre os homens e sobre a natureza. Ele é considerado o grande responsável por todo mal que aflija a humanidade, seja ele uma ocorrência natural ou devido à ação humana. Todas as tragédias físicas ou humanas - desde terremotos, enchentes, até a guerra, a fome ou um ataque terrorista - são atribuídas a Satanás. Assim, na RCC, o demônio apresenta uma face terrível e virulenta, sendo capaz de cometer grandes atrocidades contra a humanidade. Entretanto, em atitudes mais sutis também acreditam na presença de Satanás, como as depressões, as carências, além de fatos cotidianos, como programas de televisão e músicas. Onipresente, corriqueiro, banal, mas também terrível e poderoso, essas são as características atribuídas ao Demônio pelos carismáticos.

Nesse sentido, a concepção do mal na RCC aproxima-se da presente nas religiões neopentecostais, como a IURD. Autores que estudaram essas religiões destacam que em qualquer perturbação da ordem cotidiana identificam a presença de Satanás. Doenças, brigas, desemprego, alcoolismo, problemas financeiros ou qualquer infortúnio são considerados ações do demônio sobre a vida das pessoas. Ele é a razão de todos os males que afligem os fiéis. (Mariz, 1997; Birman, 1997, Gomes, 1994; Almeida, 2003). Nas palavras de Mariano, referente à IURD "pastores e fiéis enxergam atuação demoníaca nos acontecimentos mais insignificantes do cotidiano" (127:1996). Assim, de forma semelhante a RCC, o diabo é onipresente e banal, além de possuir poder de intervenção sobre a vida humana, sendo o causador de todos os malefícios ${ }^{92}$.

A dimensão rotineira e ameaçadora de Satanás no cotidiano dos homens não é nova. A face terrível e constante de Satanás remonta, segundo Nogueira (2000), à idade moderna, em que a teologia católica erudita buscava alertar a população contra a ação constante e terrível de Satanás no mundo ${ }^{92}$. Assim, a característica terrível de Satanás, bem como a sua presença em fatos inofensivos do dia a dia dos homens, é parte do repertório de imagens criadas pelos teólogos de idade moderna, não sendo portanto estranha ao imaginário popular, no qual qualquer heresia assumia formas demoníacas.

Essa mesma dimensão ameaçadora e banal de Satanás indica que "o demônio não é apenas a simbolização do mal, mas uma presença e evidência em todos os momentos” (Souza, 1986:101) Ele invade os menores espaços da vida, tomando a alma dos indivíduos. 
Satanás promove todas as desarmonias sobre a vida dos homens, sendo que a condição humana aparece como impotente. Nem a ação humana, nem sua vontade ou livre arbítrio podem impor limites à ação de Satanás. O demônio tem poder sobre a vida dos homens, sendo capaz de decidir os caminhos de cada um, sem lhes deixar praticamente opção de escolha. Por esse motivo o Demônio é uma figura que assusta os carismáticos. Ele é onipotente, tem poder sobre a vida dos homens, manipula-os a revelia de sua vontade e de forma muitas vezes imperceptível e banal. Ele age como uma bactéria, por infecção e essa contaminação independe da vontade humana. Nesse sentido, “as pessoas sentem-se vítimas de forças que são totalmente incapazes de controlar” (Nogueira, 2000:49).

O Demônio aparece, pois, como elemento que substitui a responsabilidade humana, tornando-se ele mesmo a causa dos malefícios, relacionados ou não à ação humana. Sob esse aspecto, todos os males são atribuídos a Satanás, independente da vontade ou escolha humana. Na IURD "não existe a idéia do mal escolhido ou não escolhido (...), um indivíduo não escolhe o mal, mas é possuído por este” (Mariz, 1996:56). Nesse sentido, o diabo exime o homem de poder e responsabilidade sobre suas ações, nas palavras de Gomes "ao miserável homem não se atribui responsabilidade ou culpa cosmológicas, como no cristianismo, segundo o qual herdamos a culpa de nossos pais, Adão e Eva. Praticamente ninguém tem culpa - nem Deus nem os homens - a não ser os Demônios.” (229:1994).

Essa concepção onipotente das forças malignas, comum a RCC e a IURD, reduz a condição humana ao papel secundário. Os homens não são responsáveis por suas escolhas, eles são agentes apenas por que realizam as ações, porém, essas ações são manipuladas por Satanás, sendo ele seu real autor.

Já nas aparições de Nossa Senhora, embora a presença do “inimigo” seja constante nas falas dos participantes, os males e sofrimentos que afligem a humanidade são, em grande parte, responsabilidade humana. Maria não exime seus filhos de culpa pelo seu destino. Eles não são manipulados ou infectados por Satanás - o demônio pode “tentá-los”, levá-los a cometer os pecados, porém, o homem tem sempre a opção da escolha, entre o “caminho do mal ou o caminho do bem”. Na explicação das aparições pelos participantes, Nossa Senhora vem avisar aos homens de que devem escolher uma vida sem pecados, dizer não para Satanás e sim para Deus. Assim, os homens são percebidos como responsáveis por seus destinos e escolhas. 
Sob esse aspecto, nas aparições de Jacareí - nas falas da Virgem, do vidente, dos peregrinos - a humanidade tem sempre um papel ativo. Nossa Senhora - que também é humana -, o vidente, os devotos e os peregrinos: todos são responsáveis por suas ações, todos têm papel ativo na história da salvação. Maria é a líder do exército, mas os homens são os guerreiros, os combatentes deste exército, os responsáveis pela sua própria vitória contra o pecado.

Dessa forma, embora a gama de pecados e a concepção da presença constante do "inimigo" no mundo seja semelhante à presente na RCC e no neopentecostalismo, nas falas das aparições os homens são percebidos como responsáveis por suas ações e figuras centrais na história da salvação: pela sua opção de vida - entre o pecado ou não - e por desempenharem o papel de guerreiros responsáveis, inclusive, pela conversão e salvação de outras almas. É, pois, o comportamento dos indivíduos que determinará o final dos tempos e o seu futuro entre a condenação e a salvação eternas.

Assim, na concepção dos participantes, embora Satanás esteja à solta pelo mundo, desencadeando todos os pecados mencionados, o homem não é isento de culpa. Os homens são dotados de livre arbítrio, podendo optar pelo “mundo” considerado repleto de pecados e por isso próximo do fim - o que implica em uma auto-condenação, pois esta opção os levaria a padecer todos os suplícios previstos para os pecadores no Juízo Final - ou em atender aos pedidos da Virgem, tornando-se guerreiros do exército de Maria - por meio da oração e do abandono do pecado.

Apesar do enfoque no pessimismo, no terror dos castigos, cada indivíduo é considerado único e responsável por suas escolhas. Percebemos que há uma concepção de indivíduo autônomo, livre e responsável por suas escolhas nos sentidos atribuídos à simbologia escatológica das aparições contemporâneas. Em seus termos, o mundo está repleto de pecados, mas os indivíduos são livres e responsáveis por suas escolhas.

A valorização do indivíduo foi percebida, ao longo de todo o capítulo, nos sentidos atribuídos à simbologia mariana e aos elementos escatológicos. Desde a maternidade de Maria, que tem um olhar especial para cada um deles, ela "conhece" cada um de seus filhos, eles são únicos diante de sua "mãe celeste"; os devotos se sentem amados por ela, que possui um amor exclusivo e especial por cada um deles.

Essa valorização torna-se ainda maior pela concepção dos homens como importantes guerreiros de Nossa Senhora, responsáveis pelo combate ao pecado por meio da disseminação das mensagens de Maria. Assim, além de únicos e amados, os 
homens também têm um papel ativo, eles são responsáveis por seu próprio destino e também pelo destino de outros homens. Eles são responsáveis por suas próprias vidas e escolhas - optando pelo pecado ou não - e também colaboradores na batalha de Maria, em busca da “conversão dos pecadores”.

Os elementos simbólicos analisados, além de valorizarem o indivíduo, também ampliam a sua dignidade, atribuindo-lhe responsabilidades; pois cada qual é percebido como responsável por suas ações e pelo seu destino, e, além disso, é um importante "guerreiro", podendo contribuir para a salvação da humanidade.

Assim, os homens são conduzidos por Maria, mas também estão ao seu lado na guerra, essa concepção demonstra a importância do lugar ocupado pelos indivíduos na história da salvação - da salvação individual, pelo abandono do pecado, e da salvação de outros homens, pela divulgação das mensagens da Virgem. O lugar dos homens, ao lado de Maria, e o papel desempenhado por eles, de contribuição para a história da salvação, são semelhantes aos desempenhados pela própria Virgem, que é concebida estando ao lado de Deus e possuindo um papel ativo na história da salvação.

Neste ponto, devemos lembrar que a ideologia individualista é a marca da modernidade. Segundo Louis Dumont, em seu clássico estudo sobre o individualismo, “a ideologia moderna é individualista. Trata-se de uma configuração, e não de um traço isolado" (2006:21). Dessa forma, a ideologia individualista é produtora e expressão da modernidade em suas diferentes manifestações e contextos.

Assim, sendo o individualismo a configuração da sociedade contemporânea, os sentidos dos elementos simbólicos presentes nas aparições de Nossa Senhora, ao atribuírem valor e responsabilidade ao indivíduo, estão em sintonia com este contexto.

Além disso, por meio da condenação do “mundo”, pela concepção de que “o mundo está repleto de pecados” há uma crítica da sociedade contemporânea. A maioria das pessoas está errada - pois optou pelo pecado - apenas os adeptos estão “corretos”, no “caminho do bem”. No entanto, essa crítica é ampla e vaga. Ampla devido a enorme gama de fatos considerados pecaminosos. Vaga por que os adeptos não se detêm nas características do pecado, mas sim na sua presença constante no “mundo”.

Dessa forma, a “escolha pelo bem” também estabelece uma valorização dos peregrinos em relação aos demais indivíduos, ao restante da sociedade. Por meio dos elementos simbólicos acionados nas aparições eles se percebem como pessoas especiais, como pessoas de força e coragem. Ou seja, os peregrinos se percebem como ocupando 
um espaço - são únicos e amados por Maria - e desempenhando um papel - são guerreiros da Virgem. 


\section{Considerações Finais}

Após esta longa análise das aparições marianas contemporâneas no Brasil, a partir do estudo de caso das aparições de Jacareí, podemos nos perguntar o que ele acrescenta aos debates sobre a religião ou a religiosidade.

Nossa análise foi encaminhada para o agir religioso, e por isso deixamos de lado o concepção da religião, inspirada no modelo weberiano, como um conjunto de dogmas e crenças, cuja adesão do fiel é central - seja esta adesão de tipo internalizada e racionalizada, ou de tipo tradicional e herdada. Isso porque a figura central de nosso trabalho não foi o fiel, no sentido clássico de adepto de uma religião, mas o peregrino. Entretanto, não se trata também da figura do "novo” peregrino como o indivíduo autônomo que circula entre uma série de “ofertas” ou “experiências” religiosas, sem aderir a nenhuma delas.

O peregrino das aparições marianas circula. Observamos a existência de uma rede de manifestações de Nossa Senhora, pela qual circulam pessoas, informações, símbolos e práticas; sendo que o indivíduo que circula por esta rede - ampla e desterritorializada - está também inserido em redes menos amplas de relações religiosas locais - paroquiais, de vizinhança e de parentesco. Ambas se mostraram centrais para que os peregrinos realizassem a peregrinação, demonstrando que a sua inserção nas redes de relações é fundamental, pois, o agir religioso de peregrinar depende dos contatos estabelecidos e as informações recebidas.

No entanto, contatos e informações não são suficientes para explicar a peregrinação. Essa prática é ressignificada pelos peregrinos. Não se trata mais do cumprimento de uma promessa para um santo, em que reciprocidade é central e o sacrifício importantes. Na peregrinação para as aparições os peregrinos percebem valores e características constituintes da contemporaneidade - valores que são importantes para os indivíduos na atualidade e características que se adaptam a seu modo de vida. Não se trata, pois, de um arcaísmo, mas de uma releitura atual de uma prática muito antiga. O exemplo de João Paulo II como “Papa peregrino” é emblemático. Mostramos o papel da constituição da crença em Nossa Senhora ao longo de sua vida, sendo ele próprio um devoto. Porém, ele também inova ao desterritorializar a peregrinação, enfatizando o sentido da circulação do sagrado e da Igreja pelo mundo. O peregrino é, na verdade, um novo personagem cujas características emergem quando durante as celebrações são acionados os repertórios simbólicos relativos à Virgem. 
A complexa relação entre elementos de longa duração e sua ressignificação contemporânea percorreu todo o nosso trabalho, não apenas em relação à peregrinação. Procuramos demonstrar que em todos os planos, desde o teológico até o da prática, elementos de tempos históricos distintos se articulam em um mesmo evento. Desse modo, a análise simbólica aqui empreendida procurou demonstrar que os sentidos do agir religioso não estavam inteiramente contidos nos atores e categorias acionados, ou na prática ritual, mas na justaposição e na relação de elementos heteróclitos, colocados em conjunção na rede. O próprio processo de circulação de idéias e atores que a rede promove, acaba por articular e conjugar fragmentos de origens diversas - teológica, memorialista, biográfica, jurídica - produzindo novas significações. No caso da simbologia mariana foi interessante perceber a atribuição de valor, responsabilidade e liberdade de escolha para os indivíduos.

A importância do movimento carismático neste processo se destacou ao longo de todo o trabalho. Ela representa o mais importante nó desta rede de aparições marianas, sendo em grande parte responsável pela organização das aparições; pela disseminação de informações, idéias e devoções e pela modelagem das aparições.

A organização hierárquica e burocrática da RCC, bem como sua presença reticular na Igreja - estando presente em paróquias de todo o país - possibilita que as idéias e crenças que servem de fonte de legitimidade para as aparições - principalmente produzida nos altos escalões da Igreja Católica - circulem e sejam disseminadas. Além disso, a sua organização reticular também contribui para a organização das peregrinações, permitindo que as informações sobre a realização de Cenáculos marianos e as crenças e devoções associadas a eles se disseminem de forma bastante eficiente.

Demonstramos também que o processo de modelagem das aparições, fundamental para a constituição da legitimidade dos eventos, é, em grande parte, realizado por membros do movimento, pois eles possuem o conhecimento necessário para estabelecer a aproximação dos fenômenos ao modelo - devido ao contato e circulação entre manifestações semelhantes.

A centralidade dos movimentos leigos, especialmente da RCC, na Igreja Católica pode, então, ser percebida. Podemos afirmar que a Instituição está presente nas aparições principalmente através da mediação do movimento carismático. Inclusive no que se refere às idéias e crenças produzidas sobre as aparições pelos representantes de seu alto escalão, os carismáticos são em grande parte responsáveis pela sua disseminação, colocando-as em circulação. 
Podemos afirmar que os movimentos leigos desempenham o importante papel de intermediários entre a Instituição e os indivíduos na religiosidade contemporânea. Essa intermediação foi notada ao longo de todo o trabalho - na organização das peregrinações, na disseminação de informações e na modelagem das aparições - mostrando-se fundamental para o sucesso das manifestações - desde a sua organização até a produção da veracidade da crença.

Nosso trabalho demonstrou, a partir da identificação da rede, os processos de mediação no mundo contemporâneo. Autores como Palard (2002), entre outros, apontam a mediação como evento chave das relações entre as instituições políticas e os indivíduos. Neste trabalho demonstramos que a mediação é um processo social constitutivo de práticas rituais e de sua legitimidade, produzindo a relação entre a experiência religiosa e a normatividade institucional católica. 


\section{BIBLIOGRAFIA}

Abbruzzese, Salvatore. Catholicisme et territoire: pour une entrée en matiére. In: Archives des sciences sociales des religions, no 107. Paris. 1999.

Albert-Lorca, M. Les apparitions et leur histoire. In: Archive des Sciences Sociales des religions. No 124. Paris, 2001. - Les Vierges Miraculeuses: legendes et rituels. Paris, Gallimard. 2002.

Almeida. Ronaldo. A guerra de possessões. In: Oro, Ari; Corten, André; e Dozon, Jean Pierre (orgs). Igreja universal do Reino de Deus. Os novos conquistadores da fé. São Paulo, Paulinas. 2003.

Almeida, Ronaldo. Dez anos do "chute na santa": a intolerância com a diferença. In: Gonçalves, Vagner (org). Intolerância Religiosa. São Paulo: Editora da Universidade de São Paulo, 2007.

Almeida, Tânia Mara. Vozes da Mãe do Silêncio. Brasília, CNPq/Pronex. 2004.

- A aparição de Nossa Senhora em Piedade dos Gerais. In: Steil, Carlos Alberto. Maria entre os vivos. Reflexões teóricas e etnográficas sobre aparições marianas no Brasil. Porto Alegre. UFRGS Editora. 2003.

As fadas de Piedade e as bruxas de Salem. In: Ciências Sociais e Religião. No 7. Porto Alegre. 2005.

Azzi, R. Catolicismo popular e autoridade eclesiástica na evolução histórica do Brasil. In: Religião e Sociedade. N 1, 1976.

Barnay, Sylvie. La Vierge: femme au visage divin. Paris, Gallimard. 2000. . “Le ciel sur la terre” Lês apparituions de la Vierge au moyen age. Paris, Gallimard. 2000.

Benedetti, L. R. Templo, Praça, Coração - a articulação do campo religioso Católico. São Paulo, FAPESP. 2000.

Beraud, Céline. Prêtes de la generation Jean-Paul II: recomposition de l'ideal sacerdotal et accomplissement de soi. In: Archives dês sciences sociales dês religions, no 133. Paris, 2006. 
Brandão, Carlos Rodrigues. Sacerdotes de Viola. Petrópolis, Vozes. 1986.

- Memória do Sagrado: Estudos de Religião e Ritual. Edições Paulinas, São Paulo. 1986. A Partilha da Vida. Petrópolis, Vozes. 1994.

Bouflet, Joachim et Boutry, Philippe. Un signe dasn le ciel: les apparitions de la Vierge. Paris, Bernard Grasset. 1997.

Bourdieu, Pierre. O Campo Religioso. In: A Economia das Trocas Simbólicas. São Paulo, Perspectiva. 1998

O poder simbólico. Rio de Janeiro, Bertrand Brasil. 1998.

Boutry, Phillipe. Rendre sés voeux. Paris, 2000.

Camargo, C. P. Católicos, Protestantes e Espíritas. Petrópolis, Vozes. 1973.

.Igreja e Desenvolvimento. São Paulo, Edições CEBRAP, 1971.

Campos,R.B.C. A Compadecida no Juazeiro do Norte: performance de imagens bíblicas e emoções entre os Ave de Jesus. In:Ilha, v4, no1. Florianópolis. 2002.

Camurça, Marcelo. As aparições da Virgem Maria em Mercês: sua vidente, apóstolos, romeiros e a Igreja Católica. In: Steil, Carlos Alberto. Maria entre os vivos. Reflexões teóricas e etnográficas sobre aparições marianas no Brasil. Porto Alegre, UFRGS Editora. 2003.

Cardoso, R. A Aventura Antropológica. Rio de Janeiro, Paz e Terra. 1986. Carranza, Brenda. Renovação Carismática Católica: Origens, Mudanças e Tendências. Aparecida, Santuário. 2000.

Claverie, Elisabeth. Lês guerres de la Vierge: une anthropologie dês apparituions. Paris, Gallimard. 2003.

Christian Jr. Willian. Visionaires: The spanish republic and the reign of christ. Los Angeles, University of California press. 1998.

Cremoux, Françoise. Pélerinages e miracles a Guadalupe au XVI Siécle. Madrid, Casa Velásquez. 2001.

Della Cava, Ralf. Milagre em Joaseiro. Rio de Janeiro, Paz e Terra. 1976.

Delumeau, Jean. Mille ans de bonheur: une histoire du Paradis. Paris, Fayard. 1995. 
Dumont, Louis. Essais sur l'individualisme. Paris, Essais. 1985.

Faustino, E. Renitente Catolicismo Popular. São Paulo. Tese de Doutorado. FFLCH/USP. 1996.

Ferreira, L.G. Igreja e Romanização: a Implantação da Diocese da Paraíba. Tese de Doutorado. São Paulo, USP. 1994.

Franco, Hilário. Ave, Eva! Inversão e Complementaridade de um mito medieval. São Paulo, Revista da USP, n 31. 1996.

A Eva Barbada. Ensaios sobre Mitologia Medieval . São Paulo, EDUSP. 1996.

Geertz, Clifford. A Interpretação das Culturas. Rio de Janeiro, JC Editora. 1989.

. O Saber Local. Petrópolis, Vozes. 1997.

. Nova Luz sobre a Antropologia. Rio de Janeiro, Jorge Zahar.

2001.

Gillet, Claude. La rumeur de Dieu: apparitions, propheties et miracles sous la restauration. Paris, Imago. 1994.

Giumbelli, Emerson. O fim da religião: dilemas da liberdade religiosa no Brasil e na França. São Paulo, Atar Editorial. 2002

Giumbelli, Emerson. Um projeto de cristianismo hegemônico. In: Gonçalves, Vagner (org). Intolerância Religiosa. São Paulo: Editora da Universidade de São Paulo, 2007.

Gomes, Wilson. Nem Anjos, Nem Demônios. Petrópolis, Vozes. 1994.

Harris, Ruth. Lourdes: la grande histoire dês apparittions, dês pèlerinages e des guérrisons. Paris, JC Lattès. 2001.

Harvey, David. A condição pós moderna. São Paulo, Edições Loyola. 1992.

Hervieu-Léger, D. Representam os Surtos Emocionais Contemporâneos o fim da Secularização ou o fim da Religião? In: Religião e Sociedade, Rio de Janeiro, ISER. v 18, n 1. 1997

. Le Pelerin et le Converti. La religion en mouvement. Paris, Flammarion, 1999.

. La modernité rituelle: rites politiques e religieux dês societés modernes. Paris, L’Harmattan. 2004. 
Hoonaert, E. Formação do Catolicismo Brasileiro. Petrópolis, Vozes. 1974.

. O Catolicismo Moreno do Brasil. Petrópolis, Vozes. 1989.

Kolakowski, L. O Diabo. In:Religião e Sociedade. Rio de Janeiro, ISER. N $12 / 2$

Lamy, Marielle. L'imacullé Concepcion. Etapes et enjeux d'une controverse au moyen age. Paris, IEA. 2000.

Leach, Edmund. Cultura e Comunicação: a Lógica pela qual os símbolos são ligados. Rio de Janeiro, Zahar. 1978..

. Cabelo Mágico. IN: Leach. São Paulo, Ática. 1983. . Nascimento Virgem. IN: Leach. São Paulo. Ática. 1983. . O Gênesis enquanto mito. IN: Leach. São Paulo, Ática. 1983.

Le Goff, Jacques. História e Memória. Campinas, Editora da Unicamp. 2003. . La naissance du purgatoire. Paris, Gallimard. 1981.

Levi-Strauss, Claude. O Feiticeiro e sua Magia. IN: Antropologia Estrutural. Rio de Janeiro, Tempo Brasileiro. 1996.

- A Eficácia Simbólica. IN: Antropologia Estrutural. Rio de Janeiro, Tempo Brasileiro. 1996.

Lewgoy, B. Os Espíritas e as Letras. São Paulo, Tese de Doutorado, FFLCH/USP. 2000.

Mariano, Ricardo. Igreja Universal do Reino de Deus: A Magia Institucionalizada. São Paulo, Revista da USP; Nº31. 1996.

Mariano, Ricardo. Neopentecostalismo. Sociologia do novo Pentecostalismo no Brasil. São Paulo. Edições Loyola. 1999.

Maués, Raimundo Heraldo. "Bailando com o Senhor: Técnicas corporais de culto e louvor. In: Revista de Antropologia, v 46, no 1. São Paulo, 2003. Machado, Maria das Dores Campos. Carismáticos e Pentecostais: Adesão Religiosa e seus Efeitos na Esfera Privada. São Paulo: FAPESP, 1996.

Magnani, J. G. C. Mystica Urbe: um estudo antropológico sobre o circuito neoesoterico na metrópole. São Paulo, Studio Nobel. 1999.

Magnani, J. G. C. Na Metrópole. São Paulo, EDUSP. 1996

Magnani, J.G C. Festa no Pedaço. São Paulo, Hucitec/UNESP. 1998 
Mariz, Cecília. O Demônio e os Pentecostais no Brasil. In: O mal à Brasileira. Rio de Janeiro, UERJ. 1997.

- Aparições da Virgem e o Fim do Milênio. In: Ciências Sociais e Religião. Porto Alegre, ano 4, no 4, Outubro de 2002.

- Comunidades de Vida no Espírito Santo: Juventude e Religião. In: Tempo Social, revista de sociologia da USP, v. 17, no 2. 2003.

Mariz, Cecília. Rainha dos anjos: a aparição de Nossa Senhora em Itaipu, Niterói. In: Steil, Carlos Alberto. Maria entre os vivos: Reflexões teóricas e etnográficas sobre aparições marianas no Brasil. Porto alegre, Editora UFRGS. 2003.

Megale, N. Invocações da Virgem Maria no Brasil. Petrópolis, Vozes. 1997.

Menezes, Renata de Castro. O sagrado, o convento e a cidade.

Montero, Paula. Magia e Pensamento Mágico. São Paulo, Ática. 19...

As Celebrações do V Centenário do Descobrimento da América. Petrópolis, Vozes. 1996.

- Igreja Católica diante da Modernidade. IN: Paiva, V.

Catolicismo, Educação e Ciência. São Paulo,Loyola. 1991.

. Cultura e Democracia no Processo da Globalização. In:

Revista Novos Estudos, no 44. São Paulo. 1996.

Montes, Maria Lúcia. As Figuras do Sagrado: Entre o Público e o Privado. In: História da Vida Privada IV. 1995.

Moura, M. M. Devoções Marianas na Roça e na Vila. Cadernos CERU. Série 2, n 8. 1997.

Nogueira, C.R. Diabo no Imaginário Cristão. São Paulo, EDUSC. 2000.

Oro, Ari Pedro. Avanço Pentecostal, Reação Católica. Petrópolis, Vozes, 1996.

Pallard, Jacques. Les recompositions territoriales de l'eglise catholique entre singularité et universalité. In: Archives de sciences socieles dês religions, no 107. Paris. 1999.

Pallard, Jacques. Mediation et instituition catholique. In: Archives de sciences sociales des religions, no 133. Paris, 2006.

Peirano, Mariza. A Favor da Etnografia. Rio de Janeiro. Relume Dumará. 
Pelletier, Denis. Regards sur une fin annoncée. In: Archives de sciences socielle des religions, no 126. Paris. 2004 . La crise catholique. Paris, Payot. 2005.

Pelikan, Jaroslav. Maria através dos séculos. São Paulo, Companhia das Letras. 2000.

Pierucci, AF. Igreja Católica 1945/1970. IN: Fausto, b. História Geral da Civilização Brasileira. Rio de Janeiro, Bertrand Brasil. 1995. - Realidade Social das Religiões no Brasil. São Paulo, Hucitec. 1996.

Portier, Philippe. La pensée de Jean-Paul II. Paris, Les Editions de l'atelier. 2006.

Prandi, R. Um Sopro do Espírito. São Paulo. EDUSP. 1997.

Sanabria-Sanches, F. Lês apparitions contemporaines de la Vierge em Amerique Latine. Tese de doutorado. Paris, EHESS. 2004.

Sales, Lílian. Família e Moralidade entre as Mulheres da Renovação Carismática Católica. Campinas. Relatório de Bolsa de AperfeiçoamentoCNPq. 1998.

Sales, Lílian. “Ou quente, ou frio, senão vomitar-te-ei”: um estudo das práticas rituais da Renovação Carismática Católica. Dissertação de Mestrado. São Paulo: FFLCH/USP. 2003.

Sanchis, Pierre. Pentecostalismo e cultura brasileira. In: Religião e sociedade, vol 18, no 02. Rio de Janeiro. 1997.

Sanchis, Pierre. Identidade Católica. Comunicações ISER., N²2. 1983.

Silva, Vagner. Intolerância religiosa: impactos do neopentecostalismo no campo religioso afro-brasileiro. São Paulo, Edusp. 2007.

Souza, André. Padres Cantores, Missas Dançantes. Dissertação de Mestrado. FFLCH/USP. 2001

Souza, L. M. O Diabo e a Terra de Santa Cruz. São Paulo, Cia das Letras. 1986.

Steil, Carlos Alberto. O sertão das Romarias: Um estudo Antropológico sobre o Santuário de Bom Jesus da Lapa, Bahia. São Paulo, Vozes. 1996. . Maria entre os Vivos. Porto Alegre, Editora da UFRGS. 2003. - Uma antropologia das peregrinações e do turismo religioso, algumas questões metodológicas. Imaginário - USP, no 8. 2002. 
- Romeiros e Turistas no Santuário de Bom Jesus da Lapa. In:

Horizontes Antropológicos. V 9, no 20. Porto Alegre. 2003

- As aparições marianas na história recente do catolicismo. Porto Alegre, Editora UFRGS. 2003.

Turner, Victor. O processo ritual: estrutura e antiestrutura. Petrópolis, Vozes. 1974.

Zaluar, Alba. Os Homens de Deus. 1983.

Warner, Marina. Alone off all her sex: The Myth and the Cult of Virgin Mary. New York, Vintage. 1983.

Weber, Max Economia y Sociedad. Mexico, Fondo de cultura economica. 1997. 


\section{Documentos e Fontes Bibliográficas Primárias}

Anônimo. As aparições de Nossa Senhora em Jacareí. Jacareí. 2000. . Documentação crítica de Fátima: Interrogatórios aos videntes. . Histoire anciene et histoire nouvelle de Fátima. . Les apparitions de la mére de Dieu dans l’ortodoxie.

Bettega, Victor. Iconographie de Notre Dame de La Salette.

Billet, Bernard. Le fait des apparitions non reconnues par l'église.

Bouflet, Joachim. Medjugorje ou la fabrication du surnaturel. Paris, Salvador. 1999.

Dierkens, A. Apparitions et miracles. Bruxeles, EUB. 1991.

Gasnier, Michael. Rosaire et apparitions marieles.

Laurentin, René. Dictionnaire des miracles. Paris, Fayard. 2002. . Memoires: chemin vers la lumiére. Paris, Fayard. 2005. . La medaille miraculeuse. Documents autentiques. Paris, 1976. . Lourdes, documents autentiques. Paris, 1966. . Court traité de theologie mariele. . Crise du miracle. . Medjugorje a l'heure de la desinformation. . Vrais et fausses apparitions dans l'église. . Pontmain: histoire autentique. . La crise du miracle. . Medjugorje: à l'heure de la desinformation.

Martins, Antônio. Fátima et lê coeur de Marie.

Stern, Jean. La Salette. Documents autentiques. 